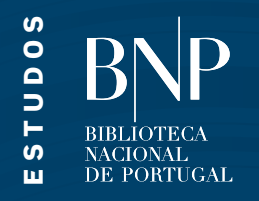

\title{
O outro nome de «Don Estevan» OITO SÁTIRAS TROVADORESCAS RELACIONADAS COM SANCHO II DE PORTUGAL Ângela Correia
}

Nhal disse don auras soga A bra uelha nontio dia Disselbi pero soarez hum messa perderizia, Won uptala bo batreró srandit confuswo furum Troufoy socpro bezerma Al ravere de celorico

Salmos son os Jruedores, enant' os rusfelly deró

super igné ctermix Et dummitatis opem Saluo e gur Trae caftelo A piore go ysopen

Don efferom diz ýde somor A ró el kay esey eu cal mentr (I) murica myu prazer poys foy agm () Conde no vera muereli for

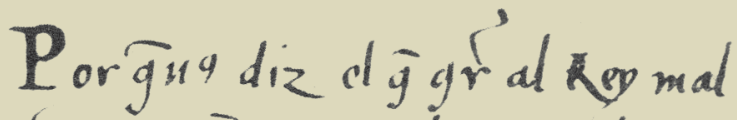
(a ren nō uce asso de mi pardon Q hee el maps ampno seu coragon Né necra mica ed direyng al

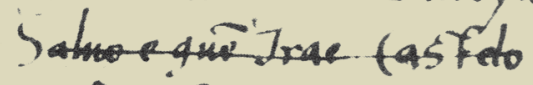
A 90.

Eoys g̈ssugrora o Reyno pmen

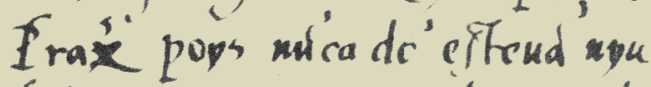
Wen Veera ia maves of tertunal

F

A ernomu diaz caymi romo viffers Eand a é prearo desse' asar trtays non pado cusamíto rhegar

Deme o sey en $g$ sabe come E por aupr rasamerta lafe Dume múra nos ta' grá ropera misfor

Eporendanda nesfide loxsane $\varepsilon$ diz 9 mowe i out molher, mans offe rasommento âd yr Domo o suy en glho no dara 





\section{O outro nome de «Don Estevan»}

OITO SÁTIRAS TROVADORESCAS

RELACIONADAS COM SANCHO II DE PORTUGAL

Ângela Correia 
O outro nome de «Don Estevan»

Oito sátiras trovadorescas

relacionadas com Sancho II de Portugal

\section{AUTORA}

Ângela Correia

CAPA

Cancioneiro da Biblioteca Nacional. [1525-1526] COD. 10991, f. 310v, pormenor.

\section{DESIGN}

TVM Designers

PRÉ-IMPRESSÃO

Serviço de Atividades Culturais BNP

IMPRESSÃO E ACABAMENTO

ACDPrint

Julho 2021

DEPÓSITO LEGAL

486749/21

DOI

$10.51427 / 10451 / 49253$

TIRAGEM

150 exemplares

(C) Biblioteca Nacional de Portugal e autora, 2021
BIBLIOTECA NACIONAL DE PORTUGAL CATALOGAÇÃO NA PUBLICAÇÃO

CORREIA, Ângela, 1967-

O outro nome de «Don Estevan» : oito sátiras trovadorescas relacionadas com Sancho II de Portugal. - Lisboa : Biblioteca Nacional de Portugal, 2021. - 190 p. - (Estudos)

ISBN 978-972-565-688-4 (ed. impressa)

ISBN 978-972-565-689-1 (ed. eletrónica)

CDU 821.134.3-1"11".09

APOIOS

(2) Centro de Linguística

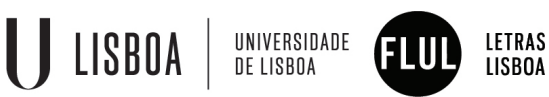

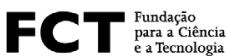

o Centro de Linguística da Universidade de Lisboa é financiado por fundos nacionais através da FCT - Fundação para a Ciência e a Tecnologia, I.P., no âmbito do projeto UIDB/00214/2020. 
Introdução

Textos: edição crítica e interpretação 23

Um retrato que retrata quem o fez 131

$\begin{array}{ll}\text { Enquadramento histórico } & 137\end{array}$

$\begin{array}{ll}\text { Estêvão Soares, arcebispo de Braga } & 138\end{array}$

Mestre Silvestre Godinho, arcebispo de Braga $\quad 146$

Joam Viegas de Portocarreiro, arcebispo de Braga $\quad 147$

$\begin{array}{ll}\text { As cidades } & 152\end{array}$

A deposição de Sancho II de Portugal 155

$\begin{array}{ll}\text { Os trovadores } & 163\end{array}$

Interpretações recentes $\quad 169$

$\begin{array}{ll}\text { A identificação } & 169\end{array}$

$\begin{array}{ll}\text { A razão da sátira } & 171\end{array}$

$\begin{array}{ll}\text { Local e datação da sátira } & 175\end{array}$

$\begin{array}{lr}\text { Algumas conclusões } & 179\end{array}$

$\begin{array}{ll}\text { Bibliografia } & 182\end{array}$

$\begin{array}{ll}\text { Índice das sátiras editadas } & 188\end{array}$ 

Para N. 



\section{Introdução}

Estêvão Soares e Estevainha Soares foram ambos filhos de Soeiro Pires, cuja alcunha - Torto (cego de um olho) - terá servido também, como era costume, para identificar os filhos. Estevainha casou com um Riba de Vizela e o casal foi escolhido por Afonso II para criar o futuro rei, Sancho II. Mas a influência de Estevainha e do marido sobre Afonso II teve ainda outra via, uma vez que uma das filhas do casal se tornou amante do Rei.

Não terá sido alheia a esta proximidade a eleição do irmão de Estevainha Estêvão Soares, mestre-escola em Coimbra - para arcebispo de Braga. A eleição era feita pelo cabido, mas fortemente condicionada pelo Rei. Não será por isso de espantar que D. Estêvão Soares sofra inicial contestação, mas rapidamente agarra o lugar e faz caminho diplomático em Roma, junto do Papa, e até noutros reinos, somando prestígio e riqueza. A morte do marido de Estevainha, quando Sancho conta apenas dois anos, deixa o príncipe sem amo e a irmã de D. Estêvão sozinha à frente da casa de família. É provável que o Arcebispo assuma então as funções educativas que o aio do príncipe já não poderia desempenhar, o que explicaria os muitos favores que dele receberá no futuro, e a paz que, apesar de todos os acontecimentos, nunca vacilou entre os dois.

É também atribuída ao poderoso arcebispo de Braga, D. Estêvão Soares, a criação de outro menino especial: Gonçalo, que será mais tarde conhecido por São Gonçalo de Amarante. Terá sido o Arcebispo a torná-lo abade e a atribuir-lhe a igreja de S. Paio de Riba de Vizela, bem como os respetivos rendimentos. A ter de facto existido esta criança, ter-se-á cruzado com o príncipe na casa do amo? Terão chegado a desenvolver laços de colacia? Provavelmente nunca chegaremos a saber, mas ambos partilharão o destino de serem traídos e expulsos por pessoas que beneficiaram e em quem confiaram. E este destino comum talvez não tenha passado despercebido aos trovadores.

Empenhado em limitar o avanço dos privilégios do clero, Afonso II ordena as Inquirições de 1220. Mas D. Estêvão, que já apoiara a causa das irmãs do Rei contra o monarca, defende a independência clerical e, escudado por igual conceção papal de extensa separação de poderes, enfrenta o Rei e excomunga-o. A Afonso II, não lhe vale, portanto, o apoio dado ao Arcebispo para a eleição, nem que este pertença à família de pessoas do seu círculo mais próximo, da sua domesticidade. D. Estêvão não lhe reserva nenhuma lealdade, chegando a acusar Afonso II de comportamento imoral por ser adúltero; com a sua sobrinha, 
recorde-se. O Rei enfurece-se, dando início a ações armadas contra as propriedades do Arcebispo, e D. Estêvão é então forçado a exilar-se em Roma, até que, já à beira da morte, Afonso II concorda com a paz. Morre, no entanto, deixando para o filho Sancho a tarefa de estabelecer os termos exatos da reparação e da concórdia, que acabarão por ser singularmente generosos para o Arcebispo. Sancho cede-lhe uma enorme fortuna, além de ter com ele mantido longa paz, mesmo quando razões haveria para conflito.

Extremamente influente, prestigiado e rico, D. Estêvão foi arcebispo de Braga durante 15 anos (de 1213 a 1228), durante os quais enfrentou Afonso II e dobrou Sancho II; venceu a contestação do muito prestigiado arcebispo de Toledo, D. Rodrigo Ximenes, que contestou o estatuto de Braga como igreja primaz de Espanha; foi legado da Sé Apostólica e mediador no acordo de Boronal, entre a coroa de Portugal e a de Leão, que lhe valeu a doação do couto de Ervededo. Em suma, acumulou fama de capacidade diplomática e negocial, nacional e internacional, sendo um símbolo de poder, riqueza e capacidade política.

Sucede a D. Estêvão Soares, no arcebispado de Braga, mestre Silvestre Godinho, a cujo conhecimento jurídico e diplomacia se deve um relacionamento essencialmente pacífico com a coroa. Viveu em Roma desde 1241 até à morte, em 1244, anos em que a situação social e política em Portugal atingiu um alto grau de deterioração.

Em 1236, o afastamento de mestre Vicente do comando da chancelaria dá início ao declínio da situação do reino e da respetiva governação, que terminará com a deposição de Sancho II. A justiça deixou de ser aplicada, pelo que a violência e a insegurança generalizadas foram alastrando, especialmente fora das cidades, mas, por fim, também dentro delas. O Rei foi perdendo apoios e foi-se encontrando cada vez mais desamparado no exercício do poder, cada vez mais isolado, política e até pessoalmente.

Em 1244, Sancho II não podia dar-se ao luxo de não controlar a eleição do arcebispo de Braga, na tentativa de manter, naquele importantíssimo lugar, um amparo à sua fragilizada governação. Sabemos que tentou, sem sucesso, assegurar a fidelidade do bispo de Porto com doações. E sabemos que, cerca de uma década antes, tinha constrangido o cabido a eleger o sucessor do bispo de Lisboa, D. Soeiro. Não é verosímil que, naquela conturbada véspera da deposição, deixasse passar a eleição do arcebispo de Braga sem a influenciar, pelo que a escolha de Joam Viegas de Portocarreiro, arcediago em Braga, resulta certamente de pressões feitas pelo Rei na expetativa de fidelidade e apoio. A comparação com um diplomata da família dos Sousa, como D. Estêvão Soares, ou com um afamado jurista, como mestre Silvestre Godinho, não seria favorável ao filho de uma família de nobreza secundária como 
os Portocarreiro. Mas Sancho II talvez tenha esperado que, até por isso mesmo, a dívida de gratidão melhor garantisse a lealdade. Enganou-se, porém.

Tal como a eleição de D. Estêvão, a de Joam Viegas foi inicialmente contestada, mas, ao contrário do sucedido com D. Estêvão, que rapidamente ultrapassou as contestações, Joam Viegas nunca conseguiu impor a sua autoridade, tendo o Papa tido de o socorrer repetidamente para que pudesse fazer valer os seus direitos na hierarquia clerical. Na verdade, não só repetidamente, mas também prolongadamente, já que, segundo a documentação, dez anos depois da eleição, o Papa ainda teve de enviar prelados, hierarquicamente inferiores a Joam Viegas, em auxílio deste na resolução de conflitos com clérigos. Talvez não haja maior sinal de incapacidade e inabilidade do novo Arcebispo.

O trovador Joam Soares Coelho deixara Castela ao serviço do infante Fernando de Serpa, irmão mais novo de Sancho II e do futuro Afonso III, em 1243, rumo a Portugal. Antes desta partida, provocara uma discussão literária com uma inovação consistindo na tradução para latim (Ama) de uma alcunha de mulher (Mocha), que usa numa cantiga de amor e, depois, numa segunda. Criticam-no pelo equívoco que podia originar tal tradução, envolvendo uma mulher da mais alta nobreza: Urraca Guterres Mocha, da família dos Meneses.

O infante Fernando de Serpa, de quem Joam Soares Coelho é vassalo, chegou a ser o mais próximo aliado familiar de Sancho II e o seu braço armado contra a Igreja, mas em 1239 encaminha-se para a cúria papal onde mostra arrependimento, aceita as penitências que o Papa lhe prescreve e torna-se vassalo da Santa Sé. A partir de então, Sancho II nunca mais contará com ele. Por ordem do Papa, Fernando passa por Castela para combater os mouros ao lado de Alfonso de Molina, irmão de Fernando de Castela e Leão, mas, em 1243, já está de regresso a Portugal. Aqui, mantém-se próximo da nobreza que apoia o conde de Bolonha, futuro Afonso III, mas intermitentemente assume a tenência de Tarouca. Por esta razão, e pela proximidade familiar ao Rei, é natural que frequente a corte com o seu séquito de vassalos e conselheiros. Joam Soares Coelho está entre estes.

Terá sido na corte, ainda antes da deposição de um Rei já muito fragilizado, que Joam Soares Coelho apresentou a primeira cantiga do conjunto satírico contra uma figura que trata por «Don Estevan». Mas este não deverá ser o nome do visado, nem o visado deverá ser o único visado, neste primeiro escárnio político. Coelho desenvolve, nesta cantiga, mais um exercício de substituição de um nome por outro nome; neste caso, no contexto de uma cantiga de escárnio e com uma lógica totalmente diferente da que presidiu ao exercício das duas cantigas em louvor da Ama. Ainda assim, o mesmo exercício literário. 
Em Don Estevan, que thi non gradecedes, Joam Soares Coelho começa por descrever a incapacidade de entendimento e de adaptação do visado a um contexto diplomaticamente exigente, como o da corte. Propõe dois remédios para tão desastrosa situação social: que use nome mais adequado ( $\ll$ d'averdes nome muito vos jaz») e que se faça acompanhar de alguém competente, capaz de o orientar ( «nunca de vós devedes a partir un ome que vos trag'acompanhado»).

O nome pelo qual o trata - «Don Estevan» - é já a máscara que lhe estende, o tal nome mais adequado por ter sido o nome de alguém que, com competência e prestígio, ocupou a mesma posição ocupada agora com toda a incompetência pelo visado. Será este o nome capaz de transmitir a ilusão de que aquele que o usa tem as qualidades necessárias e suficientes para ocupar o lugar para o qual foi eleito, e comportar-se à altura dele. Mas o comportamento em contexto de corte («pois per cort'avedes a guarir») exigirá apoio complementar ao nome e, por isso, se recomenda também companhia capaz de ajudar ( «nunca de vós devedes a partir un ome que vos trag'acompanhado»). Eventualmente alguém como o capelão, que também se chamava Estêvão: coincidência de nomes que talvez tenha sido fonte suplementar de riso.

Joam Viegas de Portocarreiro é o visado cujo nome Joam Soares Coelho troca pelo nome do antigo arcebispo D. Estêvão Soares, considerando que, para ter sido escolhido pelo Rei, deveria ser necessário ter um nome como o de D. Estêvão e, para andar pela corte sabendo nela comportar-se, seria necessário saber mais do que Joam Viegas.

Renomeado, Joam Viegas já poderia considerar-se digno da escolha do Rei; devidamente apoiado no conhecimento de dependentes que o orientassem, já poderia andar pela corte. De resto, a escolha do nome de «Don Estevan» para substituir o nome indigno da escolha do Rei tinha outra vantagem: o proprietário original do nome, Estêvão Soares, tinha também uma alcunha - Torto (meio cego) - perfeitamente adequada a descrever um homem incapaz de compreender verdadeiramente o que se passava à sua volta («os que vos veen que vós non veedes» = os que vos entendem e vós não entendeis).

Compondo pouco depois da eleição de Joam Viegas, no final de 1244, o trovador Joam Soares Coelho comenta, nesta cantiga, o desastre em comportamento que era a presença na corte do novo Arcebispo e, portanto, a lamentável escolha do Rei. Nos últimos meses de vida, antes de falecer, em 1246, Fernando de Serpa mantém-se próximo dos grupos da nobreza que contestavam o Rei. A sátira de Joam Soares Coelho, vassalo de Fernando de Serpa, não se esgota em Joam Viegas e no seu comportamento desastrado, 
atingindo igualmente, ou mesmo sobretudo, o Rei e a pobreza das escolhas que faz para lugares como os do arcebispado de Braga. Por outro lado, tal crítica às escolhas políticas de Sancho II, no ambiente da sua própria corte, é muito revelador da fraqueza do Rei, em vésperas da deposição. Mas o modo indireto, e portanto cuidadoso, da crítica a um Rei em queda é também revelador da reduzida amplitude satírica dos trovadores em relação ao poder real.

Ao contrário do que acontece com o exercício de substituição de nome nas cantigas de amor à Ama, neste caso, a proposta de Coelho, no contexto das cantigas de escárnio e maldizer, não sofre contestação. Pelo contrário, o recurso será adotado por outros trovadores, para desenvolvimento de mais cantigas do conjunto satírico contra «Don Estevan». Na verdade, não apenas neste conjunto satírico, já que na cantiga $A$ lealdade da Bezerra pela Beira muito anda, Airas Peres Vuitorom qualifica precisamente Joam Viegas de Portocarreiro com o adjetivo «torto», que é também a alcunha de D. Estêvão Soares, nome usado para o designar no conjunto satírico contra «Don Estevan». Na adoção da ideia criativa de Joam Soares Coelho há, no entanto, como veremos, algumas variações proporcionadas pelas circunstâncias, que não são atualmente percetíveis sem a devida ponderação.

O desenvolvimento do conjunto satírico não será imediato e voltará a depender de objetivos políticos. Assim como a cantiga de Joam Soares Coelho foi politicamente motivada pela crítica à escolha do Rei para o lugar do arcebispo de Braga, assim também outros trovadores voltarão a compor contra «Don Estevan», quando razões políticas os levarem a isso; não imediatamente, mas pouco depois. Eis uma diferença em relação à discussão literária em torno das cantigas à Ama que se desenrolaram, pelo menos na sua maioria, num curto espaço de tempo.

A composição do conjunto satírico contra «Don Estevan» dividir-se-á, depois da primeira cantiga, anterior à entrada do Conde em Portugal, em duas fases, com dois objetivos políticos diferentes, embora mantenham o visado.

Na primeira fase, a composição é provavelmente patrocinada por Alfonso, príncipe de Castela e Leão, futuro Alfonso X, e inscreve-se nos esforços de angariação de apoios para resistir à tomada do poder pelo Conde. Compreende-se pelas cantigas de Airas Peres Vuitorom e de Tenoiro que o Rei está ainda vivo e que o Conde já se encontra no reino. Este é um tempo de bipolarização: o reino divide-se entre os partidários do Rei e os do Conde; o espaço do Rei - Coimbra - e os do Conde - Leiria e Lisboa. O arcebispo Joam Viegas acompanha o Conde ameaçando de excomunhão todos os que não reconheçam a autoridade do novo governador de Portugal, todos os que auxiliem o Rei. O príncipe Alfonso de Castela vem em auxílio de Sancho II e, junto à fronteira, esforça-se por reunir apoios militares e financeiros, ao mesmo tempo 
que, por carta, procura influenciar no sentido de impedir que mais apoios se juntem ao Conde. Vuitorom e Tenoiro são trovadores de modesta nobreza que lhe são próximos e as cantigas que compõem inscrevem-se provavelmente na ação de propaganda cujo objetivo é favorecer boas-vontades para a causa real, quebrar a credibilidade do poderoso adversário clerical.

Na cantiga Don Estevan, eu eiri comi, Tenoiro aposta na esperança, fazendo um retrato de prosperidade, paz e segurança, simbolizado num mirífico jantar, que associa ao Rei, e de que exclui «Don Estevan», dividindo o mundo entre escolhidos e castigados, à boa maneira da propaganda política. Faz-se nela alusão explícita aos dez anos em que o reino esteve mergulhado em insegurança e carestia, sendo o jantar do Rei simultaneamente a promessa e a prova de que tal período terminou, assim como a confirmação de que é nas mãos do Rei que reside o poder de o conseguir.

Em janeiro de 1247, o príncipe Alfonso patrocina uma incursão militar em favor de Sancho II, na sequência da qual o pai, Fernando III, é excomungado pelo arcebispo Joam Viegas. Pouco depois, em março de 1247, Alfonso retira-se levando Sancho II para o exílio em Toledo, onde morrerá, no final de janeiro 1248. Mas talvez esta retirada tenha começado por ser pensada como temporária, uma vez que Vuitorom compõe, em Portugal, a cantiga Don Estevan diz que desamor, já depois da saída de Sancho II. E nela o esforço de descredibilização de Joam Viegas continua. $\mathrm{O}$ trovador ataca o Arcebispo acusando-o de ter traído o Rei por cupidez e de, ainda por cima, o ter feito estupidamente, uma vez que do Rei recebeu benefícios (a própria eleição) que nunca receberá do Conde. A estupidez, a incapacidade de perceção estratégica ou mesmo a incapacidade de perceção além do óbvio é um traço transversal nos retratos que os trovadores fazem de Joam Viegas. Mas, nas duas cantigas desta segunda fase, de Tenoiro e de Vuitorom, não é com o verbo «ver» que se refere o «entendimento» ou a falta dele, como o fizera Joam Soares Coelho na primeira cantiga, e voltará a fazer. O verbo «ver», nesta fase, tanto para Tenoiro quanto para Vuitorom, assume o sentido de «receber benefício».

$\mathrm{Na}$ verdade, ambos os trovadores evitarão sempre os jogos verbais de Coelho. Recordemos, a este propósito, que Coelho e Vuitorom discutem méritos no âmbito do debate em torno da Ama (Joan Soares, pero que vós teedes e Don Vuitoron, o que vos a vós deu) e que Coelho chega a declarar ter composto cantigas para Vuitorom apresentar como dele. A marcação da diferença, neste conjunto satírico, poderá portanto ser reveladora dos aspetos da criação em que os trovadores consideravam haver individualidade. De resto, a própria adoção da ideia de substituir o nome do arcebispo Joam Viegas pelo nome do arcebispo Estêvão Soares poderá, a partir das cantigas de Vuitorom 
e Tenoiro, assumir contornos que ainda não tinham na primeira cantiga de Coelho. A partir do momento em que avança o processo de deposição de Sancho II, Joam Viegas torna-se no beneficiado traidor, que D. Estêvão também fora. A substituição do nome deixa de funcionar apenas como a irónica máscara proposta por Coelho, que haveria de evidenciar o contraste entre a máxima competência e a total incompetência. Nas novas circunstâncias políticas, a máscara cola-se ao rosto do portador por afinidade moral: ambos os arcebispos tinham sido beneficiados na eleição pelos reis a que negam depois lealdade. Tenoiro e Vuitorom adotam a ideia criativa de Coelho, mas exploram-na de forma diferente, o que poderá constituir mesmo uma forma de afrontar Joam Soares Coelho. Na verdade, João Viegas era então um aliado do conde Afonso III e, portanto, deixara de ser do interesse de Coelho satirizá-lo. A adoção do recurso de Coelho, por Tenoiro e Vuitorom, será então menos uma homenagem ao trovador que um confronto, dada a mudança de ângulo. De resto, Tenoiro e Vuitorom, voltarão a fazer o mesmo esforço de diferenciação mais tarde, quando voltarem a compor contra «Don Estevan» e estiverem mais alinhados com os interesses de Coelho do que no primeiro momento. Nesta fase de desenvolvimento do conjunto satírico, Joam Soares Coelho abstém-se naturalmente de intervir.

A fase seguinte de composição contra o arcebispo de Braga decorre já após a morte de Sancho II no final de janeiro de 1248. Das cantigas desaparecem os sinais de bipolarização. Vive-se um tempo diferente, marcado por uma abrupta mudança de ordem, por um novo Rei com novos critérios de admissão nos círculos do poder. Ou seja, um tempo de oportunidades. Não será por acaso que os trovadores participantes neste conjunto satírico pertencem todos a círculos modestos da nobreza. Junta-se-lhes mais um - Roi Queimado - que apenas participa nesta última fase.

Tendo Sancho II já desaparecido, o interesse político de qualquer ataque ao arcebispo de Braga não será já o do Rei deposto. Resta o interesse político do novo Rei, que não é pequeno. Na verdade, Afonso III comprometera-se com o clero no Juramento de Paris sem restrições, para chegar ao poder. Mas lá chegado e herdada a coroa após a morte do irmão, Afonso III tinha todo o interesse em desembaraçar-se das pressões do clero, nomeadamente do arcebispo de Braga, que lhe exige o cumprimento das promessas feitas. $\mathrm{O}$ ataque político ao Arcebispo passa a ser do interesse do novo Rei, que também necessita de pacificar o reino, uni-lo em torno do seu comando; objetivo que poderá ter beneficiado de um inimigo comum.

Joam Soares Coelho começou de novo esta ronda com a cantiga Don Estevan fez sa partiçon, onde o verbo «ver» significa, de novo, «entender», e cuja inventio se reflete, embora de formas diferentes, nas restantes cantigas. 
$\mathrm{Na}$ verdade, mais do que começar, compondo, poderá mesmo tê-la organizado ao serviço do novo Rei, aliciando trovadores para o empreendimento.

Após a morte de Fernando de Serpa, em 1246, Joam Soares Coelho aproxima-se de Afonso III, de quem é já conselheiro, em novembro de 1248. Quando Sancho II morre, no final de janeiro de 1248, Coelho já não é, portanto, vassalo do irmão mais novo do Conde, que aspirava a uma aliança com o novo Rei de Portugal. O trovador, descendente por via bastarda de Egas Moniz, procura então saltar um elo na cadeia de vassalagem e conquistar um lugar na corte, ao serviço de Afonso III. Dois anos depois da morte de Fernando de Serpa, em 1246, já o conseguira.

Na cantiga Don Estevan fez sa partiçon, Joam Soares faz referência a uma situação espinhosa com a qual o Arcebispo não conseguiria lidar. As acusações de que Joam Viegas é incapaz de lidar com questões diplomaticamente delicadas são frequentes no conjunto satírico, mas, neste caso, o trovador acrescenta um topónimo que deveria ser esclarecedor para o público: Amarante. Considerando a datação destas cantigas e a da construção da ponte de Amarante, assim como o envolvimento do arcebispo de Braga (ou vários deles) na Vida de São Gonçalo de Amarante e o nome da igreja que lhe é atribuída pelo Arcebispo (S. Paio de Riba de Vizela), segundo a mesma Vida; considerando ainda que encontraremos alguns elementos narrativos da Vida em duas cantigas deste conjunto satírico, é possível que a referência a Amarante seja uma alusão a esta personagem hagiográfica.

As duas cantigas de Tenoiro e Vuitorom, compostas nesta última fase de desenvolvimento do conjunto satírico contra Joam Viegas de Portocarreiro, diferem em diversos aspetos das anteriormente compostas por estes trovadores e, na verdade, de todas as outras também. Mas esta diferença não admirará, se tivermos em consideração que, embora a orientação da sátira se mantenha - criticar Joam Viegas diminuindo-o socialmente - o objetivo político subjacente foi certamente outro. Embora Vuitorom e Tenoiro tenham sido, com provável patrocínio de Alfonso de Castela, acérrimos defensores de Sancho II, na segunda fase de composição destas cantigas; após a morte do Rei, na terceira fase, serviram o interesse político do novo Rei: Afonso III. Não foram de resto os únicos, uma vez que mesmo a nobreza que se manteve fiel a Sancho II até ao fim, mesmo a nobreza que o acompanhou até ao exílio acabou, após a morte do Rei, por ser integrada nos novos círculos do poder, ao serviço de Afonso III. Não deve, portanto, surpreender que Vuitorom e Tenoiro mantenham o ataque a Joam Viegas, desta vez ao serviço de Afonso III. Nem deve surpreender a diferença nestas duas composições, criadas em momento diferente e com objetivo político diverso. No retrato de Joam Viegas, que nelas se encontra, domina o traço da fúria, e o jogo com o verbo «catar», com diversos sentidos, substitui o jogo com o verbo «ver». 
Na cantiga Don Estevan achei noutro dia, de Tenoiro, por outro lado, «Don Estevan» é designado «torto», termo que serve também para referir Joam Viegas na cantiga A leadade da Bezerra pela Beira muito anda, de Vuitorom. Embora esteja presente a alcunha de D. Estêvão Soares - Torto (cego de um olho) - nesta qualificação, o sentido atribuído ao adjetivo, na cantiga, é «injusto». Também neste aspeto, Tenoiro parece esforçar-se pela diferenciação poética em relação a Coelho.

São estas duas cantigas que têm em comum com a Vida de São Gonçalo de Amarante dois elementos narrativos - a agressão com pau, e os cães -, o que poderá dialogar com a primeira cantiga desta fase de composição do conjunto, de Joam Soares Coelho. Nas três cantigas poderá, igualmente, aludir-se à história de S. Gonçalo para atingir Joam Viegas na reputação do seu caráter. Segundo a vida de $\mathrm{S}$. Gonçalo, este beneficiou um sobrinho entregando-lhe a sua igreja enquanto peregrinava. Ao regressar, descobre que o sobrinho the tinha usurpado a igreja, com a conivência do arcebispado, e é por ele escorraçado à paulada e sob a ameaça dos cães. Do mesmo modo, Sancho II beneficia Joam Viegas favorecendo-o na eleição para o arcebispado. No entanto, Joam Viegas é o protagonista na deposição do Rei. Em nenhuma das três cantigas se encontra um paralelo direto entre as duas histórias, nem sequer uma alusão direta à Vida de São Gonçalo que, caso a figura hagiográfica tenha existido, como tudo indica, não passaria então de relatos cujos contornos são hoje indefiníveis. Ainda assim, a alusão seria útil aos efeitos pretendidos com o retrato desenhado nas três composições, mesmo que este não se apoie nela.

Roi Queimado participa nesta fase final de composição com duas cantigas. Em Don Estevan, en grand'entençon, o diálogo literário com ambas as cantigas de Joam Soares Coelho é intenso, o que poderá confirmar a ideia de ter sido Coelho, ao serviço de Afonso III, a juntá-lo ao grupo de atacantes do Arcebispo. Além de alusões diretas à cantiga de Coelho, neste texto, o verbo «ver» tem, como em ambas as cantigas de Coelho, o sentido de «entender».

Em Don Marco, vej'eu muito queixar, embora Roi Queimado nos apresente um retrato satírico do Arcebispo, coincidente com o que resulta das outras cantigas, a abordagem é francamente mais inovadora. No jogo com o verbo «ver», este ganha um novo sentido - «visitar» -, mas esta não é a única novidade criativa, dentro do conjunto satírico, num texto em que é mencionado um notário do poderoso bispo da Guarda e antigo chanceler de Sancho II: mestre Vicente.

Queimado retoma, nesta cantiga, o tema da fúria explorado por Vuitorom e Tenoiro, embora de forma menos central, e a acusação transversal de ser dependente de dependentes; portanto, obrigado a entender-se com inferiores, embora nem mesmo a estes consiga impor-se. A alusão a D. Marco na cantiga de Queimado é igualmente uma alusão a mestre Vicente, uma forma de dizer que os interlocutores do arcebispo de Braga não eram pessoas como mestre Vicente, 
mas os seus notários, e que até estes o desprezavam. Tendo mestre Vicente morrido em setembro de 1248 , é possível que as quatro cantigas desta derradeira fase de composição do conjunto datem dos meses posteriores ao fim de janeiro de 1248 (morte de Sancho II) e anteriores a setembro do mesmo ano.

A pressão satírica dos trovadores contra o Arcebispo teria cumprido o objetivo político, quando Joam Viegas deixasse de insistir em acompanhar constantemente o novo Rei, exigindo-lhe paralelamente o cumprimento das promessas feitas para chegar ao poder. Quando, de alguma forma, o Rei sentisse dominar suficientemente o poder clerical. Ou quando encontrasse forma mais eficaz ou vantajosa de atingir o mesmo objetivo, substituindo o esforço trovadoresco. Fosse como fosse, dos quatro trovadores envolvidos no conjunto satírico contra «Don Estevan», Vuitorom, Tenoiro e Queimado regressarão a Castela. Joam Soares Coelho ficará em Portugal, integrado no grupo dos conselheiros de Afonso III.

No conjunto de oito cantigas satíricas que compuseram, em três tempos diferentes com três objetivos políticos diferentes, os quatro trovadores deixaram um retrato do arcebispo de Braga a que chamaram «Don Estevan» bastante consistente: homem ambicioso que age por interesse e sem qualquer atenção a princípios nem aos interesses coletivos ou mesmo corporativos; procura pretextos para não recompensar os que o servem, economizando; político estúpido, incapaz de compreender além do óbvio, incapaz de antecipação, de se adaptar às circunstâncias, incapaz de se comportar em ambientes socialmente exigentes, inábil diplomata, infantil na argumentação, dependente dos seus dependentes, de caráter irascível, incapaz de se fazer respeitar pelos do mesmo nível hierárquico, preferindo entender-se com os seus inferiores. Joam Viegas de Portocarreiro morre à frente do arcebispado de Braga, em 1255.

O estudo do conjunto satírico contra Joam Viegas, ou «Don Estevan», mostrou que, em circunstâncias caraterizadas por rápidas mudanças, como aquelas em que foram compostas as cantigas estudadas neste livro, o contexto tem uma influência determinante na interpretação de objetos literários muito marcados pela respetiva performance e cuja criação foi muito orientada para a ação sobre a realidade, neste caso política. Refiro-me especificamente ao facto de Tenoiro e Vuitorom terem servido objetivos políticos totalmente diferentes, embora tivessem visado a mesma personagem histórica, nas duas cantigas que ambos fizeram. $\mathrm{E}$ ao facto de esta diferença se ter provavelmente refletido na abordagem diversa que reconhecemos nas cantigas feitas com objetivos diferentes. Refiro-me também ao facto de a própria substituição do nome Joam Viegas pelo nome «Don Estevan», embora seja exatamente a mesma, ter implicações diferentes quando feita inicialmente por um autor (Joam Soares Coelho) e quando feita posteriormente por outros autores (Vuitorom e Tenoiro). Refiro-me ainda ao 
facto de que a adoção de uma ideia literária, como a substituição de um nome por outro nome, pode não significar total aceitação e concordância, mas discussão entre trovadores com pontos de vista diferentes, pelo menos em certo momento, e ansiosos por marcar uma certa individualidade literária ou, como parece acontecer, por marcar a diferença estilística entre grupos.

O estudo do conjunto, que de seguida se apresenta, foi, portanto, determinante, não só para resolver questões específicas, como a identificação de «Don Estevan» e D. Marco, a atribuição e a edição crítica de textos ou o esclarecimento de vocabulário, mas também para compreender aquilo a que, numa alusão à teoria da relatividade de Einstein, metaforicamente poderíamos chamar «a forma do espaço». Ou seja, as ondas gravitacionais (e invisíveis) que condicionam tudo aquilo que se vê. 



\section{Textos: edição crítica e interpretação}

Os autores que têm consensualmente sido envolvidos pela crítica nos ataques a «Don Estevan» são os seguintes: Airas Peres Vuitorom, Mem Rodrigues Tenoiro, Roi Quimado e Joam Soares Coelho. Os dois cancioneiros a que devemos a transmissão das cantigas divergem quanto à atribuição de uma das cantigas aos dois primeiros trovadores. Um dos cancioneiros considera-a de Airas Peres Vuitorom e o outro considera-a de Mem Rodrigues Tenoiro. Comecemos por esta questão, para chegarmos a uma lista inicial de trovadores, e de cantigas dedicadas a «Don Estevan».

Angelo Colocci, secretário do Papa no início do século XVI e humanista, tinha o gosto e o hábito de colecionar cancioneiros de lírica medieval. Quando teve oportunidade, mandou por isso fazer duas cópias de um cancioneiro galego-português. Uma destas cópias está hoje guardada na Biblioteca do Vaticano e chamamos-lhe Cancioneiro da Vaticana (v); a outra cópia está hoje guardada na Biblioteca Nacional de Portugal, em Lisboa, e chamamos-lhe precisamente Cancioneiro da Biblioteca Nacional (B). Na cópia deste último cancioneiro, participaram seis copistas (para apressar a cópia) e Colocci anotou-o abundantemente; pensamos por isso que deveria considerá-lo um volume de trabalho ${ }^{1}$.

Em ambos os cancioneiros, a atribuição da autoria das cantigas fez-se escrevendo o nome de um autor, antes da primeira cantiga de uma série que lhe pertencesse. Colocci terá dado ordens aos copistas para não copiarem as rubricas atributivas, uma vez que queria ser ele a fazê-lo. As razões desta decisão estariam provavelmente relacionadas com o índice de autores, que depois fez e que conhecemos por Tavola Colocciana ${ }^{2}$. Para elaborar este índice, Colocci procurava no cancioneiro as rubricas escritas com a sua própria letra, para escrever numa folha de papel o nome do autor e o número da cantiga que se lhe seguia.

1 Abibliografia sobre os cancioneiros galego-portugueses, sobre a respetiva constituição e as respetivas relações de cópia é vasta e complexa. Indico aqui os títulos essenciais, onde colhi as informações sobre o assunto de que disponho neste livro: Vasconcelos (1990a); Tavani (1967a); D’Heur (1974; 1984); Gonçalves (1976); Ferrarri (1979); Oliveira (1994).

2 Devemos a Elsa Gonçalves (1976) o estudo da Tavola Colocciana e do processo que conduziu Angelo Colocci à sua elaboração. 
Mas voltemos à cópia das rubricas no cancioneiro B: os copistas receberam indicações para copiar as cantigas, saltando as rubricas atributivas. A ordem colocciana nem sempre foi seguida, e alguns nomes de trovadores foram escritos pela mão dos copistas. Uma das razões para esta desobediência poderá ter sido o facto de, naquele lugar do antecedente, a rubrica atributiva não ter as mesmas caraterísticas gráficas das outras rubricas atributivas, e os copistas não as terem identificado como a parte que deveriam deixar por copiar. Em todo o caso, por esta razão é a letra de Colocci que se mostra quase sempre, mas nem sempre, nas rubricas atributivas do cancioneiro $\mathrm{B}$.

A cantiga Don Estevam achei noutro dia está precedida, no cancioneiro в (1472), de uma rubrica que a atribui a Mem Rodrigues Tenoiro, escrita pela mão do copista. Sabendo nós que o copista procedia olhando alternadamente para o seu modelo e para o papel onde lançava a cópia, não temos razão para questionar esta atribuição. Ou seja, não temos razão para duvidar de que o copista encontrou no modelo da cópia a rubrica copiada no local onde a copiou. A partir daqui, o copista volta a abster-se de copiar rubricas e é Colocci que o faz.

Ora, embora Colocci também proceda a uma cópia destes nomes, o modo como procede é totalmente diferente do do copista e muito mais propício ao erro. $\mathrm{Na}$ verdade, para lançar os nomes dos trovadores no cancioneiro, a operação de cópia a que Colocci se dedica não é uma simples operação de cópia contínua como a do copista. Quando Colocci acaba de escrever um nome antes de uma composição já copiada pelo copista, tem de voltar-se para o antecedente e encontrar o nome que acaba de escrever, o que não terá sido problemático, se o deixou marcado de alguma forma. Mas, depois, tem de procurar a rubrica seguinte no antecedente, tem de memorizar o início da primeira cantiga que se seguir à rubrica, tem de voltar-se para a cópia feita pelo copista, percorrer todas as cantigas que se sigam à última rubrica copiada, lendo todos os primeiros versos, até encontrar a cantiga cujo início acaba de memorizar, para escrever, antes dela, o nome do trovador.

Este processo de cópia encontrava, na sequência das cantigas de Tenoiro e Vuitorom, um lugar especialmente propício ao erro, porque se encontram ali, em sequência, três cantigas exatamente com o mesmo início: «Don Estevan». Não é de admirar que Colocci, no processo de cópia que acima descrevi, memorizasse o início do verso «Don Estevan» e escrevesse a rubrica atributiva «Ayras Perez Vuytor», antes da primeira cantiga com este início, a seguir à rubrica atributiva anterior. Foi o que fez no cancioneiro в (в1473: Don Estevan eu eiri comi).

No cancioneiro $v$, é possível que as mesmas caraterísticas gráficas que enganaram o copista de $\mathrm{B}$ e o levaram a copiar a rubrica atributiva a Mem Rodrigues Tenoiro tenham enganado Colocci, num primeiro momento também. Porque, tal como o copista copiou a rubrica que não deveria ter copiado, Colocci ignorou-a. Imaginemos, por exemplo, que, no antecedente, as rubricas atributivas estavam escritas a tinta vermelha, exceto algumas que, por lapso ou por qualquer circuns- 
tância específica, o não estivessem. Se Colocci tivesse dado aos seus copistas a ordem simples de «não copiar as rubricas, escritas a vermelho»; о copista de $\mathbf{B}$ poderia ter julgado que, por não estar a vermelho, não seria rubrica, ou poderia ter decidido que seria melhor copiar as rubricas não escritas a vermelho. Por seu lado, Colocci, no processo de localizar, no antecedente, as rubricas escritas a vermelho para as copiar, saltaria facilmente as que não estivessem escritas a vermelho.

No processo de cópia das rubricas para o cancioneiro v, Colocci terá saltado, portanto, no momento da leitura, a rubrica atributiva a Mem Rodrigues Tenoiro e terá encontrado, logo a seguir, a rubrica atributiva a Airas Peres Vuitorom. Copiou-a imediatamente antes da primeira cantiga que começava por «Don Estevan», ou seja, antes da cantiga atribuída, em B, pela mão do copista, a Mem Rodrigues Tenoiro. Mas Colocci, provavelmente mais tarde, num processo de comparação que desconhecemos, deu-se conta do erro. Possivelmente, deu-se conta de que o trovador Mem Rodrigues Tenoiro estava indevidamente em falta naquele lugar do Cancioneiro v. Neste momento de revisão, Colocci risca o nome de Airas Peres Vuitorom e substitui-o pelo nome de Mem Rodrigues Tenoiro antes da cantiga Don Estevan achei noutro dia (v1083). Tem agora de voltar a escrever o nome de Airas Peres Vuitorom no lugar certo. Nesta fase de revisão, Colocci já não se encontra no processo de cópia que acima descrevi, mas numa altura de redobrada atenção a um local onde detetou um erro cometido anteriormente durante aquele processo de cópia. Será, pois, natural que, neste momento de correção, ao escolher o local onde voltar a escrever a rubrica atributiva a Airas Peres Vuitorom procure prevenir-se contra erros. Já não terá, então, memorizado apenas o início da cantiga antes da qual deve escrever a rubrica. É mais provável que, tendo regressado a este ponto do cancioneiro para corrigir um lapso, se assegure de que está a optar pelo lugar exato para voltar a escrever a rubrica de atribuição a Vuitorom, dando atenção a mais do que o início do primeiro verso da cantiga. O lugar que escolhe, em v, para escrever a rubrica atributiva a Airas Peres Vuitorom não coincide com o lugar escolhido em в. No cancioneiro v, Colocci escreve o nome de Vuitorom antes da cantiga Don Estevan tan de mal talan (V1085), deixando atribuídas a Mem Rodrigues Tenoiro as duas cantigas anteriores (v1083: Don Estevan achei noutro dia e V1084: Don Estevan, eu eiri comi), ao contrário do que fizera em B, onde deixara atribuída a segunda (B1473: Don Estevan, eu eiri comi) também a Airas Peres Vuitorom.

Dados os processos de cópia e revisão descritos, creio que deveremos aceitar a atribuição que Colocci faz, em momento de mais provável concentração e ponderação, ao corrigir e copiar as rubricas atributivas do antecedente no cancioneiro $\mathrm{v}^{3}$.

3 R. Oliveira considera a mesma atribuição da cantiga Don Estevan, eu eiri comi a Mem Rodrigues Tenoiro, embora com base numa argumentação um pouco diferente (1994: 320). Em Oliveira (1994: 54), nota 23, o historiador resume as posições anteriores dos estudiosos sobre o assunto, nomeadamente as de R. Lapa, 
Resolvida esta questão, poderemos partir de uma lista de autores e cantigas que consensualmente se consideram dedicadas à mesma figura nomeada «Don Estevan ${ }^{4}$; uma lista em que, a cada autor, correspondem duas cantigas:

\begin{tabular}{lll} 
Roi Queimado & Don Estevan, en grand'entençon & $(\mathrm{B} 1386 / \mathrm{v} 995)$ \\
& Don Marco, vej'eu muito queixar & $(\mathrm{B} 1388 / \mathrm{v} 997)$ \\
Joam Soares Coelho & Don Estevan fez sa partiçon & $(\mathrm{v} 1014)$ \\
& Don Estevan, que lhi non gradecedes & $(\mathrm{v} 1015)$ \\
\multirow{4}{*}{ Mem Rodrigues Tenoiro $)$} & Don Estevan achei noutro dia & $(\mathrm{B} 1472 / \mathrm{V} 1083)$ \\
& Don Estevan, eu eiri comi & $(\mathrm{B} 1473 / \mathrm{V} 1084)$ \\
\multirow{2}{*}{ Airas Peres Vuitorom } & Don Estevan, tan de mal talan & $(\mathrm{B} 1474 / \mathrm{v} 1085)$ \\
& Don Estevan diz que desamor & $(\mathrm{B} 1478 / \mathrm{V} 1089)$
\end{tabular}

Começarei a edição ${ }^{5}$ e interpretação deste conjunto satírico pela cantiga cujas referências nos permitem ancorar no tempo e nos acontecimentos do tempo a figura de «Don Estevan». Esta cantiga é, sem dúvida, Don Estevan diz que desamor, de Airas Peres Vuitorom. Prosseguirei a edição e o estudo pelos textos cujas afinidades de referências e vocabulário poderão beneficiar da pesquisa previamente feita.

G. Tavani e J. M. D’Heur. Omite, no entanto, o artigo dedicado por G. Marroni (1971) ao assunto das divergências de atribuição que envolvem o cancioneiro de Mem Rodrigues Tenoiro. Neste artigo, a estudiosa italiana já chama a atenção (ibidem, p. 274) para a circunstância de as três cantigas com o mesmo início poder ter perturbado a atribuição das cantigas. Não usa porém o argumento para defender nenhuma tomada de posição. Apenas se inclina para a atribuição da cantiga a Airas Peres Vuitorom por coincidência de conteúdo, estilo e léxico com as cantigas deste trovador sobre o mesmo assunto (ibidem, p. 276), em especial, o uso ambivalente do verbo «ver». Sabemos que o uso a que a autora se refere se repete nas cantigas de outros autores, pelo que o argumento não é conclusivo, como a autora admite ao rematar que a Mem Rodrigues Tenoiro se deve atribuir «una tenzone e una o due cantigas de maldizer» (ibidem, p. 277).

4 São levantadas algumas dúvidas sobre se a cantiga Don Marco, vej'eu muito queixar, de Roi Queimado, teria o mesmo visado das outras (CMgP-Cantigas Medievais Galego-Portuguesas). A cantiga Don Estevan, oí por vós dizer, de Pedr'Amigo de Sevilha, tem sido consensualmente afastada deste conjunto de cantigas. V. Beltrán (200o) propôs uma interpretação que a relaciona com o nobre castelhano D. Esteban Fernández de Castro e a revolta contra Alfonso X ocorrida entre 1272 e 1274, interpretação que tem sido aceite pela crítica. R. Oliveira (2006: 236), nomeadamente, invoca razões cronológicas para afastar a cantiga de Pedr'Amigo do conjunto dedicado a «Don Estevan», na época da Guerra Civil Portuguesa. Deixarei a análise desta questão para outra sede.

5 A edição crítica dos textos foi feita a partir da leitura das edições fac-similadas dos cancioneiros в (1982) e v (1973), cuja lição foi emendada, apenas quando tal se verificou indispensável e apenas quando se reuniu argumentação suficientemente forte. $\mathrm{O}$ aparato crítico negativo apresenta-se em nota de rodapé, assim como a justificação de eventuais divergências e convergências com o trabalho de editores anteriores. As normas de transcrição seguidas são as mais habituais, considerando o objetivo de regularizar a grafia sem deturpar a interpretação dos sons e sentido representados. Cabe apenas destacar que foi usado o acento agudo para distinguir palavras homógrafas, que o apóstrofo indica elisão e que a pontuação é interpretativa, de acordo com o uso moderno. Para uma consulta em pormenor dos critérios de edição e das normas de transcrição veja-se Correia (2001: 207-210). 


\section{Airas Peres Vuitorom}

1 Don Estevan diz que desamor 6

a con el-rei e sei eu ca ment' $i$

ca nunca viu prazer pois foi aqui

o conde, nen veerá mentr'el i for

5 e per quant'eu de sa fazenda sei porque non ven ao reino el-rei non vee cousa ond'aja sabor.

Con arte diz que non quer a 'l-rei ben ca sei eu d'el ca ja non veera

10 nunca prazer se o cond'o rein'a ca ben quit'é de veer nulha ren Don Estevan ond'aja gran prazer dest'é ja el ben quite de veer mentr'o cond'assi ouver Santaren.

III 15 Porque vos diz el que quer a 'l-rei mal?

Ca ren non vee, assi Deus mi perdon, que el mais am' eno seu coraçon nen veera nunca, e direi-vos al pois que s'agora o reino partiu: 20 prazer pois nunca Don Estevan viu nen veera jamais en Portugal.

$6 \quad \mathbf{B 1 4 7 8} / \mathbf{v 1 0 8 9}$ Aparato crítico - 1. estenan в esteuam v O copista de $v$ escreveu inicialmente um $\mathrm{N}$ maiúsculo, que riscou, corrigindo, no espaço entre as colunas, onde lançou um «D» maiúsculo; 2. rõ el Rey B; 5. say B; 10. seo cõde BV 11. qnite de vee B; 16 . assy de mi pardon в sublinhado, provavelmente por Colocci, que terá dado conta do erro; 17. ame eno sen v; Entre o verso 18 e o verso 19 foram escritos e riscados, em $\mathrm{B}$, dois versos e meio alheios a esta cantiga (Saluo e quẽ Trae Castelo / A p $\mathrm{p}^{\mathrm{c}}$ yto q̃), versos que terminam a cantiga anterior (1477), transcrita na coluna A do mesmo fólio. - A presente edição afasta-se da de R. Lapa (1970a: 133) no verso 10, onde o filólogo preferiu editar «se o Conde reinar á» com a justificação de que se impõe «a separação dos elementos perifrásticos, que dão o sentido: "houver de reinar" ». No entanto, esta emenda, além de tornar o verso hipermétrico, não encontra fácil justificação do ponto de vista paleográfico, diante da sólida concordância dos manuscritos. Mais fácil será conjeturar uma corriqueira confusão entre um «o» e um «e», vendo na vogal com que termina a palavra «conde» a deturpação do artigo «o».Já Braga (1878: 208) e Elza Machado e José Machado (1949-1964, vol. 7, p. 188) tinham proposto a separação «reyn'a» (LAPA 1970a: 133), que Lapa, sem o artigo definido antes de «reino», não pôde evidentemente aceitar. Torna-se de resto esta expressão (haver o reino) paralela da usada nesta mesma estrofe para Santarém («mentr'o Cond'assi ouver Santaren»). Embora na edição de R. Lapa (ibidem, p. 133) o início do verso 15 pareça introduzir uma interrogação («Por que vos diz el...»), o filólogo não a marcou com ponto de interrogação. Considero que, à pergunta aqui lançada, segue-se a resposta no verso seguinte ( $\ll$ Ca ren non ve»), pelo que o ponto de interrogação faz falta no fim do verso 15, onde CMGP o colocou. R. Oliveira, pelo contrário, considerou que o final da interrogação estaria a meio do verso 18, 
As referências históricas nesta cantiga permitem-nos uma datação bastante precisa. São referidos «o conde» e «el-rei», ou seja, o conde de Bolonha, futuro Afonso III, e Sancho II. O sujeito da cantiga refere um período de tempo em que o Conde «pois foi aqui», ou seja, o tempo desde que o Conde chegou ao reino (dezembro de 1245) e nele permanece («mentr'el i for»), está na posse de Santarém («mentr'o cond'assi ouver Santaren»), mas em que o reinado é ainda uma possibilidade ( «se o cond'o rein'a»). Como se sabe, o Papa entregou ao Conde o governo de Portugal, mas não a coroa, que apenas deveria ser-lhe entregue após a morte de Sancho II, e apenas na condição de Sancho II morrer sem herdeiros. É precisamente esta a razão por que Afonso III, em 1246, manda raptar a rainha Mecía que, até então, não tivera filhos de Sancho II. O rapto é liderado por um dos irmãos do arcebispo de Braga, Raimundo Viegas de Portocarreiro ${ }^{7}$.

O tempo referido na cantiga é, portanto, um tempo em que o Rei se encontra já ausente do reino, mas ainda vivo: «porque non ven ao reino el-rei»; «pois que s'agora o reino partiu». Carolina Michaëlis atribuiu ao verbo «partir» neste segundo verso o sentido de «quebrar», que ele também tem ${ }^{8}$. Mas não neste verso, onde o sentido é o de afastar-se. A confusão resultou provavelmente da ausência da preposição «de», que habitualmente acompanha o verbo «partir», quando tem o sentido de afastar-se. Mas nem sempre assim acontecia. Por exemplo, na cantiga de Santa Maria $55(\ll \mathrm{E}$ foi ao mõesteiro ali onde sse partira $\left.{ }^{9}\right)$, como aqui, a preposição é dispensada. Considerando o verso anterior, onde também se dá conta da ausência do Rei, não restam dúvidas de que a data de composição desta cantiga será posterior à partida de Sancho II para Toledo, em março de 1247, e anterior à morte do ainda Rei, no final de janeiro de 1248.

Passou, portanto, já o tempo em que Sancho II e os seus fiéis resistiram em Coimbra, passou o tempo em que o infante Alfonso de Castela reuniu tropas junto à fronteira, se esforçou por influenciar no sentido da defesa de Sancho II; passou o tempo da incursão em Leiria, sem continuidade. Sancho II e Alfonso saíram já do reino, mas Vuitorom permanece ainda. Pelo menos Vuitorom, se não mais dos que usaram o canto em prol de Sancho II, aliciados por Alfonso ${ }^{10}$.

ou seja, no quarto verso da estrofe («nen veera nunca?»), o que impõe uma interpretação difícil de conciliar com a interpretação geral do texto (OLIVEIRA 2006: 238). CMGP faz, no verso 19, uma integração desnecessária («pois que s'agora [d]o reino partiu»), uma vez que a preposição podia ser dispensada, mesmo quando o sentido do verbo «partir» era o de afastar-se. Demonstra-o, por exemplo, a cantiga de Santa Maria 55: «E foi ao mõesteiro ali onde sse partira» (METTMANN 1986-1979, vol. 1, p. 191).

7 Mais informação nos capítulos «A deposição»e « «oam Viegas de Portocarreiro».

$8<\mathrm{O}$ verso: pois que s'agora o reino partiu significará que uma parte dos senhores do castelo ainda conservara a lealdade» (VASCONCELOS 2004: 85-86).

9 Mettmann (1986-1989, vol. 1, p. 191).

10 R. Oliveira não admite a possibilidade de que Vuitorom tenha permanecido em Portugal após a retirada de Alfonso de Castela («Do verso 3 retira-se igualmente a indicação de que Vuitorom se encontraria ainda 
Airas Peres Vuitorom, que terá chegado ao reino com Alfonso, ou tê-lo-á precedido, para prestar auxílio a Sancho II, fala ainda na primeira pessoa, adotando o ponto de vista de quem está no reino de Portugal, longe de Sancho e perto do Conde e de «Don Estevan». Parece oscilar entre a possibilidade de uma reversão da situação política («nunca viu prazer pois foi aqui / o conde, nen veerá mentr'el i for») e a impossibilidade de uma tal reversão («pois que s'agora o reino partiu: / prazer pois nunca Don Estevan viu / nen veera jamais en Portugal» $)^{11}$. Talvez a sátira se prenda ainda com alguma espécie de expetativa, o que significaria não ter a partida de Sancho II sido inicialmente definitiva. Apenas uma retirada estratégica para voltar à carga mais tarde, tendo ficado os trovadores para agir sobre as mentalidades e moldar as perspetivas. Neste caso, teria sido a morte de Sancho II, precedida talvez de doença, a impedir o regresso e a recarga.

Quanto a «Don Estevan», é acusado pelo sujeito da cantiga de fazer afirmações falsas: «diz que desamor / a con el-rei e sei eu ca ment' $i$ »; «Con arte diz que non quer a 'l-rei ben»; «Porque vos diz el que quer a 'l-rei mal?». Segue-se invariavelmente a esta declaração uma justificação, introduzida por «ca». É nesta justificação que tem papel principal o verbo «ver», sempre no âmbito da sequência «ver prazer» ou «ver sabor», pontualmente substituída pelas mais esclarecedoras «vee cousa ond'aja sabor» e «ren... ond'aja gran prazer». O verbo «ver» tem, portanto, nesta cantiga, o sentido de «receber»e, segundo o sujeito, «Don Estevan» nunca recebeu nada, desde que o Conde chegou a Portugal, nem nunca receberá enquanto o Conde permanecer em Portugal e o Rei estiver ausente do reino.

É importante ter em atenção que o substantivo «desamor», usado neste texto logo no incipit, e o verbo «amar», usado na última estrofe, não têm, neste contexto, o sentido exclusivamente afetivo. Esta densidade semântica fica claramente estabelecida com as múltiplas e claras referências aos benefícios que «Don Estevan» recebe, não recebe ou espera receber do Conde ou do Rei, senhores feudais. Falamos, pois, de recompensa no âmbito de serviço de tipo feudo-vassálico, e tanto o amor quanto o desamor a que o sujeito se refere têm caráter mais jurídico que afetivo.

em Portugal. Ora como essa presença terá estado dependente, como vimos, da colaboração prestada pelo infante D. Afonso de Castela ao Rei português, poder-se-ia ainda restringir um tanto aquela cronologia e situar a composição talvez por fevereiro/março de 1247» (OLIVEIRA 2006: 237). Não é, no entanto, o que pode ler-se no texto.

11 Carolina Michëlis também leu nestes versos sinais de esperança: «As fórmulas mentr'el i for... se o Conde reinará e mentr'o Conde assi ouver Santarem indicam provavelmente que ainda existia um resto de esperança ou probabilidade de derrota do Conde e vitória do Rei ausente, que certamente era esperado de Castela, com tropas de auxílio» (VASCONCELOS 2004: 86). 
Neste âmbito semântico, o amor está associado à recompensa, como podemos comprovar, na documentação onde o amor é frequentemente a justificação de doações. A ligação é tão forte que a expressão «fazer amor de» é usada para significar «doar» ${ }^{12}$. Em documento particular de 1234, por exemplo, os filhos de Martim Moniz e Ximena Pais pedem à abadessa de Vairão, Mor Lourenço de Arões, que lhes «fizesse amor» da herdade do Tamial ${ }^{13}$. Mas vejam-se outros exemplos de documentação onde a recompensa é justificada pelo amor:

E este amor ${ }^{14} \mathrm{e}$ este quitamento que vos fazemos de todas las cosas sobredichas fiziemos lo por muchos dobdos de bien que son entre nos e vos e vostra mugier e vostros fijos e por la ayuda que nos feziestes en nostra guerra por mar e por terra (VENTURA e OLIVEIRA 2006: 435).

Et mando quod donna Constancia teneat in vita sua illam hereditatem quam modo ibi habet sicut eam tenebat in diebus mariti sui et post mortem suam ipsa hereditas dividatur inter pauperes Ulixbone qui non habuerint aliam hereditatem in qua laborent sicut avus meus et pater meus illam dividere mandaverunt. Et istum amorem facio donne Constancie pro servitio quod maritus suus mihi fecit et quia ipsa est domina cum qua habeo debitum (ibidem, p. 413).

Do vobis et concedo ipsum casale cum omni iure suo et pro amore quod michi fecistis et pro una buzeta de tiriaga quam michi dedistis apreciata in X. ${ }^{a}$ morabitinos, tantum michi et vob is bene complacuit (FERNANDES 1991: 142).

grato habeo vobis uxori mee domne Sancia Petri de isto amore quam mihi facitis et laudo et confirmo istam cartam medietatis et plazum quod mecum facitis (VENTURA 1992: 235).

pro amore domni Simeonis (concessão a D. Simão Soares, mestre de Avis, da igreja de santa Maria de Beja e seu padroado) (ibidem, p. 236).

pro multo auxilio et amore quem nobis facistis et fecistis (ibidem).

12 M. de Riquer considera que os trovadores usaram a palavra «amor» também no sentido feudo-vassálico, exemplificando com versos de Guillem de Berguedà ( $\ll$ Tot atrestal en tal amor / com de vassal e de segnor, / tolc mi castel de Monmajor»). Refere diversos documentos, datados dos séculos XII e XIII, onde ocorre a palavra «amor», a que atribui o sentido jurídico de «gracia, favor, pacto, alianza» (RIQUER 1983, vol. 1, p. 84-85).

13 TT-Vairão, m. IV, doc. 9 (apud ventURA 1992, vol. 1, p. 237, n. 2).

14 O negrito é da minha responsabilidade e tem o objetivo de destacar, aqui e daqui em diante. 
vocate maiordomum de regalengo et date ei pro foro $[\ldots]$ et pona te pede de lagar III vices non plus et faciat vobis bonum amorem (ibidem).

quod ipse propter istum amorem quod sibi facimus teneatur juvare monasterium nostrum (ibidem, p. 237).

et pona te pede de lagar III vices non plus et faciat vobis bonum amorem (ibidem, p. 236).

Esto foi en Lonbardia dun jograr remedador / que atan ben remedava, que avian en sabor / todos quantos lo viian, e davan-lle con amor / panos e selas e frẽos e outro muito bon don (METTMANN 1986-1989, vol. 3, p. 81).

E el-rei disse aos que cabo delle siam: «Certas, amigos, muito deviamos a seer ledos, que Deos nos mostrou tam gram signal damor, que em tam bõa festa como oje de Pinticoste nos deu a comer do seu santo celleiro» (PÍEL 1988: 16).

Quando «Don Estevan» é denunciado a queixar-se do «desamor» do Rei, não creio que a denúncia deva interpretar-se no sentido dos afetos ou do simples entendimento, mas no sentido das recompensas, como aliás a sequência do texto esclarece. Segundo Vuitorom, «Don Estevan», em provável justificação para a posição assumida na guerra civil em curso, teria, portanto, declarado não ter recebido suficientes benefícios, suficiente expressão do amor do Rei que, note-se, é um gesto juridicamente estabelecido. Nas Ordenações de Afonso III, por exemplo, «perder o amor de el-rei» corresponde a um castigo. Veja-se a Constituição XXX, onde o Rei legisla sobre matéria tão prosaica quanto a quantidade de alcaides a haver nas vilas grandes. Depois de, na lei, estabelecer a regra a observar, estipula-se o castigo para quem lhe desobedeça, nos seguintes termos: «E se alguum alcaide for tam ousado que ponha de so sa maão mais que huum alcaide em esa uilla E seus termos. perca por eso a alcaidaria E o meu amor» (ALBUQUERQUE e NUNES 1988: 74). Há ainda o seguinte outro exemplo: «E se alguum uogado der ou prometer ou fezer dar ao alcaide sobr'esta defesa $E$ lhe for prouado perca o meu amor. E o ofiçio da uogaria por tres anos E torne ao meu moordomo desa uilla en dobro quanto ouuer» (ibidem, p. 76).

Por seu lado, Vuitorom discorda desta visão de «Don Estevan», apontando-lhe o que não recebeu desde que o Conde entrou no reino e desenganando-o quanto ao que receberá. Deixa assim entendido que «Don Estevan» terá recebido do Rei o que «Don Estevan» considerava insuficiente. É desta comparação entre os bens recebidos do Rei, por um considerados insuficientes (ato de desamor) e por outro considerados ato de amor maior, e o que aquele receberá do Conde que resulta a acusação de mentira. Se «Don Estevan» pensa 
que não «ama» o Rei, isto é, está fora do círculo de amor político-jurídico do Rei por não ter sido suficientemente beneficiado por ele, quando comparar com o que receber do Conde se verá que, pelo contrário, o ama muito, já que foi por ele muito amado, ou seja, muito beneficiado.

$\mathrm{Na}$ última estrofe, embora a repetição semântica se mantenha, há uma mudança que reforça o retrato de cupidez associada a «Don Estevan». Em resposta a uma pergunta inicial (por que diz «Don Estevan» que quer mal ao Rei?) o sujeito responde, tal como na segunda estrofe, que «Don Estevan» quer mal a el-rei porque não obtém nada («ren non vee») a que ele possa ter maior amor no seu coração. Esta reforçada expressão de amor aos bens recebidos em recompensa - «ren non vee $[\ldots]$ que el mais am'eno seu coraçon» - desloca tão claramente o sentido da leadade ao senhor para a lealdade à recompensa que deixa totalmente esclarecidos os motivos do partido tomado por «Don Estevan» na guerra civil. Vuitorom acredita que ele, mesmo à luz dos interesses que o moveram, fez a escolha errada; que leu mal a situação. Ou... como também poderíamos dizer, que a viu mal.

Desta cantiga, indiscutivelmente relacionada com os acontecimentos políticos da guerra civil de 1245-1248, fica associada a «Don Estevan» a acusação de ter escolhido um partido na perspetiva de receber mais benefícios, mas também a expressão da convicção de que este será um tiro a sair pela culatra ao visado, já que, se pensa ter recebido poucos benefícios do Rei, do Conde pode esperar não receber nenhuns. Se pelos benefícios recebidos queria sair da esfera de amor político-jurídico do Rei, em comparação com o que haverá de receber do Conde, «Don Estevan» mente com certeza, já que tinha bons motivos para se manter naquela esfera de amor político-jurídico ${ }^{15}$.

Não se trata, nesta cantiga, de uma acusação de deslealdade pela entrega de castelos, como noutras cantigas. Aqui, a acusação é simplesmente a de «Don Estevan» ter agido por cupidez, pensando em receber mais benefícios do Conde

15 R. Lapa confessa dificuldades na interpretação desta cantiga, mas a interpretação que faz tende a ver nela uma manifestação de indecisão de «Don Estevan» sobre que partido escolher: «Vuitoron parece nela pôr em dúvida a fidelidade de Estêvão Anes ao Conde de Bolonha, de quem não poderia ver grande coisa, e representa-o a suspirar ocultamente pelo Rei, de quem dizia mal para disfarçar. É natural que naquele momento de luta, por volta de 1246 , em que as forças dos dois partidos se equilibravam, muitos vacilassem e adoptassem uma atitude bifronte perante os contendores.» (LAPA 1970a: 133). Aceitando esta interpretação, R. Oliveira (2006: 238) cita os versos 15 a 18 introduzindo, no entanto, importantes alterações na edição de R. Lapa a estes versos fundamentais: «Porque vos diz ele que quer ao Rei mal / se não vê nada [...] / que ele mais ame no seu coração / nem verá nunca?». De acordo com a leitura assim refletida, nomeadamente, tendo em conta o lugar da interrogação (que em R. Lapa não encontramos), a interpretação do historiador seria que, na opinião do sujeito, «Don Estevan» não veria nada que ele amasse mais do que o Rei, apesar de dizer que lhe queria mal. Não é este o sentido destes versos, embora não fique invalidada a conclusão geral de Resende Oliveira, segundo a qual haveria proximidade entre «Don Estevan» e Sancho II. A proximidade que justificaria os benefícios de que Vuitorom também fala. 
do que recebia do Rei. Fica, no entanto, subentendida uma sátira à falta de conviç̧ão, à ação por interesse exclusivamente individual e egoísta, quando deveria esta ter sido norteada por princípios, se não morais, que tivessem pelo menos subjacente um interesse coletivo ou corporativo.

Cabe ainda sublinhar a insistência no verbo «ver», com o sentido que já sublinhei, num jogo que se repetirá noutras cantigas. É importante notar, porém, que, aqui, Vuitorom dá conta de ser o próprio «Don Estevan» a queixar-se de «não ver»: «diz el que quer a 'l-rei mal / ca ren non vee».

As declarações que Vuitorom faz de seguida, segundo as quais «Don Estevan» não obterá os benefícios do Conde que quereria obter, reinterpreta a ideia de cegueira, não só para uma ideia de ambição, mas, sobretudo, para uma ideia de estupidez, de incapacidade para ler a situação política, de modo a compreender o que o esperaria no futuro e, até, de modo a precaver-se com garantias. A sátira de Vuitorom poria, portanto, precocemente, o dedo numa ferida que se vê sangrar nos documentos onde, poucos anos mais tarde, o clero virá a queixar-se de que Afonso III não cumpre as promessas àqueles que lhe abriram $o$ caminho do poder, ou seja, as promessas do Juramento de Paris, feitas precisamente diante do arcebispo Joam Viegas de Portocarreiro ${ }^{16}$. Vuitorom faz aqui uma profecia que não tardará muito a cumprir-se. Ou talvez não fosse uma profecia, apenas uma evidência para quem tivesse a sagacidade política que precisamente parecia faltar a «Don Estevan».

A associação entre os jogos com o verbo «ver» e a figura designada por «Dom Estevan» marcam grande parte das cantigas do conjunto em análise. Prossegui-la-ei com aquelas em que este jogo se encontra explorado.

\footnotetext{
16 Sirva de exemplo o documento onde foram registadas as queixas apresentadas logo em 1250, pelo arcebispo de Braga e outros bispos, em cortes reunidas em Guimarães, sobre os agravos feitos ao clero, e as respostas dadas pelo Rei (HERCULANO 1856: 185-189).
} 


\section{Mem Rodrigues Tenoiro}

I 1 Don Estevan, eu eiri comi ${ }^{17}$ en cas d' el-rei nunca vistes melhor. E contarei-vo-l' o jantar aqui ca x' á ome de falar i sabor.

5 Non viron nunca ja outro tal pan os vossos olhos nen ar veeran outro tal vinho qual eu i bevi

II nen vistes nunca se Deus mi perdon melhor jantar e contar-vo-lo-ei.

10 Á dez anos que non vistes capon qual eu i ouve nen vistes ben sei melhor cabrito nen vistes atal lombo de vinh' e d' alhos e de sal qual mi a mi deu i un, de criaçon ${ }^{18}$.

III 15 Nen vistes nunca nulh' ome comer com' eu comi nen vistes tal jantar nen vistes mais viços' ome seer do que eu sevi, en nen un logar ca a min minguava nulha ren

20 e mais viços' ome de comer ben non vistes nen avedes de veer.

Nesta cantiga de Mem Rodrigues Tenoiro, a insistência no verbo «ver» associada à figura de «Don Estevan» repete o que já se observou na cantiga de Airas Peres Vuitorom. Repete-se igualmente, embora de forma mais subtil, a atribuição do sentido de receber benefício à expressão «ver algo», sendo «algo», neste caso, concretizado num jantar mirífico, considerando as práticas da época. À quantidade de iguarias - pão; vinho; capão; cabrito; lombo de cria-

B1473/V1084 Aparato crítico - 1. estauam v; 2. nistes B; 3. aqni B; 7. a qual v; 10. cõtaruõoley v; 12. Um sault du même au même ( «vistes») leva o copista de в a omitir o final do verso 11 ( «ben sei $\gg)$ e o verso 12 , à exceção das últimas palavras («atal»); 14. q lhi nami v; 20. uyrosome в.

18 Creio que a locução qualifica a carne do lombo, não a pessoa que a serviu. Seria uma forma de referir uma carne mais tenra, por oposição a uma carne mais dura proveniente da caça. Não faz sentido que se trate de referência ao serviço feito por alguém da criação da casa do Rei, como defende R. Lapa (1970a: 125). 
ção, de vinha d'alhos e de sal; sem esquecer o etc. - junta-se a excelente qualidade de cada uma delas ( $\ll$ Non viron nunca ja outro tal pan / os vossos olhos nen ar veeran / outro tal vinho»; «nen vistes nunca se Deus mi perdon / melhor jantar»; «Á dez anos que non vistes capon / qual eu i ouve»), a quantidade ( «Nen vistes nunca nulh' ome comer / com'eu comi») e o conforto e abundância em que o jantar foi servido ( «nen vistes mais viços'ome seer / do que eu sevi, nen un logar ca a min minguava nulha ren»).

Devo deter-me um pouco no âmbito semântico da palavra «viço»e «viçoso», usadas no final da cantiga em síntese descritiva, para uma mais clara perceção do que se pretende transmitir nesta cantiga. «Viço»e «vício» têm a mesma raiz etimológica e é $\mathrm{D}$. Duarte que, pouco mais tarde, dirá «per o que se afirma o vyço seer sempre acompanhado com vycio e que homem folgadio acabará em proveza de virtudes e bẽes temporaaes » (2012: cap. 26). Das ocorrências do termo na prosa medieval deduz-se o sentido de deleite, descanso, conforto, abundância e despreocupação associados ao luxo, conforme se pode perceber nos exemplos que se seguem, alguns em ligação a comida, mas nem todos. A expressão «viçosos de comer» ocorre em A demanda do Santo Graal, associada a um momento em que basta às personagens rezarem por qualquer comida que desejem, para que esta lhes seja apresentada.

E el-rei sia aa mesa e seus ricos homẽes com elle, e eram mui viçosos de comer, mais nom pero pella graça do Santo Vaso, ca o Santo Vaso nunca saia de Corberic por mão de homem, mais todos aquelles sem falha que no paaço aventuroso comiam eram avondados de quanto aviam mister atanto que orassem em sa vinda (PíEL 1988: 268)

Espanha he muyto avondada de pescados de mar e de pescados de ryos e de lagoas. Espanha he de bõos pãaes, deleytosa de fruytas, muy viçosa de pescados, saborosa de leyte e de todolos mãjares que se delle fazem (CINTRA 1984, vol. 2, p. 40).

$\mathrm{E}$ tomou os meninos e adusseos consigo e fezeos criar assy viçosos e tan honrradamente como cõviinha a filhos de rey (ibidem, p. 300).

E, quando elle vyo tal destroimẽnto na terra e vyo outrossi como os fidalgos nõ podyã sofrer as armas e por esto viinha grãde dampno ao seu senhorio, por sua fraqueza e mĩgua, perguntou os fisicos se sabyam por que os filhos d'algo nõ podyã soportar as armas. E elles the disserõ que por que entravã ameude ẽ os banhos e se davã muito aos viços. E el rei mãdou logo derribar os banhos da terra e fez trabalhar os cavalleiros em armas ennas guerras (CINTRA 1990: 37). 
Os iffantes de Carriõ, despois que forom casados, morarom cõ o Cide dous ãnos mui viçosos e a grande prazer (ibidem, p. 118).

Este dom Pero Fernandez, porque era mui viçoso, disse el rei dom Afonso de Castela que se comporia bem com os Mouros em seus banhos e em seus viços (MATTOSO 1980, vol. II/1, p. 167).

E chegou essa noite a casa de ũu ermitam u ouve mui pouco viço (PÍEL 1988: 62).

Dessi entrarom na egreja e desarmarom-se e teverom-se viçosos do que acharom e poderom sem rem que ouvessem de comer (ibidem, p. 95).

Assi foram albergados e viçosos como se fosse en casa del-rei Artur (ibidem, p. 177).

Ao terceiro dia aveo que rei Nascor foi a caçar em aquela foresta meesma e levou consigo a rainha e muitas donzelas por folgarem e seerem viçosas com elle (ibidem, p. 227).

Como se pode perceber, a ideia de «viço» não anda longe da ideia de riqueza, refastelamento e luxo.

A hiperbólica descrição de tal «jantar» tem um indiscutível toque de maravilhoso, em claro contraste com o contexto político-militar e social em que a cantiga foi composta e apresentada, caraterizado por extrema penúria, violência e insegurança generalizada ${ }^{19}$.

«Ver», considerando o sentido que assume na cantiga anterior, continua a significar aqui receber benefício. Ou seja, de acordo com esta cantiga, «Don Estevan» nunca foi beneficiado com um jantar como este no seu conjunto: «eu eiri comi / en cas d'el-rei nunca vistes melhor»; «nen vistes tal jantar»; «nen vistes mais viços'ome seer / do que eu sevi en nen un logar». Nem nunca foi agraciado com pão semelhante ao servido: «Non viron nunca ja outro tal pan / os vossos olhos $»$. Mas quanto às carnes, o sujeito admite que «Don Estevan» tenha sido agraciado com carne de qualidade semelhante, embora só dez anos antes: «Á dez anos que non vistes capon / qual eu i ouve nen vistes ben sei / melhor cabrito nen vistes atal / lombo de vinh'e d'alhos e de sal». Como na cantiga anterior, também nesta, o sujeito se mostra convicto de que «Don Estevan» nunca verá, ou seja, nunca receberá semelhante benesse no futuro. Estando o jantar descrito associado ao Rei, deduz-se que o afastamento de «Don Estevan» da possibilidade de aceder a semelhante benefício se deve à escolha por este feita por

Sobre o estado social, político e económico do reino, na altura em que estas cantigas foram compostas, veja-se o capítulo «Enquadramento histórico». 
partido contrário ao do Rei, o que, sendo explicitado na cantiga anterior é, nesta, deixado implícito.

Dadas as coincidências já expostas entre esta cantiga e a anterior, podemos ancorar a composição desta cantiga no mesmo período de tempo. Sendo «Don Estevan» uma figura associada ao reino, devemos supor que o Rei ainda se encontra nele. Ou seja, que o jantar referido terá ocorrido em Portugal em casa do Rei, supondo-se a presença do Rei. Neste contexto, os dez anos mencionados no verso 10 assumem uma importância determinante. Na verdade, é precisamente cerca de dez anos antes do exílio de Sancho II em Toledo que começa o período de «tumulto e guerra», descrito no capítulo de enquadramento histórico deste livro. Ou seja, o estado de instabilidade e ausência de exercício da justiça, que se vai instalando na sequência do afastamento de mestre Vicente, em 1236, da chancelaria do reino. Nos dez anos anteriores a esta cantiga, acumulam-se os casos de assaltos e ataques, especialmente às pessoas do clero, mas não só. É natural que, em tempo de insegurança generalizada na circulação de bens e pessoas, num tempo em que a justiça não se aplicava, a indisponibilidade de produtos impedisse a realização de festins, como o que é descrito nesta cantiga ou mesmo outros mais modestos. A alusão ao período de dez anos, mais exatamente a alusão ao fim de um período de dez anos com a realização de um tal jantar, de que «Don Estevan» foi excluído e de que sempre ficará excluído, é uma forma de afirmar a reposição da segurança e da normalização do quotidiano. Mais: uma forma de prometer a prosperidade e de prometer a exclusão dela aos traidores. Esta garantia de mudança firme e duradoura, cantada por Tenoiro, dez anos depois do início do período de «tumulto e guerra», estaria provavelmente ligada à chegada do príncipe castelhano Alfonso a Portugal, reforçando as forças do Rei português ${ }^{20}$.

De resto, a visão mirífica do jantar cantado por Tenoiro e as promessas que tem implícitas recordam a lenda da truta, contada na Crónica de 1419. Segundo esta lenda, durante o cerco feito pelo Conde ao castelo de Celorico da Beira, o alcaide Fernão Rodrigues Pacheco procurava resistir à fome que alastrava, para não quebrar o pacto de vassalagem feito ao Rei. Uma águia, sobrevoando a fortaleza, deixou então ali cair uma truta fresca, que o alcaide mandou cozinhar e mandou oferecer com bom pão e excelente vinho ao Conde, que sitiava o castelo. Mandou entregar também o recado de que poderia manter o cerco quanto tempo quisesse, porque ali não havia falta de mantimentos nem de vontade para defen-

Resende de Oliveira interpreta de modo diferente a referência temporal do verso 10: «Do verso 10 do cantar $[\ldots]$ parece depreender-se que a cegueira de D. Estêvão não era congénita, mas se manifestara somente cerca de 10 anos antes $\gg$ (OLIVEIRA 2006: 238). 
der o castelo. Conta a lenda que o Conde mandou levantar o cerco perante a evidência de abundância (VEnTURA 2006: 80).

Poder-se-ia aproximar esta cantiga, certamente composta em tempo de vida de Sancho II, do tipo de discurso que, tal como o do alcaide de Celorico, visa substituir a realidade por uma fantasia, na esperança de que a fé ajude a realidade a recompor-se o sufciente para imitar a fantasia.

Em ambas as cantigas de Joam Soares Coelho, o jogo com o verbo «ver» mantém-se, mas os sentidos produzidos dentro deste jogo multiplicam-se. Na cantiga que se segue, no entanto, «Don Estevan», ao contrário de ser mostrado excluído dos jantares do Rei, é mostrado a jantar com o Rei. 


\section{Joam Soares Coelho}

I 1 Don Estevan, que lhi non gradecedes ${ }^{21}$ qual doairo vos deu Nostro Senhor e como faz de vós aver sabor os que vos veen que vós non veedes

5 e al i devedes a gradecer como vos faz antr'os boos caer e antr'os maus que ben vós caedes

II $\quad \mathrm{E} u$ vos jogaron ou u vós jogades mui ben caedes en qual destas quer

10 en falardes con toda molher ben caedes e u quer que falades e ant'el-rei muito caedes ben sequer manjar nunca tan pouco ten de que vós vossa parte non ajades

III 15 E pois el-rei de vós é tan pagado que vos seu ben e sa mercee faz d'averdes nome muito vos jaz e non seer ome desensinado. Ca pois per cort' avedes a guarir 20 nunca de vós devedes a partir un ome que vos trag' acompanhado.

Quando Joam Soares Coelho chega a Portugal no séquito de Fernando de Serpa, em 1243, a antiga proximidade entre os dois irmãos tinha-se já perdido, mas o certo é que o Infante assume, embora intermitentemente, a tenência de

21 v1015. Aparato crítico - 13. pouco rẽ - A presente edição afasta-se da de R. Lapa (1970a: 354) no verso 5, onde o filólogo considera a perda, durante a transmissão, de um «l»e, portanto, a perda do pronome «lhi» que se encontra no verso 1 ( «lhi non gradecedes / qual doairo vos deu Nostro Senhor»). Embora o erro pudesse explicar-se facilmente, a lição do manuscrito («e alhy deuedes a gradeçer») não apresenta falha nem de sentido nem sequer métrica, pelo que a mantive. No verso 8, R. Lapa emenda a lição do manuscrito «iogaron» para «jogan». Conquanto não apresente explicações, talvez tenha considerado o tempo verbal de outra ocorrência do mesmo verbo no verso («jogades») e a hipermetria de uma sílaba. Nenhuma das razões me parece suficiente para a emenda: a divergência temporal é gramaticalmente possível e é compreensível; a mínima divergência métrica não é caso único e poderia ser resolvida durante a execução musical. Mantive, portanto, a lição dos manuscritos. Também no verso 17 a integração de uma palavra («[bon] nome»), feita por R. Lapa me parece desnecessária, conforme explico ao interpretar o texto. Sem a integração de R. Lapa, este terceiro verso da terceira estrofe apresenta apenas nove sílabas métricas, em vez das dez que apresenta a maioria dos versos da cantiga. Mas este é também o caso do terceiro verso da estrofe anterior. Estas divergências poderiam compensar-se durante a performance. Em CMGP adotaram-se todas as emendas de R. Lapa. 
Tarouca $^{22}$, até às vésperas da entrada do Conde no reino. A ligação à coroa e à corte seria portanto inevitável, neste período. Posteriormente, a documentação, onde também figura Joam Soares Coelho (VenturA 2006: 82), revela-o comprometido com o partido do Conde.

Nesta cantiga, Joam Soares Coelho mostra «Don Estevan» no ambiente da corte régia, partilhando os jantares do Rei ( $\ll$ sequer manjar nunca tan pouco ten / de que vós vossa parte non ajades»); fá-lo na perspetiva de quem o observa habitualmente. Impõe-se, portanto, deduzir que esta cantiga datará de período anterior ao final de 1245. Na verdade, o que encontramos aqui referido coincide precisamente com as declarações de Vuitorom em Don Estevan diz que desamor, segundo as quais «Don Estevan» teria sido beneficiado pelo Rei, embora se queixasse de o não ser. Muito mais do que poderia esperar ser pelo Conde, cujo partido tomara, segundo dá conta, Vuitorom. Neste texto de Coelho, no entanto, não se fala ainda de partidos, nem da opção que eles implicam, o que reforça a convicção de que terá sido composto antes do final de 1245 .

Logo na primeira estrofe, encontra-se o recurso ao jogo com o verbo «ver», já observado nas cantigas anteriormente analisadas. No entanto, além de este jogo ficar reduzido a um verso e duas ocorrências do verbo, e de este não ter aqui o sentido que assume nas cantigas anteriormente analisadas (receber), somam-se-lhe outros jogos de palavras. $\mathrm{O}$ mais transversal envolve o verbo «caer», mas há também os que envolvem o verbo «jogar» e o verbo «falar», e nenhum deles tem sentido único, nem óbvio. $\mathrm{O}$ objetivo parece de resto ser, precisamente, o de adensar o sentido do texto ou mesmo torná-lo mais opaco obrigando ao esforço da decifração. Comecemos, portanto, pelo estudo deste vocabulário, antes de avançarmos para a interpretação geral da cantiga.

Dado o contexto («os que vos veen que vós non veedes»), o verbo «veer» terá, neste texto, o sentido metafórico do entendimento. Ou seja, o sujeito desta cantiga pretenderá significar que os outros compreendem as ações e intenções dissimuladas de «Don Estevan», embora este, por falta de perspicácia ou capacidade de entendimento, não compreenda que as suas dissimulações estão a ser compreendidas pelos que o rodeiam.

$\mathrm{O}$ verbo «caer» ocorre, na cantiga, associado a duas preposições - «caer antre» e «caer en»- e apenas uma vez não é acompanhado do advérbio «ben». Sabemos pela pastorela de D. Dinis Ua pastor ben-talhada (FERREIRO 2016-) que «caer antre» tem o sentido literal de cair entre um conjunto de coisas;

22 Fernandes (1970: 132) considera a tenência de Lamego e Tarouca: «É tenente de Lamego, Tarouca e vizinhas o infante D. Fernando (de Serpa)». L. Ventura refere a tenência de Lamego: «Volta de Castela por volta de 1243, assume a tenência de Lamego entre Novembro de 1243 e Setembro de 1245 e participa na guerra civil no partido contrário ao do seu irmão Sancho II » (2006: 63). 
no caso da pastora de D. Dinis, cair no chão entre flores: «E caeu antr'ũas flores. / Ũa gran peça do dia / jouv'ali, que non falava». Mas, nos versos de Joam Soares Coelho, há duas diferenças fundamentais na repetição do verbo «caer»: todas as ocorrências vêm acompanhadas do advérbio «ben», exceto uma («como vos faz antr'os boos caer»); e em todas as ocorrências acompanhadas do advérbio «ben», este precede o verbo, exceto numa («e ant'el-rei muito caedes ben»). Estas diferenças têm implicações na interpretação: «ben caer» (= cair muito) adquire sentido negativo, significando o insucesso de «Don Estevan», ao passo que «caer ben» (= ser bem recebido) adquire sentido positivo, significando o sucesso de «Don Estevan» junto do Rei. «Don Estevan» «ben cae» «antr'os maus», e é também mal-sucedido em duas situações assim referidas pelo sujeito: «u vos jogaron ou u vós jogades», «en falardes con toda molher».

A queda não qualificada entre os bons («antr'os boos caer») apenas indicia uma reação destes menos agressiva do que a reação dos maus aos quais «Don Estevan» desagradará igualmente («antr’os maus que ben vós caedes»). Mas, na verdade, a única oposição, no que respeita a «quedas» é entre o Rei, que recebe bem «Don Estevan», o Rei junto de quem este «cai ben», e todos os outros (bons, maus, os que jogam e as mulheres), que o recebem mal ou muito mal, junto dos quais «Don Eetevan» «ben cai» (= cai muito ou fortemente).

Recomenda o sujeito a «Don Estevan» que agradeça a Deus o «doairo» que lhe deu, com o qual faz «aver sabor» os que o observam. «Doairo» significa «graça, garbo, gentileza» (vASCONCELOS 199ob: 30) e, em conjunto com «sabor», ou seja, o gosto despertado nos que o observam, alude aos dotes de comportamento em sociedade, à capacidade de ser apreciado em ambiente cortês. O sentido do verbo «ver» está dependente da descrição dos atributos de apresentação em sociedade de «Don Estevan», ao mesmo tempo que denuncia a descrição destes como irónica. «Don Estevan» é observado em sociedade, onde é visto, mas não tem capacidade para ver. Ou seja, onde o entendem, mas onde não tem capacidade de real entendimento do que o rodeia. Ser visto e não ver desta forma compõe o retrato de um homem socialmente deslocado, certamente convencido de se comportar à altura do meio onde se move e incapaz de se aperceber de que assim não é. Talvez porque, como denunciado no final da cantiga, o meio onde se movia não lhe seria propriamente natural.

Mas, nesta interpretação do verbo «ver», reside a chave da ironia com que é usado o verbo «caer», quando é precedido do advérbio «ben». «Don Estevan» não tem capacidade para entender (ver) os que o rodeiam ( $\ll$ os que vos veen que vós non veedes») sendo por isso a queda tão inevitável quanto completa: «ben caedes». Em português atual, diríamos que «Don Estevan», incapaz de entender... se «espalha ao comprido». 
Quanto ao sentido de «caer ben», reservado para aludir ao efeito de «Don Estevan» junto do Rei, o texto não deixa dúvidas sobre o sentido positivo que lhe é atribuído, reafirmando e mesmo concretizando os benefícios concedidos pelo Rei ao visado da cantiga.

Quanto ao verbo «jogar», creio que devemos precisar o sentido de «zombar» ou «escarnecer» que lhe tem sido atribuído. É importante notar, em primeiro lugar, a sintaxe inusual do verbo «jogar» que, na primeira ocorrência, tem no pronome «vos» o complemento direto. O contexto da estrofe precedente, mas sobretudo o da estrofe que é introduzida pelo verso onde ocorre duplamente o verbo «jogar», aponta para o ambiente da corte. Na verdade, a própria formulação do verso - «E u vos jogaron ou u vós jogades» - invoca a interação social própria deste espaço, que na sequência da estrofe é especificada, sendo apontado o trato coloquial com as mulheres ( $\ll$ en falardes con toda molher») e logo generalizado («u quer que falades»).

$\mathrm{Na}$ Partida segunda de Alfonso X, temos um precioso apoio para o entendimento do retrato que Joam Soares Coelho se empenha aqui em fazer do diálogo social, ora entabulado por «Don Estevan» («u vós jogades»), ora entabulado por terceiros («u vos jogaron»), em contexto de corte. Fá-lo com recurso a um verbo mais específico do que parece à primeira vista, o que lhe permite uma síntese extrema.

O título IX da Partida segunda (JUAREZ BlANQUeR e RUBIO FLORES 1991: 83-102) de Alfonso X intitula-se «Qual deve el rey ser a sus ofiçiales, e a lo de su casa e de su corte, e ellos a el» e contém 30 leis, todas dedicadas aos ofícios e oficiais ao serviço do Rei. A primeira lei ( Que quiere dezir ofiçio, e quantas maneras son de ofiçiales») é introdutória e de caráter geral. A segunda («Quales omnes deve el Rey rreçebir en su casa para servirse dellos cutiana mente») concentra-se já nos homens da corte, embora mantenha o caráter geral. As leis seguintes dedicam-se a cada um dos ofícios da corte ou dos frequentadores da corte: «el capellan del Rey»; «el chanceller del Rey»; «los consejeros del Rey»; «los rricosomnes»; «los notarios del Rey», «los escrivanos del Rey»; «los mesnaderos del Rey»; «los fisicos del Rey»; «los ofiçiales del Rey»; «los despenseros del Rey»; «los porteros del Rey»; «el posadero del Rey»; «el alferez del Rey»; «el mayordomo del Rey»; «los juezes del Rey»; «el adelantado del Rey»; «la justiçia de la corte del Rey»; «los mandaderos del Rey»; «los adelantados mayores que son puestos por mano del Rey en las comarcas del Regno»; «los merinos mayores»; «el cabdillo de la nave»; «el almoxarife». A lei seguinte versa sobre o juramento a que os oficiais do Rei estão obrigados, quando assumem funções.

As duas últimas leis dedicam-se a descrever os momentos em que todas estas pessoas se encontram na corte, e a orientar o comportamento que em tais 
momentos devem assumir; especialmente, no trato coloquial. Pela importância que estas duas leis têm na determinação do sentido do verbo «jogar», na cantiga de Joam Soares Coelho, transcrevo-as aqui:

\section{Ley XXIX}

Que cosa es palaçio, e por que lo llaman asy

Palaçio es dicho en aquel lugar do el Rey se ayunta paladinamente para fablar con los omnes; e es en tres maneras, o para librar los pleytos, o para comer, o para fablar en gasaiado. E porque en este lugar se ayuntan los omnes para fablar con el mas que en otros por eso lo llaman palaçio, que quiere tanto dezir commo lugar paladino; e por ende convieneque non sean y dichas otras palabras synon verdaderas e complidas e apuestas ca asy es en juyzio que a meester que sean verdaderas e muy çiertas para librar el pleyto derechamente: e sy es en el comer deve seer conplidas segunt conviene a aquel e non ademas; ca non deven de estar muy callando, nin otrosy fablar a la oreia, nin mostrar por signos lo que quisyere dezir commo omnes de orden, nin deven otrosy dar grandes bozes; ca el palaçio en aquella sazon non a de seer muy de poridat, ca serie ademenos, nin de grant buelta, que serie ademas, porque demientre que comieren non an meester de departir, nin de rretraer nin de fablar en otra cosa, synon en aquello que conviene para governarse bien e apuestamiente. E quando es para fablar en manera de gasaiado, asy commo para departir o para rretraer, o para jugar de palabra, ninguna destas non se deve de fazer synon commo conviene: ca el departir deve seer de manera que non mengue el seso al omne por el, asy commo ensannandose: ca esta es cosa que saca mucho ayna de su siesto: mas conviene que la faga de guysa que se acresçiente el entendimiento por el, fablando en las cosas con rrazon para allegar a la verdat dellas.

\section{Ley XXX}

\section{Quantas cosas deven ser catadas en el rretraer}

Retraer en los fechos o en las cosas commo fueron, o son o pueden seer, es grant bien estançia a los que en ello saben abenir. E para esto seer fecho commo conviene, deven y seer catadas tres cosas; tienpo, e lugar e manera: tienpo deven catar que convenga a la cosa sobre que quier rretraer, mostrando por buena palabra, o por buen enxenplo o por buena fazanna otra que semeje con aquella para alabar la buena o para desatar la mala: e otrosy deven catar lugar de guysa que lo que rretrayeren que lo digan a tales omnes que se aprovechen dello, asy commo sy quisieren casti- 
gar a omne escaso diziendole enxenplos de omnes grandes, e al cobarde de los esforçados: e manera deven catar para rretraer de guysa que digan por palabras conplidas e apuestas lo que dixieren, e que semege que saben bien aquello que dizen: otrosy que aquellos a quien lo dixieren ayan sabor de lo oyr e de lo aprender. E en el juego deven catar que aquello que dixieren sea apuestamente dicho, e non sobre aquella cosa que fuere en aquel lugar a quien jugaren, mas a juegos dello, commo sy fuere cobarde dezirle que es esforçado, jugarle de cobardia; e esto deve ser dicho de manera que aquel a quien jugaren non se tenga por denostado, mas quel ayan de plazer, e ayan de rreyr dello tan bien el commo los otros que lo oyeren. E otrosy el que lo dixiere que lo sepa bien rreyr en el lugar do conviene, ca de outra guysa non serie juego onde omne non rrye; ca sin falla el juego con alegria se deve fazer, e non con sanna nin con tristeza. Onde quien se sabe guardar de palabras sobejanas e desapuestas, e usa destas que dicho avemos en esta ley, es llamado palaçiano, porque estas palabras usaron los omnes entendidos en los palaçios de lo Reyes mas que en otros lugares; e ally rresçebieron mas onrra los que las sabien: e aun lo encaresçieron mas los omnes entendidos, ca llamavan antiguamente por cavalleros a los que esto fazien, e non era syn rrazon; ca pues que el entendimiento e la palabra estranna al omne de las otras animalias, quanto mas apuesta la a e mejor, tanto es mas omne. E los que tales palabras usaran e sopieren en ellas avenir, develos el Rey amar e preçiar, e fazer mucha de onrra e de bien; e los que se atrevieren a fazer esto non seyendo sabidores dello, syn lo que se mostrarien por atrevidos e por nesçios, deven aun aver por pena seer alongados de la corte e del palaçio (JUAREZ BLANQUER e RUBio FLORES 1991: 101-102).

Como pode verificar-se, as duas últimas leis do título Ix da Partida segunda, ocupam-se, bastante logicamente, do protocolo que devem assumir os oficiais e restantes frequentadores habituais da corte, anteriormente apresentados. Como é comum a todos os protocolos diplomáticos, o objetivo é manter a cordialidade do trato, mesmo quando o conflito se encontre latente ou, especialmente, quando o conflito se encontre latente. A Lei XXIX define os objetivos habituais dos encontros: o despacho («librar los pleytos»), comer, e socializar («fablar en gasaiado»). Depois de explicar como deve ser feito o despacho, a lei explica como devem comportar-se as pessoas durante as refeições ou, mais exatamente, como e sobre o que devem falar, quando estão a comer no palácio com o Rei. Quanto aos momentos de socialização, a Lei XXIX ocupa-se apenas dos que tenham caráter mais didático 
(«departir $\left.{ }^{23}\right)$, já que os momentos cujo objetivo é a censura («rretraer») são tratados exclusivamente na Lei XXX. É ainda na Lei XXIX, no entanto, que se designa o modo considerado certo para a censura durante a socialização no contexto do palácio real: «jugar de palabra».

Dado o potencial para o conflito que a censura entre as pessoas da corte poderia ter, compreende-se que seja dedicada uma lei em separado ao protocolo para esta situação. Ou seja, para quando um oficial da corte ou alguém que nela seja admitido decida censurar outra pessoa que ali encontre. As acusações ou a censura entre as pessoas que frequentem a corte não são portanto proibidas, mas a Lei XXX chama a atenção para que têm um tempo próprio, um lugar próprio e um modo próprio.

Ao descrever o modo, o texto da lei começa com uma descrição geral, passando depois à concretização, que termina com um exemplo. Traduzo a descrição geral para melhor explicar o meu entendimento do texto da lei:

E quanto ao modo, devem ter muita atenção para censurarem usando palavras certeiras e adequadas, deixando claro que sabem do que estão a falar; também de modo a que os destinatários tenham gosto em ouvir e compreender (JUAREZ BLANQUER E RUBIO FLORES 1991: 101).

Segue-se imediatamente a concretização do modo («manera») de censurar, ou seja, a descrição de como se pode censurar alguém. É então que a designação mais geral «manera» (na sequência de tempo e lugar) é substituída pela designação mais concreta «juego». E o jogo é assim descrito:

E no jogo devem ter muita atenção, de modo a que o que digam seja dito como deve ser, e não sobre aquilo que estiver a acontecer naquele lugar com aquele a quem jogarem, mas jogando com ele, ou seja, se for cobarde diga-se-lhe que é valente, jogando-o pela cobardia; e isto deve ser dito de forma que aquele a quem joguem não se sinta atacado, mas que seja o jogo prazeroso e que se riam do jogo, tanto o visado como os outros que o ouvirem. E o que fizer o jogo deve saber rir também onde for conveniente, porque, de outra forma, não seria jogo, se ninguém se risse; uma vez que os jogos têm necessariamente de se fazer com alegria e não com fúria nem com tristeza. Donde se conclui que quem saiba evitar palavras excessivas ou desadequadas, e prefere estas de que falámos nesta lei, chamamos-lhe

23 Este verbo tem importância fundamental na cantiga Maria do Grave, grav'é de saber, de Joam Soares Coelho, estudada em Correia (2017: 112-117). 
palaciano, porque estas palavras usaram os homens entendidos nos palácios dos reis, mais do que noutros lugares e ali receberam mais honra os que as Sabiam (JUAREZ BLANQUER E RUBIO FLORES 1991: 101-102) ${ }^{24}$.

Pela descrição e pelo exemplo dado, percebe-se que se trata de usar a ironia, o humor, a boa disposição e o riso para, num contexto em que importa impedir a socialização de avançar para o conflito, fazer acusações habilmente, sem ferir suscetibilidades ou, pelo menos, deixando suficientemente a salvo a face visada ${ }^{25}$. Note-se que este texto tem com o verso de Joam Soares Coelho a afinidade de usar o verbo «jogar» do mesmo modo, ou seja, atribuindo-lhe um complemento direto. $\mathrm{O}$ contexto é também coincidente. Tal como nas leis finais do título IX da Partida segunda se trata do ambiente palaciano, da corte real; também na cantiga se alude, como se viu, a este mesmo ambiente. Parece, pois, bastante segura a dedução de que o jogo a que se refere Joam Soares Coelho no verso inicial da segunda estrofe desta cantiga é o jogo a que se refere a Partida segunda, o jogo da acusação irónica e humorística, no contexto da socialização palaciana. Esta dedução é confirmada pela sequência da estrofe onde se especificam dois momentos de conversação: um em que o interlocutor é concretizado («en falardes con toda molher») e outro em que o interlocutor é omitido ( $\ll \mathrm{u}$ quer que falades»). O resultado para «Don Estevan»é, porém, o mesmo: o insucesso («ben caedes»).

A expressão «en jogo» que substitui «jogar» com o sentido apurado, no texto da lei acima referida, ocorre também na cantiga Estavam oge duas soldadeyras, de Joam Baveca (ZILLI 1977: 166-167), onde um diálogo entre duas soldadeiras sobre as caraterísticas físicas de ambas poderá ser, ao contrário do que tem sido até agora, interpretado à luz do código explicado na Partida

24 Mantive propositadamente nesta tradução a palavra «jogo» e usei o verbo «jogar», embora atualmente não o façamos em português, para tornar mais clara a correspondência entre a utilização do verbo na lei e na cantiga de Joam Soares Coelho. Em português atual, o verbo e o substantivo mais adequados para esta tradução seria «brincar»/ «brincadeira »: «E na brincadeira devem ter muita atenção, de modo a que o que digam seja dito como deve ser, e não sobre aquilo que estiver a acontecer naquele lugar com aquele com quem se meterem, mas brincando com ele, ou seja, se for cobarde diga-se-lhe que é valente, brincando com ele pela cobardia; e isto deve ser dito de forma que aquele com quem brinquem não se sinta atacado, mas que seja a brincadeira prazerosa e que se riam da brincadeira, tanto o visado como os outros que o ouvirem. E o que fizer a brincadeira deve saber rir também onde for conveniente, porque, de outra forma, não seria uma brincadeira, se ninguém se risse; uma vez que as brincadeiras têm necessariamente de se fazer com alegria e não com fúria nem com tristeza.» (JUAREZ BLANQUER E RUBIO FLORES 1991: 101-102).

25 Não creio que o protocolo exposto nestas leis esteja diretamente relacionado com os modos de fazer sátira no âmbito da Lírica Galego-Portuguesa, como defendem Sodré (2014) e Marcenaro (2014: 50-51). Quando este livro já se encontrava no prelo, X. B. Arias Freixedo (2020: 14-20) publicou uma reflexão sobre o «jugar de palabra», em que também avalia a bibliografia anterior sobre o assunto. Concordamos em não considerar o canto trovadoresco implicado no «jugar de palavra» referido na Partida segunda. 
segunda. O texto ganha com esta leitura uma densidade e complexidade que lhe conferem um interesse acrescido. Também poderá interpretar-se no mesmo sentido o substantivo «jogador», na cantiga de João Romeu de Lugo, dedicada a Lopo Liáns, onde se referem os elogios recebidos por certa «dona», em Lugo. Os elogios parecem contrariados por Lopo Liáns, quando este diz que «já viu melhor», permitindo a interpretação de ter visto dona mais bela. Segundo esclarece a rubrica da cantiga, é a cegueira de um olho que o faz ver, no presente, pior do que via no passado, mas o remoque à dona não deixa de ser feito. Eis o jogo de palavras que merece a Lopo Liáns o elogio de João Romeu de Lugo: «foi sempre un gran jogador» (LAPA 1970: 345). Este caso, por outro lado, deixa-nos a confirmação de que a ironia, usada como exemplo de jogo de palavras na Partida segunda, não deve considerar-se o único jogo de palavras possível em contexto de socialização, havendo a considerar outros como aqueles a que aludem as cantigas de Coelho, Baveca e João, romeu de Lugo ${ }^{26}$.

Os jogos de palavras que se observam na primeira e na segunda estrofes, com a repetição dos verbos «ver», «caer», «jogar», «falar» não têm continuidade na terceira estrofe da cantiga de Joam Soares Coelho, em análise. Mas é na terceira estrofe que se encontra um termo ausente de todas as outras cantigas galego-portuguesas, incluindo as de Santa Maria. Na verdade, também não o encontrei em nenhum texto em prosa. Tanto quanto sei, trata-se de um hápax e, segundo creio, tem sido mal interpretado. Refiro-me à palavra «desensinado», que ocorre no quarto verso da terceira estrofe: «d'averdes nome muito vos jaz / e non seer ome desensinado». Neste contexto, não creio que o termo signifique, como se tem julgado, o oposto de «ensinado»; creio que significa «sem sinais», ou seja, homem sem insígnias de linhagem ou pertencente a linhagem sem insígnias, isto é, sem importância suficiente para as ter. Estas insígnias designavam-se, precisamente, «sinaes» ou «sinas» e, destas palavras, há abundantes ocorrências na prosa medieval, mas também nas cantigas de escárnio. Gil Peres Conde refere-os na sátira Non troux'estes cavaleiros aqui: «destes sinaes / que ora trage, non trouxe taes / nosco na guerra» (LAPA 1970a: 242). E Afonso Lopes de Baiam refere-os na famosa cantiga Seiaxi Don Belpelho en ũa sa maison: «Estas oras chega Johan de Froian, / cavalo velho, caçurr'e alazan, / sinaes porta eno arçon d'avan» (LORENZO GRADÍN 2008: 173).

26 «jogo»e «jogar» têm sentido diferente e associado a violência na cantiga Que muito mi de Fernan Diaz praz: «vai sobr'el e non lhi pod'escapar / e fazlhi mal jogo por ũa vez» (MARCENARO 2012: 375). O mesmo acontece na cantiga de Santa Maria 156: «Pois que ll'a lingua tallaron, / leixárono assi yr; / e mui mal lle per jogaron» (METTMANN 1986-1989: 149). O sentido estará ligado, nestes casos, à ideia de sorte e azar dos jogos com esta natureza. 
Na prosa, há referências a dois tipos de sinais: os mesmos a que se referem as cantigas de Gil Peres Conde e Afonso Lopes de Baiam, e os sinais que constituem uma assinatura. Eis um exemplo de cada uma das aceções:

E logo el rey, perante todos os altos homẽes e os alcaides do paaço que estavã enno juizo, fez leer o trellado do proceso da sua enliçon, de quando fora feito rey en Tolledo, enno qual processo e enliçon estava escripto ẽ como Paulo cõ todollos outros the fezeron menagen de o servir e a jura que todos fezeron de lhe seer leaaes e verdadeiros a elle e ao reyno. E este processo era assiinado per todos, antre os quaaes era hy o sinal de Paulo e roborado con sua mãao (CINTRA 1984, vol. 2, p. 255).

$E$ elle, quando os vio vĩir, foy muy maravilhado que sina poderia seer que cõ tã poucos vinha a elle, e demais que nom sabia que nẽhũu nobre varom tal sina tevesse (CINTRA 1990: 194).

E poseron sobr'elle hũu muy rico pano d'ouro e mãdou fazer ẽ çima do escano hũu tabernaculo muy nobremẽte obrado a ouro e azul e pintarõ en elle os sinaaes del rey dõ Afonso e os do Çide e os de dõ Ramiro, rey de Navarra, e dõ Sãcho, ifãte d'Aragõ (ibidem, p. 186).

Dada a relação com a necessidade de ter um nome, estabelecida pela sequência dos versos ( «d'averdes nome muito vos jaz / e non seer ome desensinado»), tanto um sentido quanto o outro seriam aceitáveis. Isto é: tanto poderíamos ver em «desensinado» a ideia de sem sinais indicadores de uma linhagem, como sem róbora, sem sinal indicador da identidade, do nome, precisamente. Na verdade, ambos os sentidos não se afastam grandemente, dada a circunstância de falarmos do círculo próximo do Rei. Esta interpretação da palavra «desensinado» deixa em qualquer caso esclarecida a alusão ao nome, no verso anterior, não sendo por isso, segundo creio, necessário supor a falta do adjetivo «bon» a qualificar o substantivo «nome», que R. Lapa conjeturou ${ }^{27}$. Não há na cantiga nenhuma indicação sobre a necessidade de «Don Estevan» reforçar a reputação do seu nome. Não é um bom nome (no sentido de boa reputação) que lhe falta, mas um nome, um nome à altura do espaço onde se move, já que o seu não deveria ter sido nele admitido. E só o terá sido por imposição do Rei.

27 A hipometria do verso poderia mais facilmente corrigir-se supondo um hiato onde os manuscritos apresentam uma elisão («d'averdes nome muito vos jaz»), uma vez que a perda de uma letra, que poderia até estar abreviada num dos antecedentes, é mais fácil de acontecer na transmissão textual do que a omissão de uma palavra. Mas a falta de uma sílaba poderia também ser compensada durante a performance pelo jogral, razão por que optei por manter a lição dos manuscritos. 
Com o vocabulário-chave desta cantiga esclarecido, podemos avançar para uma interpretação geral do texto. Mas recordemos antes, resumidamente, o sentido de tal vocabulário.

$\mathrm{O}$ verbo «ver» não tem, como nos textos anteriormente analisados, o sentido de «receber», mas o sentido de «entender», apoiado no sentido mais concreto de percecionar com o auxílio da visão. $\mathrm{O}$ verbo «cair», que é repetido cinco vezes entre os dois últimos versos da primeira estrofe e o quinto verso da segunda estrofe, é usado com diferenças contextuais e semânticas. Por três vezes, a forma verbal é «caedes» e é precedida do advérbio «ben» («ben caedes»). Neste contexto, o sentido é negativo: indica falhas inadvertidas, pelo menos no protocolo; quedas inconscientes no ridículo social e mal recebidas. Por uma vez, a forma verbal «caedes» é seguida do mesmo advérbio «ben» («caedes ben») e, neste caso, o sentido positivo é esclarecido abundantemente na sequência da ocorrência. Significa «agradar»e «ser beneficiado».

$\mathrm{O}$ verbo «jogar», repetido no primeiro verso da segunda estrofe, tem aqui um sentido específico. Significa o jogo social que envolve palavras, mas não só; também a atitude conducente à boa disposição e ao riso, usado em contextos político-sociais delicados, para censurar ou acusar sem melindrar, muito exigente de habilidade. $\mathrm{O}$ verbo «falar», igualmente repetido na mesma estrofe, funciona como especificador do verbo «jogar», esclarecendo de que jogo se trata, embora, repito, este jogo não se limitasse ao jogo verbal.

«Desensinado» significará sem «sinas» ou «sinaes», seja os que marcavam a pertença a uma linhagem, seja os que deixavam nos documentos a marca de um nome. Em qualquer dos casos, o termo «desensinado» será outra forma de dizer o que o verso anterior diz, conforme já indiciava a sintaxe, ou seja, que à personagem «Don Estevan» faz falta («muito vos jaz») um nome, simbolizado nos referidos $\ll$ sinaes $\gg$ ou $\ll$ sinas $\gg$.

Considerando o entendimento do vocabulário, tal como acima exposto, podemos começar a interpretação geral da cantiga por outro verbo, igualmente repetido, cujo sentido, embora não apresente dificuldades, tem sentido irónico: agradecer. Quase toda a primeira estrofe é dedicada à opinião do sujeito, segundo a qual «Don Estevam» deveria dar graças a Deus pelos dotes sociais («doairo») que proporcionam grande prazer ( «sabor $»)$ a todos os que o rodeiam. Sabemos que é uma declaração irónica, porque «Don Estevan» é visto pelos que o rodeiam e se divertem a observá-lo, mas não tem capacidade para os ver, isto é, para entender quem o rodeia e provavelmente para entender o tipo de prazer que causa em quem o rodeia («como faz de vós aver sabor / os que vos veen que vós non veedes $\gg$ ). Mas o sujeito considera haver mais a agradecer a Deus: a queda junto de «bons», cujo desagrado seria manifestado de forma menos contun- 
dente; e a queda junto de maus, cuja reação ao «doairo» de «Don Estevan» seria menos benigna.

A partir do último verso da primeira estrofe, o sujeito da cantiga deixa de referir o agradecimento devido a Deus e concentra-se na enumeração de todos os momentos e aspetos do insucesso social («ben caedes») de «Don Estevan», que os dois últimos versos da primeira estrofe resumem com aparente paradoxo, clara ironia e provável efeito cómico: «como vos faz antr'os boos caer / e antr'os maus que ben vós caedes».

É na segunda estrofe que Joam Soares Coelho desenha com mais pormenor a presença social de «Don Estevam», com recurso aos verbos «jogar»e «falar» e com recurso às figuras femininas. Não devemos esquecer que o verbo «jogar», na aceção em que é usado nesta cantiga, significa censurar com habilidade. Sendo «Don Estevan» inábil no jogo social, dever-se-á encontrar neste retrato a figura de um homem cuja censura generalizada, mais especificamente às mulheres, é mal disfarçada.

No bom acolhimento que o Rei dispensa a «Don Estevan», contrariamente a todas as outras pessoas referidas na cantiga (bons e maus), é impossível não encontrar um prolongamento da sátira de que é alvo o próprio «Don Estevan». Não apenas por ter relativamente a «Don Estevan» uma cegueira que mais ninguém, nos espaços frequentados por ele, parece ter: nem os que o «veem» sem «serem vistos» por ele (estrofe I), nem os que com ele socializam (estrofe II). O Rei é subtilmente censurado por, ao contrário do que se esperaria dele, valorizar uma pessoa incapaz de dominar o jogo social. Fazendo-o, o Rei assume de resto comportamento contrário ao que é recomendado na Lei XXX do título IX da Partida segunda de Alfonso X:

E los que tales palabras usaran e sopieren en ellas avenir, develos el Rey amar e preçiar, e fazer mucha de onrra e de bien; e los que se atrevieren a fazer esto non seyendo sabidores dello, syn lo que se mostrarien por atrevidos e por nesçios, deven aun aver por pena seer alongados de la corte e del palaçio (JUAREZ BLANQUER e RUBIO FLORES 1991: 102).

Eis a razão por que os favores descritos na parte final da cantiga de Joam Soares Coelho contêm mais uma censura dirigida à escolha do Rei do que à incapacidade de «Don Estevan» para se comportar em ambiente palaciano: em vez de afastar quem tem um comportamento inadequado, recebe-o e valoriza-o, demonstrando falta de discernimento.

$\mathrm{Na}$ terceira estrofe, a sátira a «Don Estevan» é especialmente ácida e visa já não o comportamento desta figura, mas o nascimento ou a linhagem dela, que, na verdade, serve de justificação àquele. A censura ao Rei permanece, e mantém 
a subtileza ${ }^{28}$. Quando o sujeito afirma que «Don Estevan» deve corresponder aos benefícios recebidos encontrando para si um nome à altura, denuncia a atribuição pelo Rei de benefícios sem justificação aceitável; denuncia a inversão de uma ordem natural: já não vem o nome antes dos benefícios; no tempo presente, o Rei primeiro concede, devendo os agraciados corresponder depois encontrando um nome à altura. A sátira de Coelho assume aqui outra direção: o acolhimento por Sancho II no seu círculo próximo de quem não o merece; por um lado, por não saber comportar-se, uma vez que não domina os códigos de socialização, por outro, por não dispor das credenciais necessárias para tal.

Esta crítica ao Rei, o perfil de «Don Estevan» aqui desenhado e a datação anteriormente proposta para esta cantiga apontam para que se trate, neste texto, de uma reação à eleição, por influência de Sancho II $^{29}$, de Joam Viegas de Portocarreiro para arcebispo de Braga, em 1244. Parecendo uma sátira pessoal, pelo contrário, esta cantiga é um raro testemunho do isolamento de Sancho II na sua corte, no ano que precedeu a deposição. Joam Soares Coelho, no séquito do Infante de Serpa, viria a tomar o partido do conde de Bolonha, mas este olhar crítico sobre a escolha do Rei para um dos lugares de exercício do poder no reino mostra que ambos se manifestavam já contra Sancho, antes de 1245.

A datação precoce (1244), coincidente com a eleição de Joam Viegas de Portocarreiro para arcebispo de Braga e a declaração de Coelho, nesta cantiga, de que, dada a necessidade de circular pela corte, deveria «Don Estevan» assumir outro nome ( $«$ E pois el-rei de vós é tan pagado / que vos seu ben e sa mercee faz / d'averdes nome muito vos jaz / e non seer ome desensinado ») conduz a pensar que aqui se encontra o início do conjunto satírico dedicado a «Don Estevan». Ou seja, que teria sido Coelho, nesta mesma cantiga, a trocar o nome de Portocarreiro pelo nome de um seu antecedente no arcebispado - Estêvão Soares, D. Estêvão - que, ao contrário do de Portocarreiro e mesmo de Silvestre Godinho seu antecessor imediato, invocava prestígio, poder, tanto na hierarquia clerical quanto laica; e peso linhagístico. Relembro que o arcebispo Estêvão Soares se destacou precisamente pela ação diplomática em ambas as hierarquias (clerical e laica) tendo conseguido o que quis junto do Papa, de reis e do próprio Sancho II, em diversas ocasiõe ${ }^{30}$. A substituição do nome de um inábil (Joam Viegas de Portocarreiro) pelo nome de «Don Estevan» seria, portanto, especialmente irónica. $\mathrm{O}$ facto de D. Estêvão Soares ter herdado a alcunha do pai

\footnotetext{
28 As críticas ao Rei, segundo Tavani e Lanciani, não são comuns na Lírica Galego-Portuguesa (LANCIANI e TAVANI 1995: 156).

29 Sobre a eleição de prelados e a eleição específica de Joam Viegas de Portocarreiro, consulte-se o capítulo «Enquadramento histórico».

30 Consulte-se o perfil deste Arcebispo no capítulo «Enquadramento histórico».
} 
(o Torto), ou seja, pessoa com défice de visão, facilitava as acusações de «cegueira» a Joam Viegas depois de renomeado «Don Estevan».

$\mathrm{O}$ gosto de Coelho pelas substituições de nomes por outros nomes e a experiência que tinha com este jogo literário torna a possibilidade ainda mais plausível. Lembre-se que o caso da Ama, em que a substituição de nome tem contornos diferentes (um nome pela tradução latina do mesmo nome) e contexto literário diferente (cantiga de amor), tinha tido início no ano anterior, em Castela.

Mas o recurso a outro nome não bastará a «Don Estevan» para se movimentar na corte, junto do Rei. O sujeito complementa portanto a solução de trocar de nome oferecendo a «Don Estevan» um último conselho: que nunca se afaste do homem que o acompanha («nunca de vós devedes a partir / un ome que vos trag'acompanhado»). Este curto retrato de dependência extrema, de alguém que, em momento algum, pode afastar-se de quem o serve e, portanto, lhe é inferior, mostra também a incapacidade de «Don Estevan» para o lugar diplomaticamente exigente que ocupa, e a incapacidade do Rei para escolher. $O$ facto de $o$ capelão de Joam Viegas de Portocarreiro também se chamar Estêvão ${ }^{31}$ poderá ter reforçado o jogo e o efeito cómico da substituição do nome. 


\section{Joam Soares Coelho}

I 1 Don Estevan fez sa partiçon ${ }^{32}$

con seus irmãos e caeu mui ben

+++++++++++++++++++++ on

en Lisboa e mal en Santaren

5 mais en Coimbra caeu ben provado:

caeu en Runa ata eno Arnado

en todos tres os portos que i son.

II Quen diz d'Estevan que non vee ben

digu'eu que mente ca diz mui gran falha

10

e mostrar-lh'-ei que non disse ren

nen é recado que nulha ren valha

pero mostrado devia seer

ca non pode per nulha ren veer

mal ome que non vee nemigalha.

15 Quen lho disse sei que tho non diria

ca vee mal, se migo falass'ante

ou se o viss'andar fora da via

como o eu vi en, junt'a Amarante

que non sabia sair dun tojal

20 por én vos digo que non vee mal

quen vee derredo quanto deante.

V1014 Aparato crítico - 15. Equen 18. comou eu ui encũta 20. ues mal 21. quante - R. Lapa (1970a: 353) emenda o verso 7 em dois pontos («en tôdolos três portos que i ten»), apresentando justificação apenas para a alteração da palavra em rima ( $\ll$ A rima exige em absoluto uma forma, que dificilmente poderá deixar de ser ten»). Nenhuma das emendas feita por R. Lapa neste verso é necessária. A construção «en todos três os portos que i son» é enfática e tem paralelo por exemplo nos seguintes passos do Livro de linhagens do conde D. Pedro e da Demanda do Santo Graal respetivamente: «E estos condes todos sete jazem em Sam Pedro d'Aatei» (MATTOSO 1980, vol. II/1, p. 268); «que tal foe sua ventuira que em todos quatro dias nom achou u se acolhesse» (PÍEL 1988: 155). CMGP adotou apenas a primeira emenda de R. Lapa («em tô[d]olos três portos »). Na edição de R. Lapa, foram feitas duas integrações com o objetivo de regularizar os versos: uma no verso 1 (fez $[\mathrm{o}]$ ), adotada por CMGP, e outra no verso 10. Neste, R. Lapa integrou, logo no início, a palavra «ar» («e $[\mathrm{ar}] \gg)$, ao passo que em CMGP preferiu-se integrar, no mesmo lugar do verso, a palavra «eu» («e [eu] »). Não há, no entanto, nenhuma indicação de falta de uma palavra neste lugar do manuscrito. A recuperação de uma sílaba poderia passar pela consideração de um hiato em vez de uma elisão, onde o manuscrito a mostra («mostrarlhey») e onde o copista poderia facilmente ter omitido uma letra, na sequência de duas iguais. Mas a hipometria e a hipermetria por uma sílaba são comuns nestes textos e poderiam ser compensadas durante a performance. Na presente edição, foi por isso mantida a lição dos manuscritos. No verso 11, R. Lapa emenda para «nen á recado», considerando: «Também deverá ser erro, por nen á recado $=$ nem 
Esta cantiga de Joam Soares Coelho foi transmitida apenas pelo Cancioneiro da Vaticana (v), cujo copista, ao mudar de página, se terá enganado no verso em que deveria continuar a cópia (talvez porque os dois versos começassem com a mesma palavra: «en») e saltou o verso três, que assim se perdeu. $O$ facto de, na primeira estrofe, o último verso rimar com o primeiro e o segundo versos ( $\mathbf{a b}(\mathbf{a})$ bcca), ao contrário do que acontece nas estrofes II e III (ababccb), em que o último verso rima com o segundo e o quarto, poderia fazer-nos duvidar da integridade da cantiga ${ }^{33}$. Na verdade, este facto e a ausência do terceiro verso poderia até levar-nos a pensar ter a primeira estrofe um esquema métrico-rimático suficientemente diferente para a considerarmos autónoma das outras estrofes ${ }^{34}$. No entanto, tendo a perda do terceiro verso uma explicação na mecânica da cópia e não sendo a divergência rimática caso único, há diversos fatores de unidade entre as três estrofes que pesam no sentido contrário.

No plano formal, devemos notar que as três estrofes estão unidas por uma grande oscilação métrica entre as nove sílabas e as onze, se não considerarmos nenhuma sinalefa, nem nenhuma falha dos copistas na transmissão dos encontros vocálicos. Mas há uma notável regularidade dentro da irregularidade: embora haja, em todas as estrofes, articulação de versos masculinos (terminação em sílaba tónica) e femininos (terminação em sílaba átona), a localização

tem inteligência, ponderação». A intervenção não se justifica e já CMGP recuperou a lição do manuscrito. No início do verso 15 , o copista escreveu a palavra «quen», mas com a inicial maiúscula «E» («Euen»). No entanto, entre o $\ll \mathrm{E} \gg$ e o $\ll \mathrm{u} \gg$ deixou uma letra borrada que se parece com o início de um $\ll \mathrm{q} \gg$ minúsculo. Esta intervenção dá conta de hesitação na interpretação de uma maiúscula do antecedente, razão pela qual emendei a lição do manuscrito substituindo apenas a letra inicial «E» pela letra «Q»: «Quen lho disse». Monaci (1875: 350 ) leu, a seguir à inicial um «m», embora considerasse: «la prima asta della $\mathrm{m}$ pare cancellata». Não me parece que o conjunto a que se refere possa tratar-se de uma letra só. R. Lapa (1970a: 353) emendou o passo para «E se lho diz» afastando-se, sem explicações nem necessidade, da lição do manuscrito, que é recuperada em CMGP. Aqui, no entanto, inexplicavelmente, mantém-se a emenda de R. Lapa que envolve a substituição do tempo verbal: «E quem lho diz». R. Lapa, no mesmo verso, emenda também, sem justificação, a segunda ocorrência de «lho» para «lhe», no que é seguido em CMGP. No verso 17 , a elisão apresentada pelo manuscrito («vissandar»), e aqui mantida, foi eliminada por R. Lapa, que, sem justificação, recuperou o hiato («visse andar»). Em CMGP adota-se a mesma emenda. A lição do manuscrito para o verso 21 («quãte»), mantida pelos editores anteriores («quant'é»), não faz sentido aceitável (vê atrás o que está à frente). Considerei, portanto, uma troca pelo copista de um «0» por um «e». A emenda que recupera o «o» deixa o verso com o mesmo sentido expresso ao longo do texto: «Don Estevan» vê tanto à frente quanto atrás, ou seja, não vê nada.

Note-se, porém, que este não é caso único na Lírica Galego-Portuguesa. Uma consulta do Repertorio metrico della lirica galego-portoghese (TAVANI 1967b) permite rapidamente apurar que outros trovadores optaram por muito semelhantes divergências rimáticas. Por exemplo, Alfonso X, na cantiga Ao dayan de Cález eu achei, usa o esquema ababcca para a estrofe v, e o esquema ababccb para as estrofes I a IV. Pero da Ponte usa, na cantiga $O$ muy bon rrey que conquis a fronteyra, o esquema ababcca para a IV estrofe e o esquema ababccb para as estrofes I a III.

34 É o que se considera em CMGP, onde a primeira estrofe é tratada como uma cantiga incompleta, e as estrofes seguintes como uma outra cantiga. Eis a justificação apresentada, que me parece insuficiente: «Uma análise sumária da razom das peças comprova-o facilmente». 
dos versos femininos em cada uma das estrofes é sempre diferente. De facto, na estrofe I, os versos femininos são os de rima c; na estrofe II, os versos femininos são os de rima b; na estrofe III, são os de rima a e b. Não creio que este ponto de ligação entre as três estrofes seja fruto do acaso, nem creio que a irregularidade métrica que se observa na cantiga, dada a relativa consistência, seja o resultado de um defeito de transmissão ou seja alheia à perdida face musical da cantiga. Por esta razão me abstive de todas as emendas que visassem a isometria dos versos.

Do ponto de vista temático, é evidente que as duas últimas estrofes estão unidas pelo assunto que desenvolvem, assente aliás na repetição do verbo «ver». No entanto, como vimos na análise da cantiga anterior, o verbo «ver» e o verbo «caer» podem relacionar-se na sátira a «Don Estevan». Há, além disso, uma insistência na toponímia que, embora seja mais intensa na primeira estrofe (Lisboa, Santarém, Coimbra), ressurge na última estrofe (Amarante). É certo que tem aqui sentido diverso, como veremos, mas tem igualmente um aspeto em comum.

Finalmente, como também se verificou na cantiga analisada anteriormente, cuja última estrofe dispensa os jogos verbais com «cair», «ver», «jogar» etc. que encontramos nas estrofes anteriores, Joam Soares Coelho nem sempre evidencia os nexos semânticos entre as estrofes, especialmente nas cantigas de escárnio. Poderemos aliás dar outros exemplos, como a cantiga contra Vuitorom Don Vuitoron, o que vos a vós deu, cuja última estrofe parecia, até há pouco tempo, de tema completamente alheio ao tema das estrofes anteriores ${ }^{35}$.

A todas as razões já indicadas para considerarmos as três estrofes como pertencentes à mesma cantiga, devemos acrescentar o facto de o testemunho manuscrito único do texto não dar nenhuma indicação de se tratar de duas cantigas ou de ter havido falha na separação de dois eventuais textos. No cancioneiro v, onde as cantigas não receberam numeração própria, esta não é exceção, mas o início de novas cantigas é habitualmente assinalado por um espaço de intervalo. Neste caso, nenhum espaço separa a primeira da segunda estrofes; nenhuma perturbação na cópia indicia ter havido deturpação na transmissão.

Creio, portanto, haver mais motivos para considerarmos pertencerem as três estrofes à mesma cantiga do que a duas diferentes e, neste pressuposto, tratarei de a interpretar.

35 De forma um pouco sibilina, Coelho acusa Vuitorom, na primeira estrofe desta cantiga, de este lhe ter roubado cantigas. Nas duas últimas estrofes da cantiga, o tema é a usurpação de comendas. Antes de se ter compreendido a acusação de «plágio», o nexo temático passou despercebido (CORREIA 2017: 52-53, 86-88). 
Como anteriormente, será conveniente concentrarmo-nos no esclarecimento de algum vocabulário e, neste caso, também do significado da toponímia mencionada, antes de avançarmos para um comentário geral do texto.

Começaremos pela palavra «partiçon», que ocorre logo no primeiro verso. O sentido mais comum que assume é o de «partilhas» em contexto de herança. Mas, como acontece a muito vocabulário da jovem língua portuguesa, nesta época, também a palavra «partiçon» é polissémica. Em contexto bélico, é usada para designar a repartição de despojos de guerra. Vejam-se alguns exemplos colhidos na prosa medieval portuguesa:

- Senhor, todo o aver que vós e nós os filhos d'algo avemos d'aver desta batalha, convem a saber o que está dentro no curral, seja todo dos reis d'Aragon e de Navarra. E a vós, senhor, dou a honrra da batalha que a vós he devida. E todo o aver que he de fora do curral, todos os que o ouveró que o logre cada hũu como o percalçou.

E el rey teve que dizia mui ben e confirmou o que el fezera. E outrossy os reis d'Aragon e de Navarra teveron que dom Diego fora muy discreto en fazer esta partiçon e que soubera muy ben guardar a hõrra del rey dom Afonso. E assi foron todos contentes do que dom Diego mandou (CINTRA 1990: 336).

$E$, desque foron assessegados, mãdou ajũtar todo o aver que fora achado ẽno castello e outrossy todo o que trouxera dõ Alvaro Fernandez e disselhe:

- Coyrmãao, tenho por bem que, de todo esto, vós tomedes o quinto, ca o merecedes muy bẽ.

Dom Alvaro Fernãdez gradeceulho muyto e nõ o quis tomar. E disse ao Cide:

- Vos avedes esto mays mester pera mãteervos e nos.

E, despois que todo foi partido, o Cide mandou dizer a el rey que assy sabya ellle desservyr senhor. Muy bem pagados foron os do Cide da sua partiçõ. Mas elle nõ avya a que vender o seu quinto; e mandou dizer aos mouros dos logares donde forõ aquelas cousas que thas vehessem comprar. E os mouros prouguelhe dello muyto e veheromlho cõprar. E deronlhe por o seu quinto tres myl marcos de prata por os cativos e por os gaados. E pagaronlhe todo em tres dias. E deste roubo forom todos muy ricos (CINTRA 1984, vol. 3, p. 425).

Estas palavras forom por razom da partiçom das cousas que gaanharom na lide que o ifante dom Afonso, filho d'el rei dom Fernando houve em Eixerez 
com el rei Abuec e com outros reis mouros, na qual lide foi gaanhado mui grand'algo. Este dom Alvar Pirez havia de partir esta cavalgada, e, porque se nom partia aa sa vontade com os de dom Gonçalo Rodriguez, disse-lhe dom Gonçalo Rodriguez na partiçam d'el rei que era fantasma nas lides, que levava a nomeada e nom fazia rem por o corpo. Esto lhe dizia el porque dom Alvar Pirez era mui gordo e nom podia sofrer armas nem ũas, como quer que el fosse muito aventuirado nas fazendas e de boo esforço. E ũu seu vassalo, de dom Alvar Pirez, que chamarom dom Fernam Goterrez, disse a dom Gonçalo Rodriguez que mentia (MATTOSO 1980, vol. II/1, p. 236).

Na Lírica Galego-Portuguesa, o vocábulo «partiçon» ocorre em duas cantigas e em nenhuma tem o sentido de partilha no contexto de herança. $\mathrm{Na}$ cantiga Partir quer migo mha madr'oj'aqui, de Juião Bolseiro (COHEN 2003: 413), diz o sujeito feminino que a mãe pretende dividir com ela tudo o que tem no mundo («quant'á no mundo»), a saber: o namorado de ambas («de vós, amig', ũa parte») e todos os haveres e boa-vontade da mãe («e faz m'outra de quant'á e de si»). Na cantiga Don Foão, en gran cordura, de Pedro Amigo de Sevilha (LAPA 1970a: 457), refere-se um «Don Foão» que, por meio de «preitesia» (ação legal), quis fazer uma «partiçon» com Pedro Amigo de Sevilha, o que este recusou. Embora não saibamos quem seja «Don Foão», não parece tratar-se, também neste caso, de uma relação familiar que pudesse dar origem a partilha por razão de herança. $O$ âmbito semântico da palavra é, portanto, bastante menos estreito do que poderia parecer à primeira vista.

No contexto da guerra civil, os Portocarreiro dividiram-se entre os dois partidos em conflito chegando a achar-se frente a frente nos dois lados da barricada. Em junho de 1245, Joam Viegas de Portocarreiro, arcebispo de Braga, ainda se faz acompanhar ao Concílio de Lião por Fernam Anes de Portocarreiro, cónego de Braga, reitor da igreja de Santa Maria de Torres Vedras e capelão de Octaviano Ubaldini (VENTURA 2006: 65, 69, 70), além de primo do Arcebispo. Mas a partir desta data, a família divide-se. No Juramento de Paris, estarão Joam Viegas de Portocarreiro e o irmão, Gomes Viegas de Portocarreiro. Raimundo Viegas de Portocarreiro, outro irmão, será o responsável pelo rapto da rainha D. Mecía Lopes de Haro. Quando o Rei expulsa o bispo D. Tibúrcio de Coimbra ocupando a cidade durante 18 meses, entre 1246 e 1247, um dos seus homens, nesta ação, foi Gonçalo Anes de Portocarreiro, primo de Joam Viegas e irmão de Fernão Anes, que também acompanhou o Rei até ao exílio em Toledo (ibidem, p. 75, 80, 81). Pero Anes de Portocarreiro, primo de Joam Viegas e tenente de Parada, manteve-se fiel ao Rei e no seu posto de tenente até 1248 . Os dois irmãos cuja des- 
cendência se dividiu pelos dois partidos foram Egas Henriques e Joam Henriques. O primeiro foi pai de Joam Viegas, de Gomes Viegas e de Raimundo Viegas, que não só assumiram o partido do Conde como assumiram tarefas específicas com o objetivo de facilitar a tomada do poder. O segundo foi pai de Fernão Anes, de Gomes Anes e de Pero Anes, que se mantiveram fiéis ao Rei.

Considerando o contexto de composição das sátiras a «Don Estevan», podemos ver em «partiçon» uma alusão à repartição de tarefas de apoio a Afonso entre os irmãos do arcebispo de Braga. Sem perder de vista que o vocabulário usado invoca a situação de herança e, portanto, neste caso, as consequências das posições assumidas ${ }^{36}$, devemos ponderar, no entanto, outra possibilidade: a de que a palavra «irmãos» seja o resultado de uma deturpação, durante a cópia, de «coirmãos» (primos). Considerando que o substantivo está precedido de «seus» e que tanto «us» quanto «co / con» poderiam abreviar-se com o mesmo sinal (uma espécie de nove) (MONACI 1875: 448), é possível que um copista se tenha, a certa altura da transmissão, convencido de ter havido duplicação acidental desta abreviatura e tenha eliminado uma delas. O verso teria, portanto, não nove sílabas, mas dez sílabas, medida métrica mais frequente na cantiga. De acordo com esta possibilidade, haveria neste texto alusão à separação dos primos Portocarreiro entre o apoio a Sancho II e o apoio ao Conde.

Uma destas possibilidades, acrescida das referências toponímicas coincidentes com a toponímia do conflito, implica o entendimento de que esta cantiga, embora retome alguns dos jogos de palavras da cantiga de Joam Soares Coelho, anteriormente estudada, tenha sido composta depois da eclosão do conflito e das inevitáveis tomadas de partido.

Na primeira estrofe, voltamos a encontrar, como na cantiga anterior, o políptoto com o verbo «caer» e, como ali, encontramo-lo acompanhado do advérbio «ben». No entanto, enquanto na cantiga anterior se faz referência ao grupo dos «bons» e dos «maus», nesta cantiga, ao advérbio «ben» contrapõe-se o advérbio «mal». «Don Estevan» «caeu mui ben» (foi bem recebido) e «caeu mal» (foi mal recebido), além de simplesmente ter caído («caeu»), o que, como vimos também na análise à cantiga anterior, significa que «Don Estevan» foi mal-sucedido, ou simplesmente caiu em desgraça. Por outro lado, enquanto na cantiga anterior todas as referências apontavam para o espaço da corte e um

36 Veja-se o seguinte passo do Livro de linhagens do conde D. Pedro (мAтTOso 1980, vol. II/2, p. 102): «E estes todos se chamarom de Barvudo porque eram d'i naturaes e haviam i peça d'herdades em que cairom, porque o couto de Belmir caio em a partiçom a Martim Pirez, que casou com dona Sancha Martiiz, filha de dom Martim Fernandez de Riba d'Avizela, e deu-lhe este couto de Belmir em doaçom por compra de seu corpo. E por todas estas maneiras se nom chamarom de Belmir, mais chamarom-se de Barvudo». 
momento anterior à guerra civil, nesta cantiga, como já referido, a toponímia e outros elementos apontam para período subsequente à eclosão do conflito.

Antes da chegada do Conde, quando o reino está mergulhado em profunda insegurança devido à não aplicação da justiça, as três cidades referidas nesta cantiga são consideradas as mais seguras (FERNANDES 2010: 286). Durante a crise de 1245-1248, Coimbra foi a cidade do Rei e dos seus fiéis, enquanto Lisboa foi por onde o Conde entrou no reino, para executar a bula papal onde se exortava todos a prestarem-lhe fidelidade, homenagem e juramento. Santarém deverá ter sido cedida logo a seguir (VENTURA 2006: 78), tal como Leiria, que, entre 1246 e 1247, foi o quartel-general de Afonso. O bispo de Coimbra, D. Tibúrcio, que juntamente com o arcebispo Joam Viegas de Portocarreiro foi executor da bula de deposição de Sancho II, tem de se refugiar em Santarém e Leiria, acabando por morrer em novembro de 1246 (ibidem, p. 73).

A perda do terceiro verso impede-nos de saber onde foi bem recebido $\ll$ Don Estevan» («caeu mui ben») e o que terá acontecido em Lisboa, mas, em Santarém, diz Coelho que «Don Estevan» «caeu mal», ou seja, foi mal recebido, e que, em Coimbra, «caeu». O advérbio que se segue («ben») modifica o adjetivo «provado» que termina o verso: «caeu ben provado» significa, portanto, que «Don Estevan», em Coimbra, «caiu» com toda a certeza, sem réstia de dúvida ${ }^{37}$.

O jogo de Coelho com o verbo «caer» nesta cantiga tem semelhanças com o que faz na cantiga anterior: embora crie a aparência de uma oposição, na verdade, o que diz vai no mesmo sentido: em Santarém foi mal recebido (caeu mal) e em Coimbra foi, sem dúvida («ben provado»), mal-sucedido, tendo caído em desgraça («caeu»), o que aconteceu depois de ter feito «partiçon con seus irmãos» (ou coirmãos, isto é, primos). O insucesso em Coimbra é especificado logo a seguir com recurso a topónimos da cidade, precedidos da forma verbal desacompanhada do advérbio: «caeu en Runa ata eno Arnado / en todos tres os portos que i son.»

Runa e Arnado pertencem à toponímia de Coimbra e indicam um itinerário que «Don Estevan» terá percorrido e onde a vida lhe correu mal: em Coimbra, desde Runa até ao Arnado, «Don Estevan» foi mal-sucedido, caiu em desgraça.

37 Nas Cantigas de Santa Maria, esta sequência de adjetivo e advérbio ocorre em várias cantigas: «Mas um dia sinaado / en que Deus quis encarnar, / o convento foi levado / de comer, e a rezar / se fillaron ben provado / por aa eigreja passar» (METTMANN 1986-1989, vol. 1, p. 276-277); «mas foron y falecer, / ca esto foi ben provado / que por ferir nen tanger / sol sinal non foi mostrado.» (ibidem, p. 303); «Log'a madre do moço convidou de bon grado / a moça e ssa madre, e mandou ben provado / guisar de comer toste; e o jantar guisado» (ibidem, vol. 2, p. 331). 
A Runa, em Coimbra, era um curso de água, onde existiram «Banhos régios», que desaguavam no Mondego: «O percurso da torrente dos Banhos Régios entre a praça de 8 de Maio e o rio era conhecido, pelo menos desde o século XII, pelo nome de runa» (ALARCÃO 2008: 15).

Em 1200, o papa Inocêncio III faz uma inquirição na sequência de uma queixa dos bispos de Coimbra a respeito de uma usurpação de direitos pelo mosteiro de Santa Cruz. No âmbito desta inquirição, este topónimo é mencionado:
[...] quando fecerunt fratres Sancte Crucis capellam Sancti Johannis cui dedit dominus rex suum ortum pro faciendum parrochia et erat terminus ejus contra Sanctam Justam runa sicut currit ad Mondecum et per pontem ejusdem runa sicut vadit per ruam de Montem Rubeum ${ }^{38}$.

Quanto ao Arnado, trata-se de zona em Coimbra junto ao rio Mondego, documentado já em meados do século XII: «Em 1140, o prior da Sé aforou aos irmãos Paio e Miguel uma casa justa nostra almuniam in illo Arnato de flumen Mondeci (LP., n. ${ }^{\circ} 311$ ), "junto da nossa almuinha no arnado do rio Mondego" » (ibidem, p. 183). Na verdade, há notícia, cerca de um século depois dos acontecimentos políticos que servem de cenário a este conjunto satírico, de casas do Rei numa rua situada precisamente entre a Runa e o Arnado:

No Livro do Almoxarifado de 1395 registam-se casas do rei na rua da Moeda, «a qual rua se começa no arnado de Coimbra e se vai derecta afinir na rua que vem do spital pera auga de runa» (ibidem, p. 187).

Em todo o caso, sendo espaços junto ao rio, serão provavelmente espaços afastados do palácio real, situado na parte alta da cidade, mas espaços próximos quer da Sé de Coimbra, quer do mosteiro de Santa Cruz, como aliás os referidos documentos dão conta ${ }^{39}$, embora também por ali haja os banhos régios e casas do Rei.

Na primeira estrofe da cantiga em análise, Coelho mostra, portanto, «Don Estevan» em percurso por Coimbra, cidade que o Rei dominou até se retirar para Toledo, apesar de o seu bispo, D. Tibúrcio, ter sido um dos executores da bula que o depôs, o que lhe custou a expulsão da cidade. Mas o percurso em

$38 \ll[\ldots]$ quando os frades de Santa Cruz edificaram a capela de S. João à qual o senhor Rei deu a sua almuinha para que se fizesse a paróquia, e o limite desta, do lado de Santa Justa, seguia pela runa que corre para o Mondego e pela ponte dessa mesma runa que vai pela rua de Montarroio» (ALARCão 2008: 284).

«Nesses primeiros dias de Janeiro de 29, no palácio do Rei em Coimbra, na parte alta da Cidade, bem acima da quase ribeirinha Santa Cruz e da Sé, situada em plena medina, aí onde morava tradicionalmente, desde o período islâmico, o poder político, na qasaba, a alcáçova, Sancho reuniu com toda a solenidade a sua Cúria» (FERNANDES 2010: 214). 
Coimbra a que se refere Coelho é especificamente junto ao rio, o que poderá ser invocador da Sé e do mosteiro de Santa Cruz. A referência no último verso a três «portos» deve fazer-nos refletir sobre o significado desta palavra.

Acerca da distância entre a Runa e o Arnado de Coimbra, diz J. Alarcão o seguinte: «Dificilmente podemos admitir três portos no curto trecho entre a runa e o Arnado» (ibidem, p. 182). Na verdade, não creio que se fale aqui de portos fluviais, que, neste caso, teriam de implicar a possibilidade de navegar um braço do rio Mondego e, com J. Alarcão, estranhar a existência de três portos em curta distância do referido braço de rio. Sobretudo, teríamos de admitir o insucesso («caer») de «Don Estevan» nos referidos três portos do referido braço do rio Mondego, no centro urbano de Coimbra. Não faz sentido.

A palavra «porto» não teve, no entanto, apenas o sentido que hoje comumente lhe atribuímos de lugar marítimo, fluvial ou lacustre onde as embarcações podem encostar para mais facilmente conseguirem acesso a terra, e proteção. A palavra significou também passagem entre montanhas; elevação na serra e território serrano. Vejam-se alguns exemplos do uso do termo com este sentido, por exemplo, na Crónica geral de Espanha de $1344^{40}$ :

Outrossi algũus dos cidadãaos de Leom tomarom ho corpo de Sã Fruylhano e levarõno ataa os mõtes Perineos, que som os portos d'Espanha, a par do spital de Roçavalles; e poserõno hy ẽna igreja de Sam Joham Bautista. (CINTRA 1984, vol. 3, p. 179).

E este, con grande brio, passou o mar e veo en Espanha e chegou en Sevilha e foy pella campina de Cordova e passou o porto do Muradal (CINTRA 1990: 308-309).

E el rey dom Afonso mandou a Lopo Diaz e a Martin Anes e a Sueiro Fernãdez que fossen açima ao porto e mandou cõ elles muita companha. E elles, quando foron en çima da serra, acharon la dez mil cavaleiros d'Alarves e feriron en elles mui esforçadamente, de guisa que os fezeron decender da serra. E, logo en outro dya, cavalgarõ os reis e chegaron con sua hoste ao pee do Muradal. E logo en outro dya sobiron os reys ao porto e ficaron hi suas tendas. E, en esse dia, tomaron logo o castello de Ferral. A fundo desse castello ha muy maaos caminhos e vales muy streitos e fortes (ibidem, p. 325).

R. Lorenzo (1977), no glossário de La traducción gallega de la Crónica General y de la Crónica de Castilla, considera ambos os significados: «puerto (de mar o de montaña)». Igualmente Barreiro (1985) regista esta aceção e diversos exemplos: «puerto, paso entre montañas». 
Estando aly el rey, chegaronlhe novas da rainha dona Biringuela, sua madre, como se viinha veer con elle e que partira ja de Toledo. E el, logo que o soube, partiosse de Cordova e levou consigo sua molher e passou o porto e chegou a hũu logar que avya nome Poçollo e agora lhe chaman Villa Real, ca o iffante dõ Affonso, seu filho, fez aly depois hũa muy nobre villa (ibidem, p. 436).

Segundo Corominas, esta aceção da palavra é, nas línguas romances do ocidente, exclusiva do castelhano ${ }^{41}$, o que não se confirma, como acima se verifica, onde tem um sentido mais próximo de «passagem, entrada, porta», que os dicionários de português ainda registam considerando-o diacronismo (Dicionário Houaiss da língua portuguesa, 2001).

A polissemia da palavra justificará de resto que, frequentemente, a referência a portos marítimos se faça, preferindo uma designação mais completa: «porto de mar».

Esta acecção do termo «porto» poderia ter dado origem a uma utilização para designar passagens estreitas em espaço urbano, como o que é referido na cantiga de Joam Soares Coelho. Ou seja: vielas, becos, lugares propícios a encontros secretos. Não encontrei, no entanto, nenhuma ocorrência da palavra com esta aceção associada a espaço urbano.

O sentido mais frequente de porto marítimo (fluvial ou lacustre) deu, porém, origem a uma extensão de sentido que, essa sim, encontrei associada, se não a espaço urbano pelo menos a espaço edificado. Um porto é um lugar importante de abrigo, de proteção e mesmo de salvação, pelo que a metáfora é bastante óbvia. Encontramo-la na cantiga de Santa Maria 6: «Pois diss': "Ai, Santa Maria, / Sennor, tu que es porto / u ar[r]iban os coytados" $\gg^{42}$.

Mas na cantiga de escárnio de Pero da Ponte Marinha Lopez, oy mays a seu grado, o porto de abrigo de que se fala é uma casa; precisamente a casa de um nobre (Don Lopo) que parece ter em curso a formação de um exército («mil cavaleyros»). Diz o sujeito da cantiga de Pero da Ponte que «se pobr'ou coytado passar, / per aquel porto, save-1(o) (a) albergar / e de mays darlh'[a] albergu' endoado» (JUAREZ BLANQUER 1988: 223).

Do mesmo modo, creio que os «portos» de que Coelho fala na cantiga em análise são apoios (político-militares) que «Don Estevan» não conseguiu ou

«en el sentido de 'collado de la sierra'y ' territorio serrano', que es particular del castellano» (COROMINAS e PASCUAL 2006-2007, vol. 4, p. 682); «En quanto a porto en este sentido no tengo noticia de que exista en portugués, y en gallego lo dan sólo Carré y Eladio Rdz. (dato sin valor): está una vez en los MirSgo. 124.19, pero traduciendo el episodio carlovingio de Roncesvalles»(ibidem, p. 683).

42 Barreiro (1985) regista a expressão figurada «porto de soude» atribuindo-lhe o sentido «lugar en donde se encuentra refugio y defensa»: «señor Santiago [...] solta as cadeas das nosas maldades et tragenos a porto de soude. Et amerçeate agora de nos ẽno p[e]rigo da morte». 
perdeu. A localização bastante precisa do espaço será suficiente indicação sobre junto de quem falhou «Don Estevan» na angariação de apoio ou sobre junto de quem caiu em desgraça.

O sentido do verbo «ver» volta, neste caso, a constituir um desafio. O sujeito afirma que o comportamento de «Don Estevan» é próprio de quem não vê nada, não de quem vê mal, embora haja quem esteja convencido de que «Don Estevan» apenas vê mal. Esta forma de apresentar a questão afasta só por si o sentido literal do verbo «ver», uma vez que o sentido literal não é discutível. Se «Don Estevan» fosse cego, no sentido de lhe faltar o sentido da visão, como diz o sujeito da cantiga, não haveria quem pensasse que ele via mal e quem defendesse com veemência, como o sujeito da cantiga, que ele não via, uma vez que a incapacidade total para ver não é disfarçável. É, portanto, precisamente a abordagem escolhida por Coelho ao assunto que aponta para um significado não literal do sentido de «ver».

Recuperando ambos os significados que o verbo «ver» assume nas cantigas estudadas, verificamos que apenas um se pode admitir neste caso. Na cantiga de Airas Peres Vuitorom, «ver» significa «receber benefício»; assim como na cantiga de Tenoiro, embora de forma mais subtil. Já na primeira cantiga de Joam Soares Coelho, «ver» significa compreender, percecionar uma situação social complexa, para além do que esta apresente de óbvio. Considerando o sentido determinado para o verbo «caer» (ser mal-sucedido ou cair em desgraça), assim como o contexto geral da cantiga, será seguro afastarmos o sentido apurado para o verbo «ver» nos escárnios de Vuitorom e Tenoiro (receber benefício). Já o sentido que Coelho usou na sátira anteriormente estudada - compreender, percecionar uma situação complexa nos seus aspetos menos óbvios - adequa-se ao contexto. Ao contrário dos outros que consideram ter «Don Estevan» uma perceção reduzida da situação, o sujeito da cantiga manifesta-se convencido de ser nula a perceção de que esta figura é capaz. Para o sujeito da sátira em análise, «Don Estevan» age completamente inconsciente («non vee nemigalha»).

Prosseguindo com o esclarecimento do vocabulário que dele possa carecer, importa dedicar alguma atenção ao vocábulo «tojal», que não ocorre em nenhuma outra cantiga da Lírica Galego-Portuguesa, incluindo as cantigas de Santa Maria. Corominas indica a ocorrência nas Inquirições de $1258^{43}$. O tojo é uma planta agreste, coberta de espinhos, que deu origem a uma expressão bastante significativa da pobreza associada: «possuir dois tojais» significa ter poucos meios ou recursos diminutos, e está atestada desde 1521-1558 (Dicionário Houaiss da língua portuguesa, 2001). 
A acusação de não saber sair de um tojal poderá significar a incapacidade para sair de uma situação espinhosa, exigente de uma capacidade de perceção que «Don Estevan» não tem («non vee mal / quen vee derredo quanto deante») e de uma habilidade ( «non sabia sair») de que não dispõe. No entanto, o topónimo a que o tojal referido aparece associado poderá indicar que teria, além de um sentido metafórico, também um sentido literal.

Amarante é envolvida na experiência anterior em que o sujeito da cantiga baseia as suas conclusões sobre a capacidade de entendimento de $\ll$ Don Estevan». Diz ele que, junto a Amarante, mas não em Amarante, «fora da via», «num tojal», viu «Don Estevan» em apuros por não saber sair do tal «tojal». Ora, no período em que estas cantigas foram compostas podia ocorrer, junto a Amarante, num ermo precisamente, de acordo com os relatos, um empreendimento que daria que falar. Se assim aconteceu, tal fama poderia embaraçar o arcebispado de Braga.

A memória que resta dos acontecimentos é uma lenda, mas os hagiólogos reconhecem que se terá desenvolvido a partir de factos reais. Os reflexos que talvez encontremos na discussão trovadoresca em estudo reforça esta convicção.

Segundo C. Sobral, que dedicou à Vida de São Gonçalo de Amarante um estudo com vista ao levantamento de hipóteses de datação e identificação de autoria (1997), o relato mais antigo dos acontecimentos terá sido um Texto de Amarante, baseado ele próprio em textos escritos e orais provenientes de Amarante. Com base neste perdido Texto de Amarante terá sido composto o texto da Vida que se encontra no Flos Sanctorum, impresso em Lisboa, em 1513; mas também um ofício composto por André de Resende ${ }^{44}$, contendo igualmente a Vida de São Gonçalo de Amarante, entretanto perdido, não sem antes dar origem a duas versões que se conservam: uma de frei Diogo do Rosário e outra de frei Estêvão Sampaio. A versão mais antiga dos acontecimentos é a que se encontra, portanto, no Flos Santorum de 1513. Mas os aspetos dos relatos que poderão interessar-nos para a interpretação desta discussão trovadoresca encontram-se em todas as versões e consideram-se marcos biográficos de frei Gonçalo de Amarante, pelo menos para aqueles que não duvidam da existência histórica do indivíduo. De resto, são aspetos que nada têm de sobrenatural; mostrando, pelo contrário, uma situação política e um esforço retórico que podem ter constituído o ponto de partida para uma posterior transformação com introdução de elementos sobrenaturais e outros.

44 Lembremo-nos de que, entre os papéis de André de Resende, andaram cópias de cantigas trovadorescas, que deram origem a um dos testemunhos da Lírica Galego-Portuguesa, onde se encontra a tenção entre Afonso Sanches e Vasco Marins de Resende (P) (GonçALVES 1993). 
São estes aspetos da criação de Gonçalo pelo arcebispo de Braga, que a Vida não identifica, mas frei Luís de Sousa pensa ter sido Estêvão Soares (sousA 1977: 163-164), a atribuição por este a Gonçalo da igreja de São Paio de Riba de Vizela ${ }^{45}$ e o título de abade. Querendo partir em peregrinação, o santo deixou a igreja e todos os haveres a um seu sobrinho, que educara. Durante a demorada ausência de Gonçalo, o sobrinho apresenta documentação e testemunhas falsas ao arcebispo de Braga, para provar que o tio teria morrido e obter o reconhecimento de uma herança indevida: precisamente a igreja de São Paio de Riba de Vizela que o tio lhe confiara. O texto da Vida esforça-se, neste passo, por inocentar o Arcebispo, identificado por frei Luís de Sousa já com Silvestre Godinho, sublinhando o esforço feito pelo sobrinho de Gonçalo no engano, e repetindo-o. Cito o passo pela edição de C. Sobral:

Assi, pollo contrairo, o coraçõ de seu sobrinho per spiritu diabolico enganado, cõ falsas e sorreticias letras cõfeitas se foy ao arcebispo, enformãdo-o da morte de seu tio, cõ falsas testimunhas cõvocadas pedindo-lhe que o cõfirmasse em aquella ygreja vagante. E o arcebispo, enganado per falsa cõfissam das testimunhas e nõ verdadeiro testimunho das ditas letras, deu cõsentimento aa sua petiçõ e por abade o cõfirmou (2000: 608).

Parece importante para quem escreve estas linhas que não restem dúvidas sobre não ter havido conivência entre o Arcebispo e o sobrinho, ou seja, que fique bem assente a inocência do Arcebispo e a culpa do sobrinho. Ora, é precisamente tamanho afinco que faz pensar na possibilidade de tal situação ter constituído embaraço para o arcebispado de Braga, quando o alarido em torno de Gonçalo a torna conhecida. Note-se não haver nenhuma menção, na Vida, a qualquer tentativa de reparação pelo arcebispado da injustiça, apenas tornada conhecida graças aos feitos posteriores de Gonçalo, que sobre ele chamaram a atenção. De facto, 14 anos passados após a partida, Gonçalo regressa e, sendo escorraçado pelo sobrinho, desce o rio Tâmega acabando por instalar-se numa ermida junto a Amarante, onde constrói ou restaura uma ponte, recolhendo donativos e contando com dádivas em trabalho de quem não pudesse fazer donativos. O empreendimento, julgado impossível mesmo por aqueles que para ele contribuem, vai decorrendo ao mesmo tempo que atrai a atenção para o caso, dando então azo a relatos fabulosos sobre os odores de santidade que emanam dos modos como Gonçalo ultrapassa dificuldades diversas.

\footnotetext{
45 É na freguesia de São Paio de Riba de Vizela que, em 1228, o casal Fernão Anes Cheira Riba de Vizela (rico-homem da corte de Sancho II) e Maria Mendes da Silva vendem uma propriedade que ali tinham. (PIZARRO 1997, vol. 1, p. 542)
} 
A datação dos acontecimentos é naturalmente incerta, até porque a lenda não oferece nenhum elemento cronológico, e de Gonçalo resta apenas um documento da Colegiada de Guimarães datado de 1279. Considera-se, no entanto, que o início da edificação da ponte terá acontecido entre 1247 e 1250 (MACHADO 1979: 22), ou seja, logo a seguir à tomada do governo do reino por Afonso III. O que coincide com a datação do conjunto satírico em análise.

A possível alusão a São Gonçalo de Amarante, por Joam Soares Coelho, poderá ter aberto um filão criativo que será explorado, não por este trovador, mas por Tenoiro e Vuitorom nas cantigas que de seguida analisarei. É importante sublinhar a coincidência entre o caso de Gonçalo e do sobrinho, por um lado, e o caso de Joam Viegas e Sancho II, por outro, já que, precisamente esta coincidência tornava a alusão aliciante. Na verdade, tal como Gonçalo beneficiara o sobrinho, confiando-lhe a sua igreja, os seus pobres e os seus bens, sendo depois traído pelo sobrinho que tudo lhe rouba, com a conivência do arcebispado de Braga; assim também Joam Viegas de Portocarreiro, provavelmente beneficiado por Sancho II na eleição para arcebispo de Braga, opta por trair o Rei que o beneficiara, no momento em que se torna testemunha do Juramento de Paris e executante da bula papal de deposição de Sancho II. E se quisermos continuar neste jogo de espelhos, que poderá justificar a declaração segundo a qual «Don Estevan» nada vê; do mesmo modo, Joam Viegas favorece Afonso III em tudo o que pode e, no entanto, Afonso III nada cumpre do que promete, para, com a ajuda dele e restante clero, conseguir chegar ao poder. Eis o que «Don Estevan» não vê ou não compreende, porque a capacidade de entendimento para tanto não lhe chega: a menos que se seja santo, como frei Gonçalo de Amarante, a traição com traição se paga, por isso, «Don Estevan», mesmo que seja bem recebido (caeu mui ben), é mal recebido (cai mal) e, sobretudo, cai em desgraça, no insucesso.

A referência a Amarante era ainda, para Joam Soares Coelho, uma cartada no prestígio de Egas Moniz, seu antepassado mais ilustre, uma vez que a formação de Amarante se deve a terras de duas bisnetas de Egas Moniz (ibidem, p. 46). Numa época em que os elementos da pequena nobreza procuravam aproveitar as oportunidades que poderiam abrir-se na nova corte de Afonso III e usar todos os argumentos que pudessem, a questão talvez não fosse menor.

$\mathrm{O}$ advérbio «derredo» (《quen vee derredo») ocorre numa cantiga de Airas Peres Vuitorom (Don Fernando, vejo-vos andar ledo ${ }^{46}$ ) e noutra cantiga de Fernando Esquio (Disse un infante ante sa companha ${ }^{47}$ ), ambas de escárnio. Nos dois casos, o vocábulo é usado no contexto de oposições, como acontece na can-

\footnotetext{
46 Lapa (1970a: 136).

47 Ibidem, p. 237.
} 
tiga de Joam Soares Coelho: «punhade d'ir adeant'ũa vez, / ca, atra aqui, fostes sempr'a derredo» (Airas Peres Vuitorom); «e nom and triste nem ande ledo / nem vaa deante, nem a derredo» (Fernand'Esquio). Este facto não deixa margem para dúvidas sobre o sentido literal do advérbio ${ }^{48}$.

Não convirá começar pelo princípio a interpretação geral da cantiga de Joam Soares Coelho, uma vez que o sujeito expressa ali uma opinião fundamentada num passado referido na última estrofe. Segundo se afirma na segunda e terceira estrofes, é convicção geral que «Don Estevan» vê mal. Num jogo de expetativas que terá provocado espanto e riso, o sujeito discorda primeiro desta convicção geral («digu'eu que mente ca diz mui gran falha / e mostrar-lh'-ei que non disse ren / nen é recado que nulha ren valha»), tendo provavelmente levado o público a crer que se seguiria a defesa do contrário desta afirmação, ou seja, a defesa de que «Don Estevan» veria muito bem. Defraudando esta expetativa, com efeito cómico, o sujeito logo afirma a certeza de que «Don Estevan» não vê nada. Ou seja, Coelho primeiro provoca no público a expetativa de que vai defender a perfeita capacidade de ver de «Don Estevan», para depois defender que, mais do que ver mal, «Don Estevan» não vê nada. O efeito cómico terá sido obtido na segunda estrofe, com a novidade. Na terceira estrofe, onde a novidade já não existe, $\mathrm{o}$ autor repete o jogo, mas fundamenta agora a convicção exposta, e nela adensa-se a sátira de fundo ao visado ( «sei que lho non diria / ca vee mal, se migo falass'ante / ou se o viss'andar fora da via / como o eu vi en, junt'a Amarante / que non sabia sair dun tojal»).

A diferença de opiniões sobre o grau de invisualidade de «Don Estevan» é claro sinal de que tal defeito de visão não deve ser entendido como um defeito físico. Uma cegueira total não é discutível, nem é crível que uma pessoa com cegueira total se encontre sozinha no meio de um tojal sem dele saber sair. Sendo a cegueira discutível, ela será metafórica, ou seja, será uma forma de referir a capacidade de discernimento de «Don Estevan». Segundo a opinião geral, esta é reduzida; segundo o sujeito da cantiga em apreço, a capacidade de discernimento de «Don Estevan» é nula. Tal opinião é fundamentada numa experiência em que «Don Estevan» foi visto pelo sujeito. Assim como na cantiga de Coelho, anteriormente analisada, também aqui se contrapõe a incapacidade de visão, ou de entendimento, de «Don Estevan», à capacidade de visão e discernimento dos outros, neste caso do sujeito, que, a partir da observação feita, não só tira conclusões como argumenta contra posições (mesmo que falsamente) contrárias. Onde «Don Estevan» se apresenta destituído, o sujeito, neste caso, contrapõe capacidade de observação, elaboração e argumentação.

48 Marcenaro considera a oposição «deante / derredo» alusiva a relação homoerótica (2014: 69, 114, 116). Os exemplos dados não apontam para uma ligação exclusiva entre esta oposição e aquele sentido. 
O sujeito desta cantiga oferece-se, pois, como testemunha de uma situação na qual «Don Estevan», junto a Amarante, «fora da via», num «tojal» demonstrou incapacidade de entendimento, para se desembaraçar de uma situação espinhosa («non sabia sair dun tojal»). A referência a Amarante e a descrição da situação poderão constituir uma alusão ao caso, eventualmente comentado, com embaraço para o arcebispado de Braga, do beato frei Gonçalo de Amarante e da construção de uma ponte por este empreendida, nos arredores de Amarante. O caso seria duplamente embaraçoso para Joam Viegas de Portocarreiro. Em primeiro lugar, porque um arcebispo de Braga, talvez o seu antecessor e amo, Silvestre Godinho, teria confirmado a usurpação da igreja e bens de Gonçalo por um seu sobrinho, sem que esta usurpação tivesse nunca sido corrigida, após o reaparecimento do beato. Depois porque, tal como este sobrinho traíra quem o beneficiara e nele confiara, também Joam Viegas fizera o mesmo a Sancho II.

Se considerarmos haver, na última estrofe da cantiga, uma alusão à presença de frei Gonçalo junto a Amarante e à construção ou restauro da ponte, voltamos a encontrar indícios de que a composição desta cantiga terá ocorrido já depois da morte de Sancho II. Correriam tempos em que a governação de Afonso III começaria a consolidar-se, e em que o clero descobriria o incumprimento do Rei do Juramento de Paris. A construção da ponte em Amarante está datada de anos entre 1247 e 1250 (MACHADO 1979: 22), mas, dado que foram necessários donativos e braços, e provavelmente também a possibilidade de trânsito seguro, que antes de 1245 não existia, é pouco provável que tenha ocorrido antes do fim do conflito, ou seja, antes da retirada de Sancho II ou mesmo da sua morte.

Os dois últimos versos da terceira estrofe («por én vos digo que non vee mal / quen vee derredo quanto deante»), paralelísticos dos dois últimos versos da segunda estrofe ( $\ll \mathrm{ca}$ non pode per nulha ren veer / mal ome que non vee nemigalha»), repetem o desfecho que já estes encerram: que «Don Estevan» não pode ver mal, porque na verdade nada vê. Esta leitura dos dois últimos versos impõe uma emenda ao último verso da composição, supondo que o copista de $\mathrm{v}$ fez uma simples troca de um «o» por um «e», ou já um copista do antecedente por ele copiado. De facto, o verbo «ser» («quant'é»), no último verso da cantiga, permitiria entender dispor «Don Estevan» da visão que toda a cantiga se ocupa de negar. «non vee mal / quen vee derredo quant'é deante» significaria não ver mal aquele que vê atrás aquilo que se encontra à frente. Além da incoerência relativamente ao que é afirmado no resto da cantiga, é também uma afirmação sem aparente sentido. Procedendo à emenda proposta, o verso alinha-se com o que é afirmado nos últimos versos da segunda estrofe ( «ca non pode per nulha ren veer / mal ome que non vee nemigalha») e é coerente com o que é afirmado ao longo da cantiga («no vee mal / quen vee derredo quanto deante»). 
Torna-se também totalmente compreensível: não vê mal aquele que vê à frente o mesmo que vê atrás, ou seja, aquele que nada vê, nada entende.

$\mathrm{O}$ testemunho do sujeito em que este fundamenta uma opinião sobre as capacidades de «Don Estevan» está associado a um tempo passado («como o eu vi») e a um espaço identificado («junt'a Amarante»). No seu conjunto, encerra a condenação de decisões tomadas no presente. Tais decisões estão subjacentes à «partiçon» de que se fala na primeira estrofe, a qual se associa, ao contrário das duas seguintes, a um tempo presente («fez sa partiçon», «caeu»). Como aconteceu no passado em que «Don Estevan» demonstrava incapacidade de entendimento, além de inabilidade para se desenvencilhar de situações espinhosas, também as escolhas subjacentes à «partiçon» feita com os irmãos (ou primos), segundo o sujeito, demonstra, para a maior parte das pessoas, que ele tem reduzida capacidade de perceção das situações; para ele próprio, demonstra que não tem nenhuma.

Neste contexto, o verbo «cair» é usado, como na cantiga anteriormente analisada, para exprimir sentidos opostos: ser bem recebido e ser mal-sucedido ou cair em desgraça. Devido à perda de um verso, não sabemos onde foi «Don Estevan» bem recebido, mas sabemos que foi mal recebido em Santarém, espaço urbano que foi rapidamente dominado pelo Conde; e que foi mal-sucedido ou caiu em desgraça em Coimbra, nos três «portos» onde não conseguiu «abrigo». Esta será uma forma de dizer que «Don Estevan», depois das escolhas que fez, se terá perdido tanto em Santarém, junto do rei Afonso III, quanto em Coimbra, a cidade de Sancho II. Não admira que, depois de uma primeira estrofe em que «Don Estevan» é mostrado a perder em toda a linha, mesmo tendo sido bem recebido por um dos partidos; a partir da segunda estrofe, a cantiga se ocupe de concluir e demonstrar a falta de discernimento de quem fez más opções políticas e se saiu mal por isso. 


\title{
Roi Queimado
}

1 Don Estevan, en grand'entençon ${ }^{49}$ foi ja or'aqui por vosso preito oi dizer por vós que a feito sodes cego, mais dix' eu que mui ben

5 oides cada que vos cham' alguen vedes como tiv'eu vossa razon.

E muito vos oi eu oje mal sén dizer por vós: que a feito [non] sodes cego, e dix' eu log' enton

10 esto que sei que vos a vós aven que nunca vos ome diz nulha ren que non ouçades, se Deus mi perdon.

\author{
Oi dizer por vós que á sazon \\ que veedes: quando pois me deito \\ 15 e dormesco e dormio ben a feito \\ que assi veedes vó-lo a son. \\ E assanhei-m'eu e dixi por en: \\ confonda Deus quen cego chama quen
}

assi ouve como vó-lo «sarmon».

49 B1386/V995 Aparato crítico - 1. estauam v; 6. tuieu uossa B; 9. lognenton B; 11. muicau9 B; 14. vedes quanto B uedes quanto V; 18. tego v. - A presente edição afasta-se significativamnte das edições anteriores, aproximando-se delas, sempre que estas se mantêm próximas das lições dos manuscritos. No verso 1, onde R. Lapa (1970a: 612) emendou a lição de ambos os manuscritos «engrande» para «ũa grande», concordo com CMGP e Lorenzo Gradín e Marcenaro (2010: 248) que recuperam a lição dos cancioneiros, entendendo o subsequente «foi» como primeira pessoa do verbo «ser». No verso 7 e 8 , a presente edição afasta-se de todas as precedentes, mantendo integralmente a lição dos manuscritos (в: «E muytoug oy eu oie mal sen / Dizer por uos que a feyto»; v: «E muytoug oyeu oie mal sen / dizer $\mathrm{p}^{\mathrm{e}}$ uos qa feyto»), à qual apenas se acrescenta uma conjetura, diferente das conjeturas feitas nas edições anteriores. Ao verso 8 falta certamente uma palavra, uma vez que apresenta uma medida muito inferior à dos restantes ( 7 ' vs. 9 a 10'). A edição de R. Lapa destes dois versos - «E muitos oí eu oj’e[n] mal son / dizer por vós [atal]: que, a feito,» - foi no essencial mantida em CMGP, e parcialmente revista em Lorenzo Gradín e Marcenaro - «E muitos oí eu oje mal son / dizer por vós [aqui]: que, a feito,». Ambas as integrações propostas por R. Lapa e em Lorenzo Gradín e Marcenaro são feitas no mesmo lugar do verso, mas em nenhuma das edições se encontram explicações sobre as razões da escolha deste lugar. Explico a conjetura feita na presente edição, bem como a escolha do local do verso onde foi integrada, ao longo da interpretação do texto. Quanto às restantes emendas feitas nos versos 7 e 8, R. Lapa não se detém a explicá-las, mas em Lorenzo Gradín e Marcenaro (2010: 252) consideram-se «due lezioni errate», no verso 7: «l'inserzione del pronome atono vos dopo l'indefinito muito, spiegabile come banale errore per addizione causato probabilmente della vicinanza del 
Não é possível avançar para a interpretação deste texto, sem antes revermos a edição de R. Lapa (1970a: 612). Os editores que posteriormente voltaram a ocupar-se do texto - CMGP, por um lado, e Lorenzo Gradín e S. Marcenaro (2010: 248-255), por outro - fizeram já pontuais revisões. Há, no entanto, um entendimento da forma do texto que a todos aproxima e que a todos conduz a um afastamento, maior ou menor, das cópias transmitidas pelos cancioneiros. Com este entendimento essencial, e respetivas consequências, não estou de acordo. As cópias transmitidas pelos manuscritos oferecem, tanto do ponto de vista formal quanto do ponto de vista do conteúdo, um sentido alcançável, quer quando considerada a cantiga individualmente, quer quando considerada no conjunto das que foram dedicadas a «Don Estevan». Pelo contrário, tal como editada por R. Lapa ou pelos editores subsequentes, a cantiga resiste à interpretação.

Transmitido por dois testemunhos (в е v), o texto não apresenta ali diferenças significativas. Ambas as cópias se mostram também bastante «limpas»e

medesimo elemento nel verso seguente» (ibidem, p. 253) e «sen in luogo di son, emenda necessaria ad assicurare la regolarità della rima». $\mathrm{O}$ verso 7 , tal como se apresenta nos manuscritos, parece apresentar excesso de uma sílaba. Poderímos eliminar o $\ll \mathrm{E} \gg$ inicial, supondo um acidente de transmissão na leitura de um «M» maiúsculo inicial muito decorado, que tivesse confundido um copista demasiado afastado, no tempo ou no espaço, para o entender. Em Lorenzo Gradín e Marcenaro (2010: 248) é regularizado o verso com a eliminação do pronome «vos», que se considera «un elemento non necessario nella semantica del verso» (2010: 253). Pelo contrário, considero o pronome essencial na interpretação do texto. No verso 9 , R. Lapa emenda a lição dos manuscritos «loguenton» $($ в); «loguẽton» $(\mathrm{v})$ : «Erro fàcilmente corrigível para a expressão a eito, exigida pela rima e significando: “direitamente, sem vacilar, imediatamente”. A série aparece nas "Cantigas de Santa Maria”, n. ${ }^{\circ}$ 323, est. 2, com o sentido que tem actualmente. Aqui, porém, deve-se-lhe atribuir um valor algo diferente, dentro da mesma esfera semântica» (LAPA 1970a: 612). Em P. Lorenzo Gradín e Simone Marcenaro (2010: 248), a emenda e o entendimento de R. Lapa são acolhidos: «BV sono concordi nel riportare una lezione chiaramente erronea (logu enton), per motivi di schema rimico».É acrescentada uma explicação insuficiente para tal deturpação: «L'errore si produsse nell'antigrafo dei due codici colocciani, per probabile confusione con la rima in - on del v. $7 \gg$ (ibidem, p. 253). Em CMGP, a proposta de R. Lapa é também acolhida, em nota à cantiga, considerando «entom, certamente um erro», embora não se explique porquê. Braga (1878: 187) e Elza Machado e J. Machado (1949-1964, vol. 7, p. 123) mantêm a edição mais próxima dos manuscritos, embora também não expliquem o entendimento do texto. No verso 14, R. Lapa fez uma integração por razões sintáticas - «que vedes [já] quanto, pois me deito» - com que concordam os editores subsequentes. A presente edição afasta-se desta solução, embora as mesmas razões sintáticas tenham levado a uma simples emenda de «t» por «d», supondo um erro de cópia fácil e frequente. Apesar de tanto a forma «vedes» como a forma «veedes» serem possíveis, como demonstra esta mesma cantiga, creio haver indicação no metro de que, no verso 14, terá sido omitida uma de duas letras iguais, erro frequente em manuscritos. O verso 16 é eliminado por R. Lapa (1970a: 612) com a seguinte justificação: «os dois mss. trazem uma interpolação desajeitada [... ] O escriba não percebendo o sentido dos versos anteriores, procurou esclarecê-lo num outro verso, de que resultou uma trapalhada ininteligível». Em Lorenzo Gradín e Marcenaro (2010: 53-54) considera-se que terá sido uma glosa marginal feita por um leitor e copiada por engano no interior da estrofe. O metro e a rima do verso, porém, não apoiam esta hipótese. Concordo com a recuperação do verso proposta em CMGP, embora não concorde nem com a emenda que lhe é feita («que assi veedes vólo artom»), nem com a resultante configuração estrófica da cantiga. A presente edição afasta-se de todas as outras, considerando a existência de uma finda e de um esquema métrico-rimático diferente do suposto até agora, opção que é explicada na interpretação do texto. 
feitas em circunstâncias codicológicas pouco propícias a acidentes; isto é, ambas foram feitas na mesma página dos respetivos cancioneiros, e não se verificam rasuras, nem hesitações nem nenhum outro fenómeno do género. Tudo isto significa que o antecedente copiado para ambos os cancioneiros deveria ser de fácil leitura e interpretação, não oferecendo provavelmente aos copistas dificuldades à operação de cópia. O mesmo é dizer que quaisquer deturpações do texto que tenham acontecido durante a história da transmissão terão mais provavelmente acontecido antes do antecedente das cópias que o trouxeram até nós. Ora, quanto mais para trás andamos, mais nos aproximamos dos participantes ativos nesta lírica (trovadores, jograis, público); mais perto ficamos de tocar na memória viva dos criadores. Especialmente, no caso desta lírica que, segundo julgamos saber, teve uma transmissão escrita limitada. Ou seja, quanto mais andamos para trás, mais improváveis são os acidentes de cópia que envolvem certo tipo de danos textuais, como integrações de versos inteiros ou a substituição de duas ou três palavras totalmente diferentes. Foi, no entanto, precisamente o que R. Lapa supôs ter acontecido durante a cópia desta cantiga.

A primeira estrofe apresenta um esquema rimático - abbcca - que, de acordo com os manuscritos, não se repete nas duas estrofes seguintes (abcaac; abbacca). Mais: a última estrofe tem, nos manuscritos, mais um verso do que as estrofes anteriores. Para conseguir que as duas últimas estrofes apresentassem o mesmo esquema rimático da primeira estrofe, $R$. Lapa supôs então que, durante a transmissão do texto, um copista tivesse introduzido um verso espúrio na última estrofe (в: «Que assy ueedes uolo açon»; V: «q̃assy ueedes uolo açon») $)^{50}$ e que, na segunda, as palavras «a eito» tivessem sido substituídas, por razões inexplicadas, por «enton». Supõe ainda que o verso «E muito vos oi eu oje mal sén» $($ в/v) tivesse resultado da deturpação da lição «E muito oí eu oj’ e[n] mal son». Em consequência destas suposições, R. Lapa elimina, na edição crítica, o verso da terceira estrofe, que considera espúrio, e recupera as lições que considera terem

«Depois deste verso os dois mss. trazem uma interpolação desajeitada: que assy ueedes volo açon. O escriba não percebendo o sentido dos versos anteriores, procurou esclarecê-lo num outro verso, de que resultou uma trapalhada ininteligível» (LAPA 1970a: 612). Em CMGP o verso eliminado por Lapa é emendado: «açon» (BV) é corrigido para «artom», o que supõe um erro do copista de explicação relativamente aceitável. É no entendimento do texto - «arteiro, ou seja, astuto, manhoso, aqui no duplo sentido de malfeitor (D. Estêvão faria a ronda nocturna na caça aos malfeitores), mas também de homossexual» - que creio falhar a emenda, além de ser desnecessária. Em P. Lorenzo Gradín e S. Marcenaro (2010: 54), onde o verso é considerado interpolação tardia e portanto eliminado da edição, considera-se igualmente necessário corrigir a lição «açon» (BV) para «ançon», com o sentido de objeto de dimensões muito pequenas. A explicação do erro do copista seria igualmente aceitável, mas desta emenda não resulta um verso compreensível, além de ser desnecessária. Braga (1878: 187: «que assy veedes vol-o a son'; ) e Elza Machado e J. Machado (1949-1964, vol. 7, p. 123: «Que assy ueedes uo lo açon.») são conservadores na edição, como é próprio da natureza das edições que fizeram, mas não sabemos como entenderam o texto. 
sido deturpadas. Por outras palavras, emendando, R. Lapa força as duas últimas estrofes à forma da primeira estrofe: abbcca.

Em CMGP aceitam-se as intervenções na segunda estrofe, que lhe dão a mesma forma da primeira. Recupera-se, no entanto, o verso eliminado por R. Lapa na terceira estrofe (abbacca), supondo, em nota, a perda de um verso nas estrofes I e II (abbcca), sem explicar, porém, o modo como a sintaxe ali acolheria tais versos, supostamente perdidos sem deixarem vestígios nos manuscritos. Os editores de Roi Queimado aceitam as emendas de R. Lapa que forçam as estrofes II e III a assumir a mesma forma da estrofe I, revendo apenas leituras que não questionam este princípio. Como confessado por R. Lapa e por todos os editores subsequentes, a cantiga permaneceu até hoje... difícil de compreender.

Voltemos aos manuscritos. Se considerarmos o último verso da última estrofe uma finda, que acidentalmente tenha sido escrita sem maiúscula inicial, confundindo o copista, teremos todas as estrofes com o mesmo número de versos, o que permitiria a repetição da música durante a execução musical. A primeira e a terceira estrofes apresentam um esquema rimático coincidente na primeira parte e variante na segunda parte: abb|cca (I); abb|acc (III). Está longe de ser caso único na Lírica Galego-Portuguesa. Bastará consultar o Repertorio metrico della lirica galego-portoghese (TAVANI 1967b), para encontrarmos inúmeros exemplos de cantigas cujas estrofes estão divididas em dois grupos com estas caraterísticas: os respetivos esquemas rimáticos têm uma primeira parte coincidente e uma segunda parte variante. Apresento apenas alguns exemplos: Roi Martins do Casal (145,7) - ab|ba (I, III); ab|ab (II) - Juião Bolseiro $(85,19)$ - aab|ab (I); aab|cb (II, III) - Diego Pezelho (28,1) $\mathrm{aab}|\mathrm{ab}(\mathrm{I}) ; \mathrm{aab}| \mathrm{cb}$ (II, IV).

De acordo com o esquema rimático da primeira e terceira estrofes $\mathrm{abb} \mid \mathrm{cca}$ (I); abb|acc (III) - esperar-se-ia o mesmo esquema rimático nos três primeiros versos $(a b b)$ da segunda estrofe, o que não ocorre $(a b c)$. Dois factos indicam que uma palavra se perdeu no final do terceiro verso, porém. Numa cantiga em que o metro oscila entre as 9 e as 11 sílabas, este é o único verso com sete sílabas (contando apenas até à última sílaba tónica). Por outro lado, a sequência rimática abc, nesta cantiga, não faz sentido. Reconhecendo o primeiro facto, todos os editores propuseram integrações no interior do segundo verso da segunda estrofe. Se supusermos, no entanto, a perda de uma palavra no final do verso; se conjeturarmos que a palavra perdida terminava em «-on», teremos reencontrado o mesmo esquema rimático dos três primeiros versos das estrofes I e III: abb. Ou seja, também na segunda estrofe, teremos um esquema rimático coincidente, na primeira parte, e variante na segunda: abb $|c c a(I) ; a b b| a a b(I I) ; a b b \mid a c c(I I I)$. Na verdade, um padrão de repetição e variação muito interessante. 
O número de composições que, de acordo com o Repertorio metrico della lirica galego-portoghese, apresentam variações em todas as estrofes é bastante mais reduzido, mas este não é caso único. Veja-se a cantiga Deus, como se foron perder e matar, de Joam Garcia de Guilhade (70, 14): abab|aa (I) abab|bb (II) abab|cc (III).

Se considerarmos, portanto, três estrofes com três esquemas rimáticos parcialmente coincidentes e parcialmente variantes, as principais emendas de R. Lapa deixam de ter jutificação: na segunda estrofe, onde «mal son» veio substituir a lição do manuscrito «mal sén»; onde «log’a eito» veio substituir a lição dos manuscritos «logu' enton»e, claro, na terceira estrofe, onde o verso «que assi veedes vó-lo a son» foi eliminado. Em todos estes lugares, os manuscritos oferecem lições perfeitamente compreensíveis, que devemos recuperar. Deixaremos de encontrar nesta cantiga três estrofes uníssonas, como julgaram R. Lapa e os editores que o seguiram, uma vez que apenas a primeira e terceira estrofes repetem as rimas dos três primeiros versos, pela mesma ordem. Mas também neste aspeto esta cantiga não está sozinha no contexto da Lírica Galego-Portuguesa, além de ser assinalável o jogo rimático de Roi Queimado que, recorrendo sempre às mesmas rimas (on, en, eito), opta por dispô-las de forma variante. E não será talvez alheio a este jogo de repetição e variação o facto de, na segunda estrofe, se concentrar o principal esforço satírico da cantiga, como veremos.

Voltando ao segundo verso da segunda estrofe e respetivo contexto $(\ll \mathrm{E}$ muito vos oi eu oje mal sén / dizer por vós: que a feito ...on / sodes cego, e dix'eu log'enton»), repito que não há nos manuscritos nenhuma indicação de perturbação na cópia, o que nos tem de levar a supor que a perda já tinha ocorrido no antecedente ou mesmo antes dele. Mas, dependendo das circunstâncias de cópia, o final de um verso pode ser vulnerável à omissão, especialmente se a palavra for pequena, se os versos estiverem separados por sinais que possam interferir na memorização durante o processo de cópia (CORREIA 1997b); se houver mudança de fólio.

No contexto oferecido pelo próprio verso e pelos dois que o precedem e seguem, a palavra de uma sílaba terminada em «-on» que se apresenta como melhor candidata a vítima da omissão num acidente de cópia é o advérbio de negação «non». Não poderemos naturalmente descansar sobre a certeza, mas o grau de probabilidade é elevado, considerando sobretudo a sintaxe. O sentido da estrofe, assim como o sentido da cantiga muda consideravelmente, mas é perfeitamente inteligível, também graças ao que já foi apurado para as cantigas anteriormente estudadas.

Procedendo como anteriormente, começarei por esclarecer vocabulário e expressões desta cantiga, antes de avançar para a interpretação geral do texto. Há, logo na primeira estrofe, um «fio» semântico que une algum vocabulário, 
e mesmo algumas expressões, conduzindo-o para uma área específica com a qual o público terá imediatamente relacionado a cantiga para efeitos de interpretação. «en grand'entençon foi», «preito», «tiv'eu vossa razon» é terminologia de âmbito jurídico, embora não exclusivamente, pelo menos se usado isoladamente e, nalguns casos, em diferente contexto.

A palavra «entençon» refere também o género da Lírica Galego-Portuguesa «tenção», mas nunca o verbo «ser» é usado para introduzir a palavra com este sentido. Habitualmente, é o verbo «fazer» que indica o sentido literário do termo «entençon». O sentido jurídico ocorre na Lírica Galgo-Portuguesa em apenas mais uma composição, além da de Roi Queimado: na tenção entre Pai Gomes Charinho e um «Senhor» («por que an pavor / d'aver sobr'elo convosco entençon $\left.{ }^{51}\right)$. Mas podemos comprovar o sentido jurídico do termo precisamente em textos de caráter jurídico, como as Flores de dereyto:

Pero que a ley diz < que> poys as prouas foren publicadas que nenhũa das partes nõ pode aduzer outras prouas subre esta meesma razon. Pero se cartas ou estrumentos alguus ouuer que aiude a prouar sa entençon ben as pode mostrar ata que as razoes seyã encerradas. pera dar a sentença.

Se algua das partes mostrar cartas ou estrumentos alguus. en juyzo per que quer prouar sa entençõ. e a outra parte demandar o translado delhas. uos mandede lho dar en guysa que nõ den en el a era. nennos anos da encarnaçõ nen da endiciõ (FERREIRA 1989: 40).

Noutros textos da prosa medieval portuguesa, este sentido que se aproxima de «contenda, discussão ${ }^{52}$, mas também implica, ou pode implicar, o ponto de vista de alguém em tal contenda e discussão, ocorre igualmente, como se pode comprovar pelos exemplos que se seguem.

E, feitas e acabadas estas vodas, foy movida grande contenda antre os Franceses e os Castellãaos, dizendo os Franceses que a rainha dona Branca era a mayor filha del rey dom Afonso e que por esta razõ devya de herdar o reyno de Castella e que elles por a mayor das yrmãas a levarõ pera França. E con esta parte e entençon eram os cõdes de Lara. Mas algũus dos Castellãaos diziam que a rainha dona Biringuella era a mayor e sobr'esto ouverõ grãdes departimentos (CINTRA 1990: 364).

\footnotetext{
51 Lapa (1970a: 456).

52 R. Lapa já o indicava: «entençon = disputa» (ibidem, p. 612).
} 
Conhosco, padre, e confesso mui de boa mente que per tas bõas razões e per tas mui bõas declarações das outoridades que eu trouxi contra ti, e per outras muitas outoridades per que tu provasti a ta entençom, sõõ vençudo (SILVA 1971: 170)

Quanto a «preito ${ }^{53}$, é termo central no vocabulário jurídico, como pode comprovar-se em qualquer um dos textos jurídicos da época, por serem assim designados os casos em julgamento:

Quando quiserdes preguntar alguas das partes por saber a uerdade do pleyto. non consentades que o auogado falle con elle aa orelha nẽ sa[ya] a parte con elle fallar. Mays aquel a que fezerdes pregunta responda por sy meesmo. abertamente ca a ley por ende consentio. que os auogados razoassen. e demandassen por os donos do $<\mathrm{s}>$ preytos. porque o juiz podesse mays aiyna entender e saber a uerdade qua nõ que a uerdade s'ascondesse por elles (FERREIRA 1989: 9).

Embora ocorra na Lírica Galego-Portuguesa com outros significados, há também ocorrências com o sentido jurídico, como na cantiga de Estevam da Guarda, Meu dano fiz por tal iujz pedir: «Por tal iuiz nunca iá mais será / desenbargad'este preyto que ey» (PAGANI 1971: 106).

Tal como «entençon», também «razon» pode ter sentido literário, mas não quando ocupa o lugar de complemento direto do verbo «ter $\gg$ com o sentido de «suster», como acontece na primeira estrofe da cantiga de Roi Queimado: «vedes como tiv'eu vossa razon». Dado o contexto em que o vocabulário jurídico se acumula, não restam dúvidas sobre o significado que o vocábulo «razon» e o verbo «ter» têm no verso citado ${ }^{54}$. Veja-se emprego semelhante do verbo e substantivo nas Flores de dereyto:

E poys que ouuerdes pensado. e consellado como juyguedes < deuedes $>$ dar tal sentença segundo o que foy razuado ante uos ca o juiz nõ deue iuygar segundo sa conciencia, pero que o pleyto sabya, mays segundo que as razoes forẽ teudas ant'el (FERREIRA 1989: 42).

Para R. Lapa (1970a: 612), nesta cantiga, o significado de «por vosso preito» seria «a vosso respeito». Segundo nota em CMGP, o significado do termo «preito» seria «caso, assunto, questão» e em Lorenzo Gradín e Marcenaro (2010: 250) é-lhe atribuído significado semelhante: «affari».

54 Já R. Lapa (1970: 612) apontava neste sentido: «tiv'eu vossa razon = sustentei a vossa causa». Em Ferreiro (2016-, consult. 21 jun. 2021), no «Glossário», o significado atribuído a esta ocorrência do verbo «teer» é «considerar», o que não me parece acertado. 
Para um mais cabal esclarecimento do sentido jurídico de «razon», considerem-se mais alguns exemplos do termo usado neste contexto específico:

Porque muytas uezes s'enbargan os pleytos per parauras subeyas. non deuedes consentir mentre alguũ razoar ou dixer seu queyxome. que outro ome nonno enbargue nẽ que a elhe responda. ata que sa rrazõ ou sa querela ouuer acabada (FERREIRA 1989: 7).

E se por auentura errou a proua en seu testimõnho dizendo ou non dizendo pode $o$ enmendar ante que uaa fazer outras cousas ou que se parte do logar. Outrosy mandamos se dixer algua paraura escura ou douidosa pode o declarar enesta meesma razon. Mays des que aquella testimonha começar a dizer seu testymonho. nõ deuẽ fallar cũ nenhua das partes ata que o aya acabado (ibidem, p. 37).

E depoys que as prouas dadas assy forẽ publicas segundo o dereyto é, nenhua das partes nõ pode trager outras sobre aquesta razõ que forõ a estas aduzudas (ibidem, p. 40).

E se algunhas das partes non quiser uijr a qua1 quer destes plazos subredictos poys que foy aplazado sobre tal razon, uos deuedes ir adeante perlho pleyto segundo que manda o dereyto pero que a parte non seya presẽte (ibidem).

$\mathrm{Na}$ segunda estrofe, o sujeito dá conta de declarações feitas por «Don Estevan» acerca de si próprio, mas antes mesmo de o fazer qualifica-as como «dizer mal sén»: «vos oi eu oje mal sén / dizer por vós: que a feito [non] sodes cego».

A expressão «fazer mal sen» é frequente na Lírica Galego-Portuguesa e significa «agir erradamente». Vejam-se alguns exemplos: «E tenno que fazen mal sén / quantos d'amor coitados son / de querer sa morte» (FERREIRO 2016-); «Ora poss'eu con verdade dizer, / sennor fremosa, que faço mal-sen / en vus amar» (VASCONCELOS 1990a: 529); «Non se guardou de foder, e mal sén / fez el, que non poderia peor» (MARCENARO 2012: 367 ); «E pois ficastes probe, sen aver, / non veedes ca fezestes mal sen? 》 (LAPA 1970a: 465). «Dizer mal sén» terá o correspondente sentido de agir erradamente através de declarações.

A locução adverbial «a feito» é nuclear nesta cantiga e, tal como outras palavras ou conjuntos de palavras, é repetida em todas as estrofes: na primeira e na terceira, é repetida no terceiro verso em posição de rima; na segunda estrofe, ocorre no segundo verso antes da palavra em posição de rima. 
A locução não é frequente nem na Lírica Galego-Portuguesa nem na prosa medieval, não sendo fácil determinar o sentido exato que tem ${ }^{55}$. As ocorrências que se seguem apontam, no entanto, para que a locução adverbial «a feito» ou «afeito» transporte o sentido de totalidade por oposição a parcialidade; de completude, por oposição a incompletude. Este sentido distinguiria a locução adverbial «a feito» da locução adverbial «de feito», esta sim com o sentido de «realmente, de facto». A diferença de sentido justificaria, por outro lado, a coexistência de ambas as locuções. Vejamos algumas ocorrências:

E, quando os filhos de Noe partirõ per sortes a terra pera seer pobrada, aconteceu a Japhet em sua parte Europa, com os do seu linhagen. E partirõsse de Babillonya Japhet e seus filhos e veherõ pobrar Europa. E aqui dizem algũus que veheron cõ Japhet seus irmãaos, assi como dicto he onde falla da pobraçon d'Espanha, convem a saber, Sen e Cam, e que pobrarõ hi algũus logares; pero esto nõ faz a feito, por que Europa todavya de Japhet e do seu linhagẽ foi pobrada. E esta parte he pouco menos que a quarta parte do mundo. E esto, por que algũus partem o mũdo ẽ viI partes e dizem que ẽnas duas nõ mora nem hũu por / grande caentura e ennas outras duas outrossy por grande frio. E, das tres em que morã, esta he a menor parte. A Sen, o mayor filho de Noe, veeo per sorte Assya, cõ todo seu linhagem, e esta parte he assy como a meatade do mũdo. A Cam, o terceiro filho de Noe, veeo per sorte Africa, que he do mundo quasy a melhor parte (CINTRA 1984, vol. 3, p. 332 ).

«Pois cavalgade», disse el, «e iredes vos commigo; ca, si Deos me ajude, eu farei i iodo meu poder de vos levar i em salvo». «Ir com vosco», disse ella, «e tres cavalleiros veeram com migo e nom me poderom guardar, e guardar-m'-iades vos soo? Assi me seria eu sandia a feito de ir com vosco!» «Ai donzella», disse Gansonais, «ja mais nom dultedes, ca mais val seu corpo soo ca de taes XX cavalleiros que ha em esta terra» (PÍEL 1988: 163).

Outra tal vison com' esta / o Emperador dormindo

viu essa mẽesma noite / que o Papa; e sentindo

55 R. Lapa atribui-lhe o sentido «na realidade, efetivamente» (1970a: 612); «efectivamente, de facto» (1970b: 45), que já Vasconcelos (199ob: 38 ) lhe atribuíra («efectivamente, na verdade»), dando o exemplo da cantiga de Airas Moniz D’Asme, Pois mi non val d'eu muit'amar. Em CMGP concorda-se: «de facto». Lorenzo Gradín e Marcenaro (2010: 252) também concorda: «realmente». Em Ferreiro (2016-, consult. 21 jun. 2021) à locução «a feito» é atribuído o sentido «sen interrupción, decote», acrescentando-se: «Na realidade, esta locución ten un valor modo-temporal». Álvarez de la Granja (2005: 26), além deste sentido, considera, especificamente para a cantiga de Roi Queimado o sentido «Seguido, sen interrupción». O mesmo sentido foi considerado pela autora para a cantiga de Santa Maria 77 (METtMann 1986-1989, vol. 1, p. 252). 
que de Deus aquesto era, / foi chorand'e non riindo

a el e falou con ele / a onrra da Virgen Madre,

Non deven por maravilla / tẽer en querer Deus Padre...

Contando-lle tod'a feito / en qual maneira dormira

e en jazendo dormindo / a Santa Maria vira,

que lle mandou que fezesse / ssa eigreja, sen mentira

(METTMANN 1986-1989, vol. 3, p. 116)

O bispo e toda a gente deant' estando,

veend'aquest'e oynd'e de rijo chorando,

viron que miragre foi e non trasgeito;

porende loaron a Virgen afeito.

Da que Deus mamou o leite do seu peito...

(ibidem, vol. 1, p. 252)

Quanto aos dois exemplos colhidos na prosa, parece querer transmitir-se a ideia de não ser totalmente verdade, no caso da Crónica geral de Espanha, e de ser totalmente ou rematadamente «sandia», no caso da Demanda do Santo Graal. Em português atual usar-se-ia a expressão «ser completamente doido» para justificar comportamentos, dado haver a noção empírica, que contamina a linguagem, de a loucura ter graus. Curiosamente, numa das cantigas galego-portuguesas em que a locução ocorre, o contexto envolve igualmente a loucura. Trata-se da cantiga Por mui fremosa, que sanhuda estou, de Pero Meogo: «Non faç'eu torto de mi lh'assanhar / por s'atrever el de me demandar / que o foss'eu veer / <a la font'u os cervos van bever $>$ // Affeito me ten ja por sendia, / que el<e $>$ non ven, mas <ar> envia / que o foss'eu veer / <a la font'u os cervos van bever>» (COHEN 2003: 418). Neste caso, no entanto, o locução adverbial exprimiria a força das convicções do amigo da menina sobre ela («me ten $[\ldots]$ por sandia») a total certeza dele sobre a loucura dela.

Em ambas as cantigas de Santa Maria, encontramos o mesmo sentido de totalidade e perfeição: na primeira cantiga, conta-se como certos acontecimentos foram contados na totalidade e em pormenor, sem nada excluir, e, na segunda, o louvor à Virgem foi feito sem reservas, nem dúvidas sobre os acontecimentos; total, completo, rendido.

Também no caso da cantiga de Airas Moniz D’Asme Pois mi non val d'eu muit'amar, podemos considerar o mesmo sentido de totalidade, por oposição a parcialidade, uma vez que se trata da revelação da identidade da mulher amada, que o sujeito considera ter feito descrevendo-a. Ou seja, o sujeito considera que a descrição feita corresponde à total revelação ou nomeação 
da mulher amada: «Da que á melhor semelhar, / de quantas no mund'ome vir, / e mais... / das que home falar oir, / non vo-la ei chus a dizer: / quen quer xa pod $[\mathrm{e}]$ entender. Já chus seu nome non direi / ca a feito mi-a nomeei» (MIRANDA 2004: 140$)^{56}$.

No caso da cantiga de Roi Queimado, creio podermos considerar este mesmo significado para a locução em estudo, o que faz especial sentido tendo em consideração a cantiga de Joam Soares Coelho anteriormente estudada, ou seja, a cantiga em que o sujeito rejeitava a ideia de «Don Estevan» ver mal, para defender a ideia de nada ver, a ideia de ser completamente cego. A primeira estrofe da cantiga de Roi Queimado parece conter, na verdade, uma alusão a esta tomada de posição na cantiga de Coelho, e a locução «a feito» terá ajudado a fazer a alusão que já o adjetivo «cego», por oposição a «ver mal», fazia. «oi dizer $[\ldots]$ que a feito / sodes cego», na primeira estrofe, significa, portanto, ouvi dizer que «sois totalmente cego». Na segunda estrofe, se considerarmos a conjetura feita, «que a feito [non] sodes cego» significa: «que não sois completamente cego». $\mathrm{Na}$ terceira estrofe, estando a locução a modificar o verbo «dormir», o sentido será o de sono profundo, total adormecimento («pois me deito / e dormesco e dormio ben a feito»), ideia que aliás é preparada e reforçada pela sequência de verbos ligados ao sono (deito-me, adormeço, durmo profundamente) em gradação que creio intencional, já explicarei por que razão. A associação entre a locução adverbial «a feito» e o verbo «dormir», neste contexto, confirma a necessidade de lhe atribuir significado diferente de «realmente, de facto $\gg^{57}$.

A locução adverbial de modo «a son», que ocorre no verso eliminado por R. Lapa, creio ser uma invenção de Roi Queimado para sintetizar o que explicita anteriormente: que «Don Estevan» compensa a cegueira ouvindo muito bem («oi dizer $[\ldots]$ que a feito / sodes cego, mais dix'eu que mui ben / oides cada que vos cham'alguen $[\ldots]$ vós: que a feito [non] / sodes cego, e dix'eu log'enton $[\ldots]$ / que nunca vos ome diz nulha ren / que non ouçades), ou seja, que «vê com os ouvidos»: «que assi veedes vó-lo a son». Aquilo que «Don Estevan» vê «a son», isto é, aquilo que «Don Estevan» ouve tão bem que é como se visse, sugere-o inicialmente o sujeito quando indica a situação em que

56 Na cantiga Alvar Rodriguiz dá preço d'esforço, de Estêvão da Guarda, não deverá tratar-se da locução adverbial, como se considera em Ferreiro (2016-, consult. 21 jun. 2021), «a feito», mas do substantivo «feito» precedido de preposição: «teno / seu coraçon en se parar a feito» (PAGANI 1971: 139). Ou seja, tem decidido preparar-se para um feito. Veja-se Lorenzo (1977: 642). Por outro lado, deve considerar-se a possibilidade de um sentido específico para a expressão «parar a feito» ou «pararse a feito» (GONZÁLEZ GARCIA 2005: 92-93).

57 É sintomática disto mesmo a paráfrase em CMGP («durmo a sono solto»), que, talvez inadvertidamente, atribui a esta ocorrência da locução sentido diferente do sentido atribuído às outras ocorrências da mesma locução adverbial. 
«Don Estevan» o ouve: quando o sujeito dorme profundamente. Depois, o que ouve é sintetizado num pronome («veedes vó-lo»), para ser revelado na finda («quen / assi ouve como vó-lo sarmon»), embora metaforicamente. Não será decerto a um sermão que se refere o sujeito da cantiga, dado referir-se a um som por ele produzido quando se encontra profundamente adormecido. Além de que será ouvido ao longe, já que o sujeito procura provar a acuidade auditiva de $\ll$ Don Estevan». $\mathrm{O} \ll$ sarmon ${ }^{58}$ a que se refere o sujeito da cantiga de Roi Queimado tratar-se-á portanto de som emitido durante o sono profundo de alguém que, ouvido ao longe, pareça um sermão, ou a que alguém possa referir-se por troça designando-o por sermão... Creio tratar-se da descrição do som produzido por alguém que ressona.

Embora tenha considerado a locução «a son» uma invenção de Roi Queimado, que assim, como costumam os criadores, força a língua a exprimir mais impressivamente a ideia literária que desenvolve na cantiga, há, num passo da Crónica geral de Espanha, outra locução que podemos aproximar desta:

E, quando os o conde vyo, prouguelhe muito com elles e mandou por todos aqueles que entendeu que o ajudariam; e estes foron muytos e de muytos logares. E desy postou sua fazenda de tal guisa que os passou todos ẽ naves em sõo de mercadores aaquẽ mar, poucos e poucos, e nũca nem hũu homen pode cuidar se nom que eram mercadores (CINTRA 1984, vol. 2, p. 324).

«em sõo de mercadores» significa «disfarçados de mercadores», portanto, trata-se aqui mais do aspeto que do som, mas mantém-se a ideia de substituição: na cantiga, o som substitui a visão; na Crónica, o aspeto de mercadores substitui $\mathrm{o}$ aspeto de militares.

A cantiga de Roi Queimado retoma a abordagem feita na de Joam Soares Coelho Don Estevan fez sa partiçon, num claro diálogo com esta sátira, embora sem a mesma subtileza. Enquanto Coelho se ocupa de criar expetativas de defesa de «Don Estevan», afirmando discordar de quem considera que ele vê mal para logo depois as defraudar, com efeito cómico, mostrando-se convicto de que $«$ Don Estevan» nada vê, Roi Queimado é mais explícito, quando refere a opinião segundo a qual «Don Estevan» é totalmente cego («a feito sodes cego»). Esta opinião coincide com a opinião expressa pelo sujeito de Joam Soares Coelho na cantiga referida, o que aproxima estreitamente as duas sátiras.

58 R. Lapa (1970a: 612) tomou o vocábulo no sentido literal: «sarmon = sermão», assim como acontece em CMGP ( «Esta referência ao sarmom não é muito clara. Talvez Roi Queimado queira dizer que, por pecar, ele ouve depois atentamente o sermão»); Em Lorenzo Gradín e Marcenaro (2010: 255) considera-se adicionalmente o significado «conversazione». 
Também o efeito cómico as aproxima, embora, mais uma vez, o grau de subtileza seja diferente. Roi Queimado começa igualmente por criar expetativas, na primeira estrofe, que mantém na segunda e subverte com elemento da intimidade (ressonar) na terceira estrofe, provocando provavelmente o riso. De facto, na primeira estrofe, Roi Queimado usa abundante vocabulário e expressões de âmbito jurídico gerando a expetativa de um grau elevado de sátira, que mantém na segunda estrofe, onde se concentram os elementos de efetiva sátira. Na terceira estrofe, no entanto, é introduzido, para justificar a opinião satírica expressa na segunda estrofe, o relato de uma experiência pessoal, que, pela surpresa de incluir elemento da intimidade, terá provocado o riso.

Note-se que também Joam Soares Coelho, na cantiga já referida, justifica uma opinião satírica acerca de «Don Estevan» (que ele nada «vê») com o relato de uma experiência pessoal (tê-lo visto incapaz de sair de um tojal junto a Amarante). Roi Queimado não se limita portanto a dialogar com Joam Soares Coelho nesta cantiga, referindo a opinião por ele expressa acerca da cegueira total de «Don Estevan», uma vez que reproduz igualmente a dispositio da composição e, em parte, a inventio.

Na primeira estrofe, invocando a situação de julgamento de uma ação contra «Don Estevan», o sujeito dá conta da acusação: «Don Estevan» é completamente cego. Colocando-se do lado da defesa, o sujeito concorda com a acusação, uma vez que não a refuta, apenas contrapõe que o acusado compensa o defeito de visão com o sentido da audição («cada que vos cham'alguen»). Evidentemente, esta é uma falsa defesa que terá ela própria provocado o riso, não só por não haver refutação da acusação, mas por a compensação do defeito (ouvir cada vez que alguém chama) ser ridiculamente comum. Ou seja, o sujeito defende o acusado atendendo a que ele compensa um defeito grave com uma qualidade comum: não vê nada, mas ouve chamar pelo nome. Considerando que a cegueira de que aqui se trata será certamente a mesma cegueira de que se fala na cantiga de Joam Soares Coelho, ou seja, não uma cegueira concreta mas a incapacidade de entendimento, o que Roi Queimado nos mostra de «Don Estevan» é, mais uma vez, o retrato de um homem estúpido e, como veremos também a seguir, incapaz de argumentação.

Na segunda estrofe, o sujeito dá conta da defesa («vos oi [...] dizer por vós») de «Don Estevan», segundo o qual não seria completamente cego («que a feito [non] / sodes cego»), que é previamente considerada pelo sujeito um erro de argumentação ou de defesa: «vos oi eu oje mal sén dizer por vós». Esta condenação não é de espantar, por duas razões. Primeiro, pela tibieza: dizendo não ser completamente cego, assume que vê mal, ou seja, que a sua capacidade de entendimento é limitada. Depois, por contrariar a linha defensiva oferecida na primeira estrofe pelo sujeito da cantiga de Roi Queimado (é cego, sim, mas 
ouve). Também não é de espantar a ironia com a capacidade de «Don Estevan» ouvir o que se lhe diz, pois ignora a argumentação oferecida pelo sujeito: «e dix'eu log'enton / esto que sei que vos a vós aven / que nunca vos ome diz nulha ren / que non ouçades». Ou seja, esta parte da segunda estrofe significaria o contrário do que afirma, como é próprio da ironia: «Don Estevan» ignora a defesa que dele faz o sujeito, optando pela simples e tola negação das acusações que lhe são feitas (és completamente cego vs. não sou completamente cego, logo sou parcialmente cego), consequentemente, ao contrário do que, com aparente boa vontade, o sujeito procurou apresentar em defesa de «Don Estevan», este não ouve o que lhe dizem.

Roi Queimado continua nesta estrofe a compor o retrato de um homem estúpido, incapaz até de se defender, uma vez que, quando acusado de ser completamente cego, isto é, de ser completamente idiota, não consegue defender-se melhor do que dizer que não o é completamente, de onde se subentende que o é parcialmente. Com a agravante de lhe ter sido oferecida uma linha de defesa alternativa que, embora armadilhada por admitir limitações, poderia, ainda assim, ser melhor solução argumentativa.

Tal como noutras cantigas já estudadas, especialmente a cantiga Don Estevan, que lhi non gradecedes, também de Joam Soares Coelho, percebe-se, nesta cantiga de Roi Queimado, em pano de fundo, o ambiente da corte, a convivência dos seus frequentadores. Na terceira estrofe, alude-se mesmo à convivência de pessoas que, cruzando-se na corte, nela pernoitam (e por vezes ressonam ... ). Retomando a ideia de que «Don Estevan» não vê mas ouve, o sujeito leva-a um pouco mais longe afirmando que «Don Estevan» vê com os ouvidos, vê pelo som («veedes $[\ldots]$ a son»), ou seja, compreende o que se passa pelo que ouve. Há, pois, um momento em que o visado da cantiga vê, isto é, sabe o que se passa ( «á sazon / que veedes ${ }^{59}$ ) porque ouve. Esse é o momento em que o sujeito se deita, adormece e dorme profundamente («quando pois me deito / e dormesco e dormio ben a feito») produzindo um som que, ao longe, poderia confundir-se com um sermão ( «quen / assi ouve como vó-lo "sarmon"») ou simplesmente ao qual poderia assim chamar-se, com intenção cómica.

Note-se que não creio ser o riso a única intenção desta terceira estrofe. Há nela duas linhas satíricas: uma que dá continuidade à que já encontrámos 
nas estrofes anteriores e outra que já encontrámos em cantigas do mesmo conjunto satírico. A primeira é a de mostrar a capacidade de entendimento («á sazon / que vedes») de «Don Estevan» limitada à interpretação de um pseudodiscurso («sarmon»), reduzida à identificação de um som noturno, produzido durante o sono, como o som de alguém que ressona. Ou seja, mais uma vez, o retrato de alguém de entendimento muito limitado. A exclamação final («confonda Deus quen cego chama quen / assi ouve como vó-lo «sarmon») deve portanto ser entendida como irónica, uma vez que não se pretende dizer que a interpretação deste «sermão» é prova de grande inteligência, mas prova da capacidade máxima de «Don Estevan» e de ínfima inteligência.

A segunda linha satírica, afim da cantiga Don Estevan, que lhi non gradecedes, de Joam Soares Coelho ${ }^{60}$, é a da inconveniência das declarações no ambiente de corte, que esclarece a insistência na alusão a declarações ouvidas ( «oi dizer por vós»). Assim como esclarece a alusão ao efeito das declarações no sujeito: «E assanhei-m'eu». Também na cantiga Don Estevan, que lhi non gradecedes, de Joam Soares Coelho, «Don Estevan» é acusado de inabilidade no jogo social, de incapacidade de criticar de bom humor, sem provocar mal-estar, sem provocar precisamente a «sanha» do criticado. Ei-lo aqui comentando ter ouvido alguém ressonar durante a noite, sem a necessária habilidade para que o ridicularizado não se melindre. Ainda por cima, alguém que se prestara a defendê-lo de acusações desagradáveis. É, de novo, a inabilidade social de «Don Estevan», em contexto de corte, que vemos zombeteiramente exposta nesta estrofe, desta vez por Roi Queimado. E é de novo Joam Soares Coelho que vemos inspirar Roi Queimado nesta cantiga, onde se encontram ligações estreitas a ambas as cantigas compostas por Coelho, contra «Don Estevan».

Não se vislumbra, na cantiga em análise, nenhuma alusão direta às questões políticas que cruzam as cantigas já analisadas do conjunto dedicado a «Don Estevan», embora a alusão direta à cantiga Don Estevan fez sa partiçon, de Coelho, traga para o palco desta a questão política que ali se aborda. Apesar disto, a cantiga parece afastar-se deste conflito e centrar-se na sátira às incapacidades de «Don Estevan»: as de argumentação e as de jogo social, acenando-nos com um ambiente de corte que lembra o da cantiga Don Estevan, que lhi non gradecedes, de Coelho, anterior à guerra civil. Mas precisamente a dependência da cantiga de Queimado em relação às cantigas de Coelho pode indicar que tal associação seja ilusória. Na verdade, se Queimado produziu esta cantiga aproveitando a inventio das duas cantigas de Coelho, será natural que o texto reflita os modelos quanto

\footnotetext{
60 Recordo que, ao analisar esta cantiga, me pareceu haver razões para a considerar a primeira do conjunto, composta ainda em 1244, após a eleição do arcebispo de Braga, e para considerar que visava não só Joam Viegas, mas também o rei, por ter favorecido a eleição do Arcebispo.
} 
ao ambiente de composição, embora o objetivo satírico tenha sido minar a credibilidade, influência e poder do arcebispo de Braga. Esta dependência dos modelos pode ter tornado a cantiga de Queimado numa espécie de espelho deformador, na medida em que, pelo menos em parte, poderá refletir uma realidade que já se alterou, após os acontecimentos profundamente transformadores da guerra civil. Dada a alusão direta à cantiga Don Estevan fez sa partiçon, de Coelho, a cantiga de Queimado será necessariamente posterior, provavelmente de tempo subsequente à morte de Sancho II e talvez mesmo de uma altura em que se tinha tornado claro até que ponto Joam Viegas de Portocarreiro e restante clero tinham sido enganados. Mas o ambiente de convívio na corte refletido na cantiga poderá depender mais de um modelo composto antes da guerra (Don Estevan que lhi non gradecedes, de Coelho) do que do efetivo restabelecimento de tal normalidade, na sequência da guerra.

Nas duas cantigas do conjunto marcado pelo vocativo «Don Estevan», de que em seguida me ocuparei, as mudanças relativamente às cantigas analisadas até ao momento são substanciais. Tanto pelas novidades nelas introduzidas, quanto pela ausência das recorrências notadas nas anteriores.

Mas também nestas cantigas não se verificam alusões diretas aos acontecimentos da guerra civil que dividiu a nobreza em dois partidos. Terão, portanto, sido compostas em momento posterior ao da bipolarização política e militar decorrente da presença do Rei e do Conde em Portugal. Digo posterior e não anterior, porque creio haver certa dependência criativa, conforme adiante explicarei, entre estas duas cantigas e a cantiga Don Estevan fez sa partiçon de Joam Soares Coelho, que considerei posterior à guerra civil.

Enquanto nas cantigas estudadas anteriormente se insiste no verbo «ver», que assume mais de um sentido, nas duas que se seguem, isto não se verificará. O verbo «catar», semanticamente próximo de «ver», assumirá um papel relevante, no escárnio de Airas Peres Vuitorom, mas não em substituição do verbo «ver», uma vez que não transmite nenhum dos sentidos servidos por «ver» nas sátiras anteriores.

Apesar da omissão habitual do jogo com o verbo «ver», há, em ambos os textos, além do vocativo «Don Estevan», pontos de contacto suficientes com as restantes cantigas para não se levantarem dúvidas quanto a tratar-se do mesmo visado. Confirma-se, por outro lado, mais uma vez, que a «cegueira» de «Don Estevan» é metafórica.

A grande novidade nas sátiras de Tenoiro e Vuitorom, cuja edição e estudo se segue, é o elemento temático da fúria («sanha»), exclusivo de ambas as composições. «Don Estevan» é mostrado nelas a agredir e maltratar pessoas que, estando ao seu serviço, encontram ou poderão encontrar razão neste comportamento para se afastarem. 
Devemos notar, por outro lado, que as duas cantigas que se seguem têm significativos elementos em comum com a história de frei Gonçalo de Amarante, a que Coelho parece aludir na cantiga Don Estevan fez sa partiçon. De acordo com o relato mais próximo dos eventuais acontecimentos, isto é, a Vida de São Gonçalo incluída no Flos sanctorum de 1513, quando frei Gonçalo regressa, após 14 anos de viagem, para retomar a igreja que o arcebispo Estêvão Soares lhe atribuíra e que confiara ao sobrinho, este agride-o com um pau, nega-lhe até alimento e atiça-lhe os cães de caça para que o mordam. Embora usados de forma diferente, encontramos estes elementos nas cantigas de Vuitorom e Tenoiro que se seguem: agressão com pau e cães, além do paralelismo entre a situação de frei Gonçalo, que beneficiou o sobrinho e foi por ele traído, agredido e abandonado, e a de Joam Viegas, ou «Don Estevan», que foi beneficiado por Sancho II tendo-o depois traído e «escorraçado» do reino. Acresce que a igreja usurpada por sobrinho a tio se localiza em Riba de Vizela, topónimo também identificador da linhagem mais fiel a Sancho II, a de Martim Fernandes de Riba de Vizela, seu amo, casado com Estevainha Soares, irmã de Estêvão Soares. Recordo ainda que a história de Gonçalo constituía um embaraço para o arcebispado de Braga, na medida em que não só houve conivência na usurpação da igreja ao santo pelo sobrinho, como não houve reparação do mal, aquando do regresso de Gonçalo.

Apesar destas coincidências, se a lenda de Gonçalo de Amarante que chegou a nós corresponde a um relato de acontecimentos que corresse e se refletisse nestas cantigas, não parece haver o objetivo de a usar como chave para a interpretação das sátiras de Vuitorom e Tenoiro, que se seguem. Nestas, vemos «Don Estevan» agredir, com pau, pessoa a ele vinculada por juramento e vemo-lo deixar à míngua os que o servem; pessoas dependentes, dos quais depende por ser incapaz de se valer sozinho e em cuja recompensa pretende economizar sob qualquer pretexto. Não creio, portanto, que o relato sobre a vida de frei Gonçalo deva considerar-se uma chave fundamental na interpretação dos textos de Tenoiro e Vuitorom que se seguem. Mas as coincidências assinaladas, em articulação com a referência na cantiga de Coelho, já explicada, obriga-nos a considerar a influência de um relato de acontecimentos que deveria ocupar as atenções dos círculos nobres e religiosos, e que envolvia o arcebispado de Braga, evidenciando a incapacidade deste para lidar com assuntos diplomaticamente, talvez até administrativamente, delicados.

Veja-se o passo da Vida de São Gonçalo a que acabo de me referir, na edição de C. Sobral da versão de 1513:

Tornãdo o tyo aa ygreja muy asperamẽte vestido, desfecto do caminho e desemparado das forças corporaes, faminto e sedorento, polla vilhice e fadiga grãde do caminho abayxado e encostado em seu bordõ, aa porta de 
sua ygreja, seendo o sobrinho a comer com sua amiga, chegou. E cõ aquella voz que elle pôde começou de bradar, dizendo:

- Esmolla ao prove por amor de Deos!

Os carvos e os alaãos, os podengos, ouvida a voz do pobre, fortemẽte ladrando vierõ aa porta e ao prove desejavã de morder. E elle provou outra vez atee tres vezes, dizẽdo:

- Esmolla ao prove por amor de Deos!

E os caães cõ mais yra ladrando o fizerõ muyto maravilhar. E os servidores do falso confirmado vierom aa porta per seu mandado e cõselharõ ao prove que se fosse à aldea mais chegada e hy pedisse esmolla, que nõ era costume daquella ygreja aos taaes proves cõ esmolla socorrer. E elle bradando que elle era o abade daquella ygreja dizia que tal regimẽto nõ deixara a seu sobrinho em sua partida. E veo seu sobrinho e ouvĩdo suas palavras abrio a porta e cõ o cajado que na maão tinha cruelmente o ferio. Mas elle humildosamẽte respõdendo, dizia:

- Polla ventura nõ te criey eu de moço pequeno? Polla vẽtura nõ te dey eu exẽplos de saude e salvaçõ? Polla vẽtura nõ me prometeste, apertando a minha maão dereita, que das fazendas desta ygreja farias como me viste fazer?

E o sobrinho cõ mayor yra o feria e os caães lhe punha que lhe mordessem e cõ grãdes brados o vituperou e começou de jurar que, se elle seu tyo destas cousas falasse, que a poder de pancadas e mordeduras de caães per força lhe faria sayr a alma do corpo. E emtõ Sam Gonçallo, dãdo muytas graças a Deos, foy-se pollos lugares darredor semeando a palavra de Deos e cõvocando aa terra dos viventes per enxemplos e palavra os moradores daquella terra (2000: 608-609). 


\section{Mem Rodrigues Tenoiro}

I 1 Don Estevan achei noutro dia ${ }^{61}$ mui sanhudo depos un seu om' ir e sol non lhi pôd'un passo fogir aquel seu ome depos que el ia

5 e filho'-o i pelo cabeçon e feriu-o mui mal dun gran baston que na outra mão destra tragia.

II E Don Estevan assi dizia a nós que lho non leixássemos ferir:

$10-\ldots$ mais quero-vos eu ora descobrir com' este vilão migo vivia: mais era eu seu ca era el meu e muit' andava mais empos el eu ca el pos mi, peró xi m’el queria.

15 E o vilão enton respondia com'agora podedes oir: - Mui gran mal fazedes en consentir a est' ome tort'o que mi fazia ca de-lo dia en que o jurei

20 sempre a gran coita deante lhandei e el sempre deante me metia.

E veed'ora, por Santa Maria, IV se ei poder de co el mais guarir ca me non poss' un dia del partir

25 de mi dar golpe de que morreria dun gran pao que achou non sei $u$ e pois s'assanha non cata per $\mathrm{u}$ feira con el, sol que lh' ome desvia.

$61 \quad \mathbf{B 1 4 7 2} / 1083$ Aparato crítico - 1. Como noutras cantigas, o copista de v escreve estauam, cancelando posteriormente $o \ll a \gg$ errado e substituindo-o por um «e», na entrelinha superior; noutre в; 7. maо в maa v O copista de v hesitou na cópia desta palavra, que termina com um «s» cancelado. A penúltima letra parece um «a», mas está igualmente borrada, podendo indicar a vontade de transformar um $\langle a \gg$ num $\langle 0 \gg .8$. don estenã в donne stauã V; 9. auos V; 10. toug B; 11. vilano B iulão V; 16. pododes B 18 . Aestome corto B; 27 . Verso ausente em B, devido provavelmente a um sault du même au même («hu» no final dos vv. 26 e 27) - A presente edição difere da de R. Lapa (1970a: 
O verbo «catar», com uma única ocorrência neste texto, tem sentido concreto (olhar), e as acusações de «cegueira», com diversos sentidos, apoiadas no verbo «ver», não se encontram nesta cantiga. Mas há nela um outro elemento relacionado com a visão, que faz perfeita ligação com as alegações anteriormente consideradas, segundo as quais «Don Estevan» via mal. O elemento a que me refiro tem passado despercebido, porque R. Lapa, não o reconhecendo, emendou o texto e obliterou-o até à data. Refiro-me ao adjetivo «torto», que o filólogo transformou no substantivo «torto» alterando o sentido do verso $18^{62}$. Onde os manuscritos apresentam a lição «Mui gran mal fazedes en consentir a est'ome tort'o que mi fazia», R. Lapa editou: «Mui gran mal fazedes en consentir a est'om'o torto que mi fazia». Naturalmente, o erro que R. Lapa julga estar a emendar nada tem de injustificável; a facilidade de confusão pelos copistas de um «e» com um «o», e vice-versa, tornaria perfeitamente aceitável o raciocínio de R. Lapa, se a emenda fosse necessária, como certamente lhe pareceu ser. No entanto, o adjetivo «torto», cujo significado era «cego de um olho» (zarolho) adequa-se ao retrato de um homem repetidamente acusado de ver mal, ou seja, como vimos, de ser incapaz de entendimento.

Veja-se o seguinte exemplo da utilização do termo com este mesmo sentido: «E foi molher do conde dõ Reymõ de Sam Gil de Proença, que era torto de hũu olho» (CINTRA 1984, vol. 3, p. 411). Nos Livros de Linhagens, há uma figura histórica cuja alcunha, $o$ Torto, é também explicada com referência à perda de visão: «dom Joham, e foi cego de ũu olho, e por esto lhe chamarom dom Joham, o Torto» (MATTOSO 1980, vol. II/1, p. 144).

\footnotetext{
123-124) no verso 9, onde mantive a lição dos manuscritos, atribuindo a «Don Estevan» o pedido aos demais para que o impedissem de ferir o vilão, assim como a adversativa «mais», que introduz a justificação da fúria. Ou seja, «Don Estevan» pede que o impeçam de agredir, mas justifica a fúria que o leva a fazê-lo. Ao contrário de R. Lapa, considero que, no verso 14, «peró» (per hoc) não tem valor concessivo nem adversativo, mas causal, introduzindo a razão de o vilão querer servir «Don Estevan», segundo a opinião deste. Esta edição também difere da de R. Lapa no verso 18, onde igualmente mantive a lição dos manuscritos («est' ome torto») que R. Lapa emendou («est' om' o torto»), convertendo o adjetivo «torto» (injusto, traidor / zarolho) no, mais comum, substantivo «torto» (injustiça). Mais uma vez, não julgo necessário fazer integrações conjeturais, para acrescentar uma sílaba ao verso 16, como R. Lapa («como[o] agora») e CMGP («pode[re]des») fizeram. No verso 19, como R. Lapa, julgo necessário fazer uma emenda à lição que ambos os manuscritos apresentam (в: «Ca delo dia ẽ q̃o eu sey»; v: «ca delo dia enq̃o o eu sey»). O facto de não ter encontrado nenhuma exceção à regra de a locução temporal «de-lo dia en que» introduzir um verbo no pretérito perfeito aponta para um defeito de transmissão. O sentido do verbo «saber», no contexto da cantiga, não se acomodaria, por outro lado, com facilidade. R. Lapa conjeturou «ca, dê-lo dia en que o eu $[\mathrm{u}]$ sei», emenda cujo sentido me parece igualmente difícil de aceitar, considerando o contexto da cantiga. Em CMGP, sem explicações, optou-se por manter, neste caso, a lição dos manuscritos, ao contrário de todos os outros casos, em que foram adotadas as emendas de R. Lapa. A minha proposta de emenda (eu sei > iurei) considera um erro de copista e recupera uma lição enquadrável na interpretação geral do texto.

Lapa (1970a: 123). Em CMGP aceita-se a emenda.
} 
Mas o recurso a este adjetivo para qualificar um homem incapaz de ver ou de compreender, conforme as acusações que lhe são dirigidas, nas cantigas de Coelho e Queimado, é ainda uma outra forma de aludir à mesma figura histórica cujo nome foi usado para renomear ironicamente Joam Viegas de Portocarreiro chamando-lhe «Don Estevan». A alcunha Torto foi usada por Soeiro Pires Torto $^{63}$, pai de duas figuras importantes na vida de Sancho II: a ama, Estevainha Soares, e o muito poderoso arcebispo de Braga, Estêvão Soares. As alcunhas dos pais eram herdadas pelos filhos, pelo que, embora os Livros de Linhagens não o registem, ambos os mencionados filhos de Soeiro Pires (D. Estevainha Soares e D. Estêvão Soares) terão também sido conhecidos pela alcunha do pai. Ou seja, ao usarem o nome «Don Estevan» (do arcebispo Estêvão Soares) para ironicamente, e cifradamente, referirem o arcebispo Joam Viegas de Portocarreiro, os trovadores poderiam trocá-lo pela alcunha herdada do pai: Torto. Creio ser o jogo que Tenoiro faz neste texto, onde, ao omitir as acusações de «cegueira» e ao desenvolver a temática da sanha, explora preferencialmente o significado «injusto» que a palavra «torto» também tinha. Vuitorom acompanhará (ou iniciará), na cantiga que analiso de seguida, esta deslocação.

O duplo sentido do adjetivo (injusto e zarolho) não deixa de ser referido na generalidade de dicionários e glossários, de que deixo o exemplo do glossário de La traduccion gallega de la Cronica General y de la Cronica de Castilla e também, para o castelhano, o Diccionario critico etimológico castellano e hispánico (COROMINAS e PASCUAL 2006-2007), onde se reconhece para o correspondente adjetivo «tuerto» tanto o sentido de «injusto», quanto o sentido de «zarolho», que a palavra ainda tem em castelhano:

TORTO2 'tuerto, falto de la vista de un ojo' (propiamente 'de vista torcida'), con el mismo origen que el anterior. Una vez: 407.4 (c. 256) "conde dõ Ramõ... que era - de hũu ollo" (LORENZO 1977: 1267).

Tuerto adj. 'torcido'[Berceo], 'injusto'[Apol.]; 'bizco’ant. [1. a Crón. Gral., en RFE VII, 33], propriamente 'de vis torcida'; de donde luego 'que sólo tiene un ojo [J. Ruiz], com. casos paralelos de evolución semántica, RDR III, 469; m. 'agravio, injusticia'[Cid; Berceo; Alex., 197, 231, 850; Sem Tob 276, etc (COROMINAS e PASCUAL 2006-2007, vol. 5, p. 554).

63 Embora no índice onomástico, Mattoso (1980, vol. II/2, p. 366) registe «Torto», no corpo do texto lê-se «Torta». No foral de Salvaterra é referido Martim Pires Torto: «Tal como o anterior, concedido aos povoadores e ao bispo, o foral de Salvaterra deixa a este uma certa margem de controle, permitindo-lhe a intervenção na escolha dos alcaides e juízes, que deverá no entanto ser confirmada pelo concelho, ao mesmo tempo que implicitamente reconhece a anterioridade da organização territorial, ao colocar na lista de confirmantes - e, anote-se, não como testemunha, mas logo abaixo dos bispos e cónegos - Martim Pires Torto, «qui primus incepit populare eam», «quem primeiro a começou a povoar» (FERNANDES 2010: 223-224). 
Embora para o castelhano, como vimos, J. Corominas reconheça que o adjetivo «torto» tem o sentido de «injusto»; na Lírica Galego-Portuguesa, é mais comum encontrá-lo associado ao substantivo ou a locuções adverbiais. Mas pude encontrar uma segunda ocorrência do adjetivo «torto», com o sentido de injusto, associado a pessoa concreta e identificada: precisamente o arcebispo de Braga, Joam Viegas de Portocarreiro, sucessor, embora não imediato, no arcebispado de Braga, do referido Estêvão Soares Torto, filho de Soeiro Pires Torto.

Na famosa cantiga A lealdade da Bezerra pela Beira muito anda, de Airas Peres Vuitorom ${ }^{64}$, o termo «torto» ocorre duas vezes na primeira estrofe, ( $\ll$ Non ten Sueiro Bezerra que tort'é en vender»; «non é torto de vender»). Também no início da segunda estrofe, o substantivo ocorre em acusação $d$ «o que vendeu Marialva» (《diz que non fez torto o que vendeu Marialva»). Mas, nesta mesma estrofe, encontra-se o adjetivo a qualificar pessoa indicada mediante pronome relativo (quen): «ca lhe diss'o arcebispo un vesso per que se salva: - Estote fortes in bello et pugnate cum serpente; poren diz que non é torto quen faz traiçon [e] mente ${ }^{65}$. O termo não volta a ocorrer no resto da cantiga, e creio concentrar-se nele um jogo que implica diversos sentidos: o nome próprio Torto, alcunha do pai de Estêvão Soares, que serve para nomear Joam Viegas, nas cantigas que a «Don Estevan» são dirigidas; «zarolho», ou seja, com défice de visão ou perceção, e injusto ou traidor.

Incentivando à luta, nomeadamente contra a tentação da deslealdade e a traição, a que a serpente estaria vulgarmente associada pelo papel assumido no pecado original, o Arcebispo faria uma boa demonstração de contradição entre palavras e atos, na qual contradição «o que vendeu Marialva», igualmente desleal e traidor, encontraria alívio para a própria consciência. A conclusão é, como no resto da cantiga, irónica e significa o contrário do que é afirmado: «non é Torto» quen faz traiçon [e] mente. Ou seja, foi Torto (leia-se o arcebispo de Braga, Joam Viegas, renomeado «Don Estevan») quem fez traição e mentiu, como todos os que entregaram os castelos, embora com versos latinos incentive à lealdade fazendo o contrário do que diz. Note-se que, nesta estrofe, a conclusão para «o que vendeu Marialva» já tinha sido estabelecida logo no início; pelo que seria repetitiva a conclusão do final do verso, se a entendêssemos dirigida à mesma figura e não, como julgo, ao próprio Arcebispo, aqui tratado pela alcunha (Torto) de Estêvão Soares, que serve para o renomear, noutro conjunto de cantigas:

64 Lapa (1970a: 130-132). Esta sátira contra os alcaides que, tendo jurado lealdade ao rei Sancho II, entregaram os castelos ao conde de Bolonha apoiando-se no beneplácito clerical, foi composta durante a guerra civil.

65 Ibidem. Na interpretação que Díaz de Bustamante (2007: 224-225) faz da segunda estrofe desta cantiga, é esquecido o papel do arcebispo Joam Viegas na deposição de Sancho II. 
E poren diz que non fez torto o que vendeu Marialva, ca lhe diss'o arcebispo um vesso per que se salva:

- Estote fortes in bello et pugnate cum serpente;

poren diz que non é torto quen faz traiçon [e] mente.

(LAPA 1970a: 130)

Voltando à cantiga em estudo, a integração que R. Lapa faz no verso 19 é exigida tanto pela sintaxe quanto pelo sentido. Ambos os manuscritos apresentam o verbo «saber» no presente do indicativo («eu sey») e o filólogo, provavelmente considerando que a locução «de-lo dia en que» exige o pretérito perfeito, emenda para obter o verbo «usar», neste tempo verbal: «ca, dê-lo dia en que o eu $[\mathrm{u}]$ sei $\gg$. Compreende-se que R. Lapa quisesse alojar no verso uma forma verbal no pretérito perfeito, como invariavelmente se verifica na sequência de «delo dia en que ( «delo dia en que eu naci», «delo dia en que m'eu quitei $»$, «delo dia en que vos primeiro vi », «delo dia en que a conhoci» etc.). Creio, no entanto, que tanto o verbo «saber $\gg$ quanto o verbo «usar» levantam obstáculos ao entendimento do texto.

A proposta de emenda feita na edição acima parte do princípio de que o copista do antecedente, ou outro antes dele, confundiu o «i $\ll \mathrm{e} \gg$, e um $\ll \mathrm{r} \gg$ com um $\ll \mathrm{s} \gg$, transformando $\ll$ iurey $\gg$ em $\ll$ eusey $\gg$. Este verbo faria, neste contexto, alusão ao vínculo de serviço que uniria o vilão a «Don Estevan» e que passaria por um juramento. De acordo com o vilão, teria sido desde o momento deste juramento, desde o princípio da relação entre os dois, portanto, que as agressões teriam acontecido. Deixo alguns exemplos do recurso ao verbo para referir estas vinculações.

E, por que todollos homẽes per a mayor parte se conformã a seu rey, assi em os bõos custumes como em os contrairos, poren todos se concordaron con elle enna vida e custumes, des o mayor fidalgo ataa o mais pequeno escudeiro e dos grandes bispos ataa os clerigos parrochiaaes, e ainda os poboos, dos mayoraaes regedores ataa os pequenos jurados, en tal maneira que todo homen conrrompeu o seu estado (CINTRA 1984, vol. 2, p. 291).

E entõ se meteo no castello de Mõte Aragon e fallou com dous seus fisi / cos, daquelles em que elle mais fyava, e deulhes juramẽto que de sua fazẽda nõ dissessem nem hũa cousa se nõ como lhes elle devysou.

(CINTRA 1984, vol. 3, p. 282).

Quando el rey vyo que aquelle Abueçã tam de coraçõ lhe fazia serviço e assi lealmente, fezeo seu privado muy mais chegado e honrrouho e fezelhe 
preito e jura, com cartas bem firmadas, que nũca lhe tolhesse aquella privãça nẽ fezesse ẽno reyno cousa sem seu consselho (CINTRA 1990: 27).

27. E depois, a gram tempo, veo seu irmão Argall e pedio-lhe mercee. E depois que a pedio, rogou todos seus ricos homẽes e fez cortes, e feze-os jurar a seu irmão todos (MATTOSO 1980, vol. II/1, p. 81).

e devê-lo a fazer, ca sodes seos vassallos e seos jurados, e se lho mais encobrides, seredes perjuradeos e desleaes ${ }^{66}$.

Este verso tem correspondência com o verso 14, onde a declaração de «Don Estevan $\gg$, , 'el queria $\gg$, deve ler-se à luz do mesmo vínculo e entender-se que o vilão o queria por senhor («peró xi m’el queria [por senhor] »).

Há ainda outro lugar do texto em que R. Lapa emendou, neste caso desnecessariamente, afastando-se da lição dos manuscritos. No verso 9, onde tanto o testemunho в quanto o testemunho v apresentam a lição «leixássemos», R. Lapa opta por editar «leixámos», considerando a lição dos manuscritos «forma evidentemente errónea ${ }^{67}$. O filólogo decide ainda que o discurso direto de $\ll$ Don Estevan $\gg$ teria início apenas depois da primeira palavra do verso 10: «a nós, que lho non leixámos ferir / mais: - Quero-vos eu ora descobrir».

O regresso à lição dos manuscritos, no verso 9, juntamente com a opção por atribuir a «Don Estevan» também a adversativa do verso 10, dá de «Don Estevan» um retrato mais interessante e complexo, na medida em que o mostra, após ter sido surpreendido em ato de agressão, a pedir ajuda para dominar a fúria com que ataca «un seu ome» («assi dizia / a nós que lho non leixássemos ferir»), ao mesmo tempo que mostra necessidade de apresentar justificações àqueles a quem pede esta ajuda («-... mais quer-vos eu ora descobrir $[\ldots] \gg)$. «Don Estevan» procura convencer de ser a seu pedido que a agressão se interrompe, ao mesmo tempo que procura apresentar-se humilde na relação com o vilão e dar deste uma imagem de interesseiro («mais era eu seu ca era el meu / e muit' andava mais empos el eu / ca el pos mi, peró xi m'el queria»), no que pode entender-se como uma paródia do discurso político. Neste caso, eficaz, a julgar pela acusação inicial do vilão, durante a qual dá conta da cedência às razões de «Don Estevan» daqueles a quem se dirige: «Mui gran mal fazedes en consentir / a est'ome tort'o que mi fazia».

66 Píel (1988: 190). G. Martin (1997: 201) reconhece que o «amor» jurídico não é exclusivo da nobreza: «On relèvera enfin que, dans le droit médiéval espagnol, l'amour ne s'est pas limité à signifier une relation politique propre à l'aristrocratie, mais qu'il qualifia également le lien du roi à - au moins - une partie des vilais, habitant les villes.»

67 Lapa (1970a: 123). Em CMGP adota-se a mesma emenda. 
Concentremo-nos em algum vocabulário mais necessitado de esclarecimento, a começar pelas palavras da família vocabular de «sanha», que é central nas duas cantigas finais de Tenoiro e Vuitorom. No caso desta cantiga: «sanhudo» e «assanhar-se». As referências à «sanha», ou seja, à ira são frequentes na cantiga de amigo e ocorrem também nas cantigas de escárnio e nas de amor. A sanha é o sentimento invocado para justificar represálias de qualquer natureza. Na prosa, justifica quase sempre atos de violência, como acontece nos exemplos que se seguem.

E o conde dõ Fernã Lainez foy muy sanhudo contra ella / e deulhe hũa palmada ẽno rostro (CINTRA 1984, vol. 3, p. 238).

E, com a grande sanha que tiinha daquellas pallavras que lhe avya dicto, foi contra elle e feriuho com a espada per cima do elmo, que lho cortou e quanto acalçou da cabeça, em guisa que elle foy muy mal ferido e perdeo muyto sangue (ibidem, p. 306).

E elle, com sanha, mandou fazer tres engenhos e poseos a tres portas da villa e fazialhes tam grande dampno que maravilha (CINTRA 1990: 82).

Não será, no entanto, despiciendo lembrar que as referências à «sanha» em textos de natureza jurídica mostram que o domínio dos impulsos com origem neste sentimento era visto como de importância capital no caso de pessoas com a responsabilidade de tomar decisões. Por exemplo, a Constituição XXI das Ordenações de Afonso II deixa estabelecido que qualquer sentença dada pelo Rei «con sanha» devia tardar 20 dias a ser executada (ALBUQUERQUE e NUNES 1988: 51). Há ainda outras referências à «sanha» em contexto político-legislativo que vale a pena considerar.

Mucho se deben los reyes guardar de la saña, et de la ira et de la malquerencia, porque estas son contra las buenas costumbres, et la guarda que deben tomar en sí contra la saña es que sean sofridos, de guisa que non les venza nin se muvan por ella 'facer cosa que les esté mal, o que sea contra derecho; ca lo que con ella feciesen desta guisa, mas semejaria venganza que justicia (JUAREZ BLANQUER e RUBIO FLORES 1991: 65).

E este Alaym Calvo nõ querya seer juiz nem querya ouvyr preitos nẽ julgar, mas, por que os homeens boos da terra o teverom por ben, ouveo de fazer per força. Mas, desque foy juiz, nõ usava de ouvyr preitos nem dar sentenças e husava mais em armas e de cavallarya. $E$ esto era por que se asanhava toste e nõ era paciente pera ouvyr os preitos dos que viinhã 
ante elle, o que nõ cõvem a nem hũu juiz que ha d'ouvyr os preitos (CINTRA 1984, vol. 2, p. 477-478).

E, seendo elle alcaide, aadur ou poucas vezes livrava preito per juizo, mas ante punhava em aviir os homeens per amizade e per amor, ẽnos preitos que viinhã perante elle, que nom per afrontallos per sanha de juizo. E, por esta razon, era muyto amado de todos e queryanlhe muy grande bem por este feito tam boo que fazia (ibidem, p. 481).

Na Primeira partida de Alfonso X, embora não seja referida a sanha, nem, na verdade, nenhuma motivação concreta, há advertências para que os bispos e outros «prelados mayores » se abstenham de comportamento violento:

Regla d'ordinhamẽto fez o apostolo Sam Paulo en que mostra que custumes e que maneyras deue a auer o que ha de seer esleito pera algũũ dos prelados mayores. $[\ldots]$ que sseia $[\ldots]$ mesurado en comer e en beuer e casto e sabedor e aposto e planador e demostrador da ley nẽ seia peleiador nẽ feridor nẽ cobijçoso e que sabha bẽ ordinhar sa casa (FERREIRA 1980: 221).

Ferida corporal nõ deuẽ ffazer os prelados que he ssegunda maneyra que diz ena ley ante desta assy como de mão ou de pee ou cõ algũa outra cousa qual quer a maa parte, nẽ por maa querença nẽ por que seiã mays temudos. Ca se ffezessem por algũa destas razões pecariã grauemẽte e deuẽ a auer pẽa por ende qual teuerẽ por bẽ seus mayores segũdo ho ffeyto da fferida for, de maneyra que seiã castigados e nõ aiã sabor de o ffazer outra vez. Mais per rrazõ de castigo que nõ deuẽ ffazer, bẽ no podẽ fferir aquelles sobre quẽ am poder pero nõ per ssas mããos, mais mandandoo ffazer a outro que o faça. E sse algũũ $\mathrm{cl}<\mathrm{er}>$ igo $<$ que $>$ nõ ouuesse ordẽ sagrada fezesse pela uentura o que nõ deuia, bẽ pode mandar o bispo a outro clerigo que o ffeyra dandolhy diciplinas cõ correas ou cõ pertigas ou cõ ssa maao mesuradamẽte, pero [nõ] ffosse grande erro que ffezesse (ibidem, p. 248-249).

Como se deduz desta advertência na Primeira partida, os castigos corporais de subalternos com vara («pertiga»), pelo menos em contexto clerical, eram comuns.

Devemos, no entanto, atentar precisamente no vocabulário usado na cantiga para designar o instrumento que serve a «Don Estevan» para agredir «un seu ome». São usadas duas palavras: «baston», em primeiro lugar, «pao», em segundo lugar. Mais exatamente: «baston», chama-lhe o sujeito da cantiga («e feriu-o mui mal dun gran baston / que na outra mão destra tragia»); «pao» chama-lhe o «vilão» («de mi dar golpe de que morreria / dun gran pao que achou non sei $u \gg$ ). 
A segunda palavra («pao») não é desconhecida dos cancioneiros, nem mesmo para indicar instrumento de agressão. É com vergastadas que Guilhade ameaça pagar a Lourenço por serviços prestados: «e logo o mandarei / pagar a [un] gran vilão que ei, / se un bon pao na mão tever.» ( «Muito te vejo, Lourenço, queixar» $)^{68}$. Também na prosa se colhem diversas ocorrências desta palavra, usada para referir um dos mais vulgares instrumentos de agressão. Deixo alguns exemplos:

Despois que aquelle Vetiza foi rey de Galliza, foi morar em Tuy, assi como lhe seu padre mandara. Estando hũu dia fallando cõ o duque Faxilla, ferio con hũu paao ẽna cabeça, de guisa que lhe fez hũa grande chaga, da qual morreo a poucos dias (CINTRA 1984, vol. 2, p. 288).

E começou outrossi de acusar os sacerdotes e de os acender em sanha com muitos doestos, e tragia-os mui mal. E ia assi come sandeu pera cada ũu e avolvia-os que matassem os apostolos. E dizia:

- Que fazedes que estades quedados aí tardinheiros, aí priguiçosos, porque nom imos desfazê-los todos e espedaça-los com nossas mãos?

E, des que houve dicto aquesto, filhou el primeiramente ũu pao do altar e comecou el primeiramente de os ferir e matar (CEPEDA 1989, vol. 1, p. 110).

E outro dos fariseus, que estava i tirando e lançando pedras contra el, filhou ũu pao que achou i que era de ũu tintoreiro e deu com el em na cabeça ao apostolo, de guisa tal que lhe quebrantou a cabeça e foe logo morto (ibidem, p. 99)

tan mal foi o abade sanhudo contra este santo Libertino que meteu a el mão e, porque non achou vara nen paao con que lhi desse, tomou as talhoos que tiinha ant o leito e tan gram ferida lhi deu con elas na cabeça e no rostro (SILVA 1971: 9).

Dado o contexto de composição destas cantigas, é especialmente relevante uma bula de Gregório IX, datada de 14 de junho de 1233, em que o próprio rei Sancho II é mostrado a agredir clérigos com um pau:

68 Lapa (1970a: 336). Instrumento semelhante (espeto de assar leitões) é igualmente referido na cantiga Don Pedro est cunhado d'el-rei, de Fernão Rodrigues Redondo. Neste caso, segundo informação da própria rubrica atributiva, é D. Pedro de Aragão, filho de Pedro III de Aragão, que fere, com esta forma de pau, um seu mordomo (CORREIA 2003). 
Portugalie Regis illustris fuit nobis humiliter supplicatum ut cum ipse, in exercitu uel alibi constitutus, non suadente diabolo sed ordinandi aciem uel declinande pressure necessitate cogente, uirga interdum impulerit quosdam clericos siue manu, impendi sibi absolutionis beneficium faceremus $^{69}$.

Há ainda duas ocorrências em que a palavra refere instrumentos de apoio para pessoas com insuficiências físicas:

Ante a porta jazia ũu homem tolheito, e siia pidindo esmola aos que passavam, e quando avia dandar sofria-se en dous paaos (PÍEL 1988: 425).

E dom Gonçalo Gustiuz tantas lagrimas lançava cada / dya per sus olhos que nõ podya ja bem veer; e andava com hũu paao na mãao (CINTRA 1984, vol. 3, p. 152).

Deverá tratar-se de instrumento de apoio semelhante a este último, o que é referido na cantiga Sabedes vós: mestre Nicolao, de Pero Garcia d'Ambroa: «e faz o ceg'adestrar pelo pao» (ALVAR 1986: 72).

Poderíamos pensar que o pau a que se alude na cantiga estaria relacionado, no exemplo acima, com eventuais défices de visão de «Don Estevan». Mas o comentário sobre o «pao», que o autor atribuiu ao vilão, não permite esta possibilidade de leitura: «un gran pao que achou non sei u». Se o vilão não sabe onde «Don Estevan» encontrou o «pao» com que o agride, não deveria associá-lo a instrumento que lhe estivesse habitualmente próximo, como estaria no caso de se tratar de apoio para homem com dificuldades visuais. Voltaremos a esta declaração do «vilão».

Já o termo «baston» não ocorre em nenhuma outra cantiga profana e também não consegui encontrá-lo na prosa medieval. Verificam-se, no entanto, algumas ocorrências nas cantigas de Santa Maria, sempre como instrumento de agressão (METTMANN 1986-1989, vol. 1, p. 137, 174, 268), exceto na cantiga de Santa Maria 49, onde o «baston» tem função muito diferente:

E en aquel gran lum' enton

viron hũa mui bela

moller de corp'e de faiçon,

69 Costa (1963: 204). «É um dos raros momentos em que lhe podemos captar traços individualizantes: as agressões foram praticadas por ele mesmo e não a seu mando, com a mão e com um bastão» (FERNANDES 2010: 256). 
e ben come donzela

lles pareceu; e pero non

siia en sela,

mas tĩa na mãun baston

que resprandecia (ibidem, p. 178)

Confirma este exemplo que a palavra «baston» poderia referir, além de uma vara que servisse para agredir, também um instrumento simbolicamente investido, um distintivo prolongamento do poder de quem o empunha, neste caso, a virgem Maria.

O termo «cabeçon» corresponde a uma parte de vestuário que é agarrada com o objetivo de segurar e agredir quem o enverga. Encontra-se na prosa associado a episódios de violência parecidos com o que é descrito na cantiga em análise. Não parece tratar-se de parte de vestuário específico de classe ou ocupação, embora os exemplos que se seguem excluam serviçais.

E el rei, quando esto vyo, deu grandes vozes que nõ pellejassem ante elle. E foi mui sanhudo contra Pedro Vermuiz e tomouho pello cabeçõ e pediolhe a espada. E o Cide cuidou que o queria ferir cõ ella e disselhe: (CINTRA 1990: 152).

E, como chegou a elle, travoulhe per o cabeçõ e tirou a espada e quiseralhe cortar a cabeça. Mas IIII cavaleiros que chegarõ com elle lhe disserom:

- Oo Senhor, por Deus e por mercee, non matees o cardeal, ca dirã en Roma que sooes herege (ibidem, p. 228).

E desy descalçou o arcipreste os panos meores e abraçouha. / E, cuydando fazer sua võotade, lançou os braços em ella. E ella filhouo cõ ambas as mãaos per o cabeç̃̃ e disse: [...] (CINTRA 1984, vol. 3, p. 76).

O termo «vilão» exige igualmente ponderação. Os dicionários e glossários apontam para um significado bastante estreito, colocando o «vilão» no extremo inferior da hierarquia social, ou seja, junto dos camponeses: $\ll$ vilan $=$ vilão, homem de inferior categoria»; (LAPA 1970a: 110) «villano, hombre bajo, vil, rústico, campesino $\gg^{70}$.

Um levantamento de ocorrências da palavra poderá, no entanto, obrigar a repensar a simplicidade da glosa. Devemos talvez começar por distinguir o uso do substantivo (vilão) do uso do adjetivo (vilão). O significado do primeiro é claramente social, o do segundo creio ter sofrido a influência do adje-

Lorenzo (1977: 1317). Também Corominas e Pascual (2006-2007, vol. 5, p. 819). 
tivo «vil» e ter sentido mais moral, ou seja, assumindo o significado de malvado. Comecemos pelo adjetivo.

$\mathrm{Na}$ Demanda do Santo Graal, onde o adjetivo é especialmente abundante, encontram-se diversas ocorrências bastante inequívocas quanto ao sentido moral:

Dom Galvam, por[que] sodes tam vilão e tam envejoso?; (PÍEL 1988: 389)

E ella cuidava que, pois ella [se] deitar apar delle, que el conprisse seu coraçom, e em nenhũa guisa nom cuidava, pois que ella era atam fremosa e de tam gram guisa, que el tam vilão fosse que nom conprisse sua vontade (ibidem, p. 73).

[... se Deus majude, nom a no mundo tam vilã $[\mathbf{o}]$ cavaleiro sabendo sa bondade e sa cavalaria como a eu sei que ouvesse vontade de o matar, se nom fosse mais desleal ca outro cavaleiro (ibidem, p. 389).

Se assim entendermos o adjetivo na cantiga $O$ infançon ouv'atal, de Lopo Lias, o texto entender-se-á melhor ( $\ll$ Ao infançon vilan, afamado come can ${ }^{71}$ ), até porque, como veremos, no que respeita ao substantivo «vilão», a oposição a infanção é total. De acordo com esta ordem de ideias, também a adjetivação de «coteife» terá sentido moral, não devendo o conjunto «coteife vilão» ser visto como uma sequência de sinónimos: «e dar-vos-ei en ajuda muito coteife vilão» (Don Rodrigo, moordomo, que ben pôs el-rei à mesa de Alfonso $\mathrm{X})^{72}$. A adjetivação do termo «palavras» pelo feminino «vilããs» parece ter igualmente este sentido: «Outrossy, senhor, mandade que nem hũu nõ se atreva de me dizer pallavra villãa / nẽ desaguisada per que despois venhamos ao pior» (CINTRA 1990: 144); «disse ao santo homen per sas palavras vilããs que aquela oraçon que fezera per tres dias e per noites mais o fezera por louvamĩha dos homẽẽs ca por galardon que de Deus atendesse» (sILva 1971: 112).

Quanto ao uso do substantivo, ele está quase sempre socialmente empenhado. Vejamos que informação suplementar se pode recolher das diversas ocorrências do termo na lírica e na prosa.

Na cantiga de Pero da Ponte De [Don] Fernan Diaz Estaturaõ, o termo «vilão» ocorre em oposição a «fidalgo» («nen nunc'amou molher nen seu solaz, nen desamou fidalgo nen vilão $\gg^{73}$ ). Também na cantiga Pero d'Ambroa,

\footnotetext{
71 Lapa (1970a: 399).

72 Ferreiro (2016-).

73 Juarez Blanquer (1988: 252).
} 
averedes pesar, de Pero Mafaldo, se vislumbra a mesma oposição («polo vilão, que vilão é, / pon ora assi en seu degred'el-rei / que se non chame fidalgo per ren, / se non, os dentes lhi quiten por én ${ }^{74}$ ), embora a proibição a que se faz alusão torne plausível a prática proibida. Na verdade, se considerarmos um adjetivo a segunda ocorrência de «vilão», a proibição apenas se aplicaria a certo tipo de vilões.

A tenção entre Juião Bolseiro e Joam Soares Coelho, a propósito da Ama, associa o jogral Juião Bolseiro à condição de vilão e, também neste texto, a encontramos em oposição à fidalguia. Mas não será sem importância a adjetivação do substantivo que poderá introduzir alguma categorização da condição de vilão: «Juião, tu deves entender / que o mal vilan non pode saber / de fazenda de boa dona nada» (CORREIA 2017: 48-49, 80-82).

$\mathrm{Na}$ cantiga de D. Dinis, De Joan Bol'and'eu maravilhado, refere-se um vilão na dependência de um senhor, Joan Bolo, frequentador da corte de D. Dinis («que tragia rocin bel'e loução, / e disse-m’ora aqui un seu vilão / que o avia por mua cambiado ${ }^{75}$ ), no espaço que etimologicamente se relaciona com o termo «vilão»: «que non sei oj’ome que a tirasse fora da vila, pero o provasse» (GONÇALVES 1991: 53). A mesma situação de dependência encontramos associada à condição de vilão na cantiga Fernan Gil and'aqui ameaçado, de Afons'Eanes do Cotom ( «ca é filho dun vilão de seu padre / e demais foi criado de sa madre $\left.{ }^{76}\right)$. Igual associação se verifica em Lourenço Bouçon, o vosso vilão, de Joam Velho de Pedrogais ( «Lourenço Bouçon, o vosso vilão, que sempre vosco soedes trager, / é gran ladron $>{ }^{77}$ ). Mas, neste caso, a rubrica que precede a cantiga contém um importante esclarecimento: «Esta cantiga de cima foi feita a um cavaleiro que fora vilão $\gg$. De acordo com este esclarecimento, a condição de cavaleiro e de vilão não coincidiam, sendo a segunda apenas indicativa de origem para o cavaleiro que a tivesse. Sabemos, no entanto, que a condição de cavaleiro-vilão existia: eram os que não tendo nascido nobres assumiam a função de cavaleiros. Encontramos de novo a condição de vilão associada a dependência, na tenção Muito te vejo, Lourenço, queixar, entre Joam Garcia de Guilhade e Lourenço ( «e logo o mandarei / pagar a [un] gran vilão que ei ${ }^{78}$ ) e igualmente na tenção - Ai, Paai Soárez, venho-vos rogar (LAPA 1970a:448), entre Martim Soares e Pai Soares de Taveirós.

\footnotetext{
74 Eirín Garcia e Ferreiro (2014: 99).

75 Gonçalves (1991: 53).

76 Marcenaro (2015: 58).

77 Calderón Calderón (1998: 128).

78 Lapa (1970a: 336).
} 
Na cantiga Joan Garcia tal se foi loar, de Joam Soares Coelho, é tratada uma oposição entre «os melhores trobadores» (que deveriam fazer trovas às «mais altas donas e melhores») e o «coteife» («e o coteife que for trobador / trobe, mais cham'a coteifa "senhor" $\gg)$. A este arrazoado acrescenta-se na finda: $\ll$ E o vilão que trobar souber / que trob'e chame "senhor" sa molher / e averá cada un o seu dereito» (CORREIA 2017: 57-58). Se «vilão» e «coteife» fossem sinónimos, teríamos de ver nesta finda uma simples repetição do que acabou de ser dito na estrofe imediatamente anterior. Se não se tratar exatamente de uma repetição, teremos de ver em «vilão» uma condição com diferenças de significado relativamente a «coteife».

$\mathrm{Na}$ tenção entre Juião Bolseiro e Mem Rodrigues Tenoiro, este declara a intenção de desencorajar qualquer «vilão» de o desafiar para outras tenções ( «que nunca vilão haja sabor / d'outra tençon comego começar ${ }^{79}$ ), donde se depreende que associe Juião Bolseiro, jogral, a esta condição, tal como Joam Soares Coelho, em tenção, tinha feito. A mesma condição é associada a Lourenço («Lourenç'enas terras u eu andei, / non vi vilão tan mal departir»), na tenção Rodrigu'Eanes, queria saber (LAPA 1970a: 408), entre o jogral e Rodrigo Anes d'Alvares. Mas «departir» é atividade de composição, que exigiria conhecimentos específicos, mesmo que mínimos.

As ocorrências do termo na prosa medieval poderão ajudar a determinar facetas de sentido. Na Demanda do Santo Graal, há um episódio especialmente esclarecedor. Uma mulher pede a Persival que ordene cavaleiro um donzel que achara abandonado na floresta, quando bebé, e que criara até à idade de 15 anos. O cavaleiro responde-lhe:

\begin{abstract}
«Dona» disse Persival, «vos dezedes a vosso prazer, mas certamente, pois que vos nada nom sabedes de sua linhagem, nom tenho rezam por que o quisesse fazer cavalleiro, ca hei medo de seer de linhagem de vilãos, e rogo-vos que vos nom pese dello» (PÍEL 1988: 168).
\end{abstract}

Igualmente esclarecedor são os seguintes passos da Crónica geral de Espanha, onde vemos coincidirem os estatutos de «vilão»e «cidadão»; e dos Diálogos de São Gregório:

E hũu cidadãao que estava acerca del rey disse: $[\ldots]$ Certo os que fogem, nós os villãaos somos, ca os fidalgos non. $E$ este cidadãao era natural de Medina del Campo e avya nome Andre Bocas e, por esta pallavra que disse, 
o apedraron depois os villãaos de Medina. E matou el rey todollos que soube que o apedrarõ (cintra 1990: 332).

Enton começaron a correr pera o santo homen, homens e molheres filhos d'algo e vilããos e cada hũũ se trabalhava pera levar o santo homen pera sa casa (SILVA 1971: 112).

Embora fique claro, por estes exemplos, que a condição do vilão se opõe pelo nascimento à dos fidalgos ${ }^{80}$, para os quais a cavalaria estaria idealmente reservada, não se lhes considerava vedado nem o acesso às letras nem o acesso a responsabilidades administrativas, nem à riqueza e ao poder, nem mesmo ao casamento com elementos da nobreza, conforme se verifica nos seguintes passos da historiografia medieval:

Ho castello de Mõte Mayor e o de Gaya, tiinhaos Gonçalo Perez Ribeiro que fezera por elles menagem a el rey dõ Denis, cõ muy grande contya que avya cõ cada hũu delles. E elle deuos a teer a dous villãaos a que dava por o ano senhos moyos de milho. E, quando o iffante chegou a Monte Mayor, nõ achou senõ aquelle villãao. E o iffante matouo logo e tomou o castello. E foysse logo a Gaya e o villãao que tiinha o castello deulho. E, despois que o iffante ouve tomadas estas cidades e castellos, foy sobre o castello da Feira que he ẽ terra de Sancta Marya e tiinhao hũu cavalleiro que avya nome Gonçalo Roiz de Maçada. E, logo que hy chegou, entregoulhe o castello, por que elle lhe mandara dizer que veesse hy e que lho entregaria. E assy cobrou o iffante o castello e elle ficou por treedor (CINTRA 1990: 253).

E, logo en esse verãao, tornou o iffante a Lixboa por veer seu padre e lhe mover outras cousas affora aquello que antre elles era posto. E esto per cõselho do villãao vogado que ante dissemos e doutros que andavam fazendo estas maneiras (ibidem, p. 256).

Esta dona Costança Martĩiz Barreta foi casada com Remond'Ianes, filho de dom Joham Perez Bochardo, e fez em ela dona Beatriz Martĩiz, que foi casada com Gomez Lourenço de Beja, vogado e vilão (мATTOso 1980, vol. II/1, p. 319)

P. Merêa (1929: 449-450) atribui o significado ao termo que se depreende do seguinte passo: «Em contraposição à classe nobre, as outras pessoas, qualquer que fôsse a sua situação ou ocupação, abrangiam-se na denominação comum de vilãs, e a sua característica mais geral era a sujeição a prestações a encargos da mais diversa natureza e proveniência. Havia porém indivíduos de classe vilã, principalmente nos grémios municipais, que eram obrigados, em razão dos seus haveres, a manter cavalo e armas advindo-lhes de aí privilégios mais ao menos extensos. Eram os chamados cavaleiros-vilãos $\gg$. Especificamente sobre os cavaleiros-vilãos veja-se o capítulo «Les chevaliers-vilais: élite paysanne ou noblesse inferieure?» em Durand (1982:532-558). 
Esta dona Orraca Fernandez foi casada em Santarem com ũu cidadão que havia nome Domingos Johanes Fura Covas, que era vilão rico e poderoso, e fez em ela (ibidem, p. 478).

foi casado com dona Marquesa Pirez, filha de Pascoal Pirez, um vilão aragoês que morava em Lixboa, e de Elvira Martĩiz, filha de Martim Micha de Lixboa (ibidem, p. 402).

O substantivo «vilão» designará, portanto, pessoa cujo nascimento era alheio à nobreza, mas que nem por isso pertenceria necessariamente ao grupo dos camponeses ou às camadas mais indefesas da sociedade. $\mathrm{O}$ grupo social dos vilãos, a que pertenceriam os jograis, determinado pelo nascimento não nobre, conservaria de resto alguma diversidade quanto a outras caraterísticas. $\mathrm{O}$ termo parece mesmo ter guardado a ligação ao espaço urbano que a etimologia determina e, no período em que as cantigas em estudo foram compostas, poderá refletir a importância crescente das oligarquias urbanas que então precisamente se verificava. Idealmente, a cavalaria ser-lhe-ia alheia; na prática, a cavalaria era uma nova condição daquele que, tendo nascido vilão, lhe tinha acesso. Na oposição entre fidalgo e vilão, que observamos nos textos, não deveremos, pois, ver extremos de uma hierarquia social, mas diferentes condições determinadas pelo nascimento a que eram associadas diferentes funções em relação às armas, e diferentes privilégios.

Deixei para o fim, uma ocorrência do termo «vilão» que, pelo contexto, se aproxima da cantiga em estudo. Poderemos nele encontrar algum esclarecimento sobre o que pode significar viver o vilão com «Don Estevan», bem como sobre o sentido da revolta de que a cantiga se ocupa:

Este Gran $[c]$ iam, quando houve a terra livre dos maos homẽes, creceo-lhe grande argulho e houve grande soberba, e era homem de maa vida, e viltava os homẽes bõos da terra, os ricos e os pobres, e era de maa conteença. E acordarom-se os vilãos sobr'ele ũa noite que ele jazia em seu leito, que nom podiam viver com ele, tanto era mao homem, e matarom-no. E os Romãos que erom com el nas legiões tornarom-se a Roma, e ficou a terra despobrada de cavaleiros (MATTOSO 1980, vol. II/1, p. 86).

Graciam é, nesta história, um vassalo do rei Maximiam, que se encontra em Roma. Enviado pelo Rei para libertar as terras de Inglaterra de dois reis pagãos que a tinham dominada, consegue-o. A vitória torna-o arrogante, orgulhoso; maltratando por isso todos os que o rodeavam, fosse qual fosse a condição. Os «vilãos» que com ele «viviam» concordaram por isto que a vida com tal pessoa já não era suportável e uma noite matam-no enquanto dorme. Os 
soldados, cuja condição é a que se opõe à dos vilãos, regressam então a Roma para junto do rei Maximiam.

Voltando à cantiga em análise é importante notar que o sujeito refere a relação entre «Don Estevan» e o vilão recorrendo à fórmula habitualmente usada para aludir às relações de vassalagem («un seu om'»), o que aponta para uma relação de direitos e deveres, mais do que para uma relação com serviçal. Não é momento único, aliás. A mesma formulação volta a ocorrer quando «Don Estevan» se defende invocando uma certa inversão do serviço: «mais era eu seu ca era ele meu», onde deverá ler-se que, na ótica de «Don Estevan», o vilão era mais servido por ele do que o contrário. Apanhado em flagrante delito de agressão, pede que o impeçam de agredir, declara-se humilde servidor do seu servidor ( «mais era eu seu ca era el meu») e deixa implícita uma justificação para a agressão: o facto de o vilão se ter vinculado a ele por interesse («peró xi m'el queria» $=$ por isso me queria ele [para seu senhor]).

Não será, no entanto, exatamente uma relação de vassalagem, uma vez que esta é própria de militares, e tanto o vilão quanto «Don Estevan» estão fora desta ordem. Mas é, como se diz na cantiga, um relacionamento «jurado». Recordo, a propósito, um passo da Primeira partida sobre a forma de honrar os prelados através do tratamento:

E a onrra que lhy deuedes a ffazer per parauoas he que os chamã senhores polos logares onrrados que tẽẽ dos apostolos como dito he e por que ssom guardadores das almas (FERREIRA 1980: 257-258).

A questão da ordem na marcha é levantada pelas três vozes da cantiga: encontramo-la na descrição do quadro de agressão feita pelo sujeito ( $\ll$ Don Estevan achei $[\ldots]$ depos un seu om'ir $[\ldots]$ / e sol non lhi pôd'un passo fogir / aquel seu ome depos que elia $»$ ), na descrição feita por «Don Estevan» («muit' andava mais empos el eu / ca el pos mi») e na descrição feita pelo vilão ( «sempre a gran coita deante lh'andei / e el sempre deante me metia $\gg)^{81}$. Apenas o tempo distingue estas referências: no primeiro caso, descreve-se o que é observado num momento de agressão; no segundo caso, indica-se, mediante pretérito imperfeito, um tempo passado e prolongado de vida conjunta, mas ainda assim indeterminado; no terceiro caso, é considerado todo o tempo de vínculo entre os dois ( «Don Estevan» e o vilão), desde o juramento que instituiu o serviço, até ao presente em que o sujeito surpreende o ato de agressão. Mas o quadro descrito é 
sempre o mesmo: «Don Estevan» segue o vilão; para o servir, segundo «Don Estevan»; para o agredir, segundo o vilão e o sujeito.

Em qualquer caso, a questão da ordem na marcha relaciona-se com a do serviço e, naturalmente, com o juramento que o institui, uma vez que, como poderemos ver nos exemplos que se seguem, quem serve segue, na marcha, quem é servido. A ordem na marcha é, portanto, manifestação de relacionamento e hierarquia ${ }^{82}$.

E, hyndo os reis ambos fallando, hyã empos elles dous cavalleiros mouros que eram grandes fidalgos. [...]E ẽpos estes hya hũu privado del rei que ouvya todo o que elles diziã (CINTRA 1984, vol. 3, p. 372).

E, quando enlaçou a capellina, cayulhe a coifa en terra e nõ a vyo. E endereçou per seu caminho e seu scudeiro empos ele. [...]E, quãdo desenlaçou a capellina, non achou a coifa e preguntou por ella. E o scudeiro disse que lha non dera. E, depois que foy certo que lhe caera, tomou outra vez suas armas e disselhe que o seguisse e que tevesse mentes polla coifa onde lhe caera (CINTRA 1990: 451).

Na situação retratada nesta cantiga, a partir de vários ângulos, reconhecemos a dependência de dependentes que já tinha sido apontada na cantiga Don Estevan que lhi non gradecedes, de Joam Soares Coelho. «Don Estevan» depende daqueles que o servem e esta dependência obriga-o ao uso da força para os obrigar a não se afastarem um só dia («ca me non poss'un dia del partir») nem se afastarem um centímetro ( «sol que lh'ome desvia»). O vilão justifica a dependência e as agressões com a mesma palavra, que, ao mesmo tempo, identifica o agressor: «torto» (zarolho ou parco de entendimento, injusto e Torto). «Don Estevan» depende do vilão, porque, sendo incapaz de bom entendimento (torto: zarolho, isto é, incapaz de entendimento), precisa de quem o ajude; ao enfurecer-se e agredir aquando do mais pequeno afastamento do vilão, é injusto (torto) e, sendo Torto alcunha do arcebispo Estêvão Soares, é também outra forma de identificar Joam Viegas a quem, por ironia, os trovadores, neste conjunto de cantigas, chamam «Don Estevan».

82 Em caso de cortejos solenes, as precedências e sequências têm uma configuração mais complexa, mas o princípio é mesmo: «E, quando el rei chegou a elles, era preto da villa quanto mea legoa. E elles viinhã em esta guisa: os $\mathrm{III}^{\mathrm{c}}$ cavallos viinhã diante cõ suas espadas aos arçõoes. E estes tragiãnos os donzees pellas redeas. E, empos elles, viinham os pajes de todollos cavalleiros, ẽ cima de seus cavallos, com lanças ẽnas mãaos. E, despois destes, viinham dom Alvaro Fernandez e Pedro Vermuiz, ambos a par. E, despos elles, toda sua companha. E, cõ esto, cem pares d'armas alçadas.» (CINTRA 1990: 110). 
«- Mui gran mal fazedes en consentir / a est'ome tort'o que mi fazia»: eis o núcleo da cantiga, em torno do qual o autor dispõe a mesma cómica cena de agressão, primeiro descrita pelo sujeito e depois divergentemente interpretada pelas duas partes envolvidas. «Don Estevan», surpreendido em vergonhosa agressão, sobretudo para um clérigo, ainda mais um Arcebispo, pede que o impeçam de agredir, o que é outra forma de pedir ajuda para controlar a fúria. Justifica-se com a humildade com que serviu quem devia servi-lo e, nesta declaração, dá provas da tola candura de que é acusado noutras cantigas, mais exatamente Don Estevan que Thi non gradecedes, de Joam Soares Coelho, e na cantiga de Queimado que nesta se inspira, Don Estevan, en grand'entençon. Em todo o caso, vemo-lo seguir humildemente dependente na marcha aquele que deveria segui-lo. E concluir que, por esta humildade e serviço, o vilão se interessava por ele («peró xi m’el queria»), deixando implícita uma acusação de deslealdade ao jurado vilão. Diante da concessão dos interlocutores de «Don Estevan» ( «Mui gran mal fazedes en consentir»), o vilão desmente «Don Estevão» mostrando-se seguido por ele, sim, mas sob ameaça de um pau ou de um bastão, instrumento de agressão onde podemos ver uma alusão ao báculo do Arcebispo. Sobretudo se atentarmos na observação «que achou non sei u» e quisermos ver nela uma crítica que já encontrámos também na já referida cantiga Don Estevan que thi non gradecedes de Joam Soares Coelho. Ou seja, uma crítica à eleição de pessoa inqualificada para a posição de arcebispo de Braga, necessariamente frequentador da corte.

A sátira, neste texto, orienta-se portanto não só, e talvez não tanto, para as agressões de «Don Estevan», mas para a inabilidade político-diplomática que $o$ leva a, querendo salvar a face quando é surpreendido em flagrante delito de agressão, usar um argumento que o mostra humilhado aos que o servem, dependente de dependentes e incapaz de os reter a não ser pela força. Embora a tentativa de reinterpretação da ordem na marcha (da agressão) como humilde serviço pareça surtir certo efeito, além de humilhante, corresponde a uma negação de evidências tão infantil quanto infantil era a negação da «cegueira» de que o acusava Roi Queimado na cantiga Don Estevan, en grand'entençon, onde esta figura é também mostrada a defender-se de acusações com a mesma inábil candura. $\mathrm{Na}$ verdade, tanto Queimado quanto Tenoiro procuram deixar claro que «Don Estevan» é tão incapaz a argumentar em defesa própria que o retrato resultante da defesa é ainda pior do que se a não tivesse empreendido.

Tenho dado ao vocabulário e expressões nucleares do texto - «un passo fogir», «mais era eu seu ca era el meu», «muit'andava mais empos el eu / ca el pos mi « «xi m'el queria», «deante lh'andei», «deante me metia», «un dia del partir», «sol que lh'ome desvia», e mesmo, «co el mais guarir» - uma interpretação essencialmente literal. Devemos considerar, no entanto, a natureza política 
do conjunto satírico a que esta cantiga pertence, assim como estarem nela representados três grupos sociais em frequente e alternados conflito e aliança, mais ou menos violento um, mais ou menos instrumentalizada outra, especialmente no período em que estas cantigas foram compostas: a nobreza do autor, o clero do visado e os vilões a que pertence o agredido. Assim como devemos considerar o espaço urbano que serve de cenário a este conflito ${ }^{83}$. Não é difícil, portanto, encontrar no vocabulário e expressões indicados um segundo sentido que possa dar à cantiga uma interpretação metafórica, até considerando os frequentes e conhecidos conflitos entre os bispos e os cidadãos dos concelhos. Ser de alguém e andar atrás de alguém pode também significar defender os interesses de alguém, exprimir as opiniões de outrem como próprias; assim como desviar-se de alguém e partir pode significar deixar de o fazer.

83 Veja-se um exemplo representativo disto mesmo: «No caso do Porto, contudo, o rei não se ficaria por aqui: durante cinco longos meses o seu porteiro, acolitado por dois servidores e por vários "burgensis", isto é, cidadãos, do Porto, sempre dispostos a seguir o rei contra o bispo, num conflito que haveria de se prolongar por mais de um século, mantêm Martinho Rodrigues enclausurado com o seu deão no paço episcopal, de onde só sairá, numa fuga nocturna com destino a Roma, a tempo de evitar a composição que Sancho, O Velho, o queria compelir a subscrever. [... ] Mais uma vez a violência toma um rumo patrimonial atentatória da imunidade eclesiástica, em que os funcionários régios e os cidadãos se mancomunam contra o senhor da cidade, o bispo, senhor que o é porque o rei o fez.» (FERNANDES 2010: 39). 


\section{Airas Peres Vuitorom}

I 1 Don Estevan, tan de mal talan ${ }^{84}$ sodes que non podedes de peior que ja por ome que vos faça amor sol non catades, tal preço vos dan.

5 E sêrvia-vos ome quanto puder se vos desvia quan pouco xiquer ides log' ome trager come can

II e tan mal dia vosco tant' afan e tanta coit'á convosc'a levar.

10 Pois non avedes por om'a catar mal serviço faz om'en vós de pran ca se avede-la besta mester se vo-la ome toste non trouxer queredes ome trager come can.

III 15 E, Don Estevan, pois sodes tan sanhudo que non catades por quen vos faz serviço pois vos sanha ven, os que vos serven non vos serviran ca, se vos sanha, como sol, preser non cataredes ome nen molher que non querades trager come can.

O estudo de algum vocabulário desta cantiga poderá, como aconteceu anteriormente, trazer esclarecimentos importantes. Começaremos por um verbo que constitui um ponto de ligação entre esta cantiga de Airas Peres Vuitorom e a de Tenoiro, anteriormente analisada, e que valerá a pena esclarecer: «desviar». Segundo ambas as cantigas, o ato assim referido não é tolerado por «Don Estevan» aos que o servem. Tenoiro fecha assim a cantiga: «e pois s'assanha non cata per u / feira con el, sol que lh’ome desvia». Já Vuitorom recorre ao verbo na primeira estrofe da cantiga, para indicar exatamente o mesmo, ou seja, o que espoleta

84 B1474/V1085 Aparato crítico - 1. estauam v; 6. pouroxi в 12. anedela в, 13. nola в. - As diferenças entre esta edição e a de R. Lapa (1970a: 126) são de reduzida importância: diferente separação das palavras, no verso 9; diferente pontuação e consequente entendimento dos períodos no verso 10; diferente desenvolvimento da abreviatura na forma do verbo «querer» que se encontra no último verso. As edições posteriores à de R. Lapa adotam-na sem alterações significativas. 
a fúria de «Don Estevan», apesar do dedicado serviço dos seus homens: «E sêrvia-vos ome quanto puder / se vos desvia quan pouco xiquer / ides log' ome trager come can».

O verbo «desviar» não é comum na Lírica Galego-Portuguesa, ocorrendo apenas outra vez na famosa cantiga de amigo de D. Dinis (Levantou-s'a velida,) em que se refere uma menina e as camisas lavadas no «alto», onde «o vento lhas desvia» (FERREIRO 2016-). O verbo parece ter portanto, na lírica, o sentido concreto de «afastar fisicamente». A prosa oferece, porém, alguns exemplos de uso metafórico:

Este rey Recaredo foy muy nobre homen e de nobres condiçõoes e de sanctos costumes e muy desvyado da grande crueldade de seu padre (CINTRA 1984, vol. 2, p. 200).

Quando a condessa vyo o consselho de dom Symon dava [sic], tã desviado do que ella queria, tornousse a dom Symon e disselhe: (ibidem, p. 320)

Considerando as acusações de dependência de dependentes, que encontrámos noutras cantigas, a atribuição do sentido concreto ao verbo «desviar», que lhe atribuí na análise da cantiga anterior, faz sentido («e pois s'assanha non cata per u / feira con el, sol que lh’ome desvia »). Continua a subjazer a sátira a um homem incapaz de lidar com os ambientes para onde foi elevado e, portanto, dependente dos que o servem, aos quais não permite que se afastem minimamente. Mas Vuitorom não insiste neste ângulo nem sequer o deixa muito exposto, até porque, como vimos anteriormente, ele implica uma sátira ao próprio rei Sancho II - a de ter influenciado, se não determinado, a escolha de Joam Viegas para o arcebispado de Braga -, que a Vuitorom, partidário da posição real, não interessava. É certo que a ligação anteriormente estabelecida entre esta cantiga e Don Estevan fez sa partiçon, de Coelho, aponta para uma datação posterior à morte de Sancho II, o que atenuaria a importância de qualquer alusão às responsabilidades do Rei na eleição de Joam Viegas. Mas restaria a necessidade de alguma coerência. A datação também jutificaria as assinaláveis diferenças de abordagem entre esta cantiga e a anteriormente estudada de Vuitorom.

Note-se o esclarecimento dado no texto em análise sobre a natureza do «desvio», que reforça a interpretação feita: «Don Estevan» não tolera o referido «desvio», mesmo que seja muito servido, tanto quanto possa quem o serve: «sêrvia-vos ome quanto puder / se vos desvia quan pouco xiquer / ides log'ome trager come can». $\mathrm{O}$ «desvio» que enfurece «Don Estevan» não corresponderá, portanto, a nenhuma falha no serviço, que aqui se apresenta como imacu- 
lado e completo. Não se trata de falta de lealdade, mas de simples afastamento, que o deixa desapoiado.

O conjunto «mal talan» ou «mal talante» ocorre em mais três cantigas profanas (Muigran temp'a, par Deus que eu non vi, de um anónimo (FERREIRo 2016-); Muytus a que Deus quis dar muy bon sen, de Pero Goterres (DonAti 1979: 81-82); e Tant'é Melion pecador, de D. Dinis (LAPA 1970a: 147) e também em algumas cantigas de Santa Maria, embora, neste corpus, seja muito mais frequente o conjunto «bon talan». «Mal talan» é usado, tanto na lírica quanto na prosa, para indicar uma inclinação negativa de caráter conducente a ações normalmente violentas. Esta inclinação pode ser considerada permanente, caso em que o verbo «ser» é mais frequentemente chamado a introduzir o conjunto; ou momentânea, circunstancial, caso em que outros verbos introduzem a expressão. É significativo que «mal talan» se associe frequentemente a vocábulos da família de «sanha» como poderemos ver nos passos que se seguem.

E elle assi jazendo vio vir contra si Boorz, seu irmão. E tanto que o conhoceo, logo lhe lenbrou do perigoo em que o leixara e começou a morrer de sanha e de mal talante. E ergeo-se contra elle, mas nom para salua-lo mas para fazer-lhe mal e pesar, se podesse (PÍEL 1988: 120).

«Senhor», disse Blioberis, «verdade é, mais pero é custume que, se ũu cavaleiro vee i mui bõos justarem-se por sanha e por maa talant aa batalha, se os non conhece e ha sabor de os preguntar polla bondade que em elles vee $e$ os preguntar por sua fazenda, nom lho teerem a vilania (ibidem, p. 260).

E aquel que o havia a escabeçar deu-lhe tres golpes com a espada, mais, pero, nom the pôde fazer nem ũu mal. E, quando vio que lhe nom podia nem ũu mal fazer, foe ende muito sanhudo e com mui mao talante (CEPEDA 1989, vol. 1, p. 334).

E o alcaide, que era mui forte e mui sanhudo e de mao talam, mandou meter com el ũu leom pardo mui bravo. E o leom pardo leixou Santo Andre e sobio pera u stava o alcaide e filhou aa garganta u seu filho que stava com el e matou-o (ibidem, vol. 2, p. 167).

Un alcayd'era na vila, / de mal talan e sannudo, / soberv'e cobiiçoso, que per el nyun dereyto / nunca ben era juygado; / demais era orgulloso e cobiiçava muito / por achar en que travasse a quem quer, ou pobr'ou rico, / per que algo del levasse (METTMANN 1986-1989, vol. 3, p. 249-250). 
Na cantiga em estudo, a alusão ao «mal talan» de «Don Estevan» parece implicar um traço de caráter permanente, que o leva a reagir mal, sempre que se encontra na circunstância de ser contrariado, mesmo que levemente, ou de não ser logo obedecido ( «se vos [ome] desvia quan pouco xiquer»; «ca se avede-la besta mester / se vo-la ome toste non trouxer / queredes ome trager come can»). Tal como em vários outros textos, a expressão «mal talan» vem, neste, associada ao adjetivo «sanhudo» e ao substantivo «sanha» para compor o retrato de um caráter irascível.

A expressão «fazer amor» com sentido jurídico-político tem afinidades semânticas com vocabulário («amar», «desamor» etc.) que ocorre também na outra cantiga dedicada por Vuitorom a Don Estevan (Don Estevan diz que desamor), e foi a propósito dela já estudada. Trata-se ali da expressão de «amor» do Rei ou do Conde a «Don Estevan», tratando-se aqui da expressão de «amor» a «Don Estevan» por «ome» que o tenha beneficiado, alusão que deverá envolver o Rei, tanto mais que se segue a acusação de falta de retribuição.

Associada à concessão de bens, por vezes como forma de manifestação de apreço, encontramos a expressão em documentação que envolve doações e que já invoquei a propósito da cantiga Don Estevan diz que desamor, de Airas Peres Vuitorom. Recordo-a aqui também.

E este amor e este quitamento que vos fazemos de todas las cosas sobredichas fiziemos lo por muchos dobdos de bien que son entre nos e vos e vostra mugier e vostros fijos e por la ayuda que nos feziestes en nostra guerra por mar e por terra (VENTURA e OLIVEIRA 2006-2011: 435).

Et mando quod donna Constancia teneat in vita sua illam hereditatem quam modo ibi habet sicut eam tenebat in diebus mariti sui et post mortem suam ipsa hereditas dividatur inter pauperes Ulixbone qui non habuerint aliam hereditatem in qua laborent sicut avus meus et pater meus illam dividere mandaverunt. Et istum amorem facio donne Constancie pro servitio quod maritus suus mihi fecit et quia ipsa est domina cum qua habeo debitum (ibidem, p. 413).

Do vobis et concedo ipsum casale cum omni iure suo et pro amore quod michi fecistis et pro una buzeta de tiriaga quam michi dedistis apreciata in $X .{ }^{a}$ morabitinos, tantum michi et vob is bene complacuit (FERNANDES 1991: 142). grato habeo vobis uxori mee domne Sancia Petri de isto amore quam mihi facitis et laudo et confirmo istam cartam medietatis et plazum quod mecum facitis (VENTURA 1992: 235). 
pro amore domni Simeonis ${ }^{85}$

pro multo auxilio et amore quem nobis facistis et fecistis (ibidem, p. 236).

vocate maiordomum de regalengo et date ei pro foro $[\ldots]$ et pona te pede de lagar III vices non plus et faciat vobis bonum amorem (ibidem)

quod ipse propter istum amorem quod sibi facimus teneatur juvare monasterium nostrum (ibidem, p. 237)

et pona te pede de lagar III vices non plus et faciat vobis bonum amorem ${ }^{86}$

Como se pode verificar nos passos transcritos, a expressão «fazer amor de» é usada ou para referir a doação de um bem («fazer amor de» um bem = doar) ou para justificar uma doação (doa-se um bem, em reconhecimento da expressão de amor daquele a quem se doa).

O valor semântico da palavra «amor» aproxima-se do que tem, por exemplo, na cantiga de milagre de Santa Mania 293, onde são referidos os bens recebidos por um jogral pelo trabalho artístico: «Esto foi en Lonbardia dun jograr remedador / que atan ben remedava, que avian en sabor / todos quantos lo viian, e davan-lle con amor / panos e selas e frẽos e outro muito bon don» (METTMANN 1986-1989, vol. 3, p. 81). E repare-se ainda haver esta mesma aproximação semântica do termo «amor» à doação de bens, na Demanda do Santo Graal, quando o rei Artur, depois de todos os cavaleiros da Távola Redonda serem nutridos dos alimentos que mais desejavam, comenta: «Certas, amigos, muito deviamos a seer ledos, que Deos nos mostrou tam gram signal damor, que em tam bõa festa como oje de Pinticoste nos deu a comer do seu santo celleiro» (PÍEL 1988: 16). Sublinho que, de acordo com o passo em que a expressão ocorre, é «Don Estevan» que «recebe amor», ou seja, recebe bem ou benefício ( «que ja por ome que vos faça amor / sol non catades $\gg$ ), não fazendo sentido, portanto, entender que o receba de quem o serve. No início da cantiga, no entanto, o sujeito não se refere ainda ao momento presente, como no restante da cantiga. Refere-se à reputação de «Don Estevan» e a certa situação em que se apoia a fama do visado na cantiga: «Don Estevan tan de mal talan / sodes que non podedes de peior / que ja por ome que vos faça amor / sol non catades, tal preço vos dan». Ou seja, «Don Estevan» tem a reputação de ignorar até aqueles de quem recebe benefícios, o que é considerado o pior de todos os comportamentos («tan de mal talan / sodes que non podedes de peior»). Esta será portanto uma referência ao passado, uma vez que se trata de situação sobre que

85 Concessão a D. Simão Soares, mestre de Avis, da igreja de Santa Maria de Beja e seu padroado (venturA 1992: 236).

86 Documento de Afonso III, Ventura (1992: 236). 
se construiu a reputação de «Don Estevan». A situação descrita por Vuitorom tem correspondência com o sucedido entre Joam Viegas de Portocarreiro e Sancho II, que beneficiou o Arcebispo e acabou traído por ele. Lembra paralelamente a lenda de frei Gonçalo de Amarante, que beneficiou o sobrinho e acabou maltratado à paulada, ameaçado por cães de caça famintos, vendo negado o próprio alimento. Apoia a interpretação destes versos como uma referência à reputação de Joam Viegas, construída a partir do sucedido entre este e Sancho II, o facto de, na outra cantiga que Vuitorom dedica a «Don Estevan», a mesma terminologia, e outra afim, ser usada para referir os benefícios que «Don Estevan» recebeu de Sancho II, queixando-se de serem insuficientes. Depois do momento inicial da cantiga, já não se voltará a falar de «amor»a «Don Estevan», mas do serviço que os «omens» de «Don Estevan» lhe prestam.

$\mathrm{O}$ termo «ome» não tem, portanto, nos primeiros versos da cantiga, o sentido de vassalo, que é comum e que assumirá, a partir do quinto verso. Também no final da cantiga, quando vem acompanhado da alternativa feminina, o termo volta a assumir o sentido geral («non cataredes ome nen molher»).

Tal como na cantiga de Tenoiro anteriormente analisada, o verbo «ver» não tem o papel determinante que tem noutras cantigas do conjunto, mas o sinónimo «catar» sim. Ocorre em todas as estrofes integrado na expressão «catar por» («ja por ome que vos faça amor / sol non catades »; «Pois non avedes por om'a catar»; «non catades por quen / vos faz serviço») e, na terceira estrofe, desacompanhado da preposição («non cataredes ome nen molher / que non querades trager come can»).

O sentido da última ocorrência do verbo («non cataredes ome nen molher / que non querades trager come can») é clara: «catar» significa «olhar para», «ver». Já relativamente à expressão «catar por» haverá vantagem em esclarecê-la melhor, até considerando a insistência nela. As ocorrências tanto nas cantigas quanto na prosa afastam o sentido desta expressão do significado de proteção relacionado com os laços feudo-vassálicos, ou outros afins, que poderíamos esperar, considerando a alusão ao serviço recebido. A seguinte ocorrência da expressão «catar por» deixa bastante claro o sentido «importar-se com», «dar importância a»:

tomou logo aquella espada cõ que os escabeçava e matou com ella mais de viinte mouros algaziis que estavã arredor delle, segundo conta a estorya. Mas os mouros nõ catarom por as feridas que elle dava e ajuntaronse a elle tantos que o filharom aas maãos e cortarõlhe a cabeça (CINTRA 1984, vol. 3, p. 142).

Outras ocorrências confirmam este sentido, observando-se também a expansão para a ideia de dar atenção àquilo a que se atribui importância. 
Mas vos catarlhes yades os agoyros, como amo, e padrinho, e elles nõ quereriam catar por elles, por que lhes doya a mynha prison, por que jazia ẽ cativo (CINTRA 1984, vol. 3, p. 145).

- Senhor, vos partistes os reynos e destes a cada hũu de nos o que tevestes por bem. E agora a mi parece que nem hũu destes meus irmãaos nõ querẽ catar por o que vos dissestes que dessemos a dona Orraca e a dona Elvira algũa cousa em que vivessem (ibidem, p. 341).

E el rey nõ quis catar por nẽ hũa destas cousas; ante se foi pera Castella ao iffante dom Affonso e rogouo que veesse cõ elle a Portugall e que, despois de sua morte, que lhe leixaria o regno (CINTRA 1990: 239).

E en aquesto se acordaron aqueles quarẽeta e çinquo cavaleiros e fezeron de sy hũu tropel e acordarõsse de nõ catar por outra cousa se non por passar pellos mouros e chegar aa porta do castello (ibidem, p. 423).

«Don Estevan» é portanto acusado de não se importar com aqueles que o servem, de não lhes atribuir nenhuma importância. Esta é uma acusação diferente da acusação de falta ao dever de proteção, em âmbito feudo-vassálico, sendo o verbo «guardar», neste caso, mais habitualmente usado.

Também convirá esclarecer que o termo usado para designar o animal referido na segunda estrofe ( $\ll$ se avede-la besta mester / se vo-la ome toste non trouxer $\gg)$, além de ter sido usado para designar toda a espécie de animais ( $\ll \mathrm{E}$ contam as estorias que forom hy tragydos desta vez leõoes e elifantes e bubelos e outras bestas e anymalias muy mais estranhas que estas, dellas que seria longa cousa de contar $\gg$ (CINTRA 1984, vol. 2, p. 108), no contexto doméstico, abrangia as diversas espécies que se podiam cavalgar, como se pode inferir do seguinte passo:

E esto durou tres meses, de guisa que nõ ficou na villa besta nem hũa pera cavalgar se nõ tres cavallos e hũa mua (CINTRA 1990: 88).

A palavra «besta» é portanto mais abrangente, ocorrendo por vezes especificada (besta muar, besta de servir: $\ll$ E morreron en aquelle anno muitos cavallos e bestas de servyr per mingua dos mantiimentos que non avyam $\gg{ }^{87}$ ), e embora designe frequentemente o cavalo que distingue o cavaleiro, não raro aparece associada a outras figuras, como se pode verificar nos passos que se seguem:

87 Cintra (1990: 339). 
E filharom peça de mui boos cavalleiros e fezerõnos vestir como mercadores, ca elles eram cristãaos e vassallos do conde dom Ilham. E carregaron bestas d'armas e d'outras cousas, assi como de mercadaria, e entraron na villa dous e dous e tres e tres, assi como melhor podyam (CINTRA 1984, vol. 2, p. 341).

[...] disseronlhe novas de Eylata, molher que foy de rey Rodrigo, en como era muy boa dona e muy fremosa e de muy grande linhagen; e que era natural de Africa. E mãdou logo por ella; e mãdoulhe dar bestas e aver e servos e servas e todallas cousas que mester ouvesse ataa que chegasse a elle (ibidem, p. 349-350).

Deitou un frad'a pacer sas bestas que comprara, e porque as non achou ali $u$ as deitara,

[i]rado-los-á el-Rei (DIONÍsIo 1992: 145).

A impaciência referida na cantiga a propósito da espera pela besta teria alguma justificação, a julgar por semelhante impaciência mencionada a propósito de outra figura na Crónica geral de Espanha de 1344:

[...] quando chegou aa porta de Visagra, mandou os messejeiros que se fossem diante e o fezeem abrir a el rei. E elle, como o soube, nõ esperou besta, mas acudio a pee, quanto mais pode hyr, a receber el rei dom Afomso (CINTRA 1984, vol. 3, p. 412).

Ao contrário desta figura que, impaciente com a necessidade de esperar pela preparação e apresentação da besta, segue a pé, a reação de «Don Estevan» é de fúria contra quem o faça esperar.

Os cães em que a cantiga insiste são animais frequentemente associados à traição através do insulto, ou usados como instrumento de tortura de traidores, como se poderá apreciar nos passos a seguir recolhidos. Num destes passos, os cães são escolhidos como companhia inferior de refeição. Compreende-se que estes animais, companheiros e instrumentos de caça, mas também de defesa e ataque, que se alimentariam rente ao chão, seriam tão mais apreciados e tão mais úteis quanto mais ferozes e, claro, tão mais ferozes e implacáveis quanto famintos. $\mathrm{O}$ reverso desta medalha seria porventura a violência constante entre os cães na luta pelo alimento, e a necessidade de violência sobre eles para os controlar. Será difícil para o ocidente da atualidade, que associa estes animais à fidelidade ( «o melhor amigo do Homem») e em que o alimento abunda, aceitar que, na cultura medieval, eram vistos como animais cuja fome tornava capazes da feroci- 
dade mais violenta, da traição mais cega ${ }^{88}$. Não é por acaso, no entanto, que quando, na Demanda do Santo Graal, a ofendida filha de Ypomenes é questionada sobre como pretende ver castigado o traidor, ela responde que quer vê-lo atirado a cães, sim, mas acrescenta um pormenor: que os cães não tenham comido durante sete dias. A fome deixá-los-ia incapazes de obediência e, portanto, perfeitos agentes de castigo e vingança.

Asi meteu rei Ypomenes seu filho em preson pola deslealdade [de] sa filha [... El-rei preguntou sa filha de qual morte queria que seu irmão morresse. «Eu quero», diss'ela, «que o deitem aos cãaes, e os cãaes», disse ela, «sejam jej[ũu us de VII dias quando lho ouverem a deitar» (PÍEL 1988: 419).

Vejam-se outras ocorrências, na prosa medieval, da associação entre cães e traidores ${ }^{89}$ :

E o iffante dom Garcia, quando aquello vyo, com grande pesar que ende ouve, pero que estava preso, começou de os doestar, chamandoos treedores e cãaes. E elles, quando esto virom e que os assy doestava, matarõno ẽtom. E a iffante dona Sancha, cõ grande coita que delle avya, deitavasse sobre elle. E o treedor de Fernã Laynez tomouha pellos cabellos e derribouha per hũas escalleiras ajuso (CINTRA 1984, vol. 3, p. 238).

- Vos mẽtides come grãde aleyvosa, ca vos bastecestes todas esta treiçõoes e males que elle fez! E vos erades senhora e raynha das mynhas fortellezas! Daquy adyante vos desafio o corpo, ca eu mandarey a dom Mudarra Gonçallvez que vos faça queymar ou mandarey as vossas carnes espedaçar a cãaes. E a vossa alma seera perduda pera sempre! (ibidem, p. 171).

Mas el por a treiçõ que elles fezerom, mandou cortar as cabeças aos mandadeiros que lha levarõ e deitallas aos cãaes (CINTRA 1990: 375).

E talvez não seja bem assim, se considerarmos que, em outubro de 2019, o Presidente dos Estados Unidos anunciou ao mundo a morte do líder do Daesh dizendo: «morreu como um cão, morreu como um cobarde».

89 No Cantar de Mio Cid, os infantes de Carrión são tratados como «canes traidores»: «Dezid qué vos merecí, ifantes de Carrión / en juego o en vero o en alguna razón? / aquí lo mejoraré a juvizio de la cort. / A quém descubriestes las telas del coraçón? / A la salida de Valençia mis fijas vos di yo / con muy grand ondra e averes a nombre; / quando las non queriedes, ya canes traidores, / por qué las sacávades de Valençia sus honores? / A qué las firiestes a çinchas e a espolones? / Solas las dexastes en el robredo de Corpes, / a las bestias fieras e a las aves del mont. / Por quanto les fiziestes menos valedes vos. / Si non recudedes, véalo esta cort.» (MENÉNDEZ PIDAL 1931: 328-329). 
Também na Lírica Galego-Portuguesa, tanto profana quanto religiosa, a associação do cão ao mal e à traição é recorrente. Na cantiga de Santa Maria 17, a Virgem recomenda a certa mulher que despreze um «maestre» (de que o diabo se disfarça) tratando-o como «mẽos que can» (METTMANN 1986-1989, vol. 1, p. 104). Note-se que o papel da personagem do «maestre» é precisamente o de denunciar, trair, pondo, portanto, em risco a vida da mulher.

$\mathrm{Na}$ lírica profana há o caso das cantigas de amigo de Joam Garcia de Guilhade onde o sujeito feminino se dirige ao amigo chamando-lhe «cabeça de can» e lhe diz, na segunda estrofe: «Olhos de traedor, / vĩinde ja, ca ja vos perdoei», acrescentando paralelisticamente, na terceira estrofe: «Ai cabeça de can, / viide ja, ca ja vos perdoei $\gg^{90}$.

Na cantiga Veestes-me, amigas, rogar, a designação do amigo como «cabeça de cão» volta a ser associada (se não explicada) à traição por ele perpetrada: «Cabeça de can perdudo / é, pois non á lealdad'e / con outra fala en Guilhade, / é traedor conhuçudo» (COHEN 2003: 251).

$\mathrm{Na}$ lenda da dama pé de cabra, descreve-se uma cena igualmente exemplificativa tanto da forma como eram tratados os cães, como da violência de que, pelo alimento, eram capazes:

E ũu dia, foi ele a seu monte e matou ũu porco mui grande e trouxe-o pera sa casa e pose-o ante si u siia comendo com sa molher e com seus filhos. E lançarom ũu osso da mesa, e veerom a pelejar ũu alão e ũa podenga sobr'ele em tal maneira que a podenga travou ao alão em a garganta e matou-o. E dom Diego Lopez, quando esto vio, teve-o por milagre, e sinou-se e disse: «Santa Maria val, quem vio nunca tal cousa!» ${ }^{91}$.

No comentário geral à cantiga de Airas Peres Vuitorom, haveremos de começar por notar que o mesmo recurso ao termo «amor» (e «desamor»), semanticamente investido da ideia de receber bens, permite a identificação, nesta cantiga, da referência a Sancho II, que é explícita na cantiga Don Estevan diz que desamor.

Em qualquer caso, a identificação de «Don Estevan» com Joam Viegas de Portocarreiro torna clara a alusão inicial da cantiga à situação que determinou a reputação do visado como alguém que não se importa nem mesmo com aqueles a quem deve a concessão de benefícios: «Don Estevan tan de mal talan / sodes que non podedes de peior / que ja por ome que vos faça amor / sol non catades,

Cohen (1996: 7-8, 27; 2003: 247) considera-o um insulto.

Mattoso (1980, vol. II/1, p. 139). Marcenaro $(2014: 114,155)$ considera que «trager come can» é uma referência ao ato homossexual. Não explica, no entanto, este entendimento. 
tal preço vos dan». Assim terá acontecido entre Sancho II e Joam Viegas, quando o primeiro terá exercido a sua influência no sentido de o segundo ser eleito arcebispo de Braga e este lhe retribuiu com a traição participando ativamente no movimento para o depor.

O entendimento desta introdução da cantiga, especialmente da expressão «fazer amor de» com o sentido de atribuir bens ou benefícios, permite precisar o sentido da recorrente expressão «trager como can», que corresponderá ao reverso daquela: trazer à míngua, negar benefícios. Como referido, os cães, usados frequentemente em atos de castigo e vingança, mas também na caça, eram tão mais eficazes quanto famintos, ou seja, quanto mais lhes negassem o alimento, mesmo que, para os controlar, fosse necessário usar de violência. «Trager como can» será, portanto, nesta cantiga, o contrário de «fazer amor de» (beneficiar) e, segundo adverte o sujeito, tal como aconteceria com os cães famintos, terá, a prazo, a consequência do abandono do serviço («os que vos serven non vos serviran»), o que já declarava o vilão na cantiga de Tenoiro anteriormente analisada.

O cão simbolizava, por outro lado, como vimos, o traidor, precisamente porque, quando faminto, agia sem lealdade atacando o que quer que pudesse saciá-lo. Sem nunca se usar a palavra traição é deste crime que sempre se fala nesta cantiga: «Don Estevan» de mau caráter traiu quem o beneficiou, mas qualquer motivo the serve para retirar benefícios àqueles que o servem e castigá-los desproporcionalmente como se fossem traidores («trager como can»), arriscando-se a ser abandonado e a ver-se sem ninguém que o servisse, o que seria especialmente grave para quem, como vimos, tanto dependia dos seus dependentes.

Os motivos que levam «Don Estevan» a agir como descrito estabelecem um vínculo entre esta cantiga e a de Tenoiro anteriormente analisada. $\mathrm{O}$ motivo mais imediato é a fúria («sanha»), que domina o visado e o faz agir irracionalmente. Mas fica a questão sobre o que espoleta a fúria e, na resposta a esta questão, o texto evolui em decrescendo para compor o retrato de um homem que se enfurece a pretexto de quase nada ou mesmo sem motivo nenhum. Na primeira estrofe, é o mínimo desvio que o enfurece («se vos desvia quan pouco xiquer»), no que podemos encontrar uma alusão à dependência de dependentes que já tínhamos encontrado anteriormente na cantiga Don Estevan que Thi non gradecedes, de Coelho, e em Don Estevan tan de mal talan, de Vuitorom. «Don Estevan» não pode passar sem os que o servem e por isso se enfurece, se se afastam minimamente. Depois, a fúria é motivada por não lhe trazerem a «besta» depressa, se dela necessita ( «se avede-la besta mester / se vo-la ome toste non trouxer»). Sendo a operação de preparar uma «besta» para cavalgar naturalmente demorada, esta é já uma alusão a exigência pouco razoável. Mas o sujeito da cantiga termina dizendo suspeitar de que a sanha de «Don Estevan» o levará a querer 
«trager como can» qualquer homem ou mulher (entre os que o servem) onde poise o olhar, ou seja, sem nenhum motivo para tal: «se vos sanha, como sol, preser / non cataredes ome nen molher / que non querades trager come can». É importante notar o cuidado do sujeito em sublinhar que nenhum dos atos que espoletam a sanha de «Don Estevan» corresponde a falha de serviço ou deslealdade, o que deixa claro o desfasamento entre o comportamento do visado e a realidade que poderia motivá-lo: «E sêrvia-vos ome quanto puder / se vos desvia quan pouco xiquer / ides log'ome trager come can».

O sujeito empenha-se, em resumo, em demonstrar que «Don Estevan» aproveita todos os pretextos para tratar «come can» os que o servem, ou seja, para economizar na recompensa de serviços prestados, para trazer à míngua, desprezando e eventualmente forçando ao serviço não recompensado a pretexto de traição. O motivo para o comportamento de «Don Estevan», que se esconde por trás do pretexto que é a fúria, será, portanto, o mesmo motivo de que Vuitorom já o acusava na cantiga Don Estevan diz que desamor: a cupidez. Mais uma vez, há uma mudança de direção, dado que, na primeira cantiga de Vuitorom, se trata da cupidez que levou «Don Estevan» a escolher o partido do Conde na expetativa de ganhar mais, ao passo que, na segunda cantiga, se trata da cupidez de quem procura todos os pretextos para evitar recompensar os que o servem. Também na história de frei Gonçalo de Amarante, é a cupidez que orienta o comportamento do sobrinho beneficiado. 


\section{Roi Queimado}

I 1 Don Marco, vej'eu muito queixar ${ }^{92}$

Don Estevan de vós ca diz assi

que pero foi mui mal doent' aqui

que vos nunca quisestes trabalhar

II

5 de o veer neno vistes, mais ben

jura que o confonda Deus por én

se vos esto per caso non passar.

III Qual desden lhi vós fostes fazer

nunca outr'om'a seu amigo fez

10 mais ar fará-vo-l'outra vez:

se mal ouverdes, non vos ar veer,

ca x'é el ome que x'á poder tal

ben come vós, se vos ar veér mal,

de vos dar én per lo vas'a bever.

15 Diz que o non guii Nostro Senhor se vos mui ced'outro tal non fezer: non vos veer quando vos for mester poi'lo non vistes. Aind'al diz peior un verv'antigo con sanha que á:

20. como lhi cantardes bailar-vos-á ca non á por que vos baile melhor.

O único lugar onde creio que a fixação desta cantiga necessita de emenda significativa, embora ínfima, é no verso 7. Diz-se na primeira estrofe que «Don Estevan» se queixa de Don Marco, por não o ter visitado aquando de doença

92 B1388 /V997 Aparato crítico - 6. uira BV; 7. casa BV; 14. den9 B; na sabeuer B; 16. uinj B; 18. amdal B; cumdal v; 20. baylarn9 а в baylam9 a v. - A presente edição difere da de R. Lapa (1970a: 615) no verso 7, onde os testemunhos apresentam a lição «casa», conservada por R. Lapa e pelos editores subsequentes (CMGP e Lorenzo Gradín e Marcenaro 2010: 264). Difere igualmente nos dois versos (8 e 10) onde R. Lapa fez alterações sem outro significado, além do de regularizar a medida do verso. No verso 8 , a integração foi reconhecida («lhi vós fostes [i] fazer»), mas, no verso 10, não («mais ar fará-vos ele»). Em CMGP dispensa-se a integração no primeiro caso, ao contrário de Lorenzo Gradín e Marcenaro (2010: 264), onde é conservada. No segundo caso, em CMGP repete-se a integração reconhecendo-a («fará-vo-lo [el] »), embora se mantenha a lição dos manuscritos. Já em Lorenzo Gradín e Marcenaro (2010: 264) a integração é diferente («[assim] faravol'»), embora o objetivo seja o mesmo. No verso 14, onde R. Lapa e todos os editores que se lhe seguiram leram «pelo vaso», creio que devemos ler a abreviatura constituída por «p»com sinal de abreviatura sobreposto como «per», para o que aponta a lista de abreviaturas recolhida por Monaci (1875: 445): «per lo vas'a bever» e não «pelo vas'a bever». 
grave. Dirigindo-se a Don Marco, o sujeito acrescenta nos versos finais da estrofe: «jura que o confonda Deus por én / se vos esto per caso non passar». Em ambos os manuscritos, lê-se «casa» em vez de «caso», lição que tanto R. Lapa quanto os restantes editores aceitaram. O filólogo explica assim a interpretação que faz do verso: «se a doença vos não passar por casa e não vos pagar na mesma moeda»

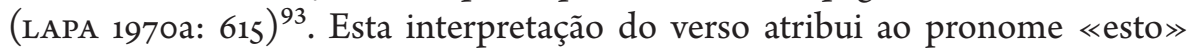
o sentido de situação igual à passada por «Don Estevan», ou seja, a doença: «se não fizer isto, ou seja, a doença passar por vossa casa». De acordo com esta interpretação, teríamos de ler no verso 6 («jura que o confonda Deus por én») a expressão da convicção de «Don Estevan» de ser capaz de provocar igual doença em Don Marco ( «jura que o confonda Deus por én / se vos esto per casa non passar»), o que não faz sentido.

Julgo necessário supor uma simples confusão entre um «o» e um «a $\gg$ que, num antecedente direto ou indireto dos cancioneiros в e v, tenha transformado a palavra «caso», sinónimo de «preito» jurídico, na palavra «casa». O contexto de um verso de sentido e sintaxe menos óbvios favorece o engano, que é, de resto, bastante comum ${ }^{94}$.

O que «Don Estevan» jura fazer, invocando para si próprio o castigo de Deus, de modo a reforçar a credibilidade das suas intenções (CORREIA 1997a), é processar juridicamente Don Marco pela afronta de o não ter socorrido quando esteve doente. O pronome «esto» refere-se ao ato de abandono de «Don Marco»: se aquilo, ou seja, a afronta do abandono não for tratada como um caso jurídico ( «se vos esto per caso non passar»).

Nas Flores de dereyto encontramos ocorrências do termo «caso» com o sentido de processo jurídico, conforme se pode apreciar nas citações que se seguem:

Seruo nenhuu nõ pode seer proua senon en feyto de seu senhor en. .IIJ. cousas synadamente e nõ mays. E as cousas son estas: Se seu senhur foy mayordomo del Rey ou de princepe alguu e furtou ou ascondeu tributos que recebeu por el. Ou se o senhur fuy acusado dalgũha conspiraçõ. que fezesse contra persoa del Rey ou de seus filhos. Ou se fosse acusado d'adulteryo que fezesse. En estes casos subredictos e nõ en mays pode seer o seruo proua contra seu senhor. e dementre que dixer o testimonho en qualquer destes casos deuen lhy dar boos azoutes que diga a uerdade do

Em CMGP levanta-se a possibilidade, com dúvidas, de haver alusão a uma doença contagiosa.

94 Vejam-se diversos exemplos de troca de $\ll$ o $\gg$ por $\ll$ a $\gg$ na lista $\ll$ Tavola dei Principali Errori che si osservano nella scrittura del codice», Monaci (1875: XXVIII). 
que lhy preguntarẽ. ca nõ deuẽ seer creudos os ditos dos seruos. en taes casos se nõ forẽ tormentados (FERREIRA 1989: 39).

Geeralmente Senhor deuẽ seer recebidas as prouas poys que o pleyto é começado por resposta. E antes non, mas por razon que a uerdade nõ seya asconduda por ocasyõ de mingua de prouas. Casos sũ sijnados eno dereyto en que se podẽ receber prouas. pero que o pleyto non seya cõmeçado (ibidem, p. 35).

Já o sentido de «passar per» é, neste caso, metafórico. O sentido literal é que a afronta de «Don Marco» (sintetizada no demonstrativo «esto») atravessará um processo jurídico. Veja-se a forma de expressão semelhante com o mesmo verbo seguido da mesma preposição:

E elles tomarõno e levarõno ante el rey Lemedon e elle preguntoulhe por que dissera aquella pallavras. E Rotas disse que por dizer verdade, ca todas aquellas gentes avyam de passar per espada e os edificios per fogo (CINTRA 1984, vol. 2, p. 35).

Assim como neste caso as gentes seriam atravessadas por espada e os edifícios por fogo, também o processo jurídico seria atravessado pela afronta de Don Marco, o que é uma forma de dizer que Don Marco seria levado à justiça por aquele ato, assim como a formulação da Crónica geral de Espanha significa que as gentes seriam mortas à espada e os edifícios queimados.

A identificação de Don Marco e uma melhor avaliação da gravidade dos atos de que é acusado poderão clarificar este passo do texto.

«Marco» é um nome raro na onomástica do período, mas os editores anteriores renunciaram à identificação desta figura. «Embora o nome não seja muito vulgar na época, não dispomos de dados que nos permitam identificar esta personagem », afirma-se em CMGP. Os editores de Roi Queimado esclarecem não terem encontrado nenhum outro Marco na chancelaria de Afonso III nem na de D. Dinis, tendo apenas encontrado o patronímico e topónimo «Marco» em documentação galega do final do século XIV e meados do século XV (LORENZO GRADÍN E MARCENARO 2010: 267).

A dificuldade dos editores anteriores decorreu provavelmente do facto de terem procurado respostas na documentação mais próxima da nobreza. Perto da documentação episcopal, isto é, perto de «Don Estevan», arcebispo de Braga, o nome, efetivamente raro, ocorre num documento datado de 1241, precedido do caraterístico «Dom». Não menos importante no xadrez deste caso, «Domnus Marcus $\gg$ era, à data, segundo esclarece o documento referido, scriptor do bispo da Guarda, mestre Vicente, figura da maior importância na corte de Sancho II, 
onde ocupou o lugar de chanceler até 1236. O brusco afastamento de mestre Vicente a partir desta data, com graves consequências na chancelaria, que a partir de então se desorganiza, e para o próprio Rei, que a partir daquela data inicia o seu caminho para a deposição, faz suspeitar do envolvimento de mestre Vicente num golpe palaciano (FERNANDES 2010: 273-274). Afastado da corte e caído em desgraça junto do Rei, quando as violências contra o clero começam, e tem início o período de violência e desordem que grassa no reino até depois da deposição de Sancho II, mestre Vicente foi uma das suas primeiras vítimas. Ironicamente, se o Martirológio dos cónegos regrantes e benfeitores da Congregação de Santa Cruz não contém erro, mestre Vicente apenas sobreviveu alguns meses a Sancho II, tendo morrido em setembro de 1248 (COSTA 1963: 56). Significa este dado que, se é certo que esta cantiga lhe faz alusão, como julgo fazer, a composição deverá ser anterior a esta data.

$\mathrm{O}$ documento em que o nome de Dom Marco é mencionado, feito em Ciudad Rodrigo, trata de questão em curso com o bispo de Évora sobre a divisão das respetivas dioceses. Nele, o bispo da Guarda, mestre Vicente, compromete-se a aceitar as decisões que, no caso, fossem tomadas pelo chantre de Lisboa, Dom Ricardo, e por D. Peres, arcediago da Covilhã, aos quais se poderia juntar o bispo de Lisboa, D. Arias, se fosse necessário ${ }^{95}$.

Sendo scriptor ao serviço de mestre Vicente, quer fosse de carreira quer o tivesse sido ocasionalmente, é provável que Dom Marco pertencesse ao cabido ${ }^{96}$. Havia, também, a possibilidade de pertencer à sua capela, uma vez que, como afirma M. C. Cunha, a partir do século XII, surgem os primeiros documentos episcopais subscritos pelos capellani episcopi, o que decorria de um esforço para controlar a chancelaria da sé. Em Braga, por exemplo, alguns clérigos do Arcebispo também se intitulam notários episcopais e serão eles que, a partir do século XIII, constituirão a chancelaria episcopal (CUNHA 2001-2002: 465-466). Conhecido o perfil e a história de mestre Vicente à frente da chancelaria de Sancho II, onde tudo fez para assegurar que tudo controlava, nada de mais natural haveria que tivesse tomado todas as medidas necessárias para controlar também a chancelaria da sé da Guarda. Don Marco seria, portanto, um clérigo muito próximo de mestre Vicente; seu scriptor, ou seja, seu notário. É contra ele que, segundo a cantiga de Roi Queimado, o arcebispo de Braga, Joam Viegas de Portocarreiro, tratado nas

95 Costa (1963: 455-456). S. Costa manifesta alguma dúvida sobre a datação deste documento: «Temos certas dúvidas sobre a data do documento por haver aí referências ao sucessor de D. João Rolis, bispo de Lisboa, que, a darmos crédito a D. Rodrigo da Cunha, ainda vivia.» (1963: 456).

96 É a conclusão de M. C. Cunha sobre os scriptores do arcebispado de Braga: «No que respeita aos scriptores, verifica-se que ao longo de todo o período estudado, a maioria era originária do cabido, situação que nos parece estar relacionada com a existência de uma escola na catedral, que prepararia alguns dos seus alunos para o exercício de funções na Chancelaria» (2001-2002: 464). 
cantigas em análise por «Don Estevan» se insurge, acusando-o de não lhe ter acudido em momento de doença grave; é ao notário de mestre Vicente que ameaça, com sanha.

A propósito da afronta de que Don Marco é acusado por «Don Estevan», importa considerar a importância da unção dos doentes. É na Bíblia (Tiago, 5, 13-15) que se encontra o que se considera o fundamento da Unção dos Enfermos:

Quando alguém estiver doente, mande chamar os responsáveis da igreja, para orarem por ele, derramando óleo sobre ele, em nome do Senhor. Esta oração, feita com fé, dará a saúde ao doente e o Senhor o aliviará (Bíblia Sagrada 1993).

«Mui mal doente» estava «Don Estevan» quando em vão esperou a visita do clérigo e notário de mestre Vicente. A expressão que sublinha a gravidade da doença sublinha igualmente a necessidade de ação diante dela. Ou seja, da unção que poderia salvar-lhe a vida ou encomendá-lo à eternidade. Em ambos os casos, a falta ao chamamento é grave. Tendo D. Marco sido scriptor, e, portanto, não podendo ser visto como um dos «responsáveis da igreja», referido em Tiago, 5, 13-15, Roi Queimado estaria provavelmente a referir uma comitiva, liderada por mestre Vicente, de que o scriptor faria parte. Ou seja, em caso de doença grave do arcebispo Joam Viegas de Portocarreiro, o bispo da Guarda, mestre Vicente, não acudiu para lhe dar a unção dos enfermos. E é desta afronta que trata, na verdade, a cantiga de Roi Queimado. O Arcebispo promete vingar-se processando D. Marco. Não promete vingar-se de mestre Vicente processando o antigo chanceler de Sancho II, mestre em leis. Apenas o seu scriptor. Tal como noutras cantigas, «Don Estevan» é mostrado em humilhante conflito com inferiores, junto dos quais não consegue fazer-se obedecer.

Tenha o caso da doença acontecido ou não, esta é, mais uma vez, uma forma inteligente de retratar alguém que não é respeitado nem mesmo pelos que, estando abaixo dele na hierarquia clerical, parecem ter mais conhecimento e até poder. Mas também o retrato de alguém suficientemente cobarde para dirigir toda a sua fúria de vingança não contra os que verdadeiramente a mereceriam, mas contra os mais fracos. Não contra o sábio e influente mestre Vicente, mas contra o scriptor D. Marco, que pretende passar por responsável por uma afronta cujo verdadeiro responsável não tem capacidade ou poder para enfrentar. E também alguém suficientemente tolo para expor a sua fraqueza ao manifestar as expetativas e promessas de retaliação em relação a um inferior.

Provavelmente por ter em mente a locução «vaso de noite» ou «vaso noturno», R. Lapa considerou que a vingança referida no verso 14 ( $\ll$ de vos dar én per lo vas'a bever») corresponderia a «de vos mandar beber da merda» 
(1970a: 615). Em CMGP considera-se o mesmo significado («penico») para «vaso», embora se indique, para o conteúdo, «fel», o que não se explica facilmente. Os editores de Roi Queimado preferem uma interpretação mais vaga, com o sentido da retribuição («"vi darà da bere altrettanto", ossia "vi ripagherà con la stessa moneta" ${ }^{97}$ ), entendendo a expressão como um provérbio. No entanto, ao contrário do que acontece na última estrofe, não se anuncia haver neste passo um provérbio, e os editores não apontam indícios de que se trate de um provérbio. Por outro lado, todas as pesquisas realizadas para determinar o significado de «vaso» apontam para o sentido de copo ou cálice, onde são servidos líquidos como água ou vinho. Vejam-se alguns exemplos:

E porende aqueles frades veendo que non podian, con este abade que demandaron, fazer as obras que ante fazian, acusavan si meesmos e assanhavan-se contra si porque non podian fazer as obras en que ante soiam se deleitar. E porque os homens de maaos custumes non poden sofrer a vida dos bõõs, começaron a cuidar en como matassen seu abade e per conselho de todos deitaron poçonha no vîho que avia de bever. E quando lhi deron hũũ vaso de vidro en que aquela poçonha andava, cheo de vîho ali hu queria comer, el alçou a mão assi como era custume e fez o sinal da cruz. $\mathrm{E}$ o vaso que estava alonjado del foi logo quebrado pele sinal da cruz que sobr'el fezeron ben como se o quebrantassem con hũa pedra (SILVA 1971: 50, 51).

Enton o escançon entendeu que seu senhor sabia a morte que lhi el queria dar a bever, começou a tremer con medo e mais quis bever o vĩho en que a poçonha andava ca sofrer as pẽas que merecia pola morte que a atan santo homen quisera dar. E, levando ja o vaso do vïho en que a poçonha andava aa boca pera bevê-lo, o santo homen de Deus lhi disse:

- Non-no bevas, mais da-o a min e eu o beverei e tu vai aaquel que cho deu e di-lhi ca eu bevo a poçonha, mais ele nunca seerá bispo.

E enton o bispo fez e sinal da cruz e beveu o vîho en que andava a poçonha seguramente. En aquela hora meesma o arcediagoo que estava en outro logar morreu come se passasse a poçonha pela boca do bispo ao ventre do arcediagoo (ibidem, p. 101).

E des i contarom os bispos e acharom que eram cento e viinte bispos dos tempos, salvo o maior bispo que era cabedel de todos. E havia este de renda quatro tanto em ouro ca cento dos outros. E des i apanharom todolos

97 Lorenzo Gradín e Marcenaro (2010: 268). 
servos e as servas e as vistiduras e os vasos e o ouro e a prata e as bestas e os gaados e todalas cousas que eles podiam haver. $\mathrm{E}$ tanta era a riqueza que nom podia seer contada. E des i Verodax foi-se com toda sa gente pera El Rei Xerxes, e levou consigo os apostolos e os bispos e todalas suas riquezas (CEPEDA 1989, vol. 1, p. 262)

Muitas vezes acaece que, em nas arquetas d'ouro cubertas de pedras preciosas, stam encerradas mui viis cousas, e, em nas arquetas mui viis de madeira, soem seer achadas algũas cousas proveitosas, e os vasos mui fremosos, que som cheos de vinagre, soem dar muitas vezes aos homens a cobiiça de gostar o que jaz dentro, e outros vasos feos em que jaz algũu sabor doce e bõo dentro e leixa-no os homẽes de o catar nem de gostar o que jaz dentro, polo despreçamento da vista do vaso. E, pois, quem quer seer senhor d'algũa cousa nom ha de parar mentes aa grande obra daquel que a faz mais da cousa que se faz. E pois nom spante a vossa vista aquesta nossa vistidura, ca dentro jazem cousas que vos mostrarám a achar a perduravil gloria, e a vida perduravil (ibidem, p. 266).

Ũu bispo, que havia nome Aristodomo, que era princepe de todolos bispos dos templos daquela terra, achegou ali, aquela hora, e houve mui gram pesar e mui gram sanha do que Sam Joanne fezera, que assi confondera seus idolos e seu templo. E, tanto fez com seu poboo, que houverom a haver batalha com Sam Joanne e com os que se a el tomarom. E disse Sam Joanne:

- Di-me, Aristodomo, que poderia eu fazer que te tolhesse essa descreença que trazes em no teu coraçom?

E disse Aristodomo :

- Eu cho direi: beve tu ũu vaso de peçonha que te eu darei. E sabe que a peçonha darei eu a bever a outrem ca a ti, e seera tam forte que os que a beverem seeram logo mortos. $\mathrm{E}$ bem som seguro que, quando a vires, nom a querras bever, e haveras-te a leixar desta sandice que preegas. Mais, se a beveres e ficares são, quero eu fazer teu mandado, senom que faças tu o meu (ibidem, p. 342).

Não me passou despercebida a ligação frequente, nestes exemplos, entre «vaso» e «peçonha», mas creio mais provável que a expressão atribuída a «Don Estevan», um clérigo, para ameaçar Don Marco, outro clérigo, faça alusão a passagens bíblicas. Precisamente aquelas onde se lê que beber de um cálice (ou copo, taça) correspondeu a experimentar provação ou implacável fúria. Tão difícil de suportar, no primeiro caso, que até Cristo pediu escusa. 
Quando iam a caminho de Jerusalém, Jesus chamou os doze discípulos à parte e disse-lhes: «Escutem! Vamos para Jerusalém, onde o Filho do Homem vai ser entregue ao chefes dos sacerdotes e aos doutores da Lei, que o vão condenar à morte. Hão-de entregá-lo aos pagãos, que vão troçar dele, bater-lhe e pregá-lo numa cruz. Mas, ao terceiro dia, há-de reussuscitar.»

A mulher de Zebedeu, acompanhada pelos filhos, aproximou-se então de Jesus e inclinou-se diante dele para lhe fazer um pedido. Jesus perguntou-lhe: «Que é que desejas?» Ela respondeu: «Faz com que estes meus dois filhos ocupem os dois primeros lugares no teu Reino.» Mas Jesus em resposta disse: «Vocês não sabem o que estão a pedir. Podem beber o cálice de amargura que eu tenho de beber?» Eles responderam: «Podemos, sim!» Jesus acrescentou: «De facto, vocês hão-de beber do meu cálice», mas isso de ocuparem os dois primeiros lugares não me compete a mim concedê-lo. Esses lugares são para quem meu Pai os preparou.» (Mateus, 20, 17-23).

Depois disso, Jesus, acompanhado pelos discípulos, foi para um lugar Getsémani e disse-lhes: «Sentem-se aqui, enquanto eu vou ali mais adiante orar.» Levou consigo Pedro e os dois filho de Zebedeu. Nisto começou a sentir-se angustiado e cheio de aflição, e exclamou: «Sinto uma tristeza de morte! Fiquem aqui e estejam atentos.» Foi um pouco mais para diante e, incinando-se até ao chão, orava assim: «Meu pai, se é possível, afasta de mim este cálice de amargura. No entanto, não se faça a minha vontade, mas sim a tua.» (Mateus 26, 36-39).

Jesus afastou-se outra vez para ir orar e dizia: «Meu pai, se este cálice de amargura não pode ser afastado de mim sem que eu o beba, faça-se a sua vontade.» (Mateus 26, 42).

Desperta! Desperta, Jerusalém e levanta-te!

Já bebeste da mão do Senhor a taça da sua ira;

bebeste dela até à última gota, a ponto de ficares atordoada.

De todos os filhos que deste à luz, Não há nenhum que te guie, de todos os filhos que criaste, nenhum que te segure pela mão.

As desgraças caem sobre ti uma atrás da outra, ruína e destruição, fome e guerra.

Quem é que se compadece de ti? 


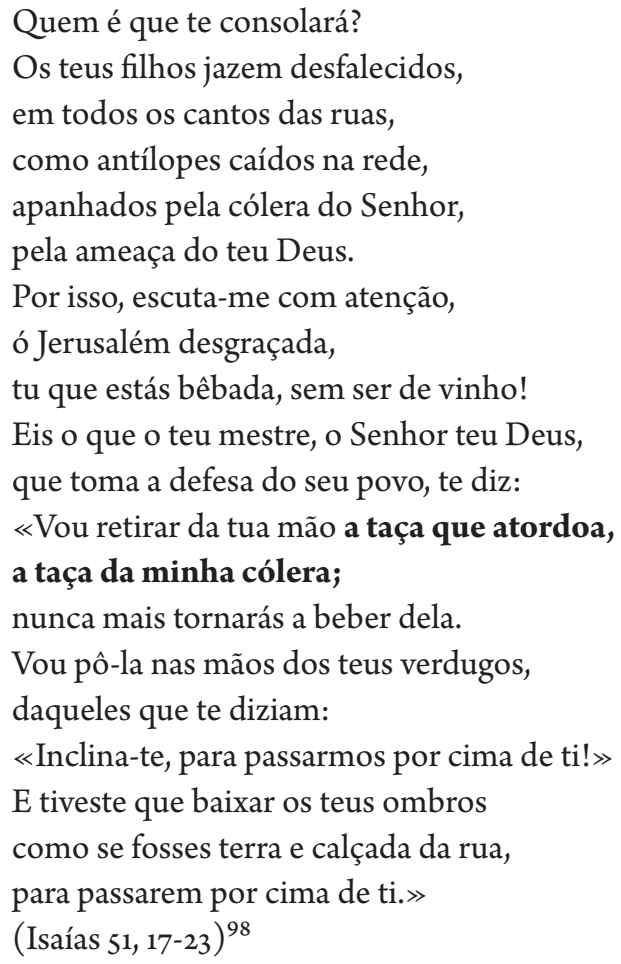

Creio, portanto, que a expressão «dar a beber pelo vaso» é uma tradução precoce para português da expressão bíblica que tanto «Don Estevan» quanto Don Marco, quanto os trovadores conheceriam em latim (Potestis bibere calicem, quem ego bibiturus sum?). Exprime com ênfase inquestionável o sofrimento que «Don Estevan» pretende infligir a Don Marco pela afronta recebida.

A segunda cantiga de Roi Queimado contra «Don Estevan» é, ao mesmo tempo, a mais rica de referências clericais, já explicadas, e a menos insistente nas repetições que caraterizam o conjunto de cantigas; neste caso, o verbo «ver»e a «sanha». O primeiro tem aqui um sentido que não assume em nenhuma outra cantiga: visitar. E, dadas as circunstâncias descritas, compreende-se que se trata de visita com determinado objetivo: o da unção do doente, o da salvação, portanto; como acima explicado. O verbo assume este sentido, quer quando o sujeito se refere ao que Don Marco não fez aquando da doença de «Don

\footnotetext{
98 A expressão «beber do cálice» com o sentido indicado é usada várias vezes por Camilo Castelo Branco, por exemplo, no romance Carlota Ângela: «Fraqueaste, porque a desgraça exigia que eu bebesse o ultimo trago do meu calix.» (1858: 228); «Este calix irremediavel ha de ser tragado» (ibidem, p. 76).
} 
Estevan», quer quando refere o que «Don Estevan» promete não fazer quando for a vez de Don Marco necessitar. Mais uma vez, temos de notar que, embora a insistência no sentido da visão neste conjunto de cantigas, através das repetições do verbo «ver» ou «catar» procurem despertar associações a «Don Estevan», a diversidade de sentidos atribuídos ao verbo convida a descartar a leitura segundo a qual «Don Estevan» teria um efetivo défice de visão. Não é disto que se trata. A alusão ao sentido da visão reforça o jogo de substituição do nome de Joam Viegas de Portocarreiro pelo nome «Don Estevan», numa alusão a Estêvão Soares, cuja alcunha, herdada do pai, era $o$ Torto (zarolho, mas também injusto ou traidor). Por meio de ambos os nomes, podiam os trovadores encontrar coincidências bastantes entre Estêvão Soares, $o$ Torto, e Joam Viegas de Portocarreiro, ambos arcebispos de Braga; ambos, embora em medidas diferentes, traidores do Rei que lhes favorecera a eleição para arcebispos de Braga ${ }^{99}$.

Quanto à «sanha», essencial na caraterização do visado noutras cantigas, é, nesta, mais demonstrada do que referida, embora não deixe também de o ser na última estrofe («Aind'al diz peior / un verv'antigo con sanha que á:»). Existe certo paralelo entre a fúria manifestada por «Don Estevan» contra Don Marco e a fúria manifestada contra o vilão nas cantigas de Airas Peres Vuitorom e Mem Rodrigues Tenoiro, na medida em que, em ambos os casos, «Don Estevan» nos é mostrado a dirigir a sua sanha contra dependentes. Mas a identificação de Don Marco como dependente de mestre Vicente permite-nos refinar o entendimento da sátira de Roi Queimado.

Por um lado, tratando-se «Don Estevan» do arcebispo de Braga e Don Marco de um scriptor do bispo da Guarda - ou seja, um dependente de um dependente do arcebispo de Braga -, a insistência do sujeito em tratá-los como «amigos», em referir o semelhante poder de ambos («á poder tal / ben come vós»); o próprio sentimento de afronta e o impulso de retribuição com igual comportamento corresponde a uma desconsideração social de «Don Estevan», isto é, de Joam Viegas, que assim é colocado ao nível de um dependente de mestre Vicente. Mas será sobretudo uma forma de satirizar o real poder, a real influência e o real posicionamento social do arcebispo de Braga, todos inferiores, na prática, aos de mestre Vicente, apesar de este ser hierarquicamente inferior, uma vez que era (apenas) bispo da Guarda.

Roi Queimado termina a cantiga com uma estocada violenta, em que, de resto, se podem ler insinuações de maior alcance: a imagem de «Don Estevan» 
a dançar ao som da música do scriptor de mestre Vicente, declarando, com ridícula sobranceria, não ter com este dívidas que o obrigassem a dançar melhor.

Dada a ligação entre Don Marco e mestre Vicente, o retrato de fraqueza que aqui encontramos de Joam Viegas de Portocarreiro e a datação deste conjunto de cantigas, é inevitável questionarmo-nos sobre se deveremos ver nesta cantiga uma denúncia de eventual influência de mestre Vicente sobre o arcebispo de Braga. O mesmo mestre Vicente que Roi Queimado aqui mostra a ignorar um apelo de Joam Viegas de Portocarreiro, o qual, apesar de hierarquicamente superior, prefere dirigir toda a sua fúria contra um subalterno.

Para o sentido de desmesurada reação de «Don Estevan», é fundamental, nesta cantiga, o efeito, mais ou menos real, de acumulação. A retaliação prometida por «Don Estevan» tem diversas formas, mas também diversos momentos: promete-se imediatamente um processo jurídico; noutro momento («outra vez») promete-se fazer sofrer de igual modo, sendo esta retaliação repetida com desejo de que o momento chegue depressa («mui ced»). A conclusão que tudo resume («como lhi cantardes bailar-vos-á / ca non á por que vos baile melhor») é também introduzida de forma a criar a impressão de ser acrescentado mais um elemento à acumulação de respostas à afronta: «Aind'al diz peior».

Note-se também a dupla jura que encontramos no texto, cujo efeito é igualmente enfático da reação de «Don Estevan»: «jura que o confonda Deus por én / se vos esto per caso non passar»; «Diz que o non guii Nostro Senhor / se vos mui ced'outro tal non fezer». 


\section{Um retrato que retrata quem o fez}

Concluída a edição e estudo das oito cantigas de escárnio que os trovadores Joam Soares Coelho, Roi Queimado, Airas Peres Vuitorom e Mem Rodrigues Tenoiro elaboraram contra «Don Estevan», podemos em primeiro lugar definir o conjunto como sátira política. «Don Estevan» é atacado por nomeação inadequada, o que constitui uma crítica ao rei, Sancho II, por ter influenciado no sentido da sua nomeação, e ao próprio por incapacidade de desempenhar as funções para que foi eleito. Podemos notar também que o grau de tensão entre os trovadores é, pelo menos aparentemente, reduzido ou nulo, convergindo todos na sátira ao visado.

O retrato que o conjunto das cantigas oferece de «Don Estevan» é bastante pormenorizado. Homem com uma capacidade de entendimento muito limitada, mostra-se incapaz de participar com a mínima competência no «jogo» social ou diplomático, seja em situações de simples convívio, seja em situações de responsabilidade. Devido às incapacidades e insuficiências de conhecimento, depende dos seus dependentes que, melhor do que ele, acompanhando-o, fazem o que ele deveria fazer. Sendo, no entanto, também homem ambicioso, não só traiu, por cupidez, quem o beneficiou, como evita beneficiar todos quantos o servem, de modo a economizar. Totalmente inábil no discurso social, incapaz no desempenho diplomático, «Don Estevan» é excluído do trato com as elites, lidando com os que o servem como iguais e fazendo declarações em que ridiculamente expõe todas as suas fraquezas, mesmo quando pretende defender-se. Eis Joam Viegas de Portocarreiro, ou «Don Estevan», que Sancho II quis ver na cadeira do arcebispado de Braga, num tempo em que necessitava de ali ter um aliado; o mesmo Joam Viegas que presenciou a assinatura do Juramento de Paris, acreditando no cumprimento do que Afonso III nele prometia para chegar ao poder; e que não tardou muito a descobrir o reduzido valor das promessas de Afonso III.

Feito o retrato, sobram questões relacionadas com o tempo, o lugar, o modo e o objetivo da sátira. A análise interna dos textos levou-me a identificar a cantiga Don Estevan que lhi non gradecedes, de Joam Soares Coelho, como a cantiga inaugural do conjunto, onde se propõe a substituição do nome do visado, a partir da justificação, dada na própria cantiga, de que Joam Viegas necessitava de um nome à altura do cargo para o qual tinha sido eleito. Este nome seria o de Estêvão Soares, «Don Estevan», anterior Arcebispo, de alcunha herdada, Torto. Nesta cantiga, a sátira atinge o próprio rei Sancho II, cujo interesse na eleição tê-la-á 
determinado. É de resto esta a razão por que Joam Soares Coelho, vassalo de Fernando infante de Serpa, participa neste conjunto satírico iniciando-o, em 1244, ano da eleição do arcebispo de Braga. Nesta data, o infante, que fora um próximo aliado de Sancho II, tinha-se então já tornado vassalo da Santa Sé, que chegara a considerá-lo para substituir o irmão no trono, e era já próximo dos aliados de Afonso no reino. Mas Fernando assume intermitentemente a tenência de Tarouca e na qualidade de tenente deverá frequentar a corte, nos tempos conturbados que precedem a deposição do Rei.

Terá sido uma ousadia apresentar na corte, em 1244, após a eleição de Joam Viegas de Portocarreiro, a cantiga Don Estevan que Thi non gradecedes, onde o Rei é criticado por influenciar a eleição de figura incapaz e dependente de inferiores para lugar ocupado, anteriormente, por pessoa como Estêvão Soares. Terá sido uma ousadia retratar o arcebispo de Braga como um idiota dependente e inapto. Sobretudo em tempos perigosos como os do «tumulto e guerra», em que o perigo de assalto, roubo e assassínio espreitava, já não só fora das cidades, mas mesmo dentro de muros. $\mathrm{O}$ grau elevado de opacidade da cantiga poderá justificar-se pela ousadia e ter sido uma medida de prevenção. Na verdade, não vejo em que outro espaço, além da corte, poderia esta sátira aguçada cumprir os objetivos políticos que tem.

As duas cantigas que creio seguirem-se - Don Estevan diz que desamor, de Vuitorom, e Don Estevan, eu eiri comi, de Tenoiro - são ambas anteriores à saída de Sancho II do reino e posteriores à entrada de Afonso III. Dada esta circunstância e o facto de Sancho II se ter refugiado em Coimbra, enquanto Afonso III fez principalmente de Leiria o seu quartel-general, impõem-se questões sobre onde terão sido apresentadas as cantigas e com que objetivos argumentativos.

Em nenhuma das duas há já, claro, crítica nenhuma a Sancho II, quanto mais não fosse porque este se convertera entretanto na principal vítima da eleição que patrocinara. Vuitorom e Tenoiro são ambos de pequena nobreza dependente, próximos do infante Alfonso de Castela, que entre os últimos dias de $1246 \mathrm{e}$ março de 1247, se esforça por reunir apoios em torno da causa de Sancho, participa numa ação militar em Leiria e, por fim, retira-se com Sancho II para Castela. As duas cantigas que os dois trovadores fazem, a de Tenoiro antes de março de 1247, a de Vuitorom já depois de 1247, mas ainda antes da morte de Sancho II, inscrevem-se provavelmente na ação de propaganda orquestrada por Alfonso de Castela com o objetivo de obter apoios, sem os quais a sua ação isolada seria vã, como se verificou ter sido de facto ${ }^{1}$. A cantiga de Tenoiro, inflada de esperança,

1 Marcenaro (2014: 38 ) considera haver poucas cantigas propagandísticas na Lírica Galego-Portuguesa («ben poche cantigas satiriche assumono l'aspetto propagandistico, al limite pamphlettistico, di molti sirventesi occitani»), embora considere também que o desconhecimento da efetiva relação de muitas com os respetivos contextos possa reservar-nos algumas surpresas. 
vai cheia de promessas de prosperidade, mas também de castigo aos traidores que serão afastados da mesa farta dos novos tempos. A cantiga de Vuitorom orienta-se mais para a denúncia descredibilizante, o que provavelmente procurava atingir a arma que o arcebispo de Braga usava então sem parcimónia: a excomunhão. Acusar o Arcebispo de ter traído por cupidez, de não ser suficientemente inteligente para ver que seria enganado pelo Conde inscrever-se-ia numa estratégia para reduzir o medo dele e, consequentemente, aumentar a possibilidade de reunir apoios em torno de Sancho II. Tendo esta cantiga sido composta após a saída de Sancho II do reino, é possível que o Rei tenha inicialmente pensado numa retirada temporária. Nesta eventualidade otimista, alguns trovadores poderão ter ficado ainda algum tempo com a incumbência de usar a sátira para preparar o terreno, com vista a um retorno que nunca aconteceu. Em qualquer caso, sendo este o objetivo, o lugar de performace mais provável destas cantigas terão sido as casas onde houvesse esperança de obter tais apoios, longe portanto dos apoiantes do Conde, longe das cidades que lhe abriram os braços.

Todas as restantes composições deverão ser de um tempo diferente, marcado pela morte de Sancho II em janeiro de 1248 e pela instituição de um novo poder e uma nova ordem. Também pela súbita abertura de oportunidades na corte portuguesa, a que a pequena nobreza dependente estaria naturalmente muito atenta. É possível igualmente que estas cantigas tenham sido compostas antes da morte de mestre Vicente, bispo da Guarda e antigo chanceler de Sancho II, em setembro do mesmo ano, pelo que terão sido criadas durante o ano de 1248 , num período máximo de oito meses.

Tudo indica que tenha sido mais uma vez Joam Soares Coelho a voltar à carga contra o arcebispo de Braga, uma vez que as cantigas dos outros trovadores, de uma forma ou de outra, recuperam aspetos da cantiga de Joam Soares Coelho Don Estevan fez sa partiçon. O infante de Serpa morrera em 1246 e, em janeiro de 1248, Joam Soares Coelho já se aproximara certamente do círculo próximo de Afonso III. Tanto que, em novembro de 1248, já consta como conselheiro na ata da primeira reunião plenária da cúria, em Ourém (VENTURA 1992: 71, n. 3). O objetivo argumentativo na segunda cantiga de escárnio contra «Don Estevan», assinada por Joam Soares Coelho, é certamente o do novo rei. Compreende-se: Afonso III comprometera-se com o clero em Paris, mas, chegado ao trono, precisava de se afastar de companhias clericais demasiado exigentes e de reduzida confiança, precisava de diminuir a pressão para o cumprimento, até porque não teria propriamente intenções de cumprir. A descredibilização do arcebispo de Braga servia estes objetivos e tinha até já começado anteriormente, com ataques em prol da honra do irmão Sancho II, o que contribuia bastante para salvar a face do novo Rei nos novos ataques ao Arcebispo. Coelho está portanto ao serviço de Afonso III na descre- 
dibilização de Joam Viegas, que ajudará o Rei a preparar o incumprimento. Mas um só trovador não faz esta primavera. Outros já tinham «entrado na roda» e estariam ainda em Portugal: Tenoiro e Vuitorom; outro poderia entrar: Queimado. Aliciados por Afonso III, ou por Coelho ao serviço de Afonso III, não desdenharam os primeiros de fazer o que já tinham feito: atacar o arcebispo de Braga nas suas imensas fraquezas. Após a morte de Sancho II, só restavam os interesses de Afonso III e estes não eram coincidentes com os do arcebispo de Braga, a partir do momento em que se sentou no trono. De resto, a face dos trovadores de Alfonso de Castela esteve sempre salva, uma vez que nunca tiveram de mudar de posição em relação a «Don Estevan»: contra ele tinham estado antes da morte de Sancho II, contra ele permaneceram depois.

Em todo o caso, há, na composição das cantigas, indícios de que os trovadores não alinham todos pelo mesmo diapasão, embora a tensão entre eles seja aparentemente nula. Veja-se, por exemplo, o que acontece no jogo com o verbo «ver». Coelho inaugura-o na cantiga Don Estevan que lhi non gradecedes, certamente devido à alcunha Torto (cego de um olho), atribuindo-lhe o sentido metafórico de «entender», que aliás mantém na segunda cantiga. Vuitorom e Tenoiro, autores claramente muito próximos neste conjunto satírico, adotam o jogo, nas cantigas anteriores a 1248, embora lhe atribuam o sentido de «receber benefício». Nas cantigas posteriores a janeiro de 1248, porém, rejeitam este jogo: Tenoiro usa o próprio adjetivo «torto» e Vuitorom concentra-se na expressão «catar por», além de ambos desenvolverem especialmente a vertente temática da sanha. Procurando destacar mais, nestas cantigas, o sentido de «injusto» que «torto» também tem, Tenoiro e Vuitorom parecem esforçar-se por variar na abordagem à crítica a «Don Estevan», especialmente depois de janeiro de 1248.

Queimado é mais transversal. Participa no conjunto satírico só a partir de janeiro de 1248 e, num primeiro momento (Don Estevan, en grand'entençon), em diálogo estreito com as cantigas de Coelho. $\mathrm{O}$ jogo com o verbo «ver» tem aqui ainda o mesmo sentido que lhe atribuiu Joam Soares: «entender para lá das evidências». Mas, depois (Don Marco, vej'eu muito queixar), Queimado demarca-se de Coelho, experimenta o ângulo da sanha, de Vuitorom e Tenoiro, embora com discrição, e, no jogo com o verbo «ver», atribui-lhe um sentido novo: visitar.

Há, porém, no conjunto satírico, algumas ideias que são exclusivas de alguns trovadores, outras que são transversais a todos e outras ainda que unem apenas dois trovadores. A acusação de cupidez associada à traição, que encontramos em ambas as cantigas de Vuitorom, é exclusiva deste trovador, embora Tenoiro na cantiga do jantar (Don Estevan, eu eiri comi) lhe dê certa continuidade com uma abordagem marcadamente imagética, como também é a da sua segunda cantiga (Don Estevan achei noutro dia), onde nos mostra três vezes a mesma 
imagem (o vilão em marcha, seguido de «Don Estevan»), interpretada de formas diferentes.

A inabilidade para se defender, que encontramos demonstrada na cantiga Don Estevan, en grand'entençon, de Queimado, encontra-se também tratada na de Tenoiro, Don Estevan achei noutro dia. A acusação de sanha desproporcionada destaca-se nas duas cantigas de Tenoiro e Vuitorom, posteriores a janeiro de 1248 e, embora mais subtilmente, também a encontramos em Don Marco, vejeu muito queixar, de Queimado. As acusações de inadaptação, incapacidade de entendimento e diplomacia, de dependência de dependentes são mais transversais a todas as cantigas, com poucas exceções.

Sentem-se alianças e afastamentos entre os trovadores que creio terem ido além da política. Recordo que, no conjunto satírico em torno da Ama, Joam Soares Coelho acusa Vuitorom de lhe roubar composições e de não ter qualidade para julgar compositores. Por seu lado, Vuitorom declara-se superior a Coelho na arte de trovar (CORREIA 2017: 82-86). As pontes detetadas entre os textos não serão certamente alheias a estas picardias. Nem talvez as picardias, alheias à luta por um lugar na nova ordem do mundo, posterior à guerra civil. 



\section{Enquadramento histórico}

A contextualização histórica que farei, neste capítulo, começará por um breve perfil e percurso dos dois arcebispos a que os trovadores aludem no conjunto satírico estudado (Estêvão Soares e Joam Viegas de Portocarreiro), sem omitir um breve perfil e percurso do Arcebispo que governou a arquidiocese de Braga entre os dois (Silvestre Godinho). Deverá estar precisamente no que aproxima e afasta estes três homens o que levou os trovadores a adotar o nome do primeiro e não do segundo para substituir o nome do terceiro. Em todo o caso, traçar-lhes o perfil e o percurso será uma forma de assumir um ponto de vista sobre os acontecimentos que contextualizam a composição das cantigas aqui estudadas.

Concentrar-me-ei de seguida numa breve caraterização do espaço urbano e das oligarquias que nele se desenvolviam, na época em que as cantigas estudadas foram compostas. As razões desta atenção às cidades prendem-se com a importância que assumem no caminho que levou à guerra civil de 1245-1248 e com o facto de serem o lugar de desenvolvimento de uma oligarquia influente na relação geral de forças da sociedade medieval, que as cantigas refletem. Mas há também duas razões mais concretas: a referência, no conjunto das cantigas editadas e estudadas, a diversos topónimos de cidades, território de bispos e arcebispos por excelência; e o facto de serem mencionados ou aludidos estatutos sociais cuja relação com a cidade é importante. Sem compreendermos o contexto urbano medieval, o sentido fino de muitas referências e alusões nestas cantigas poderiam, por esta razão, escapar-nos. Ou dito de forma inversa, tendo mais presente o contexto urbano medieval e a dinâmica social que ele impõe, conseguiremos compreender melhor as alusões e referências das cantigas que o tomam como pano de fundo.

Os acontecimentos que conduziram à deposição de Sancho II serão depois recordados, neste capítulo de enquadramento, em traços largos, mas abrangendo os dez últimos anos do reinado, aqueles em que a violência se agravou e aqueles a que creio haver alusão numa das cantigas de Mem Rodrigues Tenoiro (Don Estevan, eu eiri comi).

Finalmente, recordarei os elementos biográficos conhecidos dos trovadores envolvidos na sátira a «Don Estevan». 


\section{Estêvão Soares, arcebispo de Braga}

Sancho II foi dado em criação, conforme o costume medieval, a Martim Fernandes de Riba de Vizela e sua mulher, Estevainha Soares ${ }^{1}$. Pelas habituais alianças matrimoniais, o casal dispunha de um património considerável de relações ao mais alto nível do poder. Martim Fernandes de Riba de Vizela descendia de família estabelecida em Coimbra desde o século XII e pertencente à elite desta cidade. A ama, Estevainha Soares, era sobrinha-neta de D. Gonçalo de Sousa. Esta ligação aos Sousa, a família mais prestigiada e uma das mais poderosas do reino, pelo menos fora das cidades ${ }^{2}$, terá influenciado o casamento do irmão de Martim Fernandes, Joam Fernandes, alcaide de Coimbra, com uma filha da família de Sousa e, mais importante do que isto, terá impulsionado a ocupação de cargos na corte pelos Riba de Vizela, que antes eram ocupados pelos Sousa. A estratégia de ascensão socioeconómica dos Riba de Vizela é de tal forma eficaz que acabarão por lograr a proeza de iniciar o século XIII como simples cavaleiros, e acabá-lo como condes (FERNANDES 2010: 45).

Estevainha Soares e Estêvão Soares foram dois dos três filhos do casal Soeiro Pires Torto ${ }^{3}$ e Fruilhe Veegas. A terceira filha, mencionada nos Livros de Linha-

H. Fernandes expressa dúvidas sobre ter Estevainha sido a «verdadeira» ama de Sancho II, por um neto dela ser designado colaço do Rei num documento. Considerando que a função de uma ama nobre era a de educar, não a de amamentar (exceto em casos excecionais), faz perfeito sentido que D. Estevainha tivesse criado, ou seja, educado D. Sancho com o neto, procurando dar ao neto o melhor colaço possível. Sendo esta a função, faz também sentido que as Inquirições de 1220 refiram, com o verbo no presente, como nota H. Fernandes, a criação do príncipe e a sua ama, quando este tem já 10 anos $(2010: 46,47,49)$. Vejam-se outros casos elucidativos de criação em Correia (2017: 135-146). E note-se ainda que o Livro de doações de Tarouca, fonte da informação sobre os amos de Sancho II, identifica Martim Fernandes e Estevainha Soares como nutritores de Sancho (FERNANDES 2010: 49). Este termo que, à letra, poderia apenas designar a mulher; sendo usado para o casal, aponta claramente para a função de educadores. De resto, a mesma formulação é usada a propósito da educação de religiosos em instituições religiosas. Mestre Silvestre, jurista e arcebispo de Braga, refere-se assim, no seu testamento, ao local onde foi educado: «Item casale meum quod emi per Johannem Munionis in Baronceli mando dari sancto Pelagio de Pousada, ubi fui nutritus per trienium et legi psalterium» (CosTA 1963: 15).

2 «Ao país senhorial não se opõe ainda o país do rei, como acontecerá muito claramente em Trezentos, mas o país das cidades e das oligarquias urbanas que as governam. Quanto ao espaço de intervenção da nobreza tradicional ele é, declaradamente, não urbano. E os Sousãos mantêm, nesses círculos, um primeiro lugar» (FERNANDES 2010: 144).

3 Na edição dos Livros de Linhagens, J. Mattoso dá conta de oscilações no registo deste nome e no próprio entendimento, editando «Torta», «Tortas» ou, no índice de «Apelidos, Alcunhas e Nomes de Família», «Torto», considerando-o aqui a mesma alcunha usada por João Anes de Biscaia, com o sentido, portanto, de homem zarolho, como explicado no Livro de linhagens do conde D. Pedro: «E fez em esta dona Maria o ifante dom Joham ũu filho que houve nome dom Joham, e foi cego de ũu olho, e por esto lhe chamarom dom Joham, o Torto.» (MATTOSO 1980, vol. II/1, p. 144) De acordo com o costume, Soeiro Pires é também referido com a alcunha do pai, que se chamou Pero Paaez Escacha (ibidem, vol. II/2, p. 97). Este mesmo costume, que terá levado a atribuir às filhas de Soeiro os nomes de Estevainha Soares Torta e Teresa Soares Torta (Torto no feminino), poderá ter influenciado a grafia da alcunha do póprio Soeiro. 
gens, Teresa Soares, foi mãe do famoso Tenreiro, satirizado por cobardia nos cancioneiros. Conforme o costume, todos os filhos de Soeiro Pires terão herdado a alcunha do pai. Estêvão Soares, terá sido portanto conhecido também por Estêvão Soares Torto. Ou, pelo menos, poderia ser assim identificado por quem conhecesse a alcunha do pai. Tanto nos Livros de Linhagens, quanto na documentação, o Arcebispo é tratado por D. Estêvão Soares ou, mais frequentemente, apenas por D. Estêvão:

«dom Estevam Soarez» (MATTOSO 1980, vol. II/2, p. 97)

«dom Estevão» (ibidem, vol. I, p. 41, 43)

Notum fit omnibus tã praesentibus, quam futuris per hanc chartã. Ego Adfunsus Dei gratia Rex Legionis, \& Galletiae, concedo Ecclesiae Bracharensi, \& vobis dono Stephano eiusdẽ Ecclesiae Archiepiscopo, \& vestro Capitulo, illa villã deEruedede (Carta de doação de Ervededo por Afonso IX, CUNHA 1634: 97)

Correndo demanda os tẽpos passados entre o Senhor Rey D. Affonso II de Portugal de hũa parte, \& o senhor Arcebispo de Braga D. Esteuão da outra, sobre, \& por rezão (Escritura de acordo entre Sancho e D. Estêvão, ibidem, p. 103).

Quando Martim Fernandes de Riba de Vizela e Estevainha Soares assumem a educação de Sancho II, o casal tem já duas filhas crescidas: Mor Martins, barregã de Afonso II, que virá depois a casar com Ponço Afonso de Baião (FERNANDES 2010: 123); e Teresa Martins, mãe de Martim Martins, que, sendo neto de Estevainha, será criado com Sancho tornando-se colaço deste e, mais tarde, mestre da Ordem do Templo (ibidem, p. 160).

$\mathrm{O}$ amo de Sancho II morre em 1212, quando o príncipe não contava mais de dois anos, mas Estevainha sobrevive-lhe até 1229 e assume as rédeas familiares. A morte de Martim Fernandes em tenra idade de Sancho II, no entanto, deixou vaga uma função educativa que a ama não poderia ter cumprido, por estar reservada aos homens. Sendo necessário delegá-la, é possível, como supõem J. Mattoso e A. Sousa ${ }^{4}$, que a tenha assumido Estêvão Soares, o irmão de Este- 
vainha, que em 1212 era ainda mestre-escola na Sé de Coimbra (CunHA 1634: 91), cidade da origem familiar ${ }^{5}$. No ano seguinte, no entanto, esta figura dará um passo importante na carreira eclesiástica sendo eleito pelo cabido bracarense para ocupar a única arquidiocese do reino. Ou seja, a posição eclesiástica mais importante e rendível que poderia ambicionar (FERNANDES 2010: 43-44). Honório III descreve-o assim: «zelador da Ecclesiastica liberdade, abrazado no zelo da justiça, \& que não sabia, nem queria respeitar maes aos homens, q̃a Deos: varaõ eminente nas letras, \& santidade» (CUNHA 1634: 91).

A tal eleição pelo cabido bracarense do mestre-escola da sé de Coimbra, irmão da ama do príncipe herdeiro e talvez substituto do amo, é provável que não tenha sido alheio o favor do Rei. Tanto mais que o novo Arcebispo era também tio da barregã de Afonso II: Mor Martins, filha de Estevainha Soares. Na contestação que Estêvão enfrenta, logo depois da eleição, haverá talvez indício do mal-estar no cabido: «Auida a Confirmação, Sagração, \& pallio, começou logo o Arcebispo, como zeloso, que era, a entender com alguns Priores de seu Arcebispado, assi seculares, como regulares, que lhe não queriaõ obedecer» (CUNHA 1634: 91).

Cabe, neste ponto, abrirmos um parêntese sobre a eleição de bispos e arcebispos. Os primeiros reis portugueses chamaram a eles a nomeação dos seus bispos, seguindo aliás a tradição visigótica (BARROS 1945-1954, vol. 2, p. 46-49). O movimento para entregar aos cabidos o exclusivo da eleição dos bispos começou no século XII, mas só quando a eleição do Papa passou a fazer-se pelo colégio dos cardiais, excluindo o clero e o povo, a ideia de replicar o método na eleição dos bispos começou a fazer lento caminho. $\mathrm{O}$ cânon ficou por fim estabelecido no concílio de Latrão, em 1215 (ibidem, p. 50). Em Portugal, no entanto, só na segunda metade do século XIII as eleições capitulares se generalizaram (ibidem, p. 52). Mas mesmo estas eleições não se faziam sem a intervenção do Rei:

A eleições capitulares correspondia da parte dos reis portuguezes o estylo de insinuarem a cabido a pessoa que devia eleger, e de serem elles tambem, como padroeiros de todas as sés do reino, que apresentavam o eleito para ser confirmado; e da existencia d'estas insinuações temos a prova até nas

que não fosse vassalo do Rei no sentido estrito. Assim se explicaria o papel que tomou nas duas concórdias com as infantas e consigo próprio, e que parecem significar a vitória do partido "senhorial", ao contrário, decerto, do que desejava o Rei falecido» (MATTOso e SousA 1993: 120).

5 H. Fernandes (2010: 132) também considera a possibilidade de o Arcebispo ter tido algum peso na criação de Sancho II, mas apenas indireto. Note-se que as funções do papa Inocêncio III não o impediram de assumir a educação do imperador Frederico II (ibidem, p. 171). 
allegações do clero queixando-se do procedimento do rei, que não negava o facto, mas apenas contestava em Roma o caracter de imposição que lhe queriam attribuir 6 .

Quando, em 1213, Estêvão Soares assume a arquidiocese de Braga, é provável portanto que o tenha devido, em grande medida, ao rei Afonso II, e aos familiares que, movendo-se na esfera doméstica do Rei, o terão influenciado. Passará também ele a frequentar assiduamente a corte, como faziam habitualmente os bispos que pouco se demoravam nas dioceses. A corte do Rei ou do Papa era a sua residência mais habitual ${ }^{7}$ e esta é também uma mudança assinalável para o antigo mestre-escola da Sé de Coimbra. A sujeição à hierarquia da Igreja é inquestionável para um ministro de topo como era um Bispo e mais ainda um metropolita, mas uma certa dependência do poder secular impunha-lhe a necessidade de jogar em dois tabuleiros, com a indispensável habilidade diplomática. Note-se que «em 1219 os bispos portugueses ainda se queixavam de os reis e os concelhos os impedirem de delimitar as paróquias como eles pretendiam» (MATTOsO 1992: 50).

Na semana santa de 1218, é ainda com generosidade que Afonso II trata Estêvão Soares, ao conceder-lhe as décimas de todos os rendimentos pertencentes aos direitos reais na arquidiocese de Braga (COSTA 1963: 48). Mas, em 1220, o Rei manda fazer Inquirições. E segundo sabemos por carta do papa Honório III, Afonso II teria imposto «pesadas colectas e outros avultados encargos às igrejas, catedrais e não catedrais, aos mosteiros, hospitais, casas da Ordem do Templo e outros lugares religiosos, bem como aos clérigos», além de que «revogara arbitràriamente as doações que antes havia feito às igrejas e pessoas eclesiásticas $>^{8}$. O objetivo do Rei, aconselhado pelos juristas que o rodeavam, seria o de conter o avanço das imunidades e do poder económico do clero, que, ao longo do

6 Barros (1945-1954, vol. 2, p. 53). Em 1225, Fernando III obrigava o bispo de Segóvia a sair da diocese, além de lhe confiscar os bens, por ter sido eleito sem o consentimento do Rei (ibidem, p. 55). A disputa entre o Rei e os bispos pela nomeação para as igrejas foi cerrada e deixou documentação diversa. Por exemplo, numa inquirição mandada fazer em 1233, reporta-se que o prior apresentado pelos paroquianos e clérigos da igreja de São Pedro de Ourém ao bispo de Évora recebeu deste a nomeação e do Rei o assentimento. Mas quando este prior morreu, outro prior foi dado pelo Rei (de manu regis), o que motivou a excomunhão pelo Bispo e interdição da igreja (FERNANDES 2010: 206).

7 Barros (1945-1954, vol. 2, p. 150). Este autor acrescenta: «Da permanência d'elle junto do monarcha se queixam os povos nas côrtes principiadas em Coimbra em 1472, reconhecendo D. Afonso V a justiça do clamor popular. Mas o facto era antigo e geral.» (ibidem, p. 151).

8 Costa (1963: 97). Nesta atitude vê Alexandre Herculano influência de mestre Vicente, opinião para que S. Costa (ibidem, p. 109) não encontra nenhuma prova documental. Pelo contrário, encontra provas de que mestre Vicente terá posteriormente ajudado a resolver a questão entre Afonso II e Estêvão Soares. H. Fernandes (2010: 54) considera que mestre Vicente e outros juristas que rodeavam Afonso II o influenciavam no sentido da necessidade de reduzir o poder e as isenções do clero, increvendo-se as Inquirições de 20 neste esforço. 
tempo, por negligência ou generosidade da coroa, se tinha ido apoderando de bens e benefícios alheios (FERNANDES 2010: 54).

As ligações de Estêvão Soares à domesticidade do Rei e a dívida contraída no momento da nomeação para a arquidiocese, com a consequente aproximação à corte e, dentro desta, ao círculo que lhe estava mais próximo, talvez tenham fomentado no monarca a expetativa de menos resistência ou mais lealdade, para usar vocabulário de um tipo de relação que, na verdade, o Rei não tinha com um clérigo. Ou talvez apesar de tudo tivesse, se considerarmos que o bispo de Coimbra, por exemplo, virá a preferir a lealdade ao Rei, quando ignora o interdito lançado pela Igreja sobre o reino.

Mas para esclarecermos melhor esta questão da expetativa de lealdade entre as duas hierarquias (a clerical e a militar), poderá ser elucidativo o caso do bispo do Porto, Pedro Salvadores, que tinha recebido em doação de D. Teresa, tia de Sancho II, o burgo do Porto e, portanto, pretendia exercer o direito de padroado na cidade, o que era contestado pelos cidadãos. A contenda envolve o Papa, que defende o Bispo; e o Rei, que defende os cidadãos. Na troca de acusações, Pedro Salvadores censura o Rei por abordar os cidadãos procurando aliciá-los, ou seja, ignorando «a hierarquia vassálica, dirigindo-se directamente aos vassalos do seu vassalo, o bispo do Porto» (ibidem, p. 202, 257). Também mestre Vicente, enquanto bispo de Idanha / Guarda, ao atribuir foral a Alter do Chão, reserva-se o privilégio de escolher os vizinhos, «sublinhando que os moradores deverão ser sempre bons vassalos seus e dos seus sucessores» (ibidem, p. 263).

Deste entendimento da situação se depreende que a visão feudo-vassálica das relações militares contaminou igualmente a visão das relações clericais e mesmo as relações transversais às duas ordens e às que estavam fora delas. Ou seja, os cidadãos eram vistos como vassalos do Bispo, e o Bispo como vassalo do Rei ${ }^{9}$. Necessariamente, as ideias de lealdade e de traição estarão igualmente associadas a esta noção de vassalidade.

Em 1220, o Arcebispo tivera já tempo de adaptar-se aos ambientes de corte, multiplicar redes de influência e apoio (ibidem, p. 43-44), além de consolidar o seu prestígio de diplomata e eclesiástico, certamente assente em património con-

«Junto a su empleo para designar a quienes habían contratado una relación vasallática que podríamos llamar feudal, difundió el término vasallo de manera extraordinaria su aplicación a muy diversos tipos de gentes en relación de dependencia de un señor. En primer término a algunos laicos o eclesiásticos de condición social no ínfima que recibían un prestimonio a cambio de la fidelidad vasallática y de ciertas obligaciones económicas. Y después, primero de modo frecuente y luego de modo continuo, para nombrar a los que podríamos calificar de súbditos - los habitantes en el reino para con el monarca y los moradores en tierras señoriales frente al señor - y se usó para nombrar incluso a los tributarios o colonos de los magnates laicos o eclesiásticos». (GRASSOTTI 1069: 69-70). 
siderável ${ }^{10}$. Demonstrara habilidade e força, em 1215, enfrentando a contestação apresentada pelo arcebispo de Toledo, Rodrigo Ximenes, «pessoa de grande authoridade, \& letras, \& muito valido do Sũmmo Pontifice, \& Reys de Castella, \& Leã̃» (CunHA 1634: 92), quanto ao estatuto de Braga como igreja Primaz da Espanha, em detrimento da de Toledo. Embora o Papa nunca tenha chegado a tomar uma decisão sobre este assunto, o facto de não o ter feito e de ter deixado ficar tudo como estava constituiu uma vitória para o arcebispo D. Estêvão (ibidem, p. 92-93).

Já depois deste episódio, em 1219, assinará uma doação na qualidade de «Legado da Se Apostolica» (ibidem, p. 96). Também a participação como mediador no acordo de Boronal, entre a coroa de Portugal e a de Leão, lhe tinha valido a doação, pelo rei Afonso IX de Leão, do couto de Ervededo (dentro da Tenência de Martin Sanches, irmão do Rei) (FERNANDES 2010: 55), no mesmo ano de 1219 (CunHA 1634: 96).

O acordo que Sancho II fará com as tias, após a morte do pai, tornará evidente a aliança, mais ou menos conjuntural, entre o Arcebispo e as «rainhas» Teresa, Sancha e Mafalda, na prolongada contenda que as tinha oposto ao irmão, Afonso II (FERNANDES 2010: 115).

Ora, quando Afonso II age contra os direitos da Igreja, como descrito por Honório III, o Arcebispo, que era, recorde-se, tio da barregã do Rei, facto que não terá sido de somenos importância na ascensão de Estêvão, ousa chamar o Rei à razão, apontando, ainda segundo Honório III, o dedo precisamente à infidelidade do Rei: «...debita libertate aliasque mores suos in melius reformeret, quos enormiter deformarat adulterinos amplexus coniugalibus quasi publice preferendo... $\gg^{11}$.

Afonso reagiu com violência extrema, destruindo os bens do Arcebispo e usando, nestes atos, o braço armado dos concelhos de Coimbra e Guimarães. Ou seja, sob as ordens de cavaleiros vassalos do Rei (Gil Vasques), são cidadãos, ou vilões, que destroem o património do arcebispo de Braga. D. Estêvão vê-se

10 Estêvão Soares dá diversas demonstrações da importância dada à acumulação de riqueza. Numa carta que Honório III lhe escreve em 1216, o Papa ordena ao Arcebispo e ao cabido de Braga que nomeiem cónego o portador da dita carta e lhe estabeleçam uma pensão, para que tivesse com que viver, uma vez que tinha servido muitos anos naquela igreja. Em caso de recusa, o Papa ameaçava dar poder ao bispo de Lamego e aos abades de Tarouca e Salzedas para usarem contra eles de penas canónicas (CostA 1977: 117).

11 Costa (1963: 97). A visão sobre estes avisos dirigidos por D. Estêvão ao Rei diferem. R. Cunha é relativamente neutro: «Auisou a el Rey de seus excessos, \& da impiedade de seus ministros... » (CUNHA 1634: 99), Costa (1963: 97) é benigno: «As admoestações brandas e cheias de caridade do Arcebispo teriam provocado a ira de D. Afonso II». Já A. Herculano (1915: 116) tem a visão contrária: «Porventura a linguagem energica do metropolita houvera surtido o desejado effeito, se a violencia do seu caracter lhe permittira conter-se nos limites da prudencia. Passando a julgar os costumes do Rei, lançou-lhe em rosto os seus amores illicitos, accusando-o de preferir quasi sem rebuço o adulterio ao affecto conjugal.» 
então forçado a exilar-se em Roma, depois de excomungar o Rei e interditar o reino, castigos que o Papa confirma.

O sumo pontífice intervém a favor do arcebispo de Braga impondo aos sufragâneos de Braga uma côngrua para que ele pudesse viver condignamente enquanto no exílio. Insta depois repetidamente o Rei a reparar o mal feito, ameaçando expor o reino de Portugal à conquista dos príncipes e reis que quisessem conquistá-lo. Afonso II demora a ceder às pressões papais: o reino permaneceu interdito ${ }^{12}$, ele próprio excomungado e, entre julho de 1221 e agosto de 1222, os documentos reais não são confirmados pelo arcebispo de Braga (COSTA 1963: 88-89). Em 1222, estando vizinho da morte e por razões apenas conjeturáveis, mas que poderão prender-se com as ligações do Arcebispo a Afonso IX de Leão e com a ameaça que o Papa repete de expor o reino à conquista dos reis vizinhos (FERNANDES 2010: 132, 133), Afonso II cede à negociação, e a paz é por fim acordada.

Não ficam, no entanto, estabelecidos os termos exatos da reparação e, antes que tal aconteça, o Rei acabará por morrer em Santarém, em março de 1223. Será Sancho II a encarregar-se da tarefa de encontrar satisfação suficiente para contentar o arcebispo de Braga, irmão de Estevainha, a sua ama e, talvez também ele amo na prática, na medida em que poderá ter substituído o marido de Estevainha nesta função. Tal possibilidade justificaria, como considera J. Mattoso e A. Sousa (1993: 120), a generosidade e a facilidade das cedências que Sancho faz no acordo estabelecido com o arcebispo de Braga, para reparação dos agravos perpetrados pelo pai.

O acordo é assinado em junho de 1223, escassos três meses após a morte de Afonso II, em Coimbra, cidade de influência dos Riba de Vizela, perante a cúria reunida pelo Rei (FERNANDES 2010: 131). Sancho II cede em tudo: na cobrança de impostos e no exercício da justiça nos domínios episcopais; na oferta de um braço armado regulador, mas desinteressado, em defesa dos bens e das pessoas dos eclesiásticos, em limitar a aposentadoria aos nobres, em não se intrometer na justiça feita pelos bispos sobre os clérigos, mesmo em matérias laicas (ibidem, p. 135).

Numa segunda parte do mesmo acordo, Sancho II cede uma extraordinária soma de dinheiro a D. Estêvão, depauperando o tesouro real, já de si debilitado e ameaçado pelas cedências às «rainhas» e ao próprio Estêvão Soares, no que respeitava a matéria coletável:

O acordo de 23 pode surgir assim a uma outra luz que não a do simples ressarcimento dos prejuízos causados pelas violências régias anteriormente praticadas: a do esvaziamento do poder do rei através de uma debilitação extrema 1915: 149) e será admoestado por isso (COSTA 1963: 100). 
de um dos elementos que mais tinha contribuído para cimentar o trono dos três primeiros monarcas, o seu tesouro, enriquecido pelo saque da guerra de fronteira e que se revelava vital para assegurar a sua posição numa economia fortemente monetarizada como era a das principais cidades, as do Sul do reino, Coimbra, Santarém ou mesmo Lisboa (ibidem, p. 137).

É importante notar que esta cedência a Estêvão Soares não serviu de exemplo a outros casos clericais semelhantes. Por muito que tivesse havido tentativas neste sentido, Sancho II não fez cedências a nenhum outro prelado, além de ter continuado a tentar controlar os benefícios eclesiásticos, canalizando-os para a sua própria clientela e para o seu próprio debilitado tesouro (ibidem, p. 152). D. Estêvão foi, portanto, uma extraordinária exceção.

Os anos que se seguiram ao acordo foram de concórdia entre Sancho II e o arcebispo de Braga, mas, mais do que isto, foram marcados pelo afastamento dos Riba de Vizela e dos Sousa (ibidem, p. 170), de que D. Estêvão se afastara, embora thes devesse provavelmente apoio na eleição para Arcebispo. São também anos de aproximação dos Braganções ao Rei, apoiados por Afonso IX de Leão, de que D. Estêvão se aproximara igualmente.

É em provável concertação com Afonso IX que Sancho II avança para a conquista de Elvas, acompanhado do arcebispo de Braga (ibidem, p. 189). A campanha é um fracasso: a memória que dela ficou é de retirada, e abandono do Rei (ibidem, p. 192). Na sequência do desastre, em torno do Rei, os Braganções começam a dar novamente lugar aos Riba de Vizela, que regressam aos lugares de influência sobre a governação. D. Estêvão, no entanto, permanece entre a nova entourage (ibidem, p. 195), resistindo ao desaire, apesar do apoio dado a Afonso IX, aos Braganções e ao próprio empreendimento de Elvas. Poucos se poderiam gabar de tanto. D. Estêvão ficará até ao fim, sem notícia de conflitos, ao lado do Rei. Mesmo quando poderia ter tomado o partido da Igreja defendendo o bispo do Porto, seu sufragâneo, na contenda que o opôs a Sancho II, em 1226-1227, não o fez. Mais ainda: dos 6 mil morabitinos previstos no acordo de 1223, D. Estêvão deixou mil, que o Rei ainda lhe devia, em testamento a Sancho (ibidem, p. 203).

Entre a morte de D. Estêvão, em 1228, e a véspera da deposição de Sancho II, que coincide com a eleição de Joam Viegas de Portocarreiro para arcebispo de Braga, em 1244, na rede de cidades, a luta pelos rendimentos das igrejas vai-se paulatinamente agravando. São nela intervenientes e opositores os bispos, o Rei e, por vezes também, o clero regular, resultando numa oligarquização progressiva. No início, «dificilmente se poderá pensar, contudo, num conflito generalizado e numa situação de ingovernabilidade, como acontece a partir de $36 \mathrm{ou}$, pior ainda, uma guerra já não endémica mas aberta, declarada e organizada, como acontecerá entre 45 e 47» (ibidem, p. 208). 


\section{Mestre Silvestre Godinho, arcebispo de Braga}

O perfil do novo arcebispo de Braga pouco tem de parecido com o de D. Estêvão, a começar pela origem no concelho de Braga (COSTA 1963: 18), uma vez que terá nascido em S. Paio da Pousada em cuja escola paroquial terá sido educado (ibidem, p. 26), e pela ausência de ligações familiares ao círculo doméstico do Rei. No entanto, segundo S. Costa, já deverá ter sido ele o ocupar-se da questão entre Afonso II e as irmãs (ibidem, p. 48-49, 358), o que faz de mestre Silvestre um velho conhecido da coroa. Antes do grande conflito entre Afonso II e o arcebispo D. Estêvão Soares, o Rei faz-lhe uma última doação, em 1218, declarando que a faz por amor a vários mestres, e nomeia o deão de Lisboa, mestre Vicente, e o arcediago, mestre Silvestre, que deverá ser Silvestre Godinho. «De tudo isto se infere que mestre Silvestre era jurista excecional que se notabilizou não só nos litígios entre o Rei e suas irmãs, como noutras questões judiciais, civis e eclesiásticas, como indica a sobredita referência a dinheiros provenientes do seu ofício de advogado:... pro quinque milibus aureorum quos habebam de fructibus possessionum mearum et de aduocacione mea» (ibidem, p. 49).

A ligação a Braga, quando foi eleito, era antiga, uma vez que mestre Silvestre aparece na documentação como arcediago de Braga, desde 1217, e depois, em 1224, já é mencionado como deão de Braga. O cabido elege-o por unanimidade para Arcebispo, embora invalidamente devido a uma formalidade: os cónegos não registaram o escrutínio por escrito e não pediram o consentimento de Silvestre antes de o elegerem, razão pela qual o Papa anula a eleição. Em 1229, no entanto, considera-se no dever de nomear Silvestre, «homem de célebre fama e conhecida ciência» para Arcebispo, ordenando ao cabido (que o elegera porunanimidade) que o aceitasse. A consagração ocorre pelas próprias mãos do papa Gregório IX, em 1231 (ibidem, p. 51). Apesar da eleição irregular pelo cabido, não teve dificuldade em confirmá-la; não havendo também notícias de contestação. De resto, o Papa manteve-o junto dele até 1231 e enviou ao reino um emissário especial, o legado papal João Abbeville, cuja passagem pelo reino resultou num momentâneo reforço de unidade em torno de Sancho II e, consequentemente, num efémero reforço do seu poder. Durante a primeira metade da década de 30, quando Silvestre Godinho é arcebispo de Braga, os bispos do reino unem-se em torno de Sancho II, os conflitos urbanos acalmam-se, as ordens militares ocupam-se das conquistas que prestigiam o Rei (FERNANDES 2010: 227).

De resto, a relação com o Rei foi essencialmente pacífica e, mesmo nos momentos de tensão, a diplomacia acabou por se sobrepor. Logo no início do mandato, foi mestre Silvestre encarregado de punir o bispo de Coimbra e os clérigos que, durante o interdito, se tinham mantido fiéis ao Rei. Mestre Silvestre 
fê-lo, mas o velho bispo Pedro Soares não deixou de receber o devido amparo até ao fim da vida (COSTA 1963: 356, 187-195). Em 1236-1238, durante as desavenças com o Rei, que envolvem o papa Gregório IX e que conduzem à excomunhão de cavaleiros (ibidem, p. 366) e barões (ibidem, p. 369), bem como à admoestação de Sancho II, mestre Silvestre nunca atravessa o limite da excomunhão do Rei, o que favoreceu um rápido acordo com a coroa (ibidem, p. 377). Apesar de o Rei não ter cumprido as promessas feitas, não se registaram mais desentendimentos. Mestre Silvestre, falecido em Roma, em 1244, onde tinha chegado em 1241, em nada terá contribuído para a deposição de Sancho $\mathrm{II}^{13}$.

\section{Joam Viegas de Portocarreiro, arcebispo de Braga}

Logo após o desaparecimento de mestre Silvestre, em Roma, em 1244, é eleito Joam Viegas de Portocarreiro para arcebispo de Braga, documentado como chantre e prepósito em $1238 \mathrm{e}$, em 1244, como arcediago (VENTURA 1992: 760). Nascido numa família de cavaleiros e criado pelo anterior Arcebispo, mestre Silvestre Godinho ${ }^{14}$, o novo Arcebispo apresentava alguma carreira eclesiástica no momento da eleição, mas não era nem um reconhecido jurista como mestre Silvestre, nem tinha a ascendência familiar de D. Estêvão Soares, sobrinho-neto de D. Gonçalo de Sousa, além de mestre-escola em Coimbra. Depois dos arcebispos D. Estêvão Soares e mestre Silvestre, a eleição de Joam Viegas de Portocarreiro era uma queda abrupta em prestígio e conhecimento.

Mas no final de 1244, quando o cabido elege para o posto eclesiástico mais rendível, prestigiado e poderoso em Portugal, precisamente o lugar do único metropolita no País, Sancho II não estava em situação de não prestar a máxima atenção a tal eleição. Cada vez mais desamparado e acossado, o Rei não podia dar-se ao luxo de não exercer toda a influência que pudesse sobre o cabido, para colocar em Braga pessoa que lhe fosse favorável. É certo que a sua autori-

13 Costa (1963: 381). Não é esta a opinião de L. Ventura, que, porém, não a explica: «O arcebispo de Braga, D. Silvestre Godins, presente na cúria pontifícia em 1244, onde acabará por morrer, preparava há já algum tempo o ambiente para o afastamento de Sancho II. Anteriormente, na sua qualidade de mestre, fizera parte do círculo de eruditos da corte de Afonso II» (2006: 70) A mesma opinião parece ter A. R. Rocha, que também não a explica: «De facto, alguns destes eclesiásticos, concedendo o seu apoio a $\mathrm{D}$. Afonso, conde Bolonha, foram responsáveis pela preparação da deposição de D. Sancho junto do papa. Entre eles contavam-se o arcebispo de Braga, num primeiro momento, D. Silvestre Godinho, depois substituído por D. João Viegas de Portocarreiro [...]» (ROCHA 2013: 115).

14 R. Cunha (1634: 135) dá a entender que esta informação é fornecida no testamento do Arcebispo, quando este deixa ordens para que se faça aniversário pela alma de mestre Silvestre. Não obstante, em 1238, Joam Viegas envolve-se em contenda, juntamente com Mem Mendes, tesoureiro do Cabido de Braga, contra D. Silvestre a propósito da divisão de rendimentos (VENTURA 1992: 760). 
dade natural poderia, sobretudo junto do clero, estar depauperada, mas onde esta faltasse, não faltaria certamente a influência dos relatos de violência, a mando ou com o beneplácito do Rei, sobre membros do clero. Tenhamos presente que, segundo documentos pontifícios, o cabido foi constrangido por Sancho II para eleger mestre Paio e, depois dele, João Falberto, após a morte de D. Soeiro, bispo de Lisboa, em 1233 (CostA 1963: 273). Lembremos ainda que, pela mesma altura da eleição de Joam Viegas de Portocarreiro, Sancho II ainda tentou, com doações, colocar o bispo do Porto ao seu lado, o que, de resto, de nada lhe serviu (FERNANDES 2010: 235).

Tentemos, pois, ver Joam Viegas de Portocarreiro pelos olhos de Sancho II, quando, em fim de 1244, já se saberia cercado e procuraria, in extremis, rodear-se de gente em quem pudesse confiar, quer por serviços antes prestados quer pela expetativa de vir a ser recompensada, quer por ambas as razões.

Em Braga, quando Joam Viegas foi eleito, havia dois clérigos Portococarreiro primos direitos: Joam Viegas e Fernão Anes, respetivamente filhos dos irmãos Egas Henriques de Portocarreiro e Joam Henriques de Portocarreiro.

Os primos eram descendentes de família ligada à corte desde cedo, uma vez que «Raimundo Garcia, o primeiro indivíduo documentado da linhagem foi confirmante de diplomas régios entre 1129 e 1152, e foi genro de um alferes do Conde D. Henrique» (PIZARro 1997, vol. 2, p. 910). Também Egas Henriques, pai de Joam Viegas, está documentado em ligação à corte de Sancho o Velho, em 1187 (ibidem, p. 913). Quanto a Joam Henriques, a ligação é talvez mais peculiar, mas importa reconhecê-la. Em 1234 (dois anos antes de a derrocada ter começado para Sancho II, portanto), Joam Henriques foi sepultado num dos espaços funerários mais prestigiados e reservado a muito poucos, entre reis e ricos-homens: a real abadia de Alcobaça. Desconhecemos as razões de tamanha honra, mas ela não deixaria certamente de marcar positivamente a família próxima. Além disto, Joam Henriques é mencionado num documento, em 1209, como testemunha de compras feitas por Martim Fernandes de Riba de Vizela, família especialmente próxima de Sancho II (ibidem, p. 923). Um filho de Joam Henriques, Pero Anes, irmão portanto de Fernão Anes, um dos primos em Braga, foi tenente de Parada desde 1223 e aparece na corte a partir de 1237. Entre 1239 e 1240, participou nas campanhas militares de Sancho II: Mértola, Alfajar de Pena, Ayamonte e Cacela (ibidem, p. 929-930). A ligação à corte explica também as ligações patrimoniais da linhagem aos centros urbanos, como Coimbra e Santarém (ibidem, p. 911).

Para Sancho, o perfil dos Portocarreiro prometia fidelidade, naquele final de 1244, e entre os dois primos terá pesado talvez apenas o facto de Joam Viegas estar mais acima na hierarquia eclesiástica: era arcediago, enquanto Fernão Anes apenas cónego. Em todo o caso, tratando-se de família da média nobreza, 
Sancho II teria expetativas acrescidas de que o favor da pressão para a eleição tivesse retorno acrescido de fidelidade. Não é, no entanto, o que ocorre. Muito rapidamente, a posição de Joam Viegas define-se a favor de Afonso III: é ele a principal figura eclesiástica diante da qual, em Paris, em setembro de 1245, Afonso jura tudo o que lhe pedem para chegar ao poder - e não cumprirá. Será ele a escrever, com o bispo de Coimbra, aos «Guardiães de São Francisco da Guarda, \& Couilham» ameaçando-os de excomunhão se ajudassem as tropas do príncipe Alfonso castelhano, que se apressa a vir socorrer Sancho, e se não desistissem de resistir ao novo governador de Portugal (CUNHA 1634: 127-128).

Outro irmão do arcebispo de Braga, Raimundo Viegas, vassalo da «rainha» D. Teresa, irmã de Afonso II, será o famoso raptor da rainha Mecía Lopes de Haro (PIZARRO 1997, vol. 2, p. 917), que, procurando impedir qualquer possibilidade de descendência legítima, pretendia garantir que, à morte do Rei, sucederia o governador imposto pelo Papa, futuro Afonso III.

No Juramento de Paris, está também o cavaleiro Gomes Viegas, um dos irmãos de Joam Viegas (CUNHA 1634: 123; VENTURA 2006: 70), precisamente o que, paradoxalmente, é dado como protagonista da lenda do peixe no cerco de Celorico da Beira (ventura 1992: 762) e, portanto, como defensor de Sancho II. A Crónica de 1419 atribui, no entanto, o protagonismo da lenda a Fernão Rodrigues Pacheco ${ }^{15}$, assim como R. Cunha (1634: 129), que refere um privilégio dado, em 1246, por Sancho II à vila de Celorico da Beira. Neste documento, o Rei refere a defesa da vila por meio de engano, na circunstância de cerco, atribuindo a defesa a Fernão Rodrigues Pacheco. Por esta razão, teria entregado a alcaidaria ao referido vassalo. Na mesma carta de privilégio, menciona o papel do arcebispo de Braga, Joam Viegas, que durante o cerco se teria mantido lançando maldições e excomunhões sobre os cercados. Tem esta carta de privilégio o interesse acrescido de a confirmar a rainha Mecía e também D. Pero Anes, provavelmente D. Pero Anes de Portocarreiro, o tenente de Parada, que estaria junto do Rei, no exílio (ibidem) e terá atravessado a guerra civil mantendo-se fiel a Sancho II $^{16}$.

15 Teria enganado Afonso sobre a real quantidade de mantimentos existente no castelo cercado, ao servir-lhe uma truta cozinhada, que uma ave teria deixado cair dentro dos muros do castelo, onde já se morria de fome.

16 R. Cunha diz ter obtido este privilégio da «maõ de Luiz Ferreira deAzeuedo, qffoi Guarda mòr da Torre do Tõbo, pessoa taõ conhecida por sua rara erudição, nas antiguidades deste Reyno, certificandonos a mandara lançar naquelle Archiuo elRey D. Ioaõ o II. no tẽpo, que elRey D. Manoel, sendo ainda Duque de Beja, daua aquella sua villa a D. Diogo da Sylua seu Ayo, \& primeiro Conde, que depoes foi de Portalegre» (CUNHA 1634: 130). J. Pizarro duvida da fidelidade de Pero Anes a Sancho II por o encontrar entre os conselheiros de Afonso III em 1251 (1997, vol. 2, p. 930). No entanto, após a morte de Sancho II em 1248, esta não foi uma situação rara e terá mesmo feito parte da estratégia de pacificação do novo Rei. Vários dos nobres que figuram no testamento feito por Sancho II no exílio toledano em 1248 foram depois integrados na rede vassálica de Afonso III. É o caso de Gil Martins de Riba de Vizela, que se tornará mordomo-mor; de 
Se assim foi, portanto, durante o conflito, e apesar da recente eleição de Joam Viegas para a posição muito privilegiada de arcebispo de Braga, à qual não é provável ter sido alheia a pressão do Rei, os Portocarreiro dividem-se em dois partidos: os filhos de Egas Henriques de Portocarreiro assumem o partido do Conde, e os filhos de Joam Henriques de Portocarreiro assumem o partido de Sancho II.

Paradoxalmente (ou talvez não), após a morte de Sancho II, terão mais sucesso relativo junto de Afonso III os descendentes de Joam Henriques do que os de Egas Henriques: Fernão Anes, que já era cónego em Braga aquando da eleição de Joam Viegas, tornar-se-á deão e conselheiro de Afonso III, além de notário de Alfonso X (PIZARRo 1997, vol. 2, p. 923); Martim Pires, neto de Joam Henriques (e filho de Pero Anes) será cónego de Braga e privado de Afonso III, que o escolherá para aio do príncipe Afonso (ibidem, p. 934-35). O próprio Pero Anes integrará o grupo dos conselheiros régios (ibidem, p. 929-930).

Em todo o caso, como é sublinhado pelos historiadores, os Portocarreiro, ao contrário de outras linhagens da nobreza média que alcançaram, em situação semelhante, ascensão assinalável, não o conseguiram: «Mas, ao contrário dos Briteiros ou dos Nóbregas-Aboins, os Portocarreiros não beneficiaram do mesmo favor régio que elevou aqueles à rico-homia. Dir-se-ia mesmo que, com exceção de algumas carreiras eclesiásticas, a entronização do Bolonhês ditaria, a breve trecho, o afastamento da linhagem dos assuntos políticos» (ibidem, p. 910).

A desconfiança de Afonso III ter-se-á justificado pela traição do ramo de Egas Henriques, especialmente do arcebispo Joam Viegas. A traição de um Arcebispo cuja eleição Sancho II terá apoiado, e de quem Afonso III se afastou também tão depressa quanto pôde. Mas a cisão dentro da linhagem terá igualmente sido vista como uma traição à própria família ${ }^{17} \mathrm{e}$, neste caso, o percurso dos dois ramos e o relativo acolhimento no círculo mais próximo do Rei deixam claro qual deles foi visto como desprezível ${ }^{18}$.

Em todo o caso, é importante sublinhar que, nem mesmo na hierarquia da Igreja, Joam Viegas conseguiu impor a sua autoridade. Em 1252, Inocêncio IV

Fernão Fenandes Cogominho; de Egas Lourenço da Cunha e Martim Lourenço da Cunha; de Estêvão Peres Espinhel (FERNANDES 2010: 24). Não há, em todo o caso, nenhum indício de que o tenente de Parada tenha apoiado Afonso III antes da morte de Sancho II.

17 A importância do posicionamento familiar é considerada fundamental por R. Oliveira no momento de fazer uma opção, o que não acontece no caso dos Portocarreiro: «na hora das opções perante a adesão ao poder régio ou ao poder papal, este encarnado pelo conde de Boulogne, seria o posicionamento da linhagem no quadro da fractura política verificada que acabaria por ditar a integração num ou noutro bando» (OLIVEIRA 2006: 234).

18 L. Ventura põe a hipótese de uma homenagem de Afonso III no túmulo de D. Tibúrcio, bispo de Coimbra (2006: 149). Considerando que a este bispo e ao arcebispo de Braga ficou o Rei a dever o essencial das condições para a tomada do trono, o contraste entre esta homenagem e a memória que ficou das relações com o Arcebispo é assinalável. 
vê-se obrigado a enviar o deão de Zamora decidir o preito que corre entre o Arcebispo e os reitores de várias igrejas, por lhe recusarem estes a procuração devida por visitação («procurationes ratione visitationis sibi debitas ei contra justiciam denegant exhibere»). Em 1253, o Papa volta a ter de socorrer o Arcebispo, ordenando ao deão de Zamora que decida novo preito entre Joam Viegas e os reitores de várias igrejas que lhe recusam o sinodático e outros direitos episcopais. E, mais uma vez, no ano seguinte, em 1254, o Papa tem de intervir de igual modo, porque $\ll$ os abades e reitores de diversos mosteiros e igrejas se recusavam a pagar a terça parte dos direitos funerários devidos pelos não paroquianos que ali fossem sepultados.» Desta vez, o Papa desce na hierarquia para escolher o emissário: em vez de enviar o deão de Zamora para resolver a questão, recorre ao arcediago de Santarém e chantre de Lisboa (COSTA 1959, vol. 2, p. 463-464).

Encarregue, juntamente com o bispo de Coimbra, de executar o mandato pontifício de passar o reino de Portugal para as mãos do conde de Bolonha, Joam Viegas esforça-se por se manter, após a morte de Sancho II, próximo do novo Rei e da corte. Em março de 1250, está com Afonso III em Faro no esforço de conquista do Algarve, onde confirma uma doação (CUNHA 1634: 131). Em agosto, está com o Rei em Coimbra, onde confirma outra doação (ibidem, p. 132).

Mas logo nas Cortes de Guimarães, ocorridas em junho de 1250, o clero se manifesta insatisfeito com quem tinham colocado no poder, ficando claro desde cedo que Afonso III tudo aceitara para conquistar a coroa, o que não significava necessariamente que cumprisse. Os prelados do reino, e nomeadamente o arcebispo de Braga, exigem ali que o Rei faça observar o Juramento de Paris e consideram que ele o deve mandar publicar por todo o País, para que seja conhecido pelos ricos-homens, oficiais e juízes do reino. Dois escassos anos após a morte de Sancho II, portanto, Joam Viegas de Portocarreiro está já em oposição ao Rei, exigindo-lhe que cumprisse o que diante dele tinha jurado.

$\mathrm{Na}$ resposta a estas exigências, o Rei apoia-se no conselho do primo de Joam Viegas, Fernão Anes de Portocarreiro, deão em Braga. Entre muitos outros aspetos, Afonso III afirmará não ceder ao Arcebispo a apresentação de eclesiásticos para as igrejas de padroado régio, que, naturalmente, conserva para si próprio, de modo a recompensar as suas clientelas (VENTURA 2006: 96-97). Igualmente sintomática da tensão precoce entre a coroa e o arcebispado é a carta que Inocêncio IV envia a Afonso III, em 1251, instando-o a admoestar todos os grandes e poderosos do reino que tentassem impedir o arcebispo de Braga e demais bispos de castigar os monges, a pretexto de serem padroeiros dos mosteiros. Joam Viegas deverá estar em Coimbra com o Rei, quando a carta ali chega (CUNHA 1634: 132).

A intervenção do arcebispo de Braga na tentativa de aceitação pelo Papa da bigamia do Rei é descrita com perplexidade por R. Cunha. Os factos eram natu- 
ralmente indefensáveis junto do Papa, ainda mais por um eclesiástico e por um Arcebispo: «uma aliança que havia sido celebrada com uma consanguínea em quarto grau, ainda sem idade núbil, e, sobretudo, à custa do abandono de sua mulher legítima, a condessa de Boulogne» (CUNHA 1634: 134; VENTURA 2006: 149). Segundo R. Cunha, o Rei insiste que seja o Arcebispo a apresentar a causa junto do Papa e este espanta-se por o Arcebispo ter aceitado fazê-lo: «Estranhou sobre tudo ao Arcebispo aceitar tal embaixada, mandandolhe, q Roma, \& se viesse de Roma, \& se viesse a fazer residencia entre suas ouelhas ${ }^{19}$. $\mathrm{O}$ episódio não deixa de contribuir significativamente para o perfil de Joam Viegas de Portocarreiro, que terá sido colhido pela morte a 16 de novembro de 1255, tendo-lhe sucedido D. Martinho Giraldes.

\section{As cidades}

Independentemente das marcadas diferenças que podiam transmitir a cada espaço urbano uma face singular, a cidade é um espaço de convivência de grupos sociais diversos, incluindo os nobres, os membros do clero e outros homens livres, como os burgueses ou vilões, ou seja, mercadores, artesãos e ministeriales de clérigos e nobres (мATTOSO e SOUSA 1993: 27). Segundo as Inquirições de 1258, as casas na cidade de todos os homens livres estavam isentas de prestação ao Rei, o que estabelecia um certo princípio de igualdade entre todo ${ }^{20}$. Os nobres, porém, nem sempre eram bem-vindos neste espaço. Em Lamego, por exemplo, «o bispo e os cónegos da catedral invocavam o privilégio de couto para recusar aos nobres não apenas o direito de construírem no burgo, mas também o de aí morarem, mesmo em casas alheias» (ibidem, p. 278). Em todo o caso, quando admitidos na cidade, isto é, quando lhes era permitido viverem e edificarem dentro dos muros da cidade verificava-se que os benefícios dos nobres, na cidade, eram iguais aos benefícios das outras classes de homens livres, uma vez que estas também se encontravam, habitualmente livres de impostos, no espaço urbano (ibidem, p. 280).

Os bispos dispõem de uma corte e de uma clientela, disputando com o Rei os benefícios e lugares disponíveis a atribuir (FERNANDES 2010: 205). Ajudará à perceção do estatuto de um bispo medieval, e das pessoas em seu redor, o conhecimento do conteúdo do testamento que o bispo de Lamego, falecido precisamente em 1246, deixou:

$19 \ll$ O clero português justificara todavia a atitude do monarca por «razões de Estado» ou seja, «por causa dos graves e evidentes perigos que o ameaçavam [ao Rei] e ao reino» (VENTURA 2006: 149). 
Fala do seu escravo «mouro negral», que ficaria a pertencer ao deão e a seu sucessor D. Pedro Anes. Possuía duas mulas, uma amarela e outra zamorense; legava a primeira ao tesoureiro Juzam e a sua mulher, e a segunda a Miguel Martins. Do seu guarda-roupa menciona uma capa de «ingrês» e mais seis, uma delas de agasalho chamada «epitognum», duas de saião e uma de burel que legava a um surdo de nome Martim Soeiro; refere mais dois saiões e uma garnacha que destinava a D. Egídio de Almacave juntamente com o seu chapeirão de «ingrês». E continua a longa lista de legados: ao criado Pedro uma «chalamidem de Chardes», ao prior de Cárquere um manto de canulino, uma capa de grizan e um copo de mazar; a cerca de uma dúzia de pessoas vários moios de pão, capa de pele, cobertor e travesseiro; a Maria Pelágio, uma pele de cabrito e quatro moios; a Gonçalo rebelo, quatro moios e um saião de burel; ao cozinheiro Pedro, quatro moios e oito ao criado do mesmo nome, acrescidos de dois maravedis velhos; ao rapaz da cozinha um saião de burel; à mulher do ferreiro Miguel, uma pele de cabrito; à irmã do tesoureiro, de nome Elvira Mendes, cinco moios e uma espécie de tabardo que chama «epitologium»; Afonso Martins receberia o burro negro; o chantre o copo de prata que tinha pertencido ao cónego Pedro Pires; o arcediago João Egas os panos fortes de palha e duas vacas que pertenceram a D. Maria; a João Soeiro o «rousinum quem portabat», mais dez moios e uma vaca em Eirosinho; à criada de Vila Maior e a vários serviçais de Trevões, certas medidas de pão; os três bois desta última localidade eram repartidos por outras tantas pessoas; o escolar Domingos Anes, receberia 20 libras legionenses; Martinho de Parada o vinho da cuba de Valdigem; à «mulieri portae clausae» (emparedada) legava dois moios, ao manco do Castelo três e aos mercenários dois maravedis para as peles. Como era de esperar, D. Paio não esqueceu os mosteiros de religiosos [...] (COSTA 1977: 123-124).

Por outro lado, os nobres afastavam-se, pelo menos tendencialmente, do exercício de cargos municipais (juízes etc.), ainda que os controlassem na sombra: «mesmo quando se submetiam às mesmas exigências que os burgueses e cavaleiros-vilãos, os nobres não gostavam de se misturar com eles e não aceitavam exercer directamente funções próprias de vilãos, por mais vantagens materiais que isso lhes pudesse trazer $\gg$ (MATTOso e SOUSA 1993: 280-281).

Só o desenvolvimento de uma aristocracia de raízes menos antigas, no espaço urbano, e menos resistente a envolver-se em atividades económicas relacionadas com o comércio e os serviços fez multiplicar a presença de uma nobreza cada vez mais próspera na cidade, como foi o caso de Santarém, na segunda metade do século XIII (ibidem, p. 286-288). Mesmo assim, a nobreza mantém-se afastada 
do exercício de cargos municipais, embora tente influenciar as eleições municipais no sentido de colocar funcionários favoráveis aos seus interesses. Como diz J. Mattoso e A. Sousa, «Dir-se-ia que ninguém pensava sequer na eventualidade de confiar cargos concelhios a fidalgos, embora eles participassem, como habitantes das cidades, nas decisões dos concelhos, a título de cidadãos» (ibidem, p. 289). Desta situação resulta que, no século XIII, os nobres viviam nas cidades, «sem aí poderem exercer plenamente os seus privilégios» (ibidem), o que terá ajudado a fomentar o poder das oligarquias urbanas.

As lutas dos cidadãos contra os bispos são frequentes, tanto que os encontramos a aliarem-se muitas vezes ao Rei contra os bispos, como no caso do ataque ao arcebispo de Braga feito por cidadãos a mando de Afonso II e comandado por um cavaleiro de Coimbra e outro do Porto. Mas há também o conflito prolongado entre os cidadãos do Porto e o seu Bispo, a propósito da concessão do burgo ao Bispo, feito por D. Teresa, trisavó de Sancho II (FernANDeS 2010: 200).

A cidade é por outro lado também o espaço da luta entre o Rei e os bispos pela colocação de clientelas nas igrejas. Segundo o uso, deveria ser o Bispo a prover de clérigos as igrejas, o que tinha especial importância pela regra que impunha a eleição do Bispo pelo cabido. Mas o Rei intervinha impondo a colocação dos seus fiéis. Disto mesmo se queixava por exemplo D. Soeiro Viegas, bispo de Lisboa (ibidem, p. 70). Pedro Salvadores, bispo do Porto, repete as acusações feitas anos antes a propósito das igrejas de Lisboa: que o Rei, quando as paróquias vagam por morte do prior, as entregava a lacaios e que apresentava depois pessoas «inúteis, estranhas e desconhecidas» que não queriam receber ordens do presbítero e que, portanto, desrespeitavam as imposições canónicas. A razão: são indivíduos da sua «família», entenda-se, do seu grupo clientelar (ibidem, p. 202).

Como se percebe por estas queixas, o Rei demorou a abdicar do direito de dispor dos benefícios eclesiásticos para os distribuir pelos seus homens, tirando ao Bispo precisamente a mesma faculdade (ibidem). Os dois poderes batem-se pelo controlo dos benefícios associados às igrejas, que, juntamente com os ofícios, significam o domínio de parte importante das redes urbanas que sustentam a oligarquização em curso na época.

Como afirma H. Fernandes, no espaço urbano, onde a nobreza, no início do século XIII, tinha uma presença reduzida, a dependência a que, por conforto, podemos chamar vassalidade não envolve pessoas da nobreza «mas pessoas comuns, eventualmente mesmo não cavaleiros, pertencentes às clientelas de alguns clérigos mais importantes, priores de igrejas paroquiais e de colegiadas. Bem como, claro, do próprio bispo» (ibidem, p. 71).

Move-se no mesmo espaço um conjunto de funcionários nomeados pelo Rei - alcaide, almoxarife, escrivão, alcaide-do-mar, meirinhos, alvazis - que perten- 
cem a uma oligarquia em crescendo de poder neste início do século XIII. De tal forma que, quando colocados diante de um conflito entre o interesse do Rei e o interesse da oligarquia, escolhem o interesse desta. Organizada em rede, esta oligarquia envolve os «familiares», fomenta a interdependência e opõe-se tanto ao Rei quanto ao Bispo, o que complexifica os conflitos entre estes dois poderes, já de si relativamente interdependentes (ibidem, p. 74, 76).

É na cidade que se instalam práticas de extorsão pelo Bispo e pelos prelados das igrejas, os quais se recusavam a ministrar os sacramentos a quem não lhes deixasse em testamento determinados bens. Tais práticas levaram o Papa a recorrer ao clero regular para julgar questões da diocese (ibidem, p. 72), o que faz entrar na cidade mais um elemento e mais um foco de conflito.

A cidade é também o lugar daqueles que, não dispondo de nenhum cargo, estão reduzidos à proteção de um poder exterior à cidade, ou seja, o do Rei. Este é o caso de pescadores, marinheiros, mouros e judeus, que o Rei procura proteger contra os abusos das oligarquias atribuindo-lhes privilégios. São estes grupos que apoirão o Rei e lhe proporcionarão fontes de receita, defendidas pelo foral (ibidem, p. 78-79).

Os interesses dos protagonistas das cidades - rei, bispos, ordens, pauperii, oligarcas - são por natureza conflituosos. A escassez que vem instalar-se, devido possivelmente a uma explosão demográfica a que os recursos disponíveis não podiam dar resposta (MATTOSO e SOUSA 1993: 61, 70), elevaram as tensões ao grau de violência que acabaria por marcar os acontecimentos do meio do século XIII.

\section{A deposição de Sancho II de Portugal}

Os conflitos entre os bispos e o rei de Portugal tiveram diversos episódios e foram-se agravando em violência ao longo dos últimos anos de reinado de Sancho II. Em 1231, Soeiro II, bispo de Lisboa, queixa-se de que o Rei «mandara devassar as casas dos clérigos, a fim de verificar se estavam lá mulheres; que interferira na justiça feita pelo Bispo e o arcediago aos clérigos; que ignorava o foro eclesiástico; que admitia excomungados e judeus nos cargos públicos; que entregava a arrematação de direitos reais a mouros e judeus; finalmente, que dispunha a seu bel-prazer das igrejas vagas» (FERNANDES 2010: 252). O reino é interditado, em consequência (ibidem, p. 251). O braço de ferro entre a coroa e a Igreja começou em Lisboa e estendeu-se ao Porto, em 1233-1234. O clero, seguindo as determinações do Concílio de Latrão, procurava impor a sua independência judicial e económica; na prática, esforçava-se por dispor do seu direito aos benefícios eclesiásticos e usá-lo para controlar as redes de poder das cidades (ibidem, p. 252). 
O bispo de Coimbra, Pedro Soares, manteve-se leal ao Rei, desrespeitando o interdito ordenado pela hierarquia a que pertencia, o que lhe custou o afastamento da cadeira episcopal, onde foi substituído por Tibúrcio (COSTA 1963: 187-195). Em respeito pelo acordo assinado com D. Estêvão, o Rei deixa Braga imperturbada (FERNANDES 2010: 253). Nesta altura, no entanto, apesar da excomunhão do Rei e do interdito do reino em 1234, nem a autoridade do Rei é questionada nem a ordem se considera desequilibrada para além do tolerável. Gregório dirige ainda, nesta data, ao arcebispo de Braga, a pedido do Rei, uma bula em que proíbe a promoção de membros da corte régia a ordens eclesiásticas, sem o consentimento do Rei (ibidem, p. 260).

Em 1235-1236 terá ocorrido em Coimbra uma cúria em que Sancho II ainda se apresenta rodeado dos seus magnates e dos seus bispos, demonstrando capacidade para manter unidos em torno de si os diversos elos do poder. A partir de 1236, por razões pouco claras, começa a perder-se a força concêntrica que mantém o poder político unido em torno do Rei, apesar de todas as lutas dentro dele (ibidem, p. 267).

O chanceler mestre Vicente age pela última vez em janeiro de 1236, depois de, muito singularmente, o seu nome ter surgido a substituir o do Rei no sinal rodado da chancelaria. Em vez de «Sancius secundus dei gratia portugalensium rex», ou já sem evocação divina «Sancius illustris rex Portugalensis», nas doações de 1 de outubro de 1235 a 3 de janeiro de 1236; a legenda do sinal rodado diz «Magister Vicentius episcopus Egitaniensis cancellarius curie», o que nunca tinha acontecido nem voltará a acontecer. Depois deste ímpar acontecimento, mestre Vicente é abruptamente afastado da chancelaria e esta, que permanecerá vaga até 1238 , mostra-se desorganizada ou simplificada. Mesmo quando é assumida por Durão Forjaz, a administração central não deixa de dar sinais diversos de turbulência (ibidem, p. 271-273). «Sem o seu chanceler [mestre Vicente], Sancho começará finalmente a parecer-se com a imagem que os seus contemporâneos fizeram dele» (ibidem, p. 273).

Paralelamente, verifica-se, pela mesma altura, uma substituição dos responsáveis pelas tenências do reino, em percentagem sem precedentes (ibidem, p. 273-275). Embora sinal de viragem acentuada, esta reorganização do poder através das tenências, em 1235-1236, demonstra ainda capacidade de iniciativa estratégica do centro, tanto mais que as escolhas dos tenentes para as regiões dão provas de sensibilidade tática (ibidem, p. 276-277) a favor da coroa. Nesta reorganização, Rodrigo Sanches, tio de Sancho (filho da Ribeirinha e de Sancho I), tal como mestre Vicente, é afastado do governo de qualquer tenência (ibidem, p. 277). Os Sousãos são também, em grande medida, afastados do governo das tenências (ibidem, p. 278), cujo mapa mostra o palco da turbatio et guerra, que tomará o reino, e os fiéis do Rei em que este se apoia: Abril Pires de Lumiares, na Beira, 
ligado aos Riba de Vizela, pelo casamento de Urraca Abril com João Martins; e os Soverosa na terra de Sousa, bem como, através da ligação a Riba-Minho e Baião, na posição preponderante de Alto Minho (ibidem, p. 278-279).

Terá sido por esta altura, isto é, nos meados da década de 30 , que começou a instalar-se no reino a desordem generalizada. Disso dão conta as testemunhas de uma contenda judicial decorrida em 1252, entre as quais estão vários membros do alto clero, incluindo o arcebispo de Braga, Joam Viegas de Portocarreiro. Às testemunhas é perguntado quando tinha começado o que se chamava «tumulto e guerra» no reinado de Sancho II, quais as razões e que formas tinha assumido. As respostas compõem o retrato do contexto social da década que precede imediatamente a deposição de Sancho II e, portanto, também da década que precede a composição das cantigas em que «Don Estevam» foi satirizado. Importa, por isso, ter este retrato especialmente em conta (ibidem, p. 283-284). Duas das referidas testemunhas descrevem a década que precede a deposição do Rei como a seguir se transcreve. Lembremos que os testemunhos datam de 1252, quando o clero tinha já compreendido não dever esperar de Afonso III o cumprimento das promessas feitas para que lhe abrissem o caminho até ao poder.

Há 15 anos - diz João Martins - houve uma grande guerra e tumulto no reino e a guerra e o tumulto eram tão grandes que ninguém ousava andar, com segurança, pelo reino de Portugal. E muitos clérigos, laicos e religiosos eram espoliados e capturados e mortos (ibidem, p. 284-285).

[...] por doze anos no tempo do rei D. Sancho foi tanta guerra e tumulto pelo reino que ninguém ousava sair da cidade de Coimbra. E se saíam capturavam-nos e espoliavam-nos, e ouviu dizer que faziam o mesmo nas outras partes do reino, o que era público e notório (ibidem, p. 285).

Quando as testemunhas são interrogadas sobre as causas de tal estado de coisas, respondem com aparente perplexidade: «Sem causa se fez esta guerra e tumulto»; «não havia justiça no reino e cada qual fazia a guerra e promovia o tumulto no reino à vontade»; «porque não havia quem o proibisse» (ibidem, p. 285).

Deste retrato se depreende, em primeiro lugar, que neste tempo se instalou, não uma guerra polarizada, mas um estado de tumulto tornado comum, «marcado pelas pilhagens, os saques e o rapto ou sequestro instituído como prática generalizada» (ibidem, p. 285). Depreende-se igualmente que a este estado se chegou porque o Rei deixou de exercer a justiça, tendo-se instalado paulatinamente o caos e a violência sem critério. Era assim, porque, não havendo quem o impedisse, assim podia ser. 
Trata-se igualmente de um tempo em que o espaço da cidade se distingue do espaço do campo por um fator novo e essencial: a segurança. $\mathrm{O}$ espaço urbano torna-se o espaço da segurança, embora também aqui esta seja relativa; por oposição ao espaço rural, onde o exercício da violência, do banditismo, praticado por bandos de malfeitores, não encontrava travões (ibidem, p. 286-287). Quando inquirido sobre onde se poderia estar em segurança durante este tempo conturbado, uma das testemunhas responde, precisamente, que nas cidades maiores do reino e nos mosteiros, mas nomeia apenas três cidades: Coimbra, Lisboa e Santarém (ibidem, p. 286). As três cidades referidas na cantiga Don Estevan fez sa partiçon, de Joan Soares Coelho. Note-se que a violência dominante no espaço exterior às cidades era especialmente orientada para os clérigos, alvos fáceis e apetecíveis, sobretudo quando em viagem (ibidem, p. 287). Num tempo em que a justiça se aplicaria com negligência ou não se aplicaria de todo, para qualquer homem armado seria mais aliciante, por fácil e lucrativo, assaltar e raptar clérigos indefesos e abastados, do que servir nas hostes do rei, dos bispos ou das ordens, na expetativa de uma recompensa aquando do saque da terra de mouros (ibidem).

Por entre o banditismo generalizado fora dos muros das cidades, alguns episódios deste período dão conta de que há também violência organizada e orientada por interesses muito precisos. É o caso do rapto e assalto do bispo da Guarda, mestre Vicente, a mando da Ordem dos Templários, próxima do Rei, com a qual o Bispo tinha uma contenda sobre jurisdição territorial. Tal ataque a um Bispo demonstra até que ponto se tinha vulgarizado a violência neste período (ibidem, p. 288). Mestre Vicente queixar-se-á igualmente ao Papa de ser vítima de violência do próprio irmão de Sancho, Fernando de Serpa, entre cujos vassalos se contava o trovador Joam Soares Coelho. As queixas demonstram como o banditismo contagiara a própria família real e os que lhe eram próximos, contribuindo para o clima de desordem geral no reino (ibidem, p. 290).

A constante mobilidade nesta época - dos bispos e cónegos que se deslocam à cúria e entre a corte e as respetivas dioceses, dos nobres entre as cortes régias, dos mercadores no interior das redes comerciais - fazia correr as notícias com a celeridade suficiente para que tal estado de violência e consequente incerteza produzisse um impacte psicológico nos habitantes do reino ${ }^{21}$.

É neste contexto de intimidação facilitada dos clérigos que se inscrevem os ataques protagonizados por Fernando de Serpa em 1237 contra a Igreja e

21 Fernandes (2010: 289). «[...] as populações não tinham escrúpulos em renegar o seu senhor (o próprio Rei) e em pedir protecção a nobres (ricos-homens ou cavaleiros) contra o monarca, tudo porque não havia protecção por parte do poder régio. É o caso concreto de João Anes, bisneto do chanceler Julião Pais, que, em Outubro de 1257, vende uma casa em Coimbra a João Peres de Aboim «em recompensa da grande ajuda que me deste contra o Rei de Portugal”» (ventura 2006: 75). 
eclesiásticos. Mestre Vicente descreve os horrores ao Papa: assalto aos bens do bispo da Guarda e aos seus clientes ou dependentes, tanto no bispado da Guarda / Idanha, como no de Lisboa; assassínio em Santarém, diante do Bispo, de clérigos que eram escrivães do Rei (ibidem, p. 291).

É também Fernando de Serpa que ataca o candidato preferido do Papa à cadeira episcopal de Lisboa (João Rol), em detrimento do favorito real e eleito (Estêvão Gomes), espoliando-lhe os bens, destruindo as casas do deado, queimando utensílios, forçando ao exílio todos os parentes e clientes de João Rol (FERNANDES 2010: 292; COSTA 1963: 258-259). Estes acontecimentos são tão mais graves quanto são perpetrados pelo irmão do Rei, o único membro da família real contemplado no primeiro testamento de Sancho II. Fernando era, por outro lado, nesta época, um jovem, sem casa organizada nem património, e o facto de se ter prestado a servir de braço armado de Sancho II nos violentos atentados e vinganças desta época é muito revelador do espírito do tempo e do ânimo que se espalhava entre a geração mais nova (FERNANDES 2010: 291).

Na sequência destes episódios, a violência vai adquirindo caráter sistemático: «A "rouba" a que se referem as testemunhas das Inquirições era muito mais vasta e global, configurando uma situação de todos contra todos, ao menos no que aos grupos privilegiados diz respeito» (ibidem, p. 293). Vai, por outro lado, ganhando notoriedade fora do reino e, assim, afetando a imagem do Rei. No mundo rural, a violência relaciona-se ainda com os atos de usurpação de propriedade rural que ocorrem no interior mesmo das relações de lealdade próprias da hierarquia política e militar ao mais alto nível. Gil Vasques de Soverosa, um dos homens de Sancho II, por exemplo, usurpa oito casais da sua própria tenência; Vasco Mendes de Sousa protagoniza igualmente extorsões no período em que foi tenente de Bragança. Abril Pires de Lumiares, por seu lado, deixou de fazer justiça sobre quem lhe agrediu o mordomo, a troco de pagamento (ibidem, p. 297).

$\mathrm{Na}$ hierarquia da Igreja, a luta pelo poder económico leva, igualmente, a atos de violência que visam a usurpação de igrejas, reguengos e casais. Há exemplos tanto entre os bispos, quanto nos mosteiros, quanto nas ordens militares. Muitos destes atentados à ordem estabelecida fazem-se com a conivência dos dependentes, que à proteção do longínquo Rei preferem a proteção de um senhor mais próximo (ibidem, p. 297).

No final da década de 30, os conflitos entre o Rei e os bispos agudizam-se, quase sempre em torno da eterna luta pelos benefícios eclesiásticos. Mas nem sempre. Em Lisboa, depois das agressões de Fernando de Serpa a João Rol, candidato apoiado pelo papa, motivadas pelo apoio real a Estêvão Gomes, o Bispo eleito pelo cabido, também este é detido e privado dos bens pelos oficiais do Rei. O apoio da «rainha» Teresa (irmã de Afonso II) a este eleito pelo cabido de Lisboa contra o apoio do Papa a João Rol poderá explicar as oscilações do Rei e 
a impressão de que teria dificuldade em encontrar um Bispo que, em Lisboa, lhe fosse fiel (ibidem, p. 302).

Na contenda entre o Rei e o bispo do Porto, Pedro Salvadores, Sancho contou com o apoio dos cidadãos do Porto, ou seja, as oligarquias urbanas, que se opunham ao Bispo. A descrição que este faz das violentas agressões ocorridas em 1237 é impressionante, mesmo que descontemos algum exagero: «as depredações dos salteadores eram inumeráveis, tendo transformado as igrejas e mosteiros em "espeluncas de ladrões", os claustros em estábulos e prostíbulos, violando crianças, roubando os religiosos e os seus colonos e matando-os sobre os altares $\gg$ (ibidem, p. 303). E enquanto, nas cidades, a luta pelo poder entre o Rei, os bispos e as oligarquias chegava a este ponto de ferocidade, fora das cidades, espaço que os poderes não alcançavam, instalava-se a desordem e a economia de saque (ibidem).

A oposição entre Pedro Salvadores e Sancho II termina com a excomunhão e o interdito, sob cuja pressão o Rei leva oito meses a ceder, abandonando os cidadãos do Porto ao Bispo. Ou seja, para se livrar da excomunhão e do interdito, Sancho II entrega ao bispo do Porto os direitos sobre as atividades comerciais das oligarquias urbanas. Pedro Salvadores resultava assim fortalecido no seu poder económico, e o tesouro do Rei muito depauperado. Em contrapartida, o Bispo compromete-se simplesmente a integrar o exército geral com todos os eclesiásticos da diocese, em caso (improvável) de invasão sarracena do reino (ibidem, p. 305).

Abandonados pelo Rei, os cidadãos do Porto voltam-se para o arcebispo de Braga, Silvestre Godinho, que tenta, em vão, mediar o conflito entre os cidadãos e o seu Bispo. Em resposta, Pedro Salvadores procura trazer a violência dos campos para dentro da cidade «aliciando a atacar e destruir os cidadãos e a sua cidade, enforcando vizinhos e vendendo as mulheres e os filhos de alguns deles "pro denariis", por dinheiro, "como se fossem sarracenos"» (ibidem, p. 308). O concelho, representado por três cidadãos, pede socorro no sínodo realizado pelo Arcebispo em 1239, mas, tratando-se de questão temporal, o Arcebispo e o Bispo remetem-na para o Rei. O concelho, no entanto, já não aceita o reenvio da questão ao Rei, apelando a diversas possíveis autoridades. Podemos por este episódio compreender a que ponto a desautorização em matéria de justiça atinge o Rei (ibidem, p. 309).

Pelos mesmos finais da década de 30, eclode também um conflito com o arcebispado de Braga, com o qual a coroa mantivera longa paz. Trata-se do ataque às liberdades eclesiásticas da diocese de Braga e do incumprimento da doação que Afonso II fizera das dízimas reais. Mestre Silvestre enfrenta o Rei e acaba por ceder, num acordo em 1238, alguns direitos históricos - $<$ o castelo de Penafiel de Bastuço, o direito de cunhar moeda, a capelania e os direitos de 
chancelaria» (ibidem, p. 307) - em troca de igrejas e terras. Deste acordo se deduz que Sancho II se esforça ainda pela centralização e que lhe resta algum poder negocial para tanto, mas não o suficiente para salvaguardar o tesouro, já reduzido, ao enfrentar o poder do Arcebispo, respaldado pelo Papa. O estado caótico do reino e a autonomização crescente das cidades deixavam o Rei menos apoiado nesta negociação (ibidem). Em tal contexto, o Papa adquire cada vez mais poder de pressão, que se manifesta através dos que o representam no terreno, especialmente os bispos (ibidem, p. 308).

Os acordos obtidos com os bispos e os sucessos militares das ordens a sul, no final da década de 30 , provocam uma momentânea união da nobreza em torno de Sancho II, apesar de se notar já a incapacidade do Rei para manter o equilíbrio das principais linhagens no exercício do poder: os Ribas de Vizela e os Soverosa vão ganhando protagonismo. Em 1241, no entanto, a documentação mostra Sancho abandonado dos seus magnates: já só lhe restam os Riba de Vizela, a linhagem dos seus amos, Estêvão e Estevainha Soares (ibidem, p. 310-311). Este facto poderá ter tido que ver com o modo de conquista delegado que Sancho II praticou. Ao contrário do que aconteceu nos reinos vizinhos, o significativo alargamento do território, protagonizado pelas ordens militares, durante o reinado de Sancho II, fez-se quase sempre na ausência do Rei. A distribuição de terras não contribui, portanto, para resolver a crise no reino, nem o isolamento crescente do Rei, que sofre também o afastamento do irmão Fernando de Serpa, com o qual nunca mais terá relações de proximidade, até porque este se torna vassalo da Santa Sé jurando-lhe fidelidade «contra todos os homens», o que inclui o Rei de Portugal (ibidem, p. 321, 324). Quando regressa ao reino, depois de passar por Castela e Leão, Fernando avolumará de resto o grupo apoiante do conde de Bolonha (VENTURA 2006: 63).

O casamento de Sancho com Mecía Lopes de Haro, depois de 1240, é mal recebido e não trouxe ao Rei nenhum dos benefícios que poderia desejar: nem o herdeiro, nem nenhum apoio capaz de travar a derrocada (FERNANDES 2010: 328). Na década de 40, torna-se clara a especial importância de controlar os centros urbanos, já que, fora deles, a turbulência era incontrolável. A acumulação de situações de violência e de tumulto, não apenas na periferia do exercício do poder, mas muito perto dos seus protagonistas, aponta claramente para uma progressiva e cada vez mais grave falta de autoridade central. Entre julho de 1241 e janeiro de 1244, período em que a eleição de um novo Papa se arrasta, quase não restam documentos da chancelaria portuguesa (ibidem, p. 333). O papa Inocêncio IV será eleito em 1243, mas terá de recolher-se a Lyon, em 1244, quando os desentendimentos com o imperador Frederico II se agudizam. Em Lisboa, há um novo bispo, Airas Vasques, «o único que nos anos seguintes erguerá a voz para defender Sancho» (ibidem, p. 334). E em 1244 é eleito o novo 
metropolita de Braga: Joam Viegas de Portocarreiro. No final de 1244 e início de 1245, Sancho II faz doações à Ordem do Templo, cujo mestre era seu colaço, Martim Martins da Maia, num último esforço para rodear-se dos que lhe eram mais próximos.

No início de 1245, a bula Inter alia desiderabilia dá início à execução do plano de afastamento de Sancho II do trono. O Papa recorda os ataques à Igreja e a incapacidade do Rei para os deter anunciando uma solução a divulgar brevemente, em que envolve os bispos do Porto e de Coimbra, além dos dominicanos de Coimbra. É o princípio do fim, e Sancho II devia sabê-lo. O Rei ainda tentou arregimentar o bispo Pedro Salvadores com doações, que foram aceites, mas sem retribuição (ibidem, p. 335).

A guerra civil inaugura-se na lide de Gaia em que se confrontam Abril Pires de Lumiares e Rodrigo Sanches, filho da Ribeirinha, por um lado, e Martim Gil de Soverosa, por outro. Morrem os dois primeiros, opositores do Rei. A 24 de julho de 1245, o Papa emite a bula que priva Sancho II do governo de Portugal embora não da coroa - para o entregar ao irmão Afonso III, que antes jurara, em Paris, tudo o que o Papa lhe tinha exigido que jurasse antes de lhe abrir o caminho para o trono (ibidem, p. 336). O Juramento de Paris é firmado diante de Joam Viegas de Portocarreiro, arcebispo de Braga; de um delegado de Tibúrcio, bispo de Coimbra; e de um conjunto de nobres portugueses.

No final de 1245, Afonso III entra em Lisboa, que o recebe exultante. Os castelos da Estremadura do bispado de Lisboa passam então para o Conde: Santarém, Alenquer, Torres Novas, Leiria, o mosteiro de Alcobaça, a fortificação templária de Tomar. As Ordens abandonam Sancho II por fim, e o Rei recolhe a Coimbra com os seus cavaleiros e os de Martim Gil de Soverosa, onde permanecerá durante 18 meses até se exilar em Toledo. Enquanto permanece em Coimbra, Sancho ataca o cabido, prende-o e fica-lhe com os bens, e com os do Bispo ausente (ibidem, p. 336). Mecía é raptada por Raimundo Viegas de Portocarreiro, irmão do arcebispo de Braga, ato que visava impedir a descendência de Sancho II. O infante castelhano, futuro Alfonso X, ainda vem em sua defesa, em 1246, e a Beira deixa de estar sob o conde de Bolonha; Leiria é devastada. A guerra equilibra-se momentaneamente (ibidem, p. 337), mas a intervenção militar castelhana no conflito, que contraria aliás a vontade de Fernando III de Castela e Leão, leva o bispo de Coimbra e Joam Viegas de Portocarreiro, arcebispo de Braga, a excomungarem o pai de Alfonso. O príncipe castelhano acaba por recolher a Castela, levando Sancho II, e o Papa se encarregará pouco depois de absolver Fernando III (VENTURA 2006: 77). Talvez acreditem numa retirada estratégica e temporária, mas não será assim. 


\section{Os trovadores}

JOAm SOARes COElho, descendente por via bastarda de Egas Moniz, foi vassalo de Fernando de Serpa, o irmão mais novo de Sancho II e Afonso III. Na qualidade de testemunha intervém no documento, datado de 1235, em que o Infante reconhece a autoridade do bispo de Évora em Serpa (мATTOSo e SousA 1993: 434). Depois desta data, supomos que o trovador terá seguido o percurso do Infante, razoavelmente conhecido.

$\mathrm{Na}$ sequência da já mencionada cumplicidade com Sancho nas violências contra o clero, de que há notícia em 1237 e 1238, o Infante dirige-se à cúria papal, onde já se encontra em 1239 e onde recebe, entre várias penitências, a incumbência de se dirigir a Castela Leão, a fim de ali combater os mouros ao lado de Alfonso de Molina, filho de Alfonso IX de Leão e irmão de Fernando III de Castela e Leão. Joam Soares Coelho terá acompanhado Fernando em todo este percurso, já que desencadeia em Castela a discussão em torno da Ama, ou seja, Urraca Guterres Mocha (CORREIA 2017).

A chegada a Castela terá acontecido durante o ano de 1241, o casamento do infante de Serpa com Sancha Fernandes de Lara aconteceu antes de 5 de fevereiro de 1242, data de um documento que já o dá como casado. Mas, em novembro 1243, Fernando de Serpa está de regresso a Portugal e assume a tenência de Tarouca ${ }^{22}$. Entre fevereiro de 1244 e setembro de 1245 , no entanto, a tenência de Tarouca passará de mãos quatro vezes entre o Infante e Abril Pires de Lumiares (FERNANDES 1970: 133-136). Sinal claro dos tempos conturbados que se viviam e da falta de autoridade real.

O martirológio antigo da Sé de Lamego regista a morte do Fernando de Serpa em janeiro de 1246 (VENTURA 1992: 553). A partir desta data, ter-se-á iniciado a trajetória de aproximação de Joam Soares Coelho à corte portuguesa. Em janeiro de 1246, a guerra civil tivera já início: o Papa entregara o governo do reino ao conde Afonso e o rei Sancho II fora afastado do trono. Para Joam Soares Coelho, como para toda a nobreza e clero, era inevitável escolher um partido. E Joam Soares escolheu certamente o partido que já Fernando de Serpa tinha escolhido: (VENTURA 2006: 64) o daquele que viria a ser Afonso III. Em todo o caso, o trovador só volta a ser mencionado na documentação como conselheiro do Rei, a propósito da primeira reunião plenária da cúria, em novembro de 1248, já depois de morte de Sancho II. Para documentar o período de vida de Coelho

22 A. Fernandes (1970: 132) considera a tenência de Lamego e Tarouca: «É tenente de Lamego, Tarouca e vizinhas o infante D. Fernando (de Serpa) ». L. Ventura refere a tenência de Lamego: «Volta de Castela por volta de 1243, assume a tenência de Lamego entre Novembro de 1243 e Setembro de 1245 e participa na guerra civil no partido contrário ao do seu irmão Sancho II (2006: 63). 
entre janeiro de 1246 e novembro de 1248 , restam-nos, pois, as sátiras contra «Don Estevan». São estas que atestam o esforço de serviço em prol dos interesses do novo Rei.

Não será sem importância fazer notar a este respeito que as famílias de Joam Soares Coelho e dos Portocarreiro, pelo ramo respeitado de Joam Henriques de Portocarriro, têm um ponto de interceção. Mor Anes Coelho, filha de Joam Soares, casou com Joam Pires, filho de Pero Anes, tenente de Parada entre 1223 e 1248, e neto de Joam Henriques. Como vimos anteriormente, Pero Anes ter-se-á mantido fiel a Sancho II e tê-lo-á acompanhado mesmo ao exílio, embora depois da morte do Rei, a partir de 1251, ocorra integrado no rol de conselheiro régios de Afonso III. O que não foi caso único e não deve espantar.

Joam Soares Coelho permanecerá próximo da corte portuguesa, onde confirmará diversos documentos como conselheiro de Afonso III, até 1279.

Dada a fidelidade que uniu provavelmente Joam Soares Coelho a Fernando de Serpa até à morte deste, convirá recordar brevemente o relacionamento deste infante com Sancho II. No primeiro testamento do Rei, feito em 1231, o infante D. Fernando é o único legatário laico (FERNANDES 2010: 87). Em 1229, quando Sancho II recebe o legado papal João de Abeville, toda a família real se encontra afastada da corte, exceto Fernando e o tio bastardo de Sancho II (Rodrigo Sanches, filho da Ribeirinha) (ibidem, p. 215). Em 1237 e 1238, o infante torna-se no braço armado de Sancho, atacando por diversas vezes os bens e as pessoas da Igreja. Era por esta altura muito próximo de Sancho II e a única família que lhe restava na corte, dado que Rodrigo Sanches se tinha afastado já (ibidem, p. 290-291). Quando, em 1239, Fernando de Serpa se desloca a Roma para pedir perdão pelos pecados cometidos, o papa Gregório IX atribui-lhe tantos benefícios que parece deixar claro ver nele uma primeira solução para a sucessão de Sancho II. Mais contribui para esta suspeita ter o Papa anulado um acordo entre Fernando e Sancho II que beneficiava o Rei, além de o Infante se tornar ali vassalo da Santa Sé, jurando-lhe fidelidade. Sancho II perde um aliado (ibidem, p. 323-324; VENTURA 2006: 62). Fernando apoiará depois o irmão Afonso III contra o irmão Sancho na guerra civil (FERNANDES 2010: 63). Em documentos de 1247 e 1248 confirma-se que o Conde é acolhido e protegido pela tia D. Teresa e o tio Pedro Sanches, aos quais se junta Fernando de Serpa e outros, grupo em que se reconhece o partido senhorial apoiante das irmãs de Afonso II na contenda empreendida por este contra elas. Entre os vassalos de Fernando de Serpa, nesta documentação, está Joam Soares Coelho (ibidem, p. 81-82).

MEM RODRIGUeS TENOIRo, de acordo com C. Michaëlis Vasconcelos (1990a, vol. 2, p. 406), seria descendente, igualmente por via bastarda, de Afonso IX de Leão, sendo a origem da linhagem galega, com centro senhorial junto a Pontevedra. 
Os Livros de Linhagens apenas referem Pedro Rodrigues Tenoiro: «adulto em 1248», como indica C. Michaëlis Vasconcelos (1990a, vol. 2, p. 405) e respetiva descendência. Mem Rodrigues terá sido irmão deste nobre ${ }^{23} \mathrm{e}$, portanto, jovem adulto também, nos anos em que o reino de Portugal se divide em dois partidos.

Pela atividade militar que desenvolve em Castela, é recompensado no Repartimento de Jerez de La Frontera, entre 1264 e 1269. Em 1277, assume o cargo de almoxarife em Sevilha, mas R. Oliveira tem já dúvidas de que o Mem Rodrigues Tenoiro mencionado como vassalo de Sancho IV de Castela, em 1290, seja ainda o trovador. Já o vassalo de Sancho IV, documentado em 1309, e o Adiantado da Fronteira de Alfonso XI, documentado em 1315, em ambos os casos com o mesmo nome, não o serão certamente (OLIVEIRA 1994: 390). Este percurso orientado para Castela, a partir de meados do século, depois da intervenção na discussão de que nos ocupamos, poderá ter-se devido aos ascendentes familiares.

Importará lembrar que Mem Rodrigues Tenoiro participa numa curiosa tenção com Juião Bolseiro, em que, segundo defendi, satirizam Rodrigu'Eanes de Vasconcelos, apontando-lhe a substituição de argumentos pela violência física, por um lado, e a cobardia herdada do pai, por outro (CORREIA 2011: 26-27). No estudo que fiz, não encontrei nenhum elemento que me possibilitasse a datação ou mesmo a localização desta tenção. Exceto o facto de tanto Rodrig'Eanes de Vasconcelos como Juião Bolseiro estarem relacionados com Joam Soares Coelho. No primeiro caso por via familiar, uma vez que Rodrigu'Eanes era filho de uma irmã de Coelho, casada precisamente com o Tenreiro. No segundo caso, porque também Coelho construíra uma tenção com Juião Bolseiro a propósito do debate em torno da Ama.

Mas as ligações aumentam, se considerarmos a discussão em torno de «Don Estevan». Porque Joam Pires de Vasconcelos, o Tenreiro, satirizado por Tenoiro com Juião Bolseiro, pela cobardia, era sobrinho de Estêvão e Estevainha Soares (мAтTOSo 1980, vol. I, 43), filho de Teresa Soares, a terceira irmã. Todos terão herdado a alcunha Torto do pai. Recordo que é precisamente Tenoiro que usa o adjetivo alusivo na cantiga Don Estevan achei noutro dia.

As referências à violência na tenção entre Tenoiro e Juião Bolseiro, que terão sido uma sátira por mimetização da situação observada por ambos, poderão, igualmente, refletir o clima de descontrolada violência que se vivia no reino. É possível, portanto, que a tenção entre Bolseiro e Tenoiro esteja também ligada a

23 O Livro do Deão (mattoso 1980, vol. I, p. 158) inclui nas listas dos filhos de Pero Rodrigues o nome de Mem Rodrigues ( «Gonçalo Pires e Rui Pires e Mem Rodrigues e Inez Pires»), o que não faz sentido, dado que o patronímico dos filhos de Pero Rodrigues é Pires. No Livro do Conde, a lista indica dois filhos de nome «Mem»: «Meem Pirez e Meem Rodrigues» (MATtoso 1980, vol. 2, p. 188). R. Oliveira (1994: 390) põe a hipótese de que, durante a transmissão deste livro de linhagens, se tenha procedido à correção desta lista de nomes, sem a necessária eliminação do erro. Creio ser uma conjetura acertada. 
este período e que tenha sido composta em Portugal. Não devemos esquecer que o caso do Tenreiro, além de sublinhar a cobardia de Joam Pires, põe igualmente em destaque o exercício da justiça pelo rei Sancho II, cuja negligência é precisamente invocada para o depor. Note-se como a narrativa do episódio é concluída no Livro do Conde: «E entom veo a beijar a mão a el rei Pedr'Eanes e os outros cavaleiros que o acusavam, e disserom que o mantevesse Deus, e que julgara come mui boo rei e dereito» (MATTOSO 1980, vol. 2, p. 408).

As origens de AIRAS PERES VUitorom são incertas. Carolina Michëlis Vasconcelos refere um «Archidiaconus Magister Petrus Arie Vuy ${ }^{\text {to }} \gg$, associado à igreja de Lugo, que poderia ser pai de Airas Peres Vuitorom. Mas a própria filóloga admite: «Faltam porém os meios de provar que Ayras Peres era filho de Pedro Ayres. Nem mesmo é certo Vuy to ser deturpação de Vuytre, Vuyturon ou Vuyturinho» (vASCONCELOS 1990a, vol. 2, p. 623-624). Com menos fundamento documental, outros autores conjeturaram uma origem portuguesa, considerando o conhecimento da realidade portuguesa e os contactos com trovadores portugueses. Almeida Fernandes identificou-o com Airas Peres, natural de Vitorino dos Piães, mencionado nas Inquirições de 1258. Tavani considerou-o também um cavaleiro português exilado em Castela após a guerra civil de 1245-1247.

Resende de Oliveira sublinha, no entanto, não haver vestígios na documentação do apelido do trovador em Portugal, por oposição à Galiza, onde o historiador pôde documentar um «Pero Pais, cavaleiro, dito "Vultoran"», em 1255, e um João Peres «Voytorum», em 1262, que R. Oliveira considera, «sem dúvida», tratar-se de um irmão do trovador. Esta identificação leva-o a estabelecer a origem do trovador na região entre Orense e Santiago de Compostela (oliveIRA 1994: 320), opinião questionada recentemente por Ron Fernández ao chamar a atenção para a existência do topónimo Buitorón, no atual concelho de Muxía ${ }^{24}$. Em resumo, as opiniões divergem quanto à origem portuguesa ou galega de Airas Peres Vuitorom; a documentação, não sendo irrefutável, aponta para a Galiza.

Devo acrescentar ao raciocínio apresentado que todas as cantigas de Airas Peres Vuitorom chegadas a nós são cantigas de escárnio, entre as quais está a famosa cantiga A lealdade da Bezerra pela Beira muito anda, onde, em cada estrofe, ocorrem versos latinos. Está também a cantiga Joam Soares, pero vós teedes, relacionada com o ciclo da Ama, onde o trovador se arroga o estatuto de juiz de trovadores. E está ainda a cantiga Joam Nicolás soube guarecer, sobre temática jurídica. O perfil desenhado por estas cantigas aponta para uma cria-

Ron Fernández (2018: 226-227). Será talvez conveniente considerar também, nesta discussão, as notas de Carolina Michëlis sobre o assunto (VASCONCELOS 2004: 84-85). 
ção próxima do meio clerical, o que faz lembrar o documento invocado por Carolina Michaëlis de Vasconcelos.

Em todo o caso, tanto na cantiga A lealdade da Bezerra pela Beira muito anda, quanto nas cantigas em que participa na discussão em torno de «Don Estevan», ou seja, durante os anos da guerra civil, tudo indica que estivessem em Portugal. Além do mais, é claro ter tomado o partido de Sancho II, enquanto este foi vivo, que era também o partido de Castela, para onde Airas Peres Vuitorom se encaminhou depois. R. Oliveira considera que o trovador chegou a Portugal integrado no exército do príncipe Alfonso que veio socorrer Sancho II, possivelmente ao serviço de Rodrigo Gomes de Trastâmara (oliveIRA 2006: 234).

De regresso a Castela, começou por participar na conquista de Sevilha. Mas, depois, só as cantigas de escárnio testemunham do envolvimento do trovador com a corte castelhana e as suas personagens, porque se desconhecem documentos em que figure como titular de quaisquer cargos ou bens.

ROI QUEIMADO é igualmente um autor pouco documentado, mas os estudos de $\mathrm{R}$. Oliveira sobre a constituição dos cancioneiros galego-portugueses apontaram para que tivesse nascimento nobre, apesar da ausência do patronímico no nome. $\mathrm{O}$ facto de não haver vestígio de Queimados nem nos Livros de Linhagens nem na documentação que possa relacionar a família com cargos ou bens deixa claro tratar-se originalmente de baixa nobreza rural.

As Inquirições de 1258 mencionam a criação de Roi Queimado no julgado de Valdevez, além de um Pero Martins Queimado, cuja relação com o trovador se desconhece. Há também notícia de um clérigo de nome Estêvão Pais Queimado, cujo filho é legitimado em 1289 (OLIVEIRA 1994: 435).

Diéguez González, referido por Ron Fernández, detetou, na documentação do mosteiro de Meira, referência a um «Roi Perez dito Queimado» já falecido em 1297, levantando a hipótese de que se tratasse do trovador. Também Ron Fernández encontrou na documentação da catedral de Lugo, vizinha de Meira, referência, em 1225, a um «Ruderico Martini Queimado». Identifica igualmente um «Vasco Rodriguez dito Queimado», cavaleiro, na documentação do mosteiro de Santa María de Melón, em 1300, e um «Garcia Rodrigues dito Queimado», na documentação de Oseira, em 1348. A julgar pelo patronímico, ambos terão sido filhos de um «Roi dito Queimado», que poderá ter sido o trovador (RON FERNÁNDEZ 2018: 230-231). Neste caso, teria tido origem não em Portugal, mas na Galiza.

A referência a um João Garcia, na cantiga Preguntou Joam Garcia, tem levado a relacionar Roi Queimado com os Sousa, quer se veja na personagem referida João Garcia de Sousa, quer se veja nela Joam Garcia de Guilhade, trovador igualmente ligado aos Sousa (OLIVEIRA 1994: 435). Também a referência a Guiomar 
Afonso Gata em duas das cantigas do autor apontaram no sentido de uma relação do trovador com a mesma família dos Sousa, uma vez que o pai de Guiomar era cunhado de Joam Garcia de Sousa (LORENZO GRADín e MARCENARO 2010: 17-18).

Roi Queimado e Joam Soares Coelho, dois dos trovadores envolvidos na crítica a «Don Estevan», têm em comum as críticas de Pero Garcia Burgalês. Ou, dito de forma talvez mais exata, a natureza das críticas deste trovador. Na verdade, como defendi em estudos anteriores ${ }^{25}$, Pero Garcia Burgalês critica Joam Soares Coelho por, no caso da Ama, não ter usado a justificação que a tradição lhe oferecia para o desvio operado nas cantigas em louvor à Ama, ou seja, a loucura provocada pelo sofrimento amoroso. Quanto a Roi Queimado, a crítica desenvolve-se na cantiga Roi Queimado morreu con amor, onde o Burgalês ataca uma falha gramatical do trovador para sublinhar que a vulgarização do tradicional tópico da morte por amor lhe retiraria força retórica (CORREIA 2016: 213-215). Tanto no caso da crítica a Coelho quanto no caso da crítica a Queimado, além do tom pedagógico assumido pelo Burgalês, há em comum a crítica literária em defesa da tradição. Como se o Burgalês procurasse moderar os excessos de trovadores ansiosos por mostrar um domínio da arte, que talvez não fosse (ainda) tão grande quanto julgariam ou desejariam.

Em todo o caso, parece comum a todos os trovadores que participaram nos ataques a «Don Estevan» a origem na pequena nobreza, e que todos estiveram, nos meados do século XIII, em percurso de aproximação às cortes régias. Em plena crise de sucessão no reino de Portugal, terão procurado servir aqui com um instrumento que lhes poderia ser politicamente tão ou mais útil quanto a espada e o cavalo: a arte da sátira.

No caso de «Don Estevan», só Coelho atira contra o Rei; todos os outros atiram em defesa do Rei. Mas, após a morte de Sancho II, embora a crítica a «Don Estevan» pareça permanecer inalterada, passa na verdade a servir os interesses do novo Rei. Ainda assim, só Coelho será acolhido no círculo próximo de Afonso III. Tenoiro e Vuitorom regressarão a Castela, e, sobre o percurso posterior de Queimado, nada se sabe.

A julgar pelo que conhecemos do futuro de todos os trovadores que atacam «Don Estevan», a opção de Coelho terá sido a mais proveitosa ou a mais duradouramente proveitosa. Mas, como sabemos, Afonso III distinguiu-se precisamente pela valorização de uma nobreza que evidenciasse conhecimento, mesmo que fosse de nascimento menos elevado.

25 Em último lugar, Correia (2017: 96-98). 


\section{Interpretações recentes}

\section{A identificação}

Em 1904, Carolina Michaëlis, vendo em «Don Estevan» «o cego que odiava um Rei e era partidário dum conde», faz a primeira proposta de identificação da personagem satirizada por Vuitorom, Coelho, Tenoiro e Queimado. Apesar da incerteza manifestada pela filóloga, a proposta de identificação feita será aceite e repetida por todos os estudiosos até mais de 100 anos depois, quando, em 2006, R. Oliveira a questiona. Suspeita Carolina Michaëlis ( «a minha opinião não passa de mera suspeita ${ }^{1}$ ) de que «Don Estevan» fosse Estêvão Anes, o colaço e chanceler de Afonso III, tão poderoso e favorecido na corte do novo Rei, apesar da modesta origem, quanto provavelmente detestado por isso mesmo.

A contestação desta proposta, por R. Oliveira, assenta na interpretação das cantigas do conjunto. Mais exatamente em algumas referências que ajudam o historiador a desenhar um perfil de «Don Estevan». Concretamente, 1 ) as referências à proximidade entre «Don Estevan» e Sancho $\mathrm{II}^{2}$, manifestada nos benefícios recebidos de Sancho II por «Don Estevan» (OLIVEIRA 2006: 238); 2) a referência à partilha de bens em Lisboa, Santarém e Coimbra, o que apontaria para uma idade entre os 40 e 50 anos; 3 ) a ausência de patronímico, apesar do título (Dom), que inviabilizaria a identificação como cavaleiro ou magnate da corte (ibidem, p. 239).

Considerando este perfil, R. Oliveira questiona a identificação com o chanceler Estêvão Anes, que, à data da composição das cantigas, nenhuma proximidade teria de Sancho II capaz de justificar a atribuição de quaisquer benefícios pelo Rei, e seria um homem mais jovem do que os 40 a 50 anos deduzidos. Embora o historiador não proponha nenhuma identificação alternativa, a con-

1 Vasconcelos (1990a, vol. 2, p. 379).

2 Carolina Michaëlis também considera uma grande proximidade do Rei, mas, quando o faz, está ainda a pensar na hipótese ponderada pela bibliografia anterior de se tratar de referências a Estêvão da Guarda e ao rei D. Dinis: «A favor da hipótese de que seja ele o referido, fala o facto de que a pessoa alvo da cantiga aparentemente tinha grande favor junto ao Rei e comia à sua mesa (CV1015). Contra ela, que o nome completo, Estêvão da Guarda, não se cita nem uma só vez.» (vasconcelos 2004: 79). A hipótese de se tratar de referência a Estêvão da Guarda descarta-se por motivos cronológicos, dado que este trovador terá nascido no início da década de 80 do século XIII (OLIVEIRA 1994: 330). 
testação da identificação feita por Carolina Michaëlis não é questionável e não foi questionada desde então. Apenas com base no nome, outros estudiosos levantaram algumas hipóteses de identificação.

Pilar Lorenzo Gradín e Simone Marcenaro ${ }^{3}$ chamam a atenção para três indivíduos referidos nas chancelarias de Sancho II e Afonso III que poderiam ter sido o alvo dos escárnios. A saber: Estêvão Martins, escrivão de uma carta de Afonso III, em 1250, em Évora; Estêvão Anes, cónego de Braga, testemunha de uma carta do mesmo Rei em 1251, em Santarém; e Estevan Perez Espiñel, testemunha do testamento de Sancho II, feito em Toledo, em 1248, que, depois da morte de Sancho II, é mencionado, como muitos outros, em documentos de Afonso III.

Em CMGP faz-se o exercício de busca na documentação da época de indivíduos de nome Estêvão que tenham algum ponto em comum com as referências recolhidas nas cantigas. A primeira hipótese avançada, neste caso, é Estêvão Martins de Briteiros, primo direito do trovador Rui Gomes de Briteiros. Em defesa desta hipótese é indicado o apoio do trovador a Afonso III, que virá a nomeá-lo chanceler; além de os Briteiros disporem de terras em Amarante, localidade mencionada numa das cantigas. A segunda hipótese é Estêvão Peres de Aboim, irmão de Joam de Aboim. São argumentos de defesa desta hipótese: a importância de Joam de Aboim na corte do bolonhês e o casamento de Estêvam Peres com uma dama de Santarém, outra localidade nomeada nas cantigas.

Quanto à terceira hipótese, que, segundo se admite, é invalidada pela cronologia, trata-se do trovador Estêvão Raimundo de Portocarreiro. Também, neste caso, a base para a proposta são o casamento com uma dona de Santarém, terras familiares junto a Coimbra e a proximidade do pai a Afonso III.

Poderíamos, na verdade, juntar a esta lista mais alguns indivíduos de nome Estêvão, como Estêvão Belmir, por exemplo ${ }^{4}$. Mas o problema desta hipótese seria o mesmo de todas as avançadas com dúvida, tanto pelos editores de Roi Queimado, quanto em CMGP. Além dos argumentos de defesa estarem isolados numa ou outra cantiga, estas personagens são secundárias; algumas, como o escrivão e o cónego de Braga, são mesmo provavelmente desconhecidas do centro ou centros onde se move a corte, a nobreza, os agentes com importância num contexto altamente conflituoso. Pela data em que foram compostas, pelas referências ao Rei e ao Conde, ao governo de Portugal, pelo contexto da inaudita

3 Lorenzo Gradín e Marcenaro (2010: 12), onde se remete para trabalho de N. J. Pizarro Pinto Dias.

4 Na verdade, já Carolina Michäelis tinha referido outras possibilidades de nome Estêvão: «Eu comento pela minha parte, primeiramente tendo em conta apenas os que foram cantados, pois não faltam outros favoritos do Rei de nome Estêvão, e cito entre os confidentes de Afonso III: Estêvão Anes de Valadares, Estêvão Anes de Sousa e o seu chanceler e irmão de leite Estêvão Anes de Fermoselhe, de quem já se falou a propósito das amas reais.» (VASCONCELOS 2004: 80). 
deposição por intromissão papal, da guerra civil que culminava pelo menos uma década de caos, violência, insegurança, pela intervenção do príncipe castelhano, que decorria ou se preparava ou tinha acabado de decorrer, estas cantigas não podem deixar de estar altamente politizadas e, portanto, de envolver, mesmo que com os eventuais cuidados, personagem proeminente do contexto político e social que então se vivia. Alguém que se reconheceria mesmo se referido de viés.

Nenhuma das figuras de nome Estêvão indicadas teve especial relevo até à data em que as cantigas foram compostas, nem mesmo Estêvão Peres Espinhel, o mais próximo de Sancho II. Na verdade, não podemos dizer que nenhuma figura de nome Estêvão tenha tido protagonismo de maior, naqueles meses em que o país teve duas cortes, dois centros, dois governantes, um em Leiria outro em Coimbra; nem nos meses que imediatamente os precederam e seguiram. O tipo de protagonismo que torna uma figura tão conhecida de todos, que é evocável só pelo primeiro nome, ou um nome que o substitua, também facilmente reconhecido por todos. Estêvão Anes, o chanceler de Afonso III, virá a ter este tipo de protagonismo, provável razão para $\mathrm{D}$. Carolina ter pensado nele. Mas não ainda naqueles anos em que tinha acabado de regressar ao reino e não tivera tempo de agarrar nas rédeas do poder.

\section{A razão da sátira}

A interpretação das cantigas que Carolina Michaëlis faz leva-a a ver em «Estêvam, o Cégo», uma figura apontada pela «curteza de vista, egoismo ladino, e genio impetuoso, que o levava a dar pancada de cego» (VASCONCELOS 1990a, vol. 2, p. 378) ou «míope, quase cego e também de temperamento violento». Para a filóloga alemã cinco cantigas ${ }^{5}$ estão centradas no ataque à miopia de «Don Estêvão» «e contam ao "sem olhos" tudo o que jamais viu nem verá» - Roi Queimado, Don Estevan, en grand'entençon (B1386/V995); Roi Queimado, Don Marco, vej'eu muito queixar (B1388/v997); Joam Soares Coelho, Don Estevan fez sa partiçon (v1014); Joam Soares Coelho, Dom Estevam que thi nom gradecedes (v1015); Mem Rodrigues Tenoiro, Don Estevan, eu eiri comi (B1473/V1084); - e três centram-se no ataque ao «alto grau de cólera dum Dom Estêvão»- Mem Rodrigues Tenoiro, Don Estevan achei noutro dia (B1472/V1083); Airas Peres Vuitorom, Don Estevan, tan de mal talan (B1474/V1085); e, do mesmo autor, Don Estevan diz que desamor (B1478/v1089) (VASCONCELOS 2004: 79).

5 C. Vasconcelos (2004: 79) acrescenta a este grupo a cantiga Don Estêvan, oí por vós dizer (LAPA 1970a: 465) de Pedr'Amigo de Sevilha, que tem sido afastada deste conjunto satírico por razões cronológicas. 
R. Lapa, quando edita as cantigas de escárnio, oferece, nas breves notas aos textos, o seu entendimento sobre o que, em cada uma, estaria a ser satirizado. Relativamente às cantigas Don Estevan, eu eiri comi e Don Estevan, en grand'entençon considera haver uma sátira pessoal, concentrada num defeito físico de $\ll$ Don Estevan»: a miopia. Igual sátira vê em Don Estevan diz que desamor, onde encontra também crítica à ambiguidade política de «Don Estevan», no que respeita à opção por um dos partidos em conflito. É ainda uma sátira à miopia que R. Lapa encontra em Don Estevan, que lhi non gradecedes, embora aqui veja igualmente alusão a quedas morais, no sentido de não ser apreciado pelos outros. Quanto à cantiga Don Estevan fez sa partiçon, é entendimento de R. Lapa haver um aproveitamento da miopia de «Don Estevan» para satirizar a ambição da personagem, que embora sofresse de défice de visão física, «via perfeitamente os seus interesses» (LAPA 1970a: 353).

Na cantiga Don Estevan, tan de mal talan, o editor das cantigas de escárnio considera haver uma sátira ao facto de «Don Estevan» ser um «homem ingrato e desumano» (ibidem, p. 126), motivada pela vontade de Vuitorom, «acérrimo partidário do Rei deposto D. Sancho II [...] escarnecer dos adeptos do Rei intruso, o ex-conde de Bolonha» (ibidem).

É no comentário à cantiga Don Estevan achei noutro dia que R. Lapa explora uma nova linha interpretativa, posteriormente acolhida com mais ou menos entusiasmo, mas nunca totalmente afastada. Diz o filólogo que, nesta cantiga, $\ll$ o autor insinua vícios homossexuais por parte de D. Estêvão, de mistura com um seu vilão». A razão da sátira seria portanto, nesta cantiga, a homossexualidade de «Don Estevan». R. Lapa não dá mais explicações no breve comentário da cantiga.

Mas, nas notas que entremeia no aparato crítico, identifica os lugares que considera denunciarem o alvo da sátira. Seriam eles o verso 14 e o verso 19. Sobre o primeiro diz o filólogo: «pero xi m’el queria = ainda que ele também quisesse andar atrás de mim. Alusão maliciosa e pornográfica» (ibidem, p. 123). Quanto ao verso 19 , R. Lapa faz uma emenda transformando a forma verbal «sei», que se encontra em ambos os testemunhos, no forma verbal «usei». Desta emenda, resulta o verso: «ca, dê-lo dia en que o eu $[\mathrm{u}] \mathrm{sei}$,», sobre o qual R. Lapa diz em nota: «Outra alusão obscena».

Também sobre a última estrofe da cantiga Don Estêvan, que lhi non gradecedes, comenta o filólogo: «A última estrofe é um pouco duvidosa e contém porventura uma alusão velada aos costumes sexuais do visado» (ibidem, p. 354). Deduzo que o comentário decorra dos últimos versos da cantiga, onde se lê: «ca pois per cort'avedes a guarir, / nunca de vós devedes a partir / un ome que vos trag'acompanhado.» E são estes os argumentos de R. Lapa para supor uma sátira a uma também suposta homossexualidade de «Don Estevan». 
Aceso o rastilho interpretativo por R. Lapa, ele não deixou de fazer caminho junto de quem se seguiu na edição e interpretação destes textos. G. Videira Lopes ${ }^{6}$ generaliza no comentário à cantiga Don Estevan, en grand'entençon, quando afirma: «Rui Queimado alude, como todos os outros trovadores, à sua [de «Don Estevan»] homossexualidade» (2002: 448). E, na cantiga em apreço, encontra alusões em vocabulário mal explicado ou decorrente de emendas injustificadas. É o caso da locução «a feito», onde a autora lê um segundo sentido: «o dobre parece indicar que haverá um equívoco com afeito (o que se enfeita de "afeitar", forma galega de "enfeitar"), termo muito usado pelos trovadores para designarem os homossexuais (pode ler-se, pois: que afeito sodes, cego)» (ibidem). Falta fundamentação para as afirmações sobre o vocabulário.

É também o caso da palavra «artom», reconstruída pela autora a partir da lição dos manuscritos «a son», sobre a qual emenda diz: «artom - arteiro, ou seja, astuto, manhoso, aqui no duplo sentido de malfeitor (D. Estêvão faz a ronda noturna na caça aos malfeitores) e de homossexual» (ibidem).

Tal como R. Lapa, também em CMGP se encontram alusões à homossexualidade de «Don Estevan» na cantiga Don Estevan achei noutro dia, detetando «equívoco erótico» nos versos onde o sujeito diz que «Don Estevan» não vê onde bate com o pau que achou algures.

Igualmente se considera, em CMGP, haver alusões à homossexualidade de «Don Estêvão» na cantiga Don Estevan, tan de mal talan («Nova cantiga contra D. Estêvão $[\ldots]$ agora num traço que reaparece em várias outras composições deste ciclo, o da sua alegada homossexualidade»), embora as explicações desta conclusão sejam bastante sibilinas. Sobre o refrão ( «ides logo trazer come can»), diz-se: «tratar como cão (mas é no sentido físico que reside o equívoco)». Na nota ao verso «mal serviço faz om'en vós de pran» acrescenta-se: «Continua o equívoco, agora com o mau serviço: serve-vos mal / faz em vós um mau serviço». Finalmente, na explicação do termo «besta» encontramos: «o cavalo, numa primeira leitura». Em CMGP não são adiantadas mais explicações sobre as referidas alusões à homossexualidade que estes passos, onde se alude ao serviço feudo-vassálico, conteriam.

Lorenzo Gradín e Marcenaro, os editores de Roi Queimado, são muito cautelosos na indicação das razões da sátira a «Don Estevan», apontando apenas o «cattivo carattere del personaggio schernito» e os «problemi di vista che lo caratterizzano». Quanto ao resto, admitem apenas «alcune espressioni che potrebbero essere non del tutto "innocenti", ma per le quali non è possibile una chiave di lettura sicura». Apenas para os textos de Vuitorom

6 O essencial das interpretações desta autora está já em Lopes (2002), embora, em CMGP se verifiquem algumas alterações. 
admitem também «una piú decisa critica politica», que enquadram na tomada de posição assumida por este autor noutras cantigas a favor de Sancho II (LORENZO GRADIN E MARCENARO 2010: 10).

Marcenaro tem, no entanto, uma opinião mais firme em trabalho posterior, em que defende haver alusões à homossexualidade de «Don Estevan» em todo o conjunto. Encontra-as na oposição «deante / derredo» (Don Estevan, que thi non gradecedes, de Coelho) e «deante / depos, enpos» (Don Estevan achei noutro dia, de Tenoiro); encontra-as nas acusações de défice de visão e de cegueira (em ambas as cantigas de Airas Peres Vuitorom e em ambas as de Roi Queimado); assim como no recurso ao verbo «caer», por Joam Soares Coelho, em ambas as cantigas. Também os passos «trager um ome acompanhado» (Joam Soares Coelho) e «trager come can» lhe parecem alusões à homossexualidade de «Don Estevan», assim como o termo «ome» e o verbo «servir» (MARCENARO 2014: 151-156, 69, 114, 116). O autor não fundamenta nenhuma destas convicções, no entanto.

R. Oliveira é cauteloso ao admitir as alusões à homossexualidade do visado nas sátiras, considerando concentrar-se a sátira em traços de personalidade: «a impiedade para com os seus servidores, tema abordado por Vuitorom e Tenoiro, e onde os investigadores têm detetado também sinais da homossexualidade da personagem, e, por outro lado, os problemas de visão que o afetavam» (OLIVEIRA 2006: 237).

Os fundamentos para admitir uma sátira a uma suposta homossexualidade de «Don Estevan» são, como admitem R. Oliveira e Lorenzo Gradín e Marcenaro, na edição de Roi Queimado, muito frágeis. Eu diria mesmo demasiado frágeis. $\mathrm{Ou}$ assentam em vocabulário conjeturado pelos editores que exploram tal possibilidade, ou assentam na referência a agressões com um pau, muito comuns na época, como vimos; ou assentam, ainda, nas manifestações de amor e dependência, próprias do discurso feudo-vassálico. Ou são forçadas e carecem de fundamento.

Afastada esta razão de sátira, restam, na opinião de todos os estudiosos, as que já Carolina Michaëlis tinha detetado: defeito físico da visão e diversos defeitos de caráter, a saber egoísmo, agressividade e ambição. A crítica política é apenas pontualmente admitida. No caso de uma cantiga (Don Estevan diz que desamor), R. Lapa considera crítica à ambiguidade política da personagem e os editores de Queimado admitem também crítica política no caso das cantigas de Vuitorom, embora não a expliquem. Em CMGP, em nota à cantiga Don Estevan fez sa partiçon, admite-se igualmente uma inexplicada «dimensão política mais lata» para lá das «questões privadas» que dominam o conjunto satírico e, em nota à cantiga Don Estevan diz que desamor, admite-se o «cariz nitidamente político», mas logo também um infundado «caso amoroso, envolvendo eventual- 
mente alguma dama requestada também pelo Conde, muito dado a situações deste tipo».

Excetuando, pois, breves referências a questões políticas, a interpretação que se fez nos séculos XX e XXI, partindo de uma leitura literal da incapacidade para ver, encontrou nestas cantigas sobretudo sátira pessoal: quatro autores, todos da pequena nobreza, portanto bastante dependente, entretidos a vitimizar pelo escárnio uma dada figura histórica fazendo pouco do mal de visão que o acometeria e do mau caráter que lhe achavam.

Se considerarmos o contexto de composição destas cantigas, no entanto, encontram-se razões para duvidar de que a motivação da sátira fosse principalmente pessoal. Afinal, a guerra civil era o culminar de pelo menos uma década de insegurança no reino, onde a justiça não se aplicava e a violência se tinha tornado prática comum, cada vez mais feroz. Em dado momento, o reino teve mesmo dois centros em conflito, duas cortes, a nobreza separada em dois partidos. O clero ameaçava e praticava com agilidade a excomunhão. Sobre as lutas pelo poder entre o clero, a coroa e as oligarquias nas cidades deveria cavalgar então o sentimento de incerteza quanto ao desfecho do conflito. Não é fácil aceitar que, neste contexto, o canto satírico, no centro político, tivesse a inocência do riso estéril ${ }^{7}$. Nem sequer é fácil aceitar que os quatro autores nele envolvidos não estivessem empenhados em encontrar um rumo para os próprios destinos na encruzilhada política e militar que teriam pela frente. Preocupados com os riscos, mas concentrados nas oportunidades que situações de mudança e necessidade podem criar. E se o canto que compõem é politicamente empenhado, não deixará certamente de refletir os planos que então poderiam ter para tal rumo.

\section{Local e datação da sátira}

Naturalmente, a consideração de tal contexto depende do tempo e local depreendido para a composição deste conjunto de cantigas. Os estudiosos não são especialmente claros a este propósito; no entanto, tendem a considerar a composição do conjunto fora de Portugal, no círculo do príncipe castelhano que haveria de ser Alfonso X; entre 1245 e 1248.

R. Oliveira é o mais preciso a propósito da cantiga Don Estevan diz que desamor, de Airas Peres Vuitorom, cuja composição situa entre 1245 e março de 1247. Deduz também que o autor a terá criado em Portugal ( $\ll$ Do verso 3 retira-se

7 R. Oliveira chama-lhe «uma excepção, uma espécie de momento de descontracção ou relaxamento entre sessões que se orientaram sobretudo para o comentário crítico dos acontecimentos políticos que decorriam no reino vizinho» (2006: 240, 241). 
igualmente a indicação de que Vuitorom se encontraria ainda em Portugal» (OLIVEIRA 2006: 237), na dependência da presença do infante castelhano no reino português. No entanto, ao concluir as suas reflexões sobre o conjunto de cantigas dedicadas a «Don Estevan» remata: «Caso se confirme o perfil desenhado para D. Estêvão, poderemos concluir que a produção satírica que se desenvolveu junto do infante castelhano [..]» (ibidem, p. 240). Tal afirmação deixa-nos na dúvida sobre se R. Oliveira considera a composição do ciclo em Portugal aquando da incursão de Alfonso, o que restringiria o período de composição ao segmento de tempo entre dezembro de 1246 e março de 1247, ou se considera que as cantigas foram compostas na corte castelhana. Em 1994, o historiador parecia no entanto inclinado para esta última possibilidade: «As sátiras a D. Estêvão, personagem visada também por João Soares Coelho, Airas Peres Vuitorom e Mem Rodrigues Tenoiro, e a referência que lhe faz Pero Garcia Burgalês, trovador activo em Castela na década de quarenta do século XIII, asseguram-nos que Rui Queimado terá passado igualmente pela corte castelhana durante o mesmo período» (OLIVEIRA 1994: 435).

Em comentário a esta cantiga, em CMGP, esclarece-se o entendimento da situação deste modo: «a composição deve ter sido composta, pois, na Primavera de 1247 , no momento em que D. Sancho II, quase derrotado, acompanha a hoste do príncipe D. Afonso (futuro Afonso X, vindo em seu auxílio) e se refugia em Castela, numa tentativa inglória de reunir forças contra seu irmão». Na nota ao texto Don Estevan fez sa partiçon, especifica-se a datação do conjunto de cantigas para um único ano: 1247. Esta opinião não é, no entanto, fundamentada.

Os editores de Roi Queimado têm a respeito da data e do local de composição do conjunto de cantigas uma posição bastante clara, embora esta abranja o que consideram a presença conjunta dos quatro trovadores no mesmo local e no mesmo tempo: «nella corte di Castiglia tra ca. il 1245 e il 1250» (LORENZO GRADÍN e MARCENARO 2010: 10).

Em resumo, embora os estudiosos tendam a expressar uma opinião relativamente vaga sobre a data e local de composição destas cantigas, parecem inclinar-se para um local distante dos acontecimentos e uma data próxima deles: Castela e os anos da guerra. Esta conjetura obriga-nos a ponderar a questão da relação da sátira com o seu público, necessariamente diferente da relação que existe entre uma peça literária de temática universal com os seus públicos.

Ao contrário de uma cantiga sobre o sofrimento de amor, por exemplo, cujos públicos em múltiplos espaços e tempos podem encontrar sentido ou sentidos para o universal ali desenvolvido, as cantigas satíricas são, por assim dizer, «deíticas». Têm com o tempo e o espaço uma relação que os implica e os denuncia. Podendo (teoricamente) ser compostas longe, não faz sentido que tenham sido apresentadas a um público distante dos acontecimentos. A performance, a infor- 
mação que o público tem, as chaves interpretativas que o público domina, e que o trovador sabe serem dominadas pelo público, condicionam necessariamente a composição da sátira. Talvez sobretudo, condiciona-a o interesse do público nos factos visados, decorrente de um envolvimento maior ou menor. Mesmo que a sátira não pretenda fazer rir, mesmo que apenas pretenda atingir, ela depende sempre do público para o conseguir. E se o público não conhecer figuras nem acontecimentos, se o público não se importar com eles, ou se simplesmente estiver mais (pre)ocupado com outros; se não estiver suficientemente envolvido e próximo, a sátira não produzirá os efeitos que a justificam. Por isso, a sátira, na sua relação com o público a que é dirigida, é ela própria um elemento indicador de tempo e espaço de composição. A questão, neste caso, passa portanto a ser não só onde poderão ter-se cruzado os quatro autores envolvidos, mas onde e quando estava o público que deu sentido à sátira a «Don Estêvão». A determinação deste aspeto implica conclusões sobre o tempo e o espaço em que se cruzaram os quatro autores. Não creio que este aspeto tenha sido considerado pelos estudiosos que localizaram em Castela a criação destas cantigas. 



\section{Algumas conclusões}

As últimas palavras deste estudo hão de ser de reflexão sobre o que nele pôde abrir caminho para um conhecimento antes inalcançado.

Editar criticamente, com o objetivo de nos aproximarmos do texto concebido pelo autor, eliminando, com a devida fundamentação, as deturpações decorrentes das vicissitudes da transmissão nada tem de novo. Assim como nada tem de novo a discussão de opções de editores anteriores e da argumentação por eles apresentada, com vista a uma cada vez mais solidamente ancorada fixação dos textos. Assim avançou sempre o conhecimento; assim continuará a avançar.

Mas o caso de «Don Estevan» não se teria resolvido, como de facto não se resolveu, se o objeto de estudo não se tivesse deslocado constantemente do texto para o contexto e deste novamente para o texto. Ou seja, se a fixação dos textos não tivesse sido apenas um dos objetivos, paralelo de outro: a compreensão da história entre cada um dos textos do conjunto; a compreensão do fio invisível que os une e se manifesta em alguns aspetos comuns. Este facto, devolve-nos inevitavelmente uma pergunta sobre as obrigações de uma edição crítica.

A resposta mais económica encontra os limites na fixação do texto, de que as notas ao texto são habitualmente a fundamentação e, consequentemente, a explicação. Idealmente, um comentário ajudará na recuperação do texto tal como pensado pelo autor, conforme objetivo de uma edição crítica. Mas, num caso como o do conjunto de cantigas satíricas contra «Don Estevan», o mesmo objetivo permanece fora do alcance, se mantivermos uma abordagem individual aos textos e se descurarmos a história que os motivou. É inevitável concluir, portanto, que os conjuntos satíricos da Lírica Galego-Portuguesa funcionam ou podem funcionar como um «macrotexto», cujas unidades estão interligadas e cujo entendimento depende do entendimento de todas as outras unidades. Já o tínhamos verificado no conjunto de textos em torno da Ama; confirmamo-lo neste. Naturalmente, o entendimento do «macrotexto» constituído pelo conjunto satírico reflete-se nas respostas que procuramos para a fixação dos textos, assim como nas notas aos textos que a fundamentam e nos comentários que os explicam. $\mathrm{O}$ que nos traz de volta à pergunta sobre as obrigações de uma edição crítica, que, num caso de «macrotexto» satírico haverão de ser acrescidas. Porque, neste caso, fixar textos individualmente, anotá-los e comentá-los não dá conta do que, não sendo estritamente de domínio autoral, é determinante para o entendimento do «macrotexto $\gg$. Do que sendo histórico, contextual, condicio- 
nante da criação, é determinante para o entendimento do «macrotexto». E, sem este entendimento, cumprirá a edição crítica as suas obrigações? Tenho consciência de que ao deixar implícita uma resposta negativa a esta pergunta estou a propor uma resposta mais exigente, no âmbito da edição crítica, para casos mais complexos, como os destes conjuntos satíricos, em que o texto se entretece com a história para produzir o referido «macrotexto». Não creio que nenhum outro tipo de edição possa produzir um resultado satisfatório, para um leitor que se deseje minimamente esclarecido.

O caso de «Don Estevan» também não se teria resolvido, é forçoso reconhecê-lo, a partir de uma abordagem concentrada no contexto, na história, ou seja, no esclarecimento de acontecimentos e figuras históricas. Os textos são chaves fundamentais para o entendimento, neste caso; e o estado em que alguns se encontravam impediam a leitura e o entendimento, quer individual quer do conjunto. Impunha-se uma abordagem efetivamente filológica, que alternasse, sempre que se impusesse, entre as vertentes da crítica textual, da história, da literatura e da língua.

O português dos cancioneiros, o português medieval, na verdade, permanece uma língua, em boa medida, por «cartografar». Razão pela qual a consulta dos glossários, que tanto ajuda, não é suficiente nem pode dispensar-nos de investigação para confirmar o acerto da informação contida em glossários mais antigos e mais recentes. Falta-nos ali, frequentemente, o contexto alargado fornecedor de informação tantas vezes indispensável. O conjunto satírico sobre «Don Estevan» não trouxe propriamente novidade a este respeito, mas a confirmação tem utilidade. Polissemia e amplitude semântica podem mudar perspetivas interpretativas, assim como a identificação de sentidos conhecidos ou que facilmente se deduzem, mas não estão sistematicamente registados.

Não foi igualmente novo o modo como, neste estudo, se esclareceu a semântica de algum léxico fundamental ao entendimento dos textos e do conjunto. Já no estudo da série de cantigas em torno da Ama recorri ao mesmo método de compulsar diversos textos para, observando os termos em múltiplos contextos, me aproximar dos sentidos, por vezes das diversas facetas de sentido, do vocabulário imprescindível à interpretação dos textos. Mas os resultados de novo obtidos com este método confirmam as afinidades entre a língua da lírica e a língua da prosa, especialmente, a prosa ligada à nobreza. Quem poderá estranhá-lo, considerando a influência da nobreza na criação da lírica? Quem poderá estranhá-lo, considerando que, embora em géneros literários diferentes, o perfil social e cultural dos que usam esta jovem língua é o mesmo? Retenhamos, em todo o caso, a evidente ligação, pela língua, entre lírica e prosa na Idade Média Portuguesa, especialmente a prosa ligada à nobreza. Esta conclusão não deixará de ser útil, sempre que os textos exijam esclarecimentos. 
O caso de «Don Estevan» convida igualmente a rever uma afirmação frequente na sequência da comparação entre a sátira provençal e a sátira galego-portuguesa: a de ser aquela mais abrangente, mais preocupada com valores ou questões de interesse geral, enquanto esta seria mais pessoal, concentrada nos pequenos defeitos de gente posta a jeito para fazer rir. A este retrato da sátira galego-portuguesa, o conjunto satírico contra «Don Estevan» deixou de corresponder. Embora especificamente dirigidas contra uma figura, as cantigas têm implicações mais abrangentes, assumindo um papel ativo nos acontecimentos políticos mais importantes do contexto que as provocou e recebeu. Também as sátiras em torno da Ama, mais do que um ataque ao trovador, foram uma discussão literária. Talvez não sejam casos isolados.

Precisamente por este papel e pelas tensões, alheias aos acontecimentos políticos, que foi possível determinar entre os trovadores, ou entre grupos de trovadores, teremos ainda de guardar para investigação futura que, do ponto de vista criativo, os autores deste conjunto, procuram distinguir-se ou identificar-se entre eles. A principal influência, assim como a pulsão para a competição, vem, portanto, do próprio grupo de trovadores galego-portugueses, que assim se batem por um reconhecimento poético, social e político de pares, público e, sobretudo, do poder que poderá eventualmente beneficiá-los. Não pelo canto, exclusivamente, mas pelos serviços vassálicos que incluiriam o canto e respetiva eficácia política. 


\section{Bibliografia}

Alarcão, Jorge de (2008) - Coimbra: a montagem do cenário urbano. Coimbra: Imprensa da Universidade de Coimbra

Albuquerque, Martim de e Nunes, Eduardo Borges, eds. (1988) - Ordenações Del-Rei Dom Duarte. Lisboa: Fundação Calouste Gulbenkian

Alvar, Carlos (1986) - «Las poésias de Pero Garcia d'Ambroa». Studi Mediolatini e Volgari. Vol. 32, p. 15-112.

Álvarez De la Granja, María (2005) - «Glosario de locucións adverbiais do galego medieval». Cuadernos de Fraseoloxía Galega. N..$^{7}$, p. 13-40.

Barreiro, M. C. (1985) - «O léxico dos miragres de Santiago. Memoria de licenciatura». In Ernesto González Seoane et al. - Dicionario de dicionarios do galego medieval. Disponível em:http://ilg.usc.gal/ddgm/ddd_pescuda.php?pescuda=aduzer\&tipo busca=lema.

Barros, Henrique da Gama (1945-1954) - História da Administração Pública em Portugal nos séculos XII $a$ XV. 2. ${ }^{\text {a }}$ ed., dir. por Torquato de Sousa Soares. Lisboa: Livraria Sá da Costa. 11 vols.

Beltrán, Vicenç (2000) - «Esteban Fernández de Castro y Fernán Díaz Escalho». Madrygal. N.o 3, p. 13-19.

Bíblia sagrada: tradução interconfessional do hebraico, do aramaico e do grego em português corrente. Trad. de António Augusto Tavares, et al. Lisboa: Difusora Bíblica, 1993.

BRAGA, Teófilo (1878) - Cancioneiro portuguez da Vaticana. Edição crítica restituida sobre o texto diplomático de Halle, acompanhada de um glossário e de uma introdução sobre os trovadores e cancioneiros portugueses. Lisboa: Imprensa Nacional.

Calderón Calderón, Manuel (1998) - «Las cantigas d’escarnho de Johan Velho de Pedrogaez». In I Congreso de Jóvenes Filólogos, A Coruña 1996 - Edición y anotación de textos: Actas. Coruña: Universidade da Coruña, Servizo de Publicacións, p. 123-133.

Cancioneiro da Biblioteca Nacional (Colocci-Brancuti). Reprodução facsimilada. Lisboa: Biblioteca Nacional; Imprensa Nacional - Casa da Moeda, 1982.

Cancioneiro português da Biblioteca Vaticana. Lisboa: Centro de Estudos Filológicos; Instituto de Alta Cultura, 1973.

Cantigas medievais galego-portuguesas (CMGP). Coord. de Graça Videira Lopes, et al. Lisboa: Instituto de Estudos Medievais, 2011. Disponível em: <http://cantigas.fcsh. unl.pt> . Consult. a 4 set. 2020.

Castelo Branco, Camilo (1858) - Carlota Ângela. Viana do Castelo: Aurora do Lima. 
Cepeda, Isabel Villares, ed. (1989) - Vidas e paixões dos Apóstolos. Compil. Bernardo de Brihuega: Lisboa: INIC. 2 vols.

Cintra, Luís Filipe Lindley (1990) - Crónica geral de Espanha de 1344. Lisboa: Imprensa Nacional Casa da Moeda. Vol. 4.

Cintra, Luís Filipe Lindley (1984) - Crónica geral de Espanha de 1344. Ed. facsimilada. Lisboa: Imprensa Nacional Casa da Moeda. Vol. 2, 3.

Cohen, Rip (2003) - 500 Cantigas de Amigo. Porto: Campo das Letras.

Cohen, Rip (1996) - «Dança jurídica». Colóquio Letras. N.o 142 (out.), p. 5-50.

Corominas, Joan e Pascual, José A. (2006-2007) - Diccionario critico etimológico castellano e hispánico. Madrid: Gredos.

CorreiA, Ângela (2017) - Ama: a importância de um nome no conhecimento sobre os trovadores medievais galego-portugueses. Lisboa: Bibliotrónica Portuguesa. Disponível em: <https://bibliotronicaportuguesa.pt/livro/ama-a-importancia-de-um-nome-noconhecimento-sobre-os-trovadores-galego-portugueses-angela-correia/ $>$.

CORREIA, Ângela (2016) - «A composição de cantigas de amor». In Colóquio Cancioneiro da Ajuda (1904-2004), Lisboa 2016 - À volta do Cancioneiro da Ajuda: atas. Lisboa: Imprensa Nacional - Casa da Moeda, p. 213-215.

CorreiA, Ângela (2011) - «A tenção entre Mem Rodrigues Tenoiro e Juião Bolseiro: cumplicidade na oposição». Românica. N. ${ }^{\circ}$ 20, p. 21-28.

Correia, Ângela (2003) - «Fragmento alojado. A cantiga de seguir de Fernam Rodrigues Redondo, Don Pedro est [o] cunhado del-Rei». Românica. N.o 12, p. 9-23.

Correia, Ângela (2001) - As cantigas de amor de D. Joam Soares Coelho e o «Ciclo da "Ama" »: edição e estudo. Dissertação de doutoramento apresentada à Faculdade de Letras da Universidade de Lisboa.

CORREIA, Ângela (1997a) - «A jura como prova na cantiga de amor galego-portuguesa». In Colóquio da Associação Hispânica de Literatura Medieval, Lisboa 1996 - O género do texto medieval. Lisboa: Cosmos, p. 55-69.

CorreiA, Ângela (1997b) - «Do refrão de Meendinho à escrita dos refrães nos cancioneiros ». In Congresso O Mar das Cantigas, Illa de San Simón 1998 - Atas. Santiago de Compostela: Xunta de Galicia, p. 267-290.

Costa, António Domingues de Sousa (1963) - Mestre Silvestre e mestre Vicente, juristas da contenda entre D. Afonso II e suas irmãs. Braga: Franciscana.

Costa, Avelino de Jesus da (1959) - O bispo D. Pedro e a organização da diocese de Braga. Coimbra: Faculdade de Letras da Universidade de Coimbra. 2 vols.

Costa, M. Gonçalves (1977) - História do bispado e cidade de Lamego. Vol. 1. Idade Média: a mitra e o município. Lamego: [s.n.].

Cunha, Maria Cristina (2001-2002) - «A organização da chancelaria arquiepiscopal de Braga (dos primódios a 1244) 》. Lusitania Sacra. S. 2, n. ${ }^{\circ}$ 13-14, p. 453-466.

Cunha, Rodrigo da (1634) - Primeira parte da Historia ecclesiastica dos Aacebispos de Braga, e dos santos, e varoes illustres, que florecerão neste arcebispado. Braga: Manuel Cardoso. Vol. 2. 
DuArte, Rei de Portugal (2012) - Leal conselheiro. Ed. coord. por João Dionísio et al. Lisboa: Universidade de Lisboa; Madison: Universidade de Wisconsin, 1437-1438. Disponível em: <http://digital.library.wisc.edu/1711.dl/IbrAmerTxt.LealConsel>.

D’Heur, Jean Marie (1984) - «Sur la généalogie des chansonniers portugais d’Ange Colocci». Boletim de Filologia. Vol. 29, p. 23-34.

D’Heur, Jean-Marie (1974) - «Sur la tradition manuscrite des chansonniers galiciens-portugais. Contribution à la Bibliographie Générale et au Corpus des troubadours». Arquivos do Centro Cultural Português. Vol. 8, p. 3-43.

Díaz de Bustamante, José Manuel (2007) - «Acerca de la Acomodación de Textos Latinos en la Lírica Medieval Hispánica: Revisión del Caso Gallego-Portugués». In V. Valcárcel Martínez y C. Pérez González, eds. - Poesía medieval (historia literaria y transmisión de textos). Burgos: Junta de Castilla y León, p. 219-247.

Dicionário Houaiss da língua portuguesa. Rio de Janeiro: Instituto António Houaiss, 2001.

Dionísıo, João (1992) - As cantigas de Fernan Soarez de Quinhones. Dissertação de mestrado apresentada à Faculdade de Letras da Universidade de Lisboa.

Donati, Cesarina (1979) - «Pero Goterres, cavaliere e trovatore». Studi Francesi e Portoghesi. Vol. 79, p. 67-92.

DURAND, Robert (1982) - Les campagnes portugaises entre Douro et tage aux XII ${ }^{e}$ et XIII siecles. Paris: Fundação Calouste Gulbenkian; Centro Cultural Português.

Eirín García, Leticia e Ferreiro, Manuel (2014) - O cancioneiro de Pero Mafaldo. Santiago de Compostela: Centro Ramón Piñeiro para a Investigación en Humanidades.

Fernandes, A. de Almeida (1991) - Taraucae monumenta historica: livro das doações de Tarouca. Braga: Câmara Municipal de Tarouca.

Fernandes, A. de Almeida (1970) - «A lealdade de bezerra pela beira muito anda (IV)». Esparsos de História (sécs. XII e XIII): com 143 documentos inéditos (73 do séc. XII). Porto: [s.n.], p. 105-136.

Fernandes, Hermenegildo (2010) - D. Sancho II. Lisboa: Temas e Debates.

FERrARI, Anna (1979) - «Formazione e struttura del canzoniere portoghese della Biblioteca Nazionale di Lisbona (Cod. 10 991: Colocci-Brancuti). Premesse codicologiche alla critica del testo ( materiali e note problematiche) >. Arquivos do Centro Cultural Português. Vol. 14, p. 27-142

FErreira, José de Azevedo, ed. (1989) - Flores de dereyto. Jacob de Junta. Braga: [s.n.].

Ferreira, José de Azevedo (1980) - Alphonse X, primeyra partida: edition et étude. Braga: Instituto Nacional de Investigação Científica.

Ferreiro, Manuel, dir. (2016-) - Universo cantigas: edición crítica da poesía medieval galego-portuguesa. Disponível em: <http://universocantigas.gal>. Consult. a 13 maio 2020.

Freixedo, Xosé Bieito Arias (2020) - «Trobar mal, malas cantigas, dizer mal, jugar de palabra... Reflexións sobre a (errada) identificación das cantigas de escarnio e mal dizer co concepto "jugar de palabra" do Título IX da Partida II». ArGaMed. Lírica Galego-Portuguesa. Lingua, Sociolingüistica e Pragmática. N.o 2, p. 11-36. 
GonÇAlves, Elsa (1993) - «Vasco Martins de Resende». In Lanciani, Giulia e Tavani, Giuseppe, ed. - Dicionário da literatura medieval galega e portuguesa. Lisboa: Caminho, p. 650.

Gonçalves, Elsa (1991) - Poesia de rei: três notas dionisinas. Lisboa: Cosmos.

GonÇALves, Elsa (1976) - «La tavola colocciana autori portughesi $\gg$. Arquivos do Centro Cultural Português. N.o 10, p. 387-448.

GonZÁLEZ GARCíA, Luis (2005) - «Castelán 'a hecho', galego 'a eito’: dúas locucións de diferente fortuna». Cuadernos de Fraseoloxía Galega. N.o 7, p. 91-117.

Grassotti, Hilda (1969) - Las instituciones feudo-vasalláticas en León y Castilla. Vol. 1. El Vasallaje. Spoleto: Centro Italiano di Studi Sull'Alto Medioevo.

Herculano, Alexandre (1915) - Historia de Portugal desde o começo da Monarchia até o fim do Reinado de Affonso III. 7. ${ }^{\mathrm{a}}$ ed. definitiva. Paris: Livrarias Aillaud; Lisboa: Bertrand; Rio de Janeiro, S. Paulo, Bello Horizonte: Livraria Francisco Alves. Vol. 4.

Herculano, Alexandre (1856) - Portugaliae Monumenta Historica. Vol. 1. Leges et Consuetudines. Olisipone: Typis Academicis.

Juarez Blanquer, Aurora e Rubio Flores, António (1991) - Partida segunda de Alfonso X el Sabio. Manuscrito 12794 de la B.N. Granada: Impredisur.

Juarez Blanquer, Aurora (1988) - Cancionero de Pero da Ponte. Granada: Ediciones tat.

Lanciani, Giulia e Tavani, Giuseppe (1995) - As cantigas de escarnio. Vigo: Edicións Xerais de Galicia.

LAPA, M. Rodrigues (1970a) - Cantigas d'escarnho e de mal dizer dos cancioneiros medievais galego-portugueses. 2. ${ }^{\text {a }}$ Ed. [Vigo]: Galaxia.

LAPA, M. Rodrigues (1970b) - Vocabulário galego-português. Tirado da ed. crítica das Cantigas d'escarnho e de mal dizer. [Vigo]: Galaxia.

LOPES, Graça Videira (2002) - Cantigas de escárnio e maldizer. Lisboa: Editorial Estampa.

Lorenzo Gradín, Pilar (2008) - Don Afonso Lopez de Baian. Cantigas. Alessandria: Edizioni dell'Orso.

Lorenzo Gradín, Pilar e Marcenaro, Simone (2010) - Il canzoniere del trovatore Roi Queimado. Alessandria: Edizioni dell'Orso.

Lorenzo, RAmon (1977) - La traduccion gallega de la Cronica General y de la Cronica de Castilla. Vol. 2. Glosario. Orense: Instituto de Etudios Oresanos «Padre Feijoo».

Machado, António de Sousa (1979) - Amarante medieval. Amarante: A. S. Machado.

Machado, Elza Pacheco e Machado, José Pedro (1949-1964) - Cancioneiro da Biblioteca Nacional antygo Colocci-Brancuti. Lisboa: Revista de Portugal. 8 vols.

Marcenaro, Simone (2015) - Afonso Anes do Coton. Cantigas. Roma: Carocci.

Marcenaro, Simone (2014) - L'equivocatio nella lirica galego-portoghese medievale. Alessandria: Ediziono dell'Orso.

Marcenaro, Simone (2012) - Pero Garcia Burgalês. Canzoniere: poesie d'amore, d'amico e di scherno. Alessandria: Edizioni dell'Orso. 
Marroni, Giovanna (1971) - «Sull' entità del canzoniere di Men Rodrigues Tenoiro». In Silvio Pellegrini - Studi di Filologia Romanza oferti a Silvio Pellegrini. Padova: Liviana Editrice, p. 267-277.

Martin, Georges (1997) - «Amour (une notion politique)». Annexes des Cahiers d'Études Hispaniques Médiévales Année. Vol. 11, Histoires de l'Espagne médiévale (historiographie, geste, romancero), p. 169-206

Matтoso, José (1992) - Portugal medieval. Novas interpretações. Lisboa: Imprensa Nacional - Casa da Moeda

Mattoso, José, ed. (1980) - Livro de linhagens do conde D. Pedro. Portugaliae Monumenta Historica. Nova série. Lisboa: Academia das Ciências. 2 vols.

Mattoso, José e SousA, Armindo de (1993) - História de Portugal. Vol. 2. A monarquia feudal (1096-1480). Lisboa: Círculo de Leitores

Menéndez Pidal, Ramón (1931) - Poema de Mio Cid. 3. ${ }^{a}$ ed. Madrid: Espasa-Calpe.

MerêA, Manuel Paulo (1929) - «Organização social e admnistração pública». In Damião Peres et al., ed. - História de Portugal. Barcelos: Portucalense. Vol. 2, p. 447-524.

Mettmann, Walter (1986-1989) - Alfonso X, el sabio. Cantigas de Santa Maria. Madrid: Castalia. 3 vols.

Miranda, José Carlos (2004) - Aurs Mesclatz ab Argen: sobre a primeira geração de trovadores galego-portugueses. Porto: Guarecer.

Monaci, Ernesto (1875) - Il canzoniere portoghese della Biblioteca Vaticana. Halle: Max Niemeyer.

Oliveira, António Resende de (2006) - «Distracções e cultura». In Leontina Ventura - D. Afonso III. Lisboa: Temas e Debates, p. 223-262.

Oliveira, António Resende de (1994) - Depois do espectáculo trovadoresco: a estrutura dos cancioneiros peninsulares e as recolhas dos séculos XIII e XIV. Lisboa: Colibri.

PAgani, Walter (1971) - Il canzoniere di Estevan da Guarda. Pisa: Pacini Editore.

PíEL, Joseph-Maria, ed. (1988) - A demanda do Santo Graal. Lisboa: Imprensa Nacional - Casa da Moeda. Ed. concluída por Irene Freire Nunes.

PizArro, José Augusto de Sotto Mayor (1997) - Linhagens medievais portuguesas: genealogias e estratégias (1279-1325). Dissertação de doutoramento em História da Idade Média, apresentada à Faculdade de Letras da Universidade do Porto. 3 vols.

Riquer, Martín de (1983) - Los trovadores: historia literaria y textos. Barcelona: Ariel.

RochA, Ana Rita (2013) - «A corte de D. Sancho II (1223-1248) ». Revista Portuguesa de História. N.o 44, p. 95-121.

Ron Fernández, Xosé Xabier (2018) - «Martin Codax: o nome. A onomástica na lírica trobadoresca». In Alexandre Rodríguez Guerra e Xosé Bieito Arias Freixedo, eds. The Vindel Parchment and Martin Codax = O Pergamiño Vindel e Martin Codax. Amsterdam: John Benjamins, p. 222-238. 
Silva, Rosa Virgínia Mattos e (1971) - A mais antiga versão portuguêsa dos quatro livros dos Diálogos de São Gregório: leitura crítica. Dissertação de doutoramento em Letras apresentada ao departamento de Linguística e Línguas Orientais da Faculdade de Filosofia, Letras e Ciências Humanas da Universidade de São Paulo. Vol. 2.

Sobral, Cristina (200o) - Adições portuguesas no Flos Sanctorum de 1513: estudo e edição crítica. Dissertação de doutoramento em Literatura Portuguesa apresentada à Faculdade de Letras da Universidade de Lisboa.

Sobral, Cristina (1997) - «A vida de S. Gonçalo de Amarante: hipóteses de datação e autoria». In VI Congreso Internacional de la Asociación Hispánica de Literatura Medieval, Alcalá 1995 - Atas. Espanha: Universidad de Alcalá. Vol. 2, p. 1449-1456.

SoDré, Paulo (2014) - «Arte de trovar e “Jugar de palabras” (Lei XXX do título IX da segunda de las siete partidas de Afonso X): aproximações preliminares ». Contexto. N.o 26 , p. 217-234.

SousA, Luís de, frei (1977) - Historia de S. Domingos. Introd. e revisão de M. Lopes de Almeida. Porto: Lello. Vol. 2. Terceira parte da História de S. Domingos particular...

TAVANI, Giuseppe (1967a) - «La tradizione manoscritta della lirica galego-portoghese $\gg$. Cultura Neolatina. A. 27, p. 41-94.

Tavani, Giuseppe (1967b) - Repertorio metrico della lirica galego-portoghese. Roma: Ateneo.

VAsconcelos, Carolina Michaëlis de (2004) - Glosas marginais ao Cancioneiro Medieval Português. Trad. Yara Fratescchi Vieira et alii. Coimbra: Universidade de Coimbra.

VAsconcelos, Carolina Michaëlis de (1990a) - Cancioneiro da Ajuda. Lisboa: Impensa Nacional-Casa da Moeda. 2 vols. Reimpressão da edição de Halle, 1904.

VAsconcelos, Carolina Michaëlis de (199ob) - «Glossario do Cancioneiro da Ajuda .

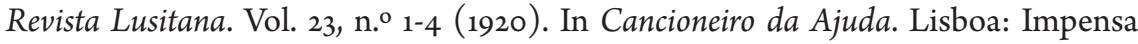
Nacional-Casa da Moeda. Vol. 1.

Ventura, Leontina (2006) - D. Afonso III. Lisboa: Círculo de Leitores.

Ventura, Leontina (1992) - A nobreza de corte de Afonso III. Dissertação de doutoramento em História da Idade Média apresentada à Faculdade de Letras da Universidade de Coimbra. 2 vols.

Ventura, Leontina e Oliveira António Resende de (2006-2011) - Chancelaria de D. Afonso III. Coimbra: Imprensa da Universidade de Coimbra. 3 vols.

ZILLI, Carmelo (1977) - Johan Baveca. Poesie. Bari: Adriatica Editrice. 


\section{Índice das sátiras editadas}

Don Estevan diz que desamor

Airas Peres Vuitorom

Don Estevan, eu eiri comi

Mem Rodrigues Tenoiro

Don Estevan, que lhi non gradecedes

Joam Soares Coelho

Don Estevan fez sa partiçon

JoAm SoAres Coelho

Don Estevan, en grand' entençon

Roi QueIMAdo

Don Estevan achei noutro dia

Mem Rodrigues Tenoiro

Don Estevan, tan de mal talan

Airas Peres Vuitorom

108

Don Marco, vej'eu muito queixar

Roi QueIMado

120 




\section{O outro nome de «Don Estevan» OITO SÁTIRAS TROVADORESCAS RELACIONADAS COM SANCHO II DE PORTUGAL}

Ângela Correia

Em 1244, Joam Viegas de Portocarreiro é eleito arcebispo de Braga, sob provável pressão de Sancho II, numa altura em que o isolamento político do Rei lhe exigia ação no sentido de garantir fidelidades. O trovador Joam Soares Coelho satiriza a eleição de um homem sem qualidades para o lugar. Propõe-lhe, por isso, que use outro nome na corte: o de um antecessor no arcebispado de Braga, largamente prestigiado: «Don Estevan» (Soares). A sátira ridiculariza o novo arcebispo de Braga, mas atinge também o Rei e as suas opções políticas.

Outros trovadores se juntaram depois à sátira política contra Joam Viegas de Portocarreiro, renomeado «Don Estevan»; por vezes, com objetivos diversos. Nestas sátiras, compostas numa época conturbada em que as circunstâncias mudaram com rapidez, nem sempre o que parece é. 